RAQUEL HARUMI IWASE

DISSERTAÇÃO DE MESTRADO

\title{
ASPECTOS CONTROVERTIDOS DA TRIBUTAÇÃO DO USO DE SOFTWARE
}

ORIENTADOR: PROF. DR. GERD WILLI ROTHMANN

FACULDADE DE DIREITO DA UNIVERSIDADE DE SÃO PAULO SÃO PAULO, JANEIRO DE 2013 
RAQUEL HARUMI IWASE

\section{ASPECTOS CONTROVERTIDOS DA TRIBUTAÇÃO DO USO DE SOFTWARE}

Dissertação apresentada à Banca Examinadora da Universidade de São Paulo, como exigência parcial para a obtenção do título de Mestre em Direito Econômico e Financeiro (subárea: Direito Tributário), sob a orientação do Professor Doutor Gerd Willi Rothmann. 
RAQUEL HARUMI IWASE

\section{ASPECTOS CONTROVERTIDOS DA TRIBUTAÇÃO DO USO DE SOFTWARE}

Aprovado em:

Banca Examinadora

Prof. Dr. Instituição:

Julgamento: Assinatura:

Prof. Dr. Instituição:

Julgamento: Assinatura:

Prof. Dr. Instituição:

Julgamento: Assinatura:

\section{SÃO PAULO}


Ao Renato, com amor, por compartilhar as páginas da vida comigo há tanto tempo, por fazer dos meus sonhos os seus próprios e pelas horas que lhe foram suprimidas para que este trabalho fosse concretizado.

$\grave{A}$ pequenina Yasmin que mesmo tão distante aquece o meu coração. 


\section{AGRADECIMENTOS}

Primeiramente agradeço a Deus a quem devo toda honra e toda glória por tornar os meus sonhos realidade e por ter sido o socorro bem presente que aplacou as minhas aflições, angústias e inseguranças em inúmeros momentos nesta caminhada.

Aos meus pais, Paulo e Vanda, pelo amor incondicional, pela devoção aos filhos, pelo apoio incessante e pela enorme paciência ao longo deste incrível desafio. Em especial, à minha mãe, verdadeira fonte de inspiração e exemplo de força e superação, cuja coragem e alegria de viver foram decisivas para sermos exitosos nos momentos de adversidades.

Ao Renato, pelo amor, companheirismo, carinho, apoio, paciência, cumplicidade e, principalmente, por segurar a minha mão quando eu mais preciso: muito obrigada!

Aos meus irmãos, Ana Paula e Jonathan, que estão ao meu lado em quaisquer circunstâncias.

Ao Professor Dr. Gerd, exemplo de sabedoria, entusiasmo, excelência acadêmica e profissional, por esta memorável oportunidade, pelas valiosas aulas na USP, conselhos e conversas dessas que abrem os horizontes e nos fazem enxergar coisas que antes não eram vistas e, acima de tudo, por ter acreditado em mim.

Os meus mais sinceros agradecimentos a todos os amigos e familiares que me apoiaram e torceram por mim no decorrer desta longa e desafiadora jornada. 


\section{RESUMO}

O objetivo do presente trabalho é analisar questões de elevada indagação jurídica quanto à tributação do uso do software no Brasil, levando-se em consideração os ditames previstos nas leis do software e de direito autoral, bem como o conteúdo decisório do acórdão proferido pelo STF nos autos do RE n 176.626-3, em especial a classificação tripartite de programas: (i) "de prateleira"; (ii) "sob encomenda"; e, (iii) híbrido.

Inicialmente, são analisadas questões importantes quanto ao sistema informático e a própria criação e composição de um programa de computador, passando pela sua natureza jurídica e pela proteção conferida pelo direito autoral, pondo em evidência as formas pelas quais são transferidos (parcial ou integralmente) os direitos patrimoniais de autor.

Na sequência, com base na Constituição Federal e na lei, analisa-se a incidência do ICMSoperação mercantil, dado que os programas "de prateleira" são comumente disponibilizados em mídias (disquetes, CDs, etc.) e postos à disposição de interessados em lojas de departamento. Para tanto, discorre-se acerca do regime jurídico-tributário do imposto e sobre os conceitos de "operações" e "mercadoria" com base na doutrina e na jurisprudência.

Considerando que o software elaborado "sob encomenda" e o híbrido ensejam questionamentos quanto à configuração de prestação de serviço, o arquétipo constitucional do ISSQN, inclusive na modalidade importação, é esmiuçado. A busca pela definição da expressão "serviços de qualquer natureza definidos em lei complementar" ganha destaque em razão de a $\operatorname{LC} n^{\circ} 116 / 03$ prever a incidência do ISS sobre ao "licenciamento ou cessão de direito de uso de programas de computação".

Por fim, são feitas breves considerações sobre outras controvérsias quanto à incidência do PIS-Importação, Cofins-Importação, CIDE e IRRF sobre os pagamentos remetidos ao exterior para a obtenção de licenças de uso de software.

Palavras-chave: ICMS. ISS. ISS-Importação. PIS-Importação. COFINS-Importação. CIDE. IRRF. Software. Cessão de Direitos. Licença de Uso. Prestação de Serviço. Mercadoria. 


\begin{abstract}
This study looks at certain highly relevant legal issues regarding taxation of software usage in Brazil, taking into account both software and copyright legislation as well as the decision in an appeal court ruling handed down by the STF in RE 176.626-3, particularly the three categories used to classify programs: (i) "off-the-shelf"; (ii) "tailor-made"; and (iii) "hybrid".
\end{abstract}

Initially, we will look at some of the main issues presented by IT systems and the creation and composition of computer programs, their standing in law and the copyright protections they enjoy, discussing the ways in which (partial or fully) copyrights can be transferred to third parties.

Based on the law and the Federal Constitution, we will then analyze the state tax on merchandise sales, as "off the shelf" programs are frequently made available on certain media (diskettes, CDs, etc.) and placed at the consumer's disposal in department stores. This will involve an assessment of the tax regime of ICMS as well as the concepts of "transactions" and "merchandise" in accordance with the doctrine and jurisprudence.

Considering that both "tailor made" and "hybrid" software raises issues about the way in which services are rendered, we will look in detail at the constitutional model of ISSQN and how it is imposed on imports of services. The phrase "services of any nature defined in supplementary law" is increasingly relevant and it will be scrutinized as the LC $\mathrm{n}^{\circ} 116 / 03$ states that ISS applies to "licensing or assignment of computer program user rights".

Finally, there will be a few remarks on other controversial issues related to PIS-Import, Cofins-Imports, CIDE and IRRF levied on the remittances of payments to a beneficiary resident or domiciled abroad to acquire software user licenses.

Keywords: ICMS. ISS. ISS-Imports. PIS-Imports. COFINS-Imports. CIDE. IRRF. Software. Assignment of Rights. User Licenses. Rendering Services. Merchandise. 


\section{ABREVIATURAS E SIGLAS}

ADCT Atos das Disposições Constitucionais Transitórias

ADIN Ação declaratória de Inconstitucionalidade

AgRg Agravo Regimental

CD Compact disc

CF Constituição Federal

CIDE Contribuição de Intervenção no Domínio Econômico

COFINS Contribuição para o Financiamento da Seguridade Social

CONFAZ Conselho Nacional de Política Fazendária

COSIT Coordenação Geral do Sistema de Tributação

CTN Código Tributário Nacional

DL Decreto-lei

EC Emenda Constitucional

GATT General Agreement on Tariffs and Trade

ICM Imposto sobre operações relativas à circulação de mercadorias

ICMS Imposto sobre operações relativas à circulação de mercadorias e sobre prestações de serviços de transporte interestadual e intermunicipal e de comunicação

INPI Instituto Nacional da Propriedade Industrial

IPI Imposto sobre produtos industrializados

IRRF Imposto sobre a renda retido na fonte

ISSQN Imposto sobre serviços de qualquer natureza

ITBI Imposto sobre a transmissão inter vivos de bens imóveis

ITCMD Imposto sobre transmissão causa mortis e doação

IVA Imposto sobre valor agregado

IVC Imposto sobre vendas e consignações

LC Lei Complementar

MF Ministério da Fazenda

Min. Ministro

MP Medida Provisória

OCDE Organização para a Cooperação e Desenvolvimento Econômico

OMC Organização Mundial do Comércio

OMPI Organização Mundial de Propriedade Intelectual 
PASEP Programa de Formação do Patrimônio do Servidor Público

PIS Programa de Integração Social

RAM Random access memory

RE Recurso Extraordinário

Rel. $\quad$ Relator

RESP Recurso Especial

RFB Receita Federal do Brasil

RICMS Regulamento do imposto sobre operações relativas à circulação de mercadorias e sobre prestações de serviços de transporte interestadual e intermunicipal e de comunicação

RIR Regulamento do Imposto de Renda

ROM Read only memory

SINIEF Sistema Nacional de Informações Econômicas e Fiscais

SRF Secretaria da Receita Federal

STF Supremo Tribunal Federal

STJ Superior Tribunal de Justiça

TRIPS Trade-Related Aspects of Intellectual Property Rights 


\section{SUMÁRIO}

1 INTRODUÇÃO

2 QUESTÕES FUNDAMENTAIS PARA A COMPREENSÃO DOS ASPECTOS CONTROVERTIDOS DA TRIBUTAÇÃO DO USO DE SOFTWARE.

2.1 O sistema informático e os seus componentes.................................................. 15

2.2 A proteção jurídica do software no âmbito internacional........................................ 20

2.3 O software no sistema jurídico brasileiro............................................................... 28

2.4 Breves considerações sobre a exploração econômica do software enquanto obra protegida pelo direito autoral

2.5 Licença de uso x Cessão de direitos.................................................................... 42

2.6 A licença de uso de programas de computador e suas variações............................ 46

2.7 O problema do enquadramento do software em classes....................................... 51

2.8 A classificação tripartite de espécies de software adotada pelo Supremo Tribunal

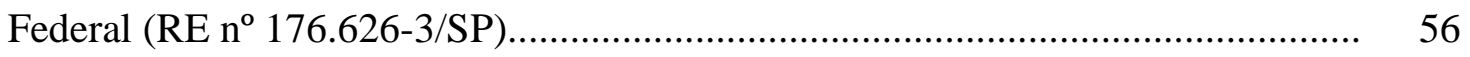

2.9 A diferença entre o software e o seu suporte material......................................... 58

2.10 A diferença entre software e conteúdo digital.................................................... 60

3 IMPOSTO SOBRE OPERAÇÕES RELATIVAS À CIRCULAÇÃO DE MERCADORIAS E SOBRE PRESTAÇÕES DE SERVIÇOS DE TRANSPORTE INTERESTADUAL E INTERMUNICIPAL E DE COMUNICAÇÃO.

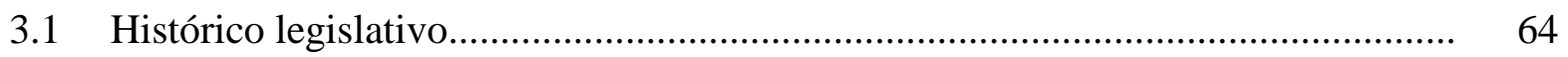

3.2 Regime jurídico-tributário e regra-matriz de incidência do ICMS (operação mercantil)......

3.3 Conceito de operações relativas à circulação de mercadorias.

3.4 Conceito de mercadorias.....

3.5 A mercadoria e o software (bem imaterial/intangível/incorpóreo)...

3.6 Impossibilidade jurídica do software e da respectiva licença de uso serem alcançados pelo ICMS.

3.7 Jurisprudência: uma análise crítica do conteúdo decisório firmado no RE $\mathrm{n}^{\mathrm{o}}$ $176.626-3$ 
3.8 Repercussões em razão da entrega do software por negócio eletrônico direto

4 IMPOSTO SOBRE SERVIÇOS DE QUALQUER NATUREZA

4.1 Histórico legislativo

4.2 Regime jurídico-tributário e regra-matriz de incidência tributária do ISSQN

4.3 Princípio da autonomia municipal.

4.4 Princípio da territorialidade

4.5 Lei complementar em matéria tributária..

4.6 Critério material: Prestar serviços de qualquer natureza.....

4.7 O conceito de serviço a partir do direito privado: uma obrigação de fazer

4.8 LC $\mathrm{n}^{\circ}$ 116/2003 - Item 1.05: Licenciamento ou cessão de direito de uso de programas de computação.

4.9 A questão do ISS sobre a licença de uso do software desenvolvido sob encomenda e do software híbrido.

4.10 A tributação dos serviços provenientes do exterior ou cuja prestação se tenha iniciado no exterior do País

5 OUTROS ASPECTOS CONTROVERTIDOS DA TRIBUTAÇÃO DO USO DE SOFTWARE - BREVES CONSIDERAÇÕES.

5.1 Contribuição para o Financiamento da Seguridade Social (COFINS) e Contribuição para os Programas de Integração Social e de Formação do Patrimônio do Servidor Público (PIS/PASEP) incidentes na importação.

5.2 Contribuição de Intervenção no Domínio Econômico instituída pela Lei $\mathrm{n}^{\mathrm{o}}$ $10.168 / 00$.

5.3 Imposto sobre a Renda Retido na Fonte - IRRF.

6 CONCLUSÕES. 


\section{INTRODUÇÃO}

Desde o final da década de 70 até o início da década de 90, o Brasil viveu anos de protecionismo na área da informática. Sob o argumento de tornar a indústria informática genuinamente nacional em uma indústria pioneira e inovadora, o Governo brasileiro instituiu uma atabalhoada reserva de mercado.

Neste período, o Brasil fechou suas portas para a tecnologia estrangeira acreditando que isso fomentaria uma indústria nacional competitiva. Contudo, o segmento de informática não atingiu os objetivos inicialmente propostos e a política adotada deixou como legado um atraso tecnológico que reverbera até os dias de hoje.

Tendo este histórico como pano de fundo, é fácil compreender as razões pelas quais o Brasil engatinha em matéria de desenvolvimento tecnológico. A globalização, a crescente movimentação de pessoas, bens e as mais variadas formas de negócios transfronteiriços que impulsionam as grandes economias de mercado comprovam quão equivocada foi a decisão dos governantes daquela época.

O tema relacionado com a evolução da informática e, portanto, da tecnologia brasileira vem ganhando cada vez mais destaque. Em 2007, o Conselho de Altos Estudos e Avaliação Tecnológica da Câmara dos Deputados, concluiu um extenso e rico trabalho dedicado à avaliação do mercado do software ${ }^{1}$ no Brasil, que contou com a colaboração de um grupo multidisciplinar de profissionais expoentes nas suas áreas de atuação.

Os trabalhos do grupo resultaram na publicação da obra $O$ Mercado de Software no Brasil: Problemas Institucionais e Fiscais $^{2}$. Note-se que as questões fiscais de tão importantes foram incluídas no título da obra.

Na sua introdução, o Deputado Arlindo Chinaglia ${ }^{3}$ é enfático ao concluir que a indústria brasileira do software ainda não conseguiu traduzir em números significativos a

1 O termo software, oriundo do idioma inglês, é inflexível em número e assim será utilizado em situações de plural.

2 LINS, Bernardo Felipe Estellita; LOPES, Cristiano Aguiar; NAZARENO, Cláudio (coord.), O Mercado de Software no Brasil: Problemas Institucionais e Fiscais, Brasília: Coordenação de Publicações da Câmara dos Deputados, 2007. 
sua participação no mercado interno, nem nas exportações. O então Deputado Marcondes Gadelha ${ }^{4}$, por sua vez, faz um apanhado dos entraves que a indústria do software enfrenta, pontuando as dificuldades em se compreender a natureza jurídica dos programas de computador e a indefinição dos tributos aplicáveis às transações que os envolvem.

É nesta toada que se enfrenta o desafio de compreender a natureza jurídica dos programas de computador e de identificar os tributos incidentes quando da obtenção de licenças de uso de software.

O Direito tutela a vida em sociedade, entretanto, o sistema jurídico brasileiro (positivista de origem romano-germânica) não se adequa automaticamente às novas realidades sociais e requer formais adaptações na legislação de tempos em tempos.

É por conta disso que no presente estudo são analisadas as materialidades dos tributos sempre partindo da Constituição Federal e, posteriormente, com base na lei e demais normas.

Assim sendo, o pacto federativo é fundamento basilar da República e ao seu lado caminha a estrita repartição de competências tributárias que, além de orientar a instituição de tributos, faz as vezes de limitação constitucional ao poder de tributar e proporciona segurança jurídica, permitindo a extração de conceitos constitucionais implícitos e pressupostos das materialidades eleitas pelo constituinte.

Tradicionalmente, as leis tributárias que gravam a compra e venda de mercadorias com o ICMS são elaboradas para alcançar bens dotados de materialidade, o que exige cuidadosa reflexão sobre a expressão "operações relativas à circulação de mercadorias" levando-se em consideração a figura da transferência jurídica e a imaterialidade imanente do software, mesmo em se tratando da modalidade "de prateleira".

Os programas elaborados "sob encomenda" e os "híbridos" dão margem a questionamentos de outra ordem por guardarem similitude com o fato gerador do ISSQN que é um tributo que intriga pela sua aparente singeleza e denso conteúdo. 
Quando se acreditava ter atingido o mais intrincado e recente problema que este imposto poderia causar, traduzido na guerra fiscal travada por Municípios que reputavam suas a competência pela tributação de determinado serviço, sobreveio a LC n ${ }^{\circ}$ 116/03 que não apenas reafirmou a competência do Município do local do estabelecimento prestador, como também reacendeu as discussões sobre os princípios da territorialidade, da autonomia municipal e também quanto à função da lei complementar em matéria tributária.

A LC $n^{\circ} 116 / 03$ também inovou ao prever a incidência do imposto municipal sobre a importação de serviços e por conta disso a hipótese de incidência do ISSQN requer seja revisitada em busca de respostas para indagações como: Em que consistem os serviços de qualquer natureza? Teria o Brasil aderido ao princípio do destino e autorizado a incidência do imposto sobre a importação de serviços? Teria o legislador complementar criado uma nova hipótese de incidência não prevista na Constituição? Teria o resultado do serviço sido eleito como o núcleo da nova materialidade do imposto?

É público e notório que os programas de computador mais utilizados no Brasil são estrangeiros. Em razão disso, outros tributos além do ICMS e do ISSQN merecem considerações, ainda que breves, pois incidem quer na importação de bens, quer na de serviços e, consoante se verá, guardam relação com as transações envolvendo programas de computador.

Em complementação ao todo acima exposto, deve-se considerar que os incontáveis avanços tecnológicos, a globalização, o fenômeno da internet e dos conteúdos digitais introduziram novas formas de relacionamento interpessoal e de negócios. Atualmente, os negócios eletrônicos, por exemplo, por meio dos quais bens e serviços são comprados e vendidos, assim como os mais variados bens imateriais são disponibilizados aos interessados por meio da transferência eletrônica de dados, impõem o desapego dos tradicionais paradigmas, pois só assim haverá um estudo livre de pré-conceitos e comprometido com a imparcialidade.

É assim que, sem a pretensão de esgotar o tema, serão analisados os aspectos controvertidos da tributação do uso de software. 


\section{QUESTÕES FUNDAMENTAIS PARA A COMPREENSÃO DOS ASPECTOS CONTROVERTIDOS DA TRIBUTAÇÃO DO USO DE SOFTWARE}

\subsection{O sistema informático e os seus componentes}

A informática é a ciência do processamento eletrônico de dados que proporciona resultados estruturados de forma lógica que são de extrema importância para o desenvolvimento de novos equipamentos, máquinas, inventos, além do aperfeiçoamento de serviços, trabalhos, projetos, dentre inúmeras outras funções. ${ }^{5}$

O processamento eletrônico de dados se perfaz em razão a conjugação de dois elementos: (a) o físico, ou hardware, palavra originária do idioma inglês, que pode ser considerado como um equipamento existente no mundo material, utilizado no acesso, armazenamento, processamento, movimentação, recuperação e transformação de informações; e (b) o imaterial, ou software, ou programa de computador, atualmente definido no art. $1^{\circ}$ da Lei $n^{\circ} 9.609 / 98$ (lei do software). ${ }^{6}$

Em razão da pujante inovação tecnológica dos dias atuais, o computador deixou de ser o principal equipamento que nos remete ao significado de hardware, assim como - e por decorrência - os programas variam na mesma proporção ante a relação de interdependência dos equipamentos que só funcionam em razão de determinado programa.

Portanto, ao longo do presente estudo, a despeito da utilização constante dos termos “computador" e "programa de computador", há que se ter em mente que outros equipamentos também integram a gênero hardware e são igualmente operados por programas, de modo que a compreensão dos citados termos há de ser em sentido amplo.

O computador é um bem material composto por um sistema central, responsável por gerenciar todas as atividades e que possui circuitos eletrônicos que executam funções específicas, sendo o principal deles a unidade central de processamento (CPU - central

5 Cf. BRANCHER, Paulo Marcos Rodrigues, Contratos de Software, Florianópolis: Visual Books, 2003, p. 9.

6 Cf. BRANCHER, Paulo Marcos Rodrigues, Contratos, op. cit., p. 9. 
processing unit). Entretanto, para que o computador interaja com o mundo exterior de uma forma que os usuários compreendam o que é transmitido pelo sistema central e para que este também compreenda as instruções dos usuários, são necessários equipamentos periféricos ${ }^{7}$ (tais como: modem $^{8}$, teclado, monitor, impressora, etc.). ${ }^{9}$

A CPU é composta de circuitos eletrônicos que são ativados por impulsos elétricos representados pelos números "zero" ou "1". A CPU reconhece "0" como indicativo de ausência de impulso e " 1 " como presença do impulso. ${ }^{10}$

À combinação dos números acima mencionados dá-se o nome de bits, termo em inglês para dígitos binários também conhecidos como "linguagem de máquina", que nas palavras de José de Oliveira Ascensão ${ }^{11}$ :

\begin{abstract}
"O computador atinge a sua complexidade através do maior despojamento possível da linguagem. A linguagem do computador assenta unicamente no sinal eletrônico. A combinação de sinais permite chegar a dois símbolos -1 e $0-$ representando 1 a presença de sinal, e 0 a ausência desse sinal. A linguagem do computador é assim uma linguagem binária, em que os únicos elementos perceptíveis pela máquina são 1 e o 0 . A máquina transforma-os em sinal eletrônico ou omissão de sinal. Todas as combinações possíveis exprimir-se-ão, portanto, sempre sob a forma de uma seriação de 1 e 0 . Num programa complexo, essa seriação será longuíssima: ocupará volumes inteiros."
\end{abstract}

O software, por sua vez, é definido por Bill Gates como um grupo de regras que dadas a uma máquina para instruí-la sobre como realizar determinadas tarefas. ${ }^{12}$

7 Marcos Wachowicz define periféricos da seguinte forma: "são os dispositivos de entrada e saída que trabalham em conjunto com o computador, quais sejam: dispositivo de entrada (input) do computador teclado, mouse, recursos de multimídia, scanners para a digitalização de imagens e leitura de código de barras, câmaras, filmadoras, leitores óticos, digitalizadores e microfones; dispositivos de saída (output) monitores, impressora; dispositivos de entrada e saída concomitantes - placas de rede (...)" (Revolução Tecnológica e Propriedade Intelectual, in Pimenta, Eduardo Salles (coord.), Direitos Autorais - Estudos em homenagem a Otávio Afonso dos Santos, São Paulo: RT, 2007, p. 233). De acordo com Roberto Chacon de Albuquerque, "os dispositivos de entrada convertem dados num formato que possa ser processado pela CPU; os dispositivos de saída convertem dados que foram processados pela CPU num formato que possa ser compreendido pelo usuário" (A Propriedade Informática, Campinas: Russell, 2006, p. 31). Por meio dos periféricos é possível inserir dados na CPU, os quais são armazenados na memória e posteriormente processados. Os dados processados podem seguir o caminho inverso, ou seja, depois de processados poderão ser salvos na memória e transferidos para dispositivos de saída do usuário do sistema.

8 Que por tradução livre significa modulador e demodulador de telecomunicações.

9 Cf. AlbUQUERQUE, Roberto Chacon de, A Propriedade Informática, Campinas: Russell, 2006, p. $28 / 32$.

10 Cf. ALBUQUERQUE, Roberto Chacon de, A Propriedade, op. cit., p. 32.

11 Direito Autoral, Rio de Janeiro: Renovar, 2007, p. 650.

12 Apud GONÇALVES, Renato Lacerda de Lima, A Tributação do Software no Brasil, São Paulo: Quartier Latin, 2005, p. 51 
Para Hugo Orrico Junior ${ }^{13}$, em palavras mais simples, programa de computador é o conjunto de instruções imateriais que dão utilidade a determinado meio físico e sem as quais torna-se imprestável.

O software é uma série de bits (dígitos binários) que funciona dentro da CPU (central processing unit ${ }^{14}$ ) como um conjunto de impulsos elétricos dispostos numa sequência preordenada, que se sucedem no computador para que ele execute tarefas definidas pelo programador. A CPU tem acesso ao programa de computador de acordo com sua posição na memória ${ }^{15}$, a partir da qual o programa é reproduzido e executado. Assim, o programa aciona e controla o funcionamento do hardware. ${ }^{16}$

O computador somente efetua as operações a que se destina se comandado por um programa $^{17}$. Essa interação dá ensejo ao sistema informático que na definição de Renato Borusso $^{18}$ é:

\begin{abstract}
"Um complexo unitário de máquinas com funções diferenciadas, com extraordinária capacidade de memorizar qualquer tipo de dado e, portanto, de incorporar o pensamento passado ou presente, com capacidade de operar em velocidade vertiginosa, cálculos, pesquisas (...) e realidades complexas que, por dimensão e quantidade, escapam da possibilidade de um controle humano e que, por consequência, se transforma numa inteligência artificial operativamente superior às próprias faculdades do homem que a criou.”
\end{abstract}

A fim de melhor compreender a participação e importância do software no sistema informático, não se pode deixar de mencionar os esclarecimentos dados por John G. Burch e Felix R. Strater, segundo os quais:

"O computador e equipamentos semelhantes podem ser divididos em três grandes partes, que são: (1) o processador central, (2) dispositivos periféricos ao

Pirataria de Software, São Paulo: MM Livros, 2004, p. 60.

4 Unidade central de processamento.

15 Roberto Chacon de Albuquerque elucida que são, basicamente, duas as espécies de memória, quais sejam a RAM e a ROM. A RAM - correspondente ao termo em inglês random access memory (memória de acesso aleatório) - é posta diretamente na principal placa de circuito integrado do computador, enquanto a $\mathrm{ROM}$ - read only memory (memória apenas de leitura) - é armazenada permanentemente. Segundo ele, a memória RAM pode ser tida como folhas de papel nas quais é possível escrever palavras, apagá-las e reescrever outras, enquanto a ROM pode ser equiparada a um livro com palavras indelevelmente impressas. Tanto a memória RAM como a ROM são ligadas por um conjunto de circuitos à CPU ( $A$ Propriedade, ob. cit., p. 30).

16 Cf. AlBUQUERQUE, Roberto Chacon de, A Propriedade, op. cit., p.32.

17 Cf. BRANCHER, Paulo Marcos Rodrigues, Contratos, op. cit., p. 10.

18 Apud BRANCHER, Paulo Marcos Rodrigues, Contratos, op. cit., p. 10. 
processador e (3) dispositivos de comunicação de dados que conectam dispositivos periféricos do processador central (...).

$\mathrm{O}$ coração de qualquer configuração de computador é a unidade central de processamento, ou CPU. (...)

O processador central é realmente o 'computador' em uma configuração de computador, e todas as configurações de computador fazem cinco funções básicas, que são:

1. Input. Os dados que serão objeto de operação e as instruções sobre o método de operação são disponibilizados à unidade central de processamento em uma forma que possa utilizar a mídia de entrada.

2. Armazenagem primária. A partir da mídia de entrada, os dados e instruções são inseridos na seção principal de armazenamento do processador central. Outras mídias de armazenagem (tais como fita magnética, disco magnético) são considerados auxiliares à armazenagem primária.

3. Aritmética-lógica. O processador manipula dados de acordo com o algoritmo de instruções (aqui está a essência de praticamente tudo que precisamos saber sobre software). Estas manipulações são realizadas na seção aritmética-lógica, uma operação de cada vez, com resultados intermediários sendo colocados de volta na Armazenagem primária. A seção aritmética-lógica realiza adição, subtração, multiplicação, divisão, e certas operações lógicas tais como comparar a magnitude de dois números.

4. Controles. Controles são necessários dentro de um sistema de computador para: (1) indicar à mídia de entrada quais dados inserir na armazenagem primária e quando inseri-los; (2) indicar à seção de armazenagem primária onde inserir estes dados; (3) indicar à seção aritmética-lógica quais operações realizar, onde os dados se encontram e onde colocar os resultados; (4) indicar quais dispositivos de arquivo acessar e quais dados acessar; (5) indicar em qual mídia de saída os resultados devem ser escritos.

5. Output. Esta função refere-se à saída de resultados dos dados processados dentro do processador central. Este resultado final é escrito em qualquer mídia de saída ou em uma combinação delas."19

Qualquer programa de computador é executado pela unidade central de processamento, que é o centro de controle responsável pela execução das operações lógicas e aritméticas do equipamento. O computador, componente material, é um equipamento inerte sem um programa (componente imaterial de um sistema informático). ${ }^{20}$

O controle responsável pela execução das operações lógicas é o sistema operacional, que pode ser considerado o principal programa de um computador e é ele que comanda e harmoniza o hardware e os outros programas aplicativos. ${ }^{21}$

Um programa de computador pode ser descrito como a expressão de uma ideia esboçada num fluxograma ${ }^{22}$ ou num algoritmo ${ }^{23}$; como uma série de instruções em

19 Apud GONÇALVES, Renato Lacerda de Lima, A Tributação, op. cit., p. 45/46.

20 Cf. ALBUQUERQUE, Roberto Chacon de, A Propriedade, op. cit., p. 31.

21 Cf. GONÇALVES, Renato Lacerda de Lima, A Tributação, op. cit., p. 48.

22 Descreve a lógica do tratamento de dados e é composto por desenhos e símbolos gráficos.

23 De acordo com Roberto Chacon de Albuquerque, o algoritmo "pode ser entendido como uma representação de cunho matemático do processo lógico que é a base do programa; como um método de 
linguagem de máquina ou em linguagem evoluída; como um processo técnico de controle do funcionamento de um computador; como um acessório utilizado no sistema informático; como um conjunto conciso de instruções que controlam o hardware; ou, até, como uma estrutura intelectual do processamento eletrônico de dados. ${ }^{24}$

Segundo Roberto Chacon de Albuquerque, antes de atingir a sua forma definitiva, o programa atravessa diversas etapas de desenvolvimento, que podem ser assim descritas:

\begin{abstract}
"A programação não consiste apenas na operação de codificar as instruções nessa linguagem assimilável pelo computador, chamada 'linguagem de máquina', porém, mais genericamente, o processo que decompõe problemas numa série bem definida de operações elementares. Esse processo pode ser representado sob uma forma gráfica - fluxogramas (e não gráfica, linguística algoritmos).

A primeira etapa de desenvolvimento de um programa de computador consiste numa análise preliminar do problema a ser tratado. Cabe fazer um levantamento de todas as etapas e decisões a serem tomadas, elaborando uma síntese do que deve ser feito. Essa etapa é mais complexa do que pode parecer à primeira vista. Para estabelecer o esquema geral das operações a realizar, o analista de sistemas deve repensar completamente a questão. Ao final dessa análise, é elaborado um fluxograma que descreve a lógica do tratamento de dados, mas sem entrar em muitos detalhes. Numa segunda etapa, o programador, partindo dos resultados delineados pelo analista de sistemas, pormenoriza o fluxograma, compondo o esqueleto do programa. Em seguida, será necessário redigir a sequência de instruções que descreve as tarefas a serem executadas. O computador executa apenas as instruções que lhe forem fornecidas.

Ao invés de ser representado sob essa forma gráfica, o programa pode ser objeto de uma representação algorítmica. O algoritmo pode ser entendido como uma representação de cunho matemático do processo lógico que é a base do programa; como um método de resolução do problema expresso por fórmulas matemáticas; ou como um procedimento para a solução de uma tarefa., ${ }^{25}$
\end{abstract}

O algoritmo representa o início do desenvolvimento do software. A partir dele, passa-se a ao procedimento que viabiliza a comunicação entre o programador e a máquina, ou seja, são elaborados códigos inteligíveis para o ser humano e que representem comandos de programação. ${ }^{26}$

Assim, é no código-fonte onde estão a estrutura do programa e os comandos para o hardware alcançar o resultado pretendido. O código-fonte é a expressão da ideia do algoritmo, em uma linguagem humana, evidentemente dentro dos limites do conhecimento

resolução do problema expresso por fórmulas matemáticas; ou como um procedimento para a solução de uma tarefa" (A Propriedade, op. cit., p. 33).

24 Cf. ALBUQUERQUE, Roberto Chacon de, A Propriedade, op. cit., p. 36.

25 A Propriedade, op. cit., p. 32/33.

26 Cf. BRANCHER, Paulo Marcos Rodrigues, Contratos, op. cit., p. 17. 
técnico de programação. Não é uma linguagem que leigos compreendem, mas não é uma linguagem somente compreensível pelos computadores. ${ }^{27}$

Pode-se dizer que o software é finalmente elaborado quando o código-fonte está escrito e, por assim dizer, trata-se de material importantíssimo que permite conhecer a sua estrutura, os seus comandos, ter acesso à tecnologia utilizada, bem como reproduzi-lo, alterá-lo, ampliá-lo, impor restrições, reparar erros, etc. ${ }^{28}$

Entretanto, apenas o algoritmo e o código-fonte não bastam para que o programa possa interagir com o hardware. É preciso que as informações contidas no código-fonte sejam vertidas para uma linguagem que somente o equipamento entenda, que é o códigoobjeto. Assim, após a transformação do programa de código-fonte em código-objeto, o conteúdo da programação não é mais compreensível pelo homem médio. ${ }^{29}$

Portanto, o software é um texto redigido de uma maneira que as instruções contidas no algoritmo, no código-fonte e no código-objeto são compreendidas pelo hardware. ${ }^{30}$

\subsection{A proteção jurídica do software no âmbito internacional}

O problema do adequado enquadramento do software ou, melhor dizendo, da definição da sua natureza jurídica, objeto de longas controvérsias ${ }^{31}$ doutrinárias e jurisprudenciais, foi superado pela maioria dos países que, com base na Convenção de Berna $^{32}$, equiparam os programas de computador às obras literárias e, por conseguinte, recebem a tutela do direito do autor. ${ }^{33}$

27 Cf. BRANCHER, Paulo Marcos Rodrigues, Contratos, op. cit., p. 18.

28 Cf. BRANCHER, Paulo Marcos Rodrigues, Contratos, op. cit., p. 18.

29 Cf. BRANCHER, Paulo Marcos Rodrigues, Contratos, op. cit., p. 18/ 19.

30 Cf. ALBUQUERQUE, Roberto Chacon de, A Propriedade, op. cit., p. 33.

31 Muito se discutiu sobre o software ser tutelado pelo direito do autor ou pelo direito da propriedade industrial ou, ainda, por uma modalidade sui generis em razão do seu caráter utilitário, que permite o acionamento de máquinas e o manejo eletrônico de dados. Marcos Wachowicz assevera que "os primados clássicos da propriedade intelectual assentam a diferença entre o direito autoral e a propriedade industrial como sendo: quanto ao primeiro, a proteção e tutela da comunicação, das ideias, da beleza e dos sentimentos do gênero humano; e quanto ao segundo, o sentido prático e transformador da matéria e da tecnologia que se pretende proteger, criando-se o direito de exploração exclusiva da mesma" (Revolução Tecnológica e Propriedade Intelectual, in Pimenta, Eduardo Salles (coord.), Direitos Autorais - Estudos em homenagem a Otávio Afonso dos Santos, São Paulo: RT, 2007, p. 239).

32 Segundo José Carlos Costa Netto, a Convenção de Berna "consagrou de forma ampla e definitiva os direitos do autor em todo o mundo" (Direito Autoral no Brasil, São Paulo: FDT, 2008, p. 58).

33 Cf. PAESANI, Liliana Minardi, Direito de Informática, São Paulo: Atlas, 1999, p. 25. 
Isso porque, o programa de computador é um bem móvel vulnerável, passível de ser copiado com facilidade, de modo que a sua proteção sempre foi e sempre será indispensável para o combate da pirataria, bem como para controlar a transferência de tecnologia por meio das redes de transmissão de dados que permitem o envio/recebimento de dados transfronteiriços.

Ademais, consoante afirma Gisele Ferreira de Araújo ${ }^{34}$, a proteção dos programas de computador pelo direito autoral também passou a ser necessária para assegurar garantias de proteção jurídica à criação, à produção e à exploração de obras, ante ao fato do desenvolvimento tecnológico ter diversificado as formas de exploração econômica.

Aliás, a transnacionalidade é característica marcante do direito autoral, sendo a Convenção de Berna de 1886 o marco da tendência de amenizar as relações internacionais neste campo da atividade humana. ${ }^{35}$

Muito se discutiu sobre o software ser tutelado pelo direito do autor ou pelo direito da propriedade industrial ou, ainda, por uma modalidade sui generis em razão do seu caráter utilitário, que permite o acionamento de máquinas e o processamento eletrônico de dados. Neste sentido, Marcos Wachowicz assevera que "os primados clássicos da propriedade intelectual assentam a diferença entre o direito autoral e a propriedade industrial como sendo: quanto ao primeiro, a proteção e tutela da comunicação, das ideias, da beleza e dos sentimentos do gênero humano; e quanto ao segundo, o sentido prático e transformador da matéria e da tecnologia que se pretende proteger, criando-se o direito de exploração exclusiva da mesma". ${ }^{36}$

Como bem observam Carlos Alberto Bittar e Carlos Alberto Bittar Filho ${ }^{37}$, em toda obra intelectual existe o inexorável aproveitamento do acervo comum da humanidade, de

34 A Tutela Internacional do Direito do Autor, in Pimenta, Eduardo Salles (coord.), Direitos Autorais Estudos em homenagem a Otávio Afonso dos Santos, São Paulo: RT, 2007, p. 130.

35 Cf. ARAÚJO, Gisele Ferreira, A Tutela Internacional do Direito do Autor, in Pimenta, Eduardo Salles (coord.), Direitos Autorais - Estudos em homenagem a Otávio Afonso dos Santos, São Paulo: RT, 2007 , p. 126.

36 Revolução Tecnológica e Propriedade Intelectual, in Pimenta, Eduardo Salles (coord.), Direitos Autorais - Estudos em homenagem a Otávio Afonso dos Santos, São Paulo: RT, 2007, p. 239.

37 Tutela dos Direitos da Personalidade e dos Direitos Autorais nas Atividades Empresariais, São Paulo: RT, 2002, p. 173. 
que mesmo inconscientemente, o autor se vale, em todo e qualquer gênero e que por conta disso o conceito de originalidade se reveste de sentido relativo.

Segundo os citados doutrinadores, esse é o ponto que diferencia os direitos autorais dos direitos industriais, prevalecendo, nos últimos, a novidade em sentido absoluto, exatamente em função dos princípios e regras próprias do setor.

É importante examinar os critérios adotados para a proteção do direito de autor vinculados à referida Convenção, não apenas porque o Brasil ${ }^{38}$ os assimilou em seu direito interno, consoante será abordado neste trabalho, como também por conferir primazia aos acordos, convenções e tratados ratificados sobre esta matéria. ${ }^{39}$

A Convenção de Berna foi referendada pelo Congresso Nacional (Decreto Legislativo $\mathrm{n}^{\circ}$ 94/74) e promulgada pelo Decreto $\mathrm{n}^{\circ} 75.699 / 75$, cujo art. $2^{\circ}-1$ dispõe que $o s$ termos "obras literárias e artísticas" abrangem todas as produções do domínio literário, científico e artístico, qualquer que seja o modo ou a forma de expressão, tais como os livros, brochuras e outros escritos; as conferências, alocuções, sermões e outras obras da mesma natureza; as obras dramáticas ou dramático-musicais; as obras coreográficas e as pantomimas; as composições musicais, com ou sem palavras; as obras cinematográficas e as expressas por processo análogo ao da cinematografia; as obras de desenho, de pintura, de arquitetura, de escultura, de gravura e de litografia; as obras fotográficas e as expressas por processo análogo ao da fotografia; as obras de arte aplicada; as ilustrações e os mapas geográficos; os projetos, esboços e obras plásticas relativos à geografia, à topografia, à arquitetura ou às ciências.

Plínio Cabral, em breves palavras, faz um resumo da Convenção de Berna, nos seguintes termos:

38 José Carlos da Costa Netto relembra que o Brasil, de forma precursora, aderiu originariamente à Convenção de Berna em 9.2.1922, seis anos antes do Canadá, que aderiu em 1928, e mais de quatro décadas antes dos demais países do continente americano; Argentina, Uruguai e México somente aderiram em 1967, o Chile em 1970; seguindo-se os outros países do nosso continente. Os Estados Unidos da América, mentores da Convenção Universal de 1952, somente aderiram à Convenção de Berna em 1.3.1989, 67 anos depois do Brasil (Direito Autoral, op. cit., p. 59).

39 Cf. ARAÚJO, Gisele Ferreira, A Tutela Internacional, op. cit., p. 126. 
"Estabelece o que é obra literária e artística: todas as produções no campo literário e artístico, científico e artístico, qualquer que seja o modo ou forma de expressão;

Apresenta os critérios para a proteção autoral: protege-se a manifestação concreta do espírito criador, ou seja, aquilo que se materializa;

Define o que é obra publicada: 'aquelas que foram editadas com o consentimento do autor, qualquer que seja o modo de fabricação dos exemplares, sempre que a quantidade posta à disposição do público satisfaça razoavelmente suas necessidades';

Declara que o 'gozo e exercício desses direitos não estarão subordinados a nenhuma formalidade'; o autor é identificado perante os tribunais pelo seu nome aposto à obra, mesmo que seja um pseudônimo; ele está livre do controle governamental;

Fixa e define o país de origem: 'aquele em que a obra foi publicada pela primeira vez';

Assegura o direito de adaptação, tradução autorizada, os direitos sobre obras dramáticas e dramático-musicais;

Fixa o prazo de vigência dos direitos do autor após sua morte: 50 anos. Mas garante aos países signatários da Convenção o direito de aumentar esse prazo;

Divide, claramente, os direitos de autor em patrimoniais e morais, estes irrenunciáveis e inalienáveis, mesmo quando o autor cede definitivamente sua obra para exploração de terceiros;

Garante o direito à paternidade da obra e o privilégio de autor de impedir modificações de qualquer natureza;

Fixa as limitações aos direitos do autor: cópias sem fins de lucro, citações, notícias de imprensa, divulgação dos fatos e informações gerais são livres;

Assegura o chamado 'direito de suíte', ou seja, a participação do autor nos lucros da eventual revenda de sua obra." 40

Gisele Ferreira de Araújo pondera que a Convenção de Berna passou por mais quatro modificações depois de 1914, quais sejam, os Atos de Roma de 1928, de Bruxelas de 1948, de Estocolmo e os Protocolos Integrativos ambos de 1967, quando se definiu a Organização Mundial para a Propriedade Intelectual $\left(\mathrm{OMPI}^{41}\right)$ e, finalmente, a revisão de Paris de 1971, acompanhada de anexo. Segundo ela:

\footnotetext{
"Porém, a Convenção de Berna destaca-se por seu caráter altamente protetivo, constituindo-se no mais importante instrumento de proteção internacional aos direitos autorais por uma identidade quase que absoluta com os direitos da personalidade humana, o que a torna uma das mais aderidas e com maior amplitude de ação em âmbito internacional.

Em seu sistema são congregados países europeus, americanos, asiáticos, que a têm como principal expediente de proteção à cultura e valores humanos essenciais.

A Convenção de Berna compreende 38 artigos e um Anexo contendo regras de caráter material e administrativo, distribuídas em preâmbulo, disposições de direito material, disposições administrativas e cláusulas finais. As disposições de fundo ou de direito material versam sobre normas convencionais e normas de conflito."
}

40 A Nova Lei de Direitos Autorais - Comentários, São Paulo: Harbra, 2003, p. 7.

41 Na língua inglesa é conhecida como World Intellectual Property Organization - WIPO.

42 A Tutela Internacional, op. cit., p. 126. 
Entretanto, é importante mencionar que a referida Convenção nada dispõe sobre software, mas apenas sobre obras literárias e artísticas.

Em que pese a importância da Convenção de Berna, a regulamentação mais importante para proteção de obras intelectuais em âmbito internacional foi realizada pela OMPI, com a celebração de dois tratados, quais sejam, o Tratado sobre Direito de Autor da Organização Mundial de Propriedade Intelectual (em inglês, Copyright Treaty-WTC) e o Tratado sobre Interpretações e Fonogramas da OMPI (em inglês, Performances and Phonograms Treaty-WPPT).

O Tratado sobre o Direito de Autor, supramencionado, ganhou notoriedade não só pela sua inovação, mas também por incluir os programas de computador na categoria de obras intelectuais, o que é confirmado por José Carlos Costa Netto:

\begin{abstract}
"Os países integrantes da União de Berna, tendo em vista que o texto da Convenção - mesmo com a revisão (1971) e a modificação (1979) - necessitava da introdução de novas normas internacionais (e classificação de interpretação de certas normas vigentes) para proporcionar soluções econômicas, sociais, culturais e tecnológicas - reconhecendo, neste aspecto, o profundo impacto trazido pelo desenvolvimento e pela convergência das tecnologias de informação e comunicação na criação e utilização de obras intelectuais -, reuniram-se, em Genebra, em Conferência Diplomática para aprovar, em 20/12/1996, o 'Tratado da OMPI sobre Direito de Autor'.

Integrado por 25 artigos, estabelecem normas principalmente nos seguintes itens: programas de computador (art. $4^{\circ}$ ), compilações - ou bases - de dados (art. $5^{\circ}$ ), direito de distribuição, de locação e comunicação ao público (arts. $6^{\circ}, 7^{\circ}$ e $8^{\circ}$ ), limitações e exceções (art. 10), e obrigações relativas às medidas tecnológicas (art. 11)."43
\end{abstract}

Assim, ao inserir o software na categoria jurídica das obras intelectuais, a OMPI estabeleceu um conjunto de dispositivos assecuratórios dos interesses dos autores de programas de computador. ${ }^{44}$

Atendo-nos ao Tratado sobre Direito de Autor, que é o que guarda relação com o presente estudo (e por isso não vamos abordar o Tratado sobre Interpretações e Fonogramas da OMPI), consoante esmiuçado por Ana Paula Cotrim de Siqueira, a conclusão do citado tratado (em 1996, em Genebra) confirmou a tendência de proteção do software em três categorias:

43 Direito Autoral, op. cit., p. 61.

44 Cf. ALBUQUERQUE, Roberto Chacon de, A Propriedade, op. cit., p. 63. 
“a) Programa de computador: é o conjunto de instruções capaz, quando incorporado a um veículo legível pela máquina, de fazer com que uma máquina disponha de capacidade para processar informações, indique, desempenhe ou execute uma particular função, tarefa ou resultado.

b) Descrição de programa: trata-se da apresentação completa de um processo, expressa por palavras, esquema ou de outro modo, suficientemente pormenorizada para determinar o conjunto de instruções que constitui o programa do computador correspondente.

c) Material de apoio: assim considerado como qualquer material, preparado para ajudar a compreensão ou a aplicação de um programa de computador, por exemplo, as descrições de programas e as instruções para usuários." 45

É importante ressaltar que antes mesmo da celebração dos dois tratados no âmbito da OMPI, ao longo da Rodada Uruguai ${ }^{46}$ do Acordo Geral de Tarifas e Comércio (em inglês, General Agreement on Tariffs and Trade - GATT ${ }^{47}$ ) já havia sido criado um grupo de trabalho vocacionado a conferir ao software o tratamento dado às obras intelectuais.

Ao final do ano de 1993, o objetivo almejado foi atingido mediante a celebração do Tratado sobre Aspectos dos Direitos de Propriedade Intelectual Relacionados ao Comércio (mais conhecido por sua sigla em inglês: TRIPS ${ }^{48}$ - Trade-Related Aspects of Intellectual Property Rights).

Entretanto, Carlos Fernando Mathias de Souza ${ }^{49}$, que representou o Brasil em diversas reuniões da OMPI, destaca que a despeito da necessidade de se promover uma prestação eficaz e adequada dos direitos de propriedade intelectual, o TRIPS objetiva a redução de distorções e obstáculos ao comércio internacional, bem como assegurar que as

45 O direito autoral dos programas de computador, Dissertação de Mestrado apresentada à Faculdade de Direito da Pontifícia Universidade Católica de São Paulo, 2008, p. 39.

46 De acordo com José Carlos da Costa Netto, "rodadas de Negociações Comerciais Multilaterais do GATT (General Agreement on Tariffs and Trade), sendo a última a que inclui normas para a propriedade intelectual no Anexo 1-C, realizada no Uruguai, em 1993, e, consubstanciada na Ata Final que incorpora os seus resultados, firmada em Marraqueche, em 15/4/1994 (essa ata final foi promulgada pelo Decreto 1.355, de 30/12/1994 editado após a sua aprovação pelo Decreto Legislativo 30, de 15/12/1994 e Conferência Diplomática da OMPI - Organização Mundial da Propriedade Intelectual), realizada em Genebra em 20/12/1996" (Direito Autoral, op. cit., p. 60).

47 Roberto Chacon de Albuquerque elucida que o "acordo assinado em Genebra em 1947 (entrou em vigor em 1.01.48) visava a harmonizar as políticas alfandegárias nos mais variados países. Ele fomentou negociações tarifárias multilaterais, para reduzir ou eliminar as restrições e barreiras ao livre comércio. $\mathrm{O}$ GATT nasceu com caráter provisório, em antecipação a uma organização internacional de maior alcance, a OMC. Contudo, em que pese o esforço de institucionalização das relações econômicas transfronteiriças com a criação de organismos internacionais, esta Organização não substituiu o GATT" (A Propriedade, op. cit., p. 59/60).

48 Para Roberto Chacon de Albuquerque "o Acordo TRIPS vincula os Estados membros da OMC, que estão obrigados a implementar, em seus ordenamentos jurídicos, ao menos suas disposições mais relevantes, que são indicadas como um mínimo obrigatório" (A Propriedade, op. cit., p. 67).

49 O Comércio Internacional e os Direitos Conexos: o TRIPS, in Pimenta, Eduardo Salles (coord.), Direitos Autorais - Estudos em homenagem a Otávio Afonso dos Santos, São Paulo: RT, 2007, p. 35. 
medidas e procedimentos destinados a respeitá-los não se tornem obstáculos ao comércio legítimo e que não por acaso tal acordo foi celebrado, sob a égide da Organização Mundial do Comércio (OMC).

A Diretiva ${ }^{50}$ Europeia $^{\text {o }} 250$, de 14 de maio de 1991, também regula a proteção jurídica dos programas de computador e prevê um conceito amplo para software, estabelecendo que este é constituído dos materiais preparatórios da sua concepção e que qualquer forma de expressão de programas (inclusive os que estão incorporados ao hardware) deve ser protegida pelo direito autoral. ${ }^{51}$

A Comunidade Europeia adotou este posicionamento a fim de unificar o tratamento dispensado à matéria pelos Estados membros e para manter o mercado comum em funcionamento sem os efeitos negativos que a diversidade de tratamento poderia causar.

O Tratado sobre Direito de Autor da Organização Mundial de Propriedade Intelectual não traz uma definição de software, mas os integrantes responsáveis pela sua elaboração reconheceram que a melhor definição seria a que foi adotada pelas Disposições Modelo da OMPI sobre a Proteção de Programas de Computador ${ }^{52}$, cujo art. $1^{\text {o }}$, “i”, estabelece: computer program' means a set of instructions capable, when incorporated in a machine-readable medium, of causing a machine having information-processing capabilities to indicate, perform or achieve a particular function, task or result, que - por tradução livre - significa que o programa de computador é uma série de instruções capaz de, quando incorporada num meio legível por uma máquina, levar a máquina apta a processar informações a indicar, desempenhar ou realizar uma função, tarefa ou resultado particular.

50 Gisele Ferreira de Araújo aponta que quando a matéria objeto de tratamento pode causar distorções na formação do mercado interno, é obtida harmonização entre os Estados membros da União Europeia mediante a aprovação de um instrumento legislativo comunitário denominado de diretiva, que estabelece princípios e critérios fundamentais que devem ser adotados pelos Estados membros, a fim de permitir que seja assegurado o bom funcionamento do mercado interno formado pela comunidade interna, pelas instituições e pelos territórios nacionais da União, respeitando-se o princípio da subsidiariedade (Direitos, op. cit. p. 129).

51 Cf. BRANCHER, Paulo Marcos Rodrigues, Contratos, op. cit., p. 20.

52 Elaborada em 1978, por um grupo de técnicos da OMPI. O trabalho foi publicado em inglês, francês, russo e espanhol, com vistas a auxiliar os países na regulamentação da proteção jurídica do software. 
As referidas Disposições Modelo da OMPI também designam como software não apenas o programa ou o grupo de programas que instruem o computador sobre como executar uma tarefa, mas o conjunto formado pelo programa e pelo material de apoio que acompanha sua comercialização, ou seja, os manuais de instrução. ${ }^{53}$

O Tratado de Direitos Autorais da OMPI estabelece, em seu art. $4^{\circ}$, que o software é protegido como obra literária, nos termos do art. $2^{\circ}$ da Convenção de Berna, independentemente da forma ou modo de expressão. No mesmo sentido, o art. 10.1 do TRIPS $^{54}$ prescreve que o programa de computador, seja o código-fonte ou o código-objeto, deve ser protegido como obra literária, observando-se o disposto na Convenção de Berna. ${ }^{55}$

O acordo TRIPS protege tanto os programas de computador cuja expressão concreta se encontre veiculada numa linguagem evoluída (código-fonte), quanto os programas de computador em linguagem de máquina (código-objeto), pois tanto um quanto o outro são expressos numa linguagem artificial, permeada de "palavras, números ou outros símbolos ou indícios numéricos ou verbais". 56

Com base no exposto acima, sob o ponto de vista da tutela do software pelo direito autoral no âmbito internacional, o programa guarda relação não só com o código que é usado para controlar as operações de um computador, mas também com os materiais que refletem os passos intelectuais na preparação deste código, tais como fluxogramas e outros materiais que o acompanham, como descrições e explicações em linguagem comum, que não servem para controlar a máquina, mas que são dirigidos à mente humana, de modo a esclarecer as aplicações do programa. ${ }^{57}$

53 Cf. AlBUQUERQUE, Roberto Chacon de, A Propriedade, op. cit., p. 35.

54 "Art. 10 - Programas de Computador e Compilações de Dados

1. Programas de computador, em código-fonte ou objeto, serão protegidos como obras literárias pela Convenção de Berna (1971).

2. As compilações de dados ou de outro material, legíveis por máquina ou em outra forma, que em função da seleção ou da disposição de seu conteúdo constituam criações intelectuais, deverão ser protegidas como tal. Essa proteção, que não se estenderá aos dados ou ao material em si, se dará sem prejuízo de qualquer direito autoral subsistente nesses dados material."

56 Cf. ALBUQUERQUE, Roberto Chacon de, A Propriedade, op. cit., p. 119.

57 Cf. PAESANI, Liliana Minardi, Direito, op. cit., p. 56/57. 
Portanto, tecnicamente, software, em sentido estrito, coincide com o programa; em sentido amplo, compreende, além do programa, o suporte magnético, o manual de instruções e a documentação acessória. ${ }^{58}$

Independentemente disso, para os fins do presente trabalho o termo software será utilizado como sinônimo, tão somente, de programa de computador (e do seu suporte material quando for o caso).

\subsection{O software no sistema jurídico brasileiro}

Uma vez analisada, em linhas gerais, como se dá a proteção jurídica dos programas de computador no âmbito internacional, resta analisar como a questão é tratada pelo ordenamento jurídico brasileiro.

A Constituição Federal de 1988 assegura textualmente, em seu artigo $5^{\circ}$, XXVII ${ }^{59}$, entre os direitos e garantias fundamentais, que aos autores pertence o direito exclusivo de utilização, publicação ou reprodução de suas obras ${ }^{60}$, transmissível aos herdeiros pelo tempo que a lei fixar. ${ }^{61}$

Eliane Y. Abrão esclarece que os termos "utilização", "publicação" ou "reprodução" poderiam ser substituídos simplesmente por "utilização pública por qualquer meio ou processo". Observa, ainda, que o legislador preferiu o termo genérico "obras" para definir o objeto da proteção autoral, ao invés da expressão "obras literárias, artísticas ou científicas", opção que, segundo ela, se deve à tendência internacional de reconhecer como obras intelectuais também protegidas os programas de computador e a base de dados. Desse modo, conclui a doutrinadora, que "a substituição da 'expressão literárias, artísticas

58 Cf. PAESANI, Liliana Minardi, Direito, op. cit., p. 24.

59 "XXVII - aos autores pertence o direito exclusivo de utilização, publicação ou reprodução de suas obras, transmissível aos herdeiros pelo tempo que a lei fixar;"

60 José de Oliveira Ascensão reconhece que a legislação brasileira tutela o software como se obra literária fosse e de acordo com o direito autoral, mas se opõe a isso por entender que o programa escapa à noção de obra. Para ele, o programa é um processo ou um esquema para a ação e os processos não são tutelados pelo direito de autor, que tutela uma forma. Para ele, o recurso à tutela como direito de autor foi propugnado com base na consideração da fórmula do programa como um texto literário, porém, por acreditar que o software é uma expressão de uma idéia fundamental, ou algoritmo, o programa não pode ser tutelado pelo Direito de Autor. (Direito, op. cit., p. 665/666).

${ }^{61}$ Cf. JUNIOR, Hugo Orrico, Pirataria de Software, São Paulo: MM Livros, 2004, p. 130. 
ou científicas' por 'obras' significa que obras estáticas representam, atualmente, apenas uma das categorias de obras intelectuais protegidas." 62

A Constituição Federal de 1988 confere à União a competência para legislar sobre informática (art. 22, IV ${ }^{63}$ ) e ao Estado confere a missão de promover a expansão tecnológica (art. $218^{64}$ ) e prescreve que o mercado de informática constitui patrimônio nacional, devendo ser incentivado para, dentre outros objetivos, viabilizar o desenvolvimento e a autonomia tecnológica do país $\left(\operatorname{art} .219^{65}\right){ }^{66}$

Por meio do Decreto Legislativo $n^{\circ} 78 / 74$, o Congresso Nacional referendou os textos da Convenção que instituiu a OMPI e da Convenção de Paris para a Proteção da Propriedade Industrial, as quais foram promulgadas pelo Decreto $\mathrm{n}^{\mathrm{o}} 75.541 / 75$.

A Convenção de Berna para a Proteção das Obras Literárias e Artísticas foi referendada no Brasil pelo Decreto Legislativo $n^{\circ} 94 / 74$ e promulgada pelo Decreto $\mathrm{n}^{\circ}$ $75.699 / 75$.

Como decorrência direta dos resultados da Rodada do Uruguai de Negociações Comerciais Multilaterais do GATT, a sua ata final foi referendada pelo Decreto Legislativo

62 Apud SANTOS, Manuella Silva dos, Direitos autoral na era digital: Impactos, controvérsias e possíveis soluções, Dissertação de Mestrado apresentada à Faculdade de Direito da Pontifícia Universidade Católica de São Paulo, 2008, p. 56.

63 “Art. 22. Compete privativamente à União legislar sobre:

(...)

IV - águas, energia, informática, telecomunicações e radiodifusão;

(...)"

64 “Art. 218. O Estado promoverá e incentivará o desenvolvimento científico, a pesquisa e a capacitação tecnológicas.

$\S 1^{\circ}$ - A pesquisa científica básica receberá tratamento prioritário do Estado, tendo em vista o bem público e o progresso das ciências.

$\S 2^{\circ}$ - A pesquisa tecnológica voltar-se-á preponderantemente para a solução dos problemas brasileiros e para o desenvolvimento do sistema produtivo nacional e regional.

$\S 3^{\circ}$ - O Estado apoiará a formação de recursos humanos nas áreas de ciência, pesquisa e tecnologia, e concederá aos que delas se ocupem meios e condições especiais de trabalho.

$\S 4^{\circ}$ - A lei apoiará e estimulará as empresas que invistam em pesquisa, criação de tecnologia adequada ao País, formação e aperfeiçoamento de seus recursos humanos e que pratiquem sistemas de remuneração que assegurem ao empregado, desvinculada do salário, participação nos ganhos econômicos resultantes da produtividade de seu trabalho.

$\S 5^{\circ}$ - É facultado aos Estados e ao Distrito Federal vincular parcela de sua receita orçamentária a entidades públicas de fomento ao ensino e à pesquisa científica e tecnológica."

65 “Art. 219. O mercado interno integra o patrimônio nacional e será incentivado de modo a viabilizar o desenvolvimento cultural e sócio-econômico, o bem-estar da população e a autonomia tecnológica do País, nos termos de lei federal."

66 Cf. BITTAR, Carlos Alberto (coord.), Contratos de Comercialização de "Software", in Novos Contratos Empresariais, São Paulo: RT, 1990, p. 29/30. 
$n^{\circ} 30 / 94$ e promulgada pelo Decreto $n^{\circ} 1.355 / 94$, incorporando à legislação brasileira o acordo sobre direitos de propriedade intelectual relacionados ao comércio. ${ }^{67}$

Sendo assim, é possível aferir que o Brasil aderiu ao regramento internacional que é conferido aos programas de computador, o que explica a edição da Lei $\mathrm{n}^{\circ}$ 9.609/98 (sucessora da Lei $n^{o}$ 7.646/87) que seguiu o regramento internacional já abordado no tocante à proteção da propriedade intelectual de programa de computador e da sua exploração.

$\mathrm{O}$ art. $1^{068}$, da lei do software o define como sendo a expressão de um conjunto organizado de instruções em linguagem natural ou codificada, contida em suporte físico de qualquer natureza, de emprego necessário em máquinas automáticas de tratamento de informação, dispositivos, instrumentos ou equipamentos periféricos, baseados em técnica digital ou análoga, para fazê-los funcionar de modo e para fins determinados.

Além da definição legal de programa de computador, a Lei no 9.609/98, no seu art. $2^{\text {o69}}$, determina que o regime de proteção à propriedade intelectual do software é o conferido às obras literárias pela legislação de direitos autorais e conexos vigentes no Brasil.

67 Cf. SIQUEIRA, Ana Paula Cotrim, O Direito, op. cit., p. 38.

68 "Art. $1^{\circ}$ Programa de computador é a expressão de um conjunto organizado de instruções em linguagem natural ou codificada, contida em suporte físico de qualquer natureza, de emprego necessário em máquinas automáticas de tratamento da informação, dispositivos, instrumentos ou equipamentos periféricos, baseados em técnica digital ou análoga, para fazê-los funcionar de modo e para fins determinados."

69 “Art. $2^{\circ} \mathrm{O}$ regime de proteção à propriedade intelectual de programa de computador é o conferido às obras literárias pela legislação de direitos autorais e conexos vigentes no País, observado o disposto nesta Lei.

$\S 1^{\circ}$ Não se aplicam ao programa de computador as disposições relativas aos direitos morais, ressalvado, a qualquer tempo, o direito do autor de reivindicar a paternidade do programa de computador e o direito do autor de opor-se a alterações não-autorizadas, quando estas impliquem deformação, mutilação ou outra modificação do programa de computador, que prejudiquem a sua honra ou a sua reputação.

$\S 2^{\circ}$ Fica assegurada a tutela dos direitos relativos a programa de computador pelo prazo de cinqüenta anos, contados a partir de $1^{\circ}$ de janeiro do ano subseqüente ao da sua publicação ou, na ausência desta, da sua criação.

$\S 3^{\circ}$ A proteção aos direitos de que trata esta Lei independe de registro.

$\S 4^{\circ}$ Os direitos atribuídos por esta Lei ficam assegurados aos estrangeiros domiciliados no exterior, desde que o país de origem do programa conceda, aos brasileiros e estrangeiros domiciliados no Brasil, direitos equivalentes.

$\S 5^{\circ}$ Inclui-se dentre os direitos assegurados por esta Lei e pela legislação de direitos autorais e conexos vigentes no País aquele direito exclusivo de autorizar ou proibir o aluguel comercial, não sendo esse direito exaurível pela venda, licença ou outra forma de transferência da cópia do programa.

$\S 6^{\circ} \mathrm{O}$ disposto no parágrafo anterior não se aplica aos casos em que o programa em si não seja objeto essencial do aluguel." 
O software é, pois, o componente imaterial do sistema informático e como em qualquer obra intelectual, é possível distinguir nos programas de computador os elementos que dizem respeito ao conteúdo imaterial (composição ideativa) do seu suporte material. ${ }^{70}$

E por assim dizer, o suporte físico, bem material, que o contempla não possui o condão de afastá-lo da tutela do direito autoral, pois trata-se apenas de um elemento que torna o programa apresentável e, muitas vezes, passível de ser disponibilizado a terceiro.

É certo que os bens materiais são tutelados com vistas a coibir a sua subtração ou a sua utilização inadequada, enquanto os bens imateriais são tutelados por regras específicas de direito de propriedade intelectual. Aliás, a diferenciação de ambos vai além, pois os bens corpóreos são passíveis de alienação por meio de compra e venda, mediante tradição, enquanto os bens imateriais são alienados ou cedidos por meio de cessão de direitos. ${ }^{71}$

Consoante já mencionado, tal qual já ocorre no âmbito internacional, a Lei no 9.609/98 equiparou o programa de computador às obras literárias (tuteladas pelo direito autoral), por considerá-lo bem imaterial de cunho criativo e fruto da criação do espírito do autor.

A Lei de Direitos Autorais n 9.610/98 aplicável, portanto, à proteção jurídica do software expressamente prevê que os programas de computador são obras intelectuais como, por exemplo, as obras literárias:

\footnotetext{
“Art. $7^{\circ}$ São obras intelectuais protegidas as criações do espírito, expressas por qualquer meio ou fixadas em qualquer suporte, tangível ou intangível, conhecido ou que se invente no futuro, tais como:

I - os textos de obras literárias, artísticas ou científicas;

(...)

XII - os programas de computador;

(...)

$\S 1^{\circ}$ Os programas de computador são objeto de legislação específica, observadas as disposições desta Lei que lhes sejam aplicáveis.

$\S 2^{\circ}$ A proteção concedida no inciso XIII não abarca os dados ou materiais em si mesmos e se entende sem prejuízo de quaisquer direitos autorais que subsistam a respeito dos dados ou materiais contidos nas obras.

$3^{\circ}$ No domínio das ciências, a proteção recairá sobre a forma literária ou artística, não abrangendo o seu conteúdo científico ou técnico, sem prejuízo dos direitos que protegem os demais campos da propriedade imaterial."
}

70 Cf. AlBUQUERQUE, Roberto Chacon de, A Propriedade, op. cit., p. 46.

71 Cf. WACHOWICZ, Marcos, Revolução, op. cit., p. 235. 
Cumpre ressaltar que os direitos de autor tutelados pela Lei $\mathrm{n}^{\text {o }}$ 9.610/98 contemplam tanto os de ordem patrimonial (direitos reais) quanto os de ordem moral (direitos da personalidade). Para Carlos Alberto Bittar:

\begin{abstract}
"Com efeito, cada bloco de direito cumpre funções próprias: os direitos de cunho moral se relacionam à defesa da personalidade do criador, consistindo em verdadeiros óbices a qualquer ação de terceiros com respeito à sua criação; já os direitos de ordem patrimonial se referem à utilização econômica, representando os meios pelos quais o autor dela pode retirar proventos pecuniários.

Os direitos morais são reconhecidos em função do esforço e do resultado criativo, a saber, da operação psicológica, com a qual se materializa, a partir do nascimento da obra, verdadeira externação da personalidade do autor. Os direitos patrimoniais advém, como resultado da utilização econômica da obra, da decisão do autor de comunicá-lo ao público e sob os modos que melhor atendam ao seu interesse., ${ }^{, 2}$
\end{abstract}

Entretanto, a Lei $\mathrm{n}^{\circ}$ 9.609/98 excetuou os direitos morais do autor do software da órbita do direito autoral. $\mathrm{O}$ seu art. $2^{\circ}$ resguardou apenas o direito do autor reivindicar a paternidade do programa e o direito de opor-se às alterações não autorizadas, quando implicarem deformação, mutilação ou outra modificação do programa, que prejudiquem a sua honra ou a sua reputação.

Diante disso, apenas os direitos patrimoniais do autor do software são resguardados, de modo que a eles nos ateremos quando for abordada a outorga de licença para o uso do programa.

Pois bem. O programa de computador possui duas características distintas, uma de ordem mecânica e outra de ordem simbólica, ou seja, qualquer programa é uma obra literária que especifica mecanicamente a série de procedimentos que o computador precisa seguir para executar a tarefa desejada pelo programador, bem como representa o espírito criativo e intelectual do seu criador. ${ }^{73}$

Para Renato Lacerda de Lima Gonçalves ${ }^{74}$, a linguagem empregada para escrever um programa é relativamente próxima à natural, de maneira que o seu desenvolvimento e a sua programação assemelha-se à atividade do jurista que elabora um parecer.

72 Direito de Autor, São Paulo: Forense Universitária, 2004, p. 46.

73 Cf. ALBUQUERQUE, Roberto Chacon de, A Propriedade, op. cit., p. 45.

74 GONÇALVES, Renato Lacerda de Lima, A Tributação, op. cit., p. 52. 
A Lei $n^{0}$ 9.609/98 também prevê que a proteção dos direitos da propriedade intelectual do software será de 50 anos e que independe de registro ${ }^{75}$. O registro é facultativo e fica a critério do titular, já que não se trata de ato constitutivo do direito de autor.

A causa constitutiva do direito autoral é sempre a criação da obra. O registro é uma presunção juris tantum e, portanto, possui o condão de asseverar, até que seja provado o contrário, que o autor do software é aquele que primeiro procedeu ao seu registro. Assim, salvo prova em contrário, é autor aquele em cujo nome foi registrada a obra intelectual. ${ }^{76}$

Hugo Orrico Junior ${ }^{77}$ aduz que, sendo o registro mera faculdade do titular, o autor tanto pode optar por não fazer o registro quanto por fazer esse registro quando e onde prefira, até mesmo, por exemplo, em um Cartório de Registro de Títulos e Documentos, caso em que apenas não estaria protegido pelo sigilo dos dados informados, não havendo como impedir que outros deles tomassem conhecimento livremente.

A exceção é feita por conta dos contratos que contemplam a transferência de tecnologia, que para produzirem efeitos em relação a terceiros deverão, obrigatoriamente, ser registrados perante o Instituto Nacional da Propriedade Industrial - INPI (art. 11, parágrafo único da Lei $\left.n^{\circ} 9.609 / 98^{78}\right){ }^{79}$

O mesmo pode ser dito em relação às obras intelectuais estrangeiras e, portanto, aos programas estrangeiros. Nos termos do art. $2^{\circ}, \S 4^{\circ}$, da Lei $n^{\circ} 9.609 / 98$, a proteção da

75 O registro do programa de computador perante o Instituto Nacional da Propriedade Industrial - INPI é facultativo e de acordo com os interesses do seu titular, nos termos do art. $2^{\circ}, \S 3^{\circ}$ e art. $3^{\circ}$ da Lei $n^{\circ}$ 9.609/98 e do art. $1^{\circ}$, do Decreto $n^{\circ} 2.556 / 98$. Contudo, em se tratando de transferência de tecnologia do programa de computador o respectivo contrato deverá ser registrado no INPI para que produza efeitos perante terceiros (art. 11, da Lei $n^{\circ}$ 9.609/98), além de ser obrigatória a entrega, por parte do fornecedor ao receptor de tecnologia, da documentação completa, em especial do código-fonte comentado, memorial descritivo, especificações funcionais internas, diagramas, fluxogramas e outros dados técnicos necessários à absorção da tecnologia.

76 Cf. ALBUQUERQUE, Roberto Chacon de, A Propriedade, op. cit., p. 112.

77 Pirataria, op. cit., p. 134.

78 “Art. 11. Nos casos de transferência de tecnologia de programa de computador, o Instituto Nacional da Propriedade Industrial fará o registro dos respectivos contratos, para que produzam efeitos em relação a terceiros.

Parágrafo único. Para o registro de que trata este artigo, é obrigatória a entrega, por parte do fornecedor ao receptor de tecnologia, da documentação completa, em especial do código-fonte comentado, memorial descritivo, especificações funcionais internas, diagramas, fluxogramas e outros dados técnicos necessários à absorção da tecnologia."

79 Cf. JUNIOR, Hugo Orrico, Pirataria, op. cit., p. 134. 
propriedade intelectual do software é assegurada aos estrangeiros domiciliados no exterior, desde que o país de origem do programa conceda, aos brasileiros e estrangeiros domiciliados no Brasil, direitos equivalentes. Em outras palavras, a Lei $n^{\circ}$ 9.609/98 adota o princípio da reciprocidade para fins de tutela dos direitos autorais sobre software de origem estrangeira.

A referida lei elegeu o critério do País de origem do programa e não o critério da nacionalidade ou do domicílio do estrangeiro e a lei brasileira não define o que seja país de origem do programa, mas esse conceito está descrito na Convenção de Berna, em seu artigo 3(b), e na Convenção Universal ${ }^{80}$, no artigo II, como sendo o lugar da primeira publicação da obra. ${ }^{81}$

O art. 11, da Lei de Direitos Autorais, prevê que é considerado autor ${ }^{82}$ a pessoa física criadora da obra literária, artística ou científica, contudo, o seu art. 22 estabelece que a proteção concedida ao autor poderá ser aplicada às pessoas jurídicas nos casos nela previstos.

A Lei $n^{\circ}$ 9.609/98 não é expressa como a Lei $n^{\circ}$ 9.610/98, mas a partir do seu art. $3^{\circ}, \S 1^{\circ}$, I, pode-se chegar à mesma conclusão, ou seja, a lei tutela os direitos da pessoa física ou jurídica. Confira-se:

80 José de Oliveira Ascensão esclarece que a Convenção Universal foi aprovada em Genebra em 1952 e revista em Paris em 1971, conjuntamente com a Convenção de Berna. É administrada pela UNESCO e é sensivelmente menos exigente que a Convenção de Berna (Direito, op. cit., p. 641). José Carlos Costa Netto informa que: "a Convenção de Berna se diferenciava da Convenção Universal pela distinção existente entre o sistema do direito de autor, originado com a Revolução Francesa e de natureza subjetiva (fundado na proteção da personalidade do autor) e o sistema do 'copyright' ou objetivo (baseado na proteção da obra) originado na Lei da Rainha Ana, em 1710 e na Constituição dos Estados Unidos da América, de 1776. Esse antagonismo entre os dois sistemas foi se evidenciando com o desenvolvimento internacional - e revisões - da Convenção de Berna. Tanto que somente realizou-se a Convenção Universal em 1952, ou seja, mais de 60 anos após o início da vigência do diploma de Berna. O texto da Revisão de Paris, de 1971, é o que se encontra vigente, assimilado pelo nosso Direito Positivo Interno pelo Decreto Legislativo 55, de 28/6/1975 e promulgado pelo Decreto no 76.905 , de 24/12/1975 em que, reconhecendo a prevalência do regime de Berna ('direito de autor') sobre o da Convenção Universal (copyright), estabelece que: 'A Convenção Universal sobre o Direito de Autor não será aplicável, nas relações entre os países vinculados pela Convenção de Berna, no que se refere ao à proteção das obras que, nos termos da referida Convenção de Berna, tenham como país de origem um dos países da União de Berna (alínea 'c' da declaração anexa relativa ao art. 17 - que dispõe que a convenção Universal em nada afeta a de Berna - da Convenção Universal)" (Direito, op. cit., p. 59).

81 Cf. SIQUEIRA, Ana Paula Cotrim, O Direito, op. cit., p. 43.

82 José de Oliveira Ascensão sustenta que “autor" é uma palavra ambígua, que pode designar: a) o criador intelectual da obra; b) o titular originário dela; c) o titular atual (Direito, op. cit., p. 69). 
“Art. $3^{\circ}$ Os programas de computador poderão, a critério do titular, ser registrados em órgão ou entidade a ser designado por ato do Poder Executivo, por iniciativa do Ministério responsável pela política de ciência e tecnologia.

$\S 1^{\circ} \mathrm{O}$ pedido de registro estabelecido neste artigo deverá conter, pelo menos, as seguintes informações:

I - os dados referentes ao autor do programa de computador e ao titular, se distinto do autor, sejam pessoas físicas ou jurídicas;

II - a identificação e descrição funcional do programa de computador; e

III - os trechos do programa e outros dados que se considerar suficientes para identificá-lo e caracterizar sua originalidade, ressalvando-se os direitos de terceiros e a responsabilidade do Governo.

$\S 2^{\circ}$ As informações referidas no inciso III do parágrafo anterior são de caráter sigiloso, não podendo ser reveladas, salvo por ordem judicial ou a requerimento do próprio titular."

Plínio Cabral ${ }^{83}$ preceitua que só a pessoa física, ser humano, possui condições para criar uma obra intelectual e que a pessoa jurídica pode ser titular de direitos de autor. Entretanto, para ele, são dois conceitos que, no caso do autor pessoa física, podem estar reunidos na mesma pessoa, o que não acontece quando se trata de pessoa jurídica (uma ficção), já que esta existe para praticar atos necessários à vida industrial e comercial (um ente desprovido de vontade própria e sensibilidade criativa). ${ }^{84}$

Carlos Alberto Bittar ${ }^{85}$ pontua que o criador da obra protegida é titular originário de direitos, ou seja, é a pessoa que concebe e materializa a obra de engenho, qualquer que seja a sua idade, estado ou condições mentais, inclusive, os incapazes de todos os níveis.

O doutrinador também assevera que, por via derivada, outras pessoas podem integrar o sistema autoral, seja na circulação jurídica da obra (por força de contratos próprios firmados pelo titular como, por exemplo, os de cessão, em que podem ser transmitidos um, alguns ou todos os direitos patrimoniais), seja por vínculo sucessório ${ }^{86}$ (neste caso a derivação é plena).

Ressalte-se que a autoria é um direito moral irrenunciável e inalienável do autor, enquanto a titularidade de direitos autorais é aquela que confere poderes a outrem para o

\footnotetext{
83 A Nova, op. cit., p. 36.

84 Carlos Alberto Bittar discorda deste entendimento e sustenta que a criação de obras intelectuais nasce, também, no âmbito de pessoas jurídicas, notadamente as especializadas em idear e produzir obras de engenho, de sorte que tais empresas também podem ser titulares de direitos autorais, tanto por via originária, pela criação, como derivada, pela transferência de direitos (Direito, op. cit., p. 34). Direito, op. cit., p. 33/34.

86 A tal título, vide o art. 41, da Lei n ${ }^{\circ}$ 9.610/98.
} 
exercício do direito patrimonial, ou seja, para a exploração econômica da obra mediante a transmissão dos direitos autorais patrimoniais. ${ }^{87}$

Para as situações em que o programa é desenvolvido em decorrência da relação de emprego, prestação de serviço ou vínculo estatutário, a Lei no 9.609/98 consigna que os direitos autorais (de cunho patrimonial) relativos ao programa pertencerão exclusivamente ao empregador/contratante:

\begin{abstract}
"Art. $4^{\circ}$ Salvo estipulação em contrário, pertencerão exclusivamente ao empregador, contratante de serviços ou órgão público, os direitos relativos ao programa de computador, desenvolvido e elaborado durante a vigência de contrato ou de vínculo estatutário, expressamente destinado à pesquisa e desenvolvimento, ou em que a atividade do empregado, contratado de serviço ou servidor seja prevista, ou ainda, que decorra da própria natureza dos encargos concernentes a esses vínculos. (...)"
\end{abstract}

Aliás, consoante aduz José de Oliveira Ascensão ${ }^{88}$, "na produção de programas a posição das grandes empresas é fundamental, basta pensar que ninguém conhece um programa do Sr. X, mas por ser da Apple ou da Microsoft”.

Feitas estas ponderações, nos termos do art. $2^{\text {o89 }}$, da Lei ${ }^{\circ}$ 9.609/98 e dos arts. $11^{90}$, $22^{91}$ e $28^{92}$ da Lei $n^{\circ} 9.610 / 98$, ao criador do software (e aos titulares dos direitos autorais por derivação) é assegurada a proteção jurídica dos direitos patrimoniais que é dada aos autores ${ }^{93}$ de obras intelectuais.

87 Cf. WILlington, João e OLIVEIRA, Jaury N. de, A nova Lei Brasileira de Direitos Autorais, Rio de Janeiro: Lumen Juris, 2002, p. 19.

88 Direito, op. cit., p. 670.

$89 \mathrm{O}$ citado art. $2^{\mathbf{0}}$, expressamente, excetua a proteção dos direitos morais, resguardando apenas a paternidade do programa e o direito do autor de opor-se a alterações não autorizadas, quando estas impliquem deformação, mutilação ou outra modificação do programa de computador, que prejudiquem a sua honra ou a sua reputação.

90 "Art. 11. Autor é a pessoa física criadora de obra literária, artística ou científica."

91 "Art. 22. Pertencem ao autor os direitos morais e patrimoniais sobre a obra que criou."

92 "Art. 28. Cabe ao autor o direito exclusivo de utilizar, fruir e dispor da obra literária, artística ou científica."

93 Ivana Go Crivelli relembra que a titularidade de direitos autorais (por sucessão) obedece a regra geral do Código Civil e pode originar-se da sucessão legítima ou testamentária. Quando do falecimento do autor, transmite-se a titularidade dos direitos autorais do autor falecido aos herdeiros e/ou legatários. A ordem de sucessão é aplicada peculiarmente pelo direito de autor. O Estado não sucede o autor, a obra cai em domínio público e não se integra ao patrimônio imaterial do Estado (A Regulamentação da Contratação de Direitos Autorais, in Pimenta, Eduardo Salles (coord.), Direitos Autorais - Estudos em homenagem a Otávio Afonso dos Santos, São Paulo: RT, 2007, p. 152). 
No que tange à transferência dos direitos de autor sobre os programas de computador, a Lei no 9.609/98 não é muito detalhista. Sendo assim, é possível aplicar, subsidiariamente, a Lei $\mathrm{n}^{\text {0 }}$ 9.610/98, cujo art. $49^{94}$ e seguintes estabelecem que os direitos de autor poderão ser total ou parcialmente transferidos a terceiros, por ele ou por seus sucessores, a título universal ou singular, pessoalmente ou por meio de representantes com poderes especiais, por meio de licenciamento, concessão, cessão ou por outros meios admitidos em Direito.

Seguindo o que dispõe o art. 9.2 do TRIPS, segundo o qual a proteção pelos direitos autorais deve ser aplicada às expressões e não às ideias, procedimentos, métodos de operação ou conceitos matemáticos, a Lei $n^{\circ} 9.610 / 98$, no seu art. $8^{\circ}$, I ${ }^{95}$, em rol taxativo, elenca o que não é passível de proteção pelos direitos autorais como, por

94 “Art. 49. Os direitos de autor poderão ser total ou parcialmente transferidos a terceiros, por ele ou por seus sucessores, a título universal ou singular, pessoalmente ou por meio de representantes com poderes especiais, por meio de licenciamento, concessão, cessão ou por outros meios admitidos em Direito, obedecidas as seguintes limitações:

I - a transmissão total compreende todos os direitos de autor, salvo os de natureza moral e os expressamente excluídos por lei;

II - somente se admitirá transmissão total e definitiva dos direitos mediante estipulação contratual escrita;

III - na hipótese de não haver estipulação contratual escrita, o prazo máximo será de cinco anos;

IV - a cessão será válida unicamente para o país em que se firmou o contrato, salvo estipulação em contrário;

V - a cessão só se operará para modalidades de utilização já existentes à data do contrato;

VI - não havendo especificações quanto à modalidade de utilização, o contrato será interpretado restritivamente, entendendo-se como limitada apenas a uma que seja aquela indispensável ao cumprimento da finalidade do contrato.

Art. 50. A cessão total ou parcial dos direitos de autor, que se fará sempre por escrito, presume-se onerosa.

$\S 1^{\circ}$ Poderá a cessão ser averbada à margem do registro a que se refere o art. 19 desta Lei, ou, não estando a obra registrada, poderá o instrumento ser registrado em Cartório de Títulos e Documentos.

$\S 2^{\circ}$ Constarão do instrumento de cessão como elementos essenciais seu objeto e as condições de exercício do direito quanto a tempo, lugar e preço.

Art. 51. A cessão dos direitos de autor sobre obras futuras abrangerá, no máximo, o período de cinco anos.

Parágrafo único. O prazo será reduzido a cinco anos sempre que indeterminado ou superior, diminuindose, na devida proporção, o preço estipulado.

Art. 52. A omissão do nome do autor, ou de co-autor, na divulgação da obra não presume o anonimato ou a cessão de seus direitos."

95 “Art. $8^{\circ}$ - Não são objeto de proteção como direitos autorais de que trata esta Lei:

I - as idéias, procedimentos normativos, sistemas, métodos, projetos ou conceitos matemáticos como tais;

II - os esquemas, planos ou regras para realizar atos mentais, jogos ou negócios;

III - os formulários em branco para serem preenchidos por qualquer tipo de informação, científica ou não, e suas instruções;

IV - os textos de tratados ou convenções, leis, decretos, regulamentos, decisões judiciais e demais atos oficiais;

$\mathrm{V}$ - as informações de uso comum tais como calendários, agendas, cadastros ou legendas;

VI - os nomes e títulos isolados;

VII - o aproveitamento industrial ou comercial das idéias contidas nas obras.” 
exemplo, as ideias, os procedimentos normativos, os sistemas, os métodos, os projetos ou conceitos matemáticos. ${ }^{96}$

Para Plínio Cabral, ${ }^{97}$ o fato de as ideias não serem objeto de proteção constitui conceito universalmente aceito, já que a lei protege a manifestação concreta do pensamento criador, aquele que se concretiza numa base que pode ser vista, ouvida, sentida e, sobretudo, apropriada como bem móvel.

Segundo Andreas Raubenheimer e Andre Bertrand ${ }^{98}$, essa ausência de proteção das ideias se deve ao fato de que os algoritmos em si e outros ensinamentos ou regras matemáticas ou técnicas fazem parte da doutrina científica, a qual deve estar disponível a todos.

Para Roberto Chacon de Albuquerque ${ }^{99}$, o direito autoral protege não apenas o software enquanto sequência de instruções (esteja em linguagem evoluída/código-fonte ou em linguagem de máquina/código-objeto) que instrui o computador sobre como ele deve executar uma tarefa, como também o trabalho de concepção preparatório (trabalhos de natureza linguística como os algoritmos e os de natureza gráfica como os fluxogramas), resultado das diferentes etapas preliminares de desenvolvimento, desde que se revistam de forma concreta e original, assim como o material que o acompanha, como os manuais do usuário.

Outro ponto de extrema importância para o presente estudo que não pode deixar de ser mencionado é que, no Brasil, o uso de programa de computador deve ser objeto de contrato de licença. É o que dispõe o art. $9^{\circ}$ da referida lei:

\footnotetext{
“Art. $9^{\circ} \mathrm{O}$ uso de programa de computador no País será objeto de contrato de licença.

Parágrafo único. Na hipótese de eventual inexistência do contrato referido no caput deste artigo, o documento fiscal relativo à aquisição ou licenciamento de cópia servirá para comprovação da regularidade do seu uso."
}

96 Cf. BRANCHER, Paulo Marcos Rodrigues, Contratos, op. cit., p. 21.

97 A Nova, op. cit., p. 33.

98 Apud BRANCHER, Paulo Marcos Rodrigues, Contratos, op. cit., p. 21.

99 A Propriedade, op. cit., p. 134. 
Ressalte-se que o uso e a exploração comercial dos direitos sobre programas de computador são regidos pela Lei $\mathrm{n}^{\circ}$ 9.609/98, de modo que a Lei ${ }^{\circ}$ 9.610/98 é aplicada subsidiariamente à citada lei especial.

\subsection{Breves considerações sobre a exploração econômica do software enquanto obra protegida pelo direito autoral}

Consoante ensina Carlos Alberto Bittar ${ }^{100}$, a interpretação dos contratos em matéria de criação e de uso de software envolve um complexo esquema protetivo, estatal e privado, que deve ser respeitado. Segundo ele:

\footnotetext{
"Ainda sobre interpretação, deve-se anotar que não importa o nomen iuris do contrato, mas sim o conteúdo, buscando-se a intenção das partes no equacionamento de questões que surjam, respeitadas sempre as normas de ordem pública da lei. Assim, é que, na prática, sob o nome 'contrato de prestação de serviços', se tem o de 'encomenda'; muitas vezes se fala em 'licença', mas no fundo se trata de cessão e assim por diante."101
}

Para o doutrinador, há que se atentar para os valores da sociedade - muitos explicitamente amparados por normas de ordem pública inscritas na legislação do setor, na legislação do comércio exterior e na transferência de recursos para o estrangeiro - mas também para os direitos dos criadores protegidos pela lei do software.

E, por assim dizer, ele assevera que somente os direitos enunciados expressamente no contrato poderão ser usufruídos, o que decorre da interpretação restritiva aplicável aos negócios envolvendo direitos autorais (art. $4^{\circ}$, da Lei $n^{\circ}$ 9.610/98).

Pontua, ainda, que é necessário observar os demais princípios que inspiram a legislação autoral, mas sempre respeitando a primazia da lei do software em razão do princípio da especificidade da norma.

Segundo Bittar, os contratos do setor devem adequar-se a todo o extenso elenco, formal e substancial, de normas que regem a matéria, para que as negociações resultem na fruição do direito pactuado e destinado ao interessado, bem como na percepção da

${ }_{101}$ BITTAR, Carlos Alberto (coord.), Contratos, op. cit., p. 33.

101 Direito, op. cit., p. 93. 
remuneração pelo titular e o recebimento pelo Estado, quando for o caso, dos valores que a título de tributo e de emolumentos lhe couberem. ${ }^{102}$

A Lei $\mathrm{n}^{\text {o }} 9.609 / 98$ prevê que o software pode ser comercializado por meio de contrato próprio, por meio de licença, encomenda, ou cessão (art. $9^{\circ}$ a 11 ), ficando os de origem estrangeira sujeitos a regras próprias quanto à titularidade, à circulação e à transferência de tecnologia (art. $2^{\circ}, \S 2^{\circ}$, e arts. 10 e 11); atribui à empresa os direitos relacionados quando o criador é assalariado (art. $4^{\circ}$ ); impõe algumas limitações (art. $6^{\circ}$ ) e em face da natureza dessa criação, permite seja feita cópia de segurança para uso do interessado. $^{103}$

$\mathrm{O}$ art. $4^{\mathrm{o}}$, da Lei $\mathrm{n}^{\mathrm{o}}$ 9.609/98 prevê que o desenvolvimento de programa de computador pode ocorrer por meio de 3 formas de contratação, quais sejam, (i) relação de emprego (contrato de trabalho); (ii) vínculo estatutário; e, (iii) prestação de serviço. E, salvo determinação em contrário, a lei determina que os direitos autorais sobre o software desenvolvido pertencerão exclusivamente ao empregador, ao órgão público ou ao contratante do serviço. ${ }^{104}$

Não se pode esquecer que a autoria é um direito moral irrenunciável e inalienável do autor, de modo que é a titularidade de direitos autorais que confere poderes a outrem para o exercício do direito patrimonial, ou seja, para a exploração econômica da obra mediante a transmissão dos direitos autorais patrimoniais. ${ }^{105}$

De acordo com o art. $9^{\circ}$, da Lei $n^{\circ} 9.609 / 98$, o uso do programa deve se dar por meio de contrato de licença de uso, que consiste na outorga de uma autorização de uso por parte do titular dos direitos autorais sobre o programa em favor do usuário interessado. A licença de uso determina as condições de utilização do programa, o prazo, as limitações quanto à obtenção de cópias, etc.

102 BITTAR, Carlos Alberto (coord.), Contratos, op. cit., p. 35.

103 Cf. BITTAR, Carlos Alberto, Direito, op. cit., p. 85.

${ }^{104}$ Nos termos do $\$ 2^{\circ}$, do art. $4^{\circ}$, da Lei $\mathrm{n}^{\circ} 9.609 / 98$, pertencerão, com exclusividade, ao empregado, contratado de serviço ou servidor os direitos concernentes a programa de computador gerado sem relação com o contrato de trabalho, prestação de serviços ou vínculo estatutário, e sem a utilização de recursos, informações tecnológicas, segredos industriais e de negócios, materiais, instalações ou equipamentos do empregador, da empresa ou entidade com a qual o empregador mantenha contrato de prestação de serviços ou assemelhados, do contratante de serviços ou órgão público.

105 Cf. WILlingtON, João e OLIVEIRA, Jaury N. de, A nova, op. cit., p. 19. 
Em não havendo contrato formal que disponha sobre o uso do programa, nos termos do parágrafo único do art. $9^{\circ}$, da Lei $\mathrm{n}^{\circ}$ 9.609/98, a nota fiscal de aquisição da cópia do software fará as vezes do contrato de licença de uso e será o bastante para comprovar a sua regularidade.

Além do contrato de desenvolvimento e da licença de uso, o software pode ser objeto de outros contratos como, por exemplo, o de "comercialização". Contudo, acreditamos que a terminologia mais adequada não seja essa em razão do objeto em estudo constituir obra intelectual, imaterial/incorpórea/intangível ${ }^{106}$, de caráter utilitário que não é passível de ser posta no comércio, a despeito de poder ser explorada economicamente e ser objeto de transação entre partes por meio da cessão ou concessão de direitos.

Aliás, o art. 9, da Lei n 9.609/98, ao tratar da "comercialização" do software faz uso da expressão contrato de licença de direitos de comercialização, o que - a nosso ver é indicativo de que o objeto em questão é explorado economicamente por meio da cessão/concessão de direitos e não da "compra e venda".

Para fins de comercialização, a licença consolida-se no poder outorgado pelo titular a terceiros, no sentido de que estes possam autorizar o uso do programa de computador, mediante remuneração, configurando assim uma segunda licença. ${ }^{107}$

Segundo Manoel J. Pereira dos Santos ${ }^{108}$, a finalidade do contrato de "comercialização" é outorgar ao licenciado o direito de conceder licenças de uso do programa. Por meio desta licença o licenciado adquire o direito de reproduzir o programa, sublicenciá-lo a terceiros para "comercialização" e conceder licenças de uso.

Além do contrato de desenvolvimento, de uso e de "comercialização" outros tantos ${ }^{109}$ podem ser pactuados entre as partes com vistas a transferir ou explorar os direitos patrimoniais do autor do software, mas não nos ateremos a cada um deles por não guardarem relação com o objeto em estudo.

\footnotetext{
106 A "posse" de bens intangíveis não é buscada/recuperada pelo seu titular.

107 Cf. BRANCHER, Paulo Marcos Rodrigues, Contratos, op. cit., p. 52.

${ }^{108}$ Licença de Software, Revista da Associação Brasileira de Propriedade Intelectual n 25, p. 39.

109 A título de exemplo, citem-se: contrato de distribuição, de agência, de mandato, fornecimento, etc.
} 


\subsection{Licença de uso x Cessão de direitos}

Em que pese o objeto do presente trabalho seja analisar os aspectos controvertidos da tributação do uso do software, cuja licença está expressamente prevista no art. $9^{\circ}$, da Lei $\mathrm{n}^{\circ}$ 9.609/98, a fim de bem compreendê-lo, necessário se faz diferenciar a licença de uso da cessão de direitos.

Isso porque, muitos autores utilizam o termo cessão de direitos (lato sensu) para designar licença ou licenciamento, o que pode acabar comprometendo a compreensão destes últimos.

Hugo Orrico Junior ${ }^{110}$, por exemplo, defende que os programas de computador entram no mundo comercial através do seu licenciamento, que - segundo ele - é a forma jurídica prevista na lei para que o detentor de um direito autoral autorize alguém a reproduzir ou utilizar o seu software.

Para ele, o licenciamento ou a cessão de direitos de uso de um programa de computador, em regra, é feito em caráter de exclusividade, é intransferível e o direito de usar o programa não inclui - salvo disposição em contrário - o direito de transferí-lo a outrem.

O citado autoralista defende que o termo "licença" deve ser entendido em seu sentido amplo, de tal forma que são contratos de licença, para efeitos de cessão e regulamentação dos direitos de uso, não apenas os contratos stricto sensu (formalmente redigidos). ${ }^{111}$

É bem verdade que o legislador não se valeu da melhor técnica legislativa ao redigir a Lei no 9.609/98. Ao tratar da "comercialização" dos programas, o art. 10 faz expressa menção ao contrato de licença de direito de comercialização, deixando subentendido que a comercialização também deve ser objeto de licenciamento.

\footnotetext{
${ }^{110}$ Pirataria, op. cit., p. 67.

111 JUNIOR, Hugo Orrico, Pirataria, op. cit., p.81.
} 
Helio Alberto Bellintani Júnior ${ }^{112}$ faz uma adequada crítica ao legislador ao reputálo infeliz na utilização da expressão "contratos de licença" para designar os contratos que tenham como objeto os direitos de comercialização.

É por conta da previsão legal que a licença ou licenciamento são instrumentos para negociar direitos de cunho intelectual, de uso empresarial em si (licença pura) ou em conjugação com outras atividades como, por exemplo, a fabricação de produtos, a distribuição, ou a comercialização de bens e outros. ${ }^{113}$

A suposta equivalência entre a licença e a cessão não é unânime na doutrina. Carlos Alberto Bittar ${ }^{14}$ alerta para as diferenças entre os dois institutos.

De acordo com Bittar, por meio do contrato de licença o titular de direitos concede a outrem apenas o uso do bem, nos fins e pelas condições convencionadas ${ }^{115}$, podendo revestir-se, ou não, de exclusividade:

\begin{abstract}
"O contrato de licença ou licenciamento pode ser celebrado diretamente entre o titular (ou seus representantes) e o interessado, mas também por intermédio de distribuidores, que atuam na colocação aos usuários. Cabe, ainda, na relação entre o criador do programa e a empresa autorizada a comercializá-lo.

Normalmente, com esse contrato o autor recebe remuneração em função da concessão de direitos a vários interessados, nos termos de ajustes celebrados com cada um, mas permanecendo sob sigilo a fórmula do programa.

O alcance deste contrato é limitado: o titular conserva sempre os direitos de caráter moral, além dos de cunho patrimonial não negociados, ou não existentes, à época do ajuste. Ficam, pois, sob seu controle os usos autorizados, podendo o titular, desde que não haja exclusividade, proceder a sucessivos licenciamentos, submetidos à remuneração estipulada nos contratos, obedecidas, no entanto, as regras legais imperativas, incidentes, em especial quanto à internação de produto estrangeiro e transferência de tecnologia em geral.

Mesmo quando negocia todos os direitos patrimoniais disponíveis, conserva o titular o controle de sua criação, podendo exercer fiscalização sobre os usos concedidos e tomar medidas tendentes à proteção de seu interesse, em caso de violação a seus direitos. Além disso, detém mecanismos de defesa do segredo (entenda-se, do código-fonte)." 116
\end{abstract}

112 Contrato de licenciamento de uso dos programas de computador destinados à gestão empresarial, Dissertação de Mestrado apresentada à Faculdade de Direito da Pontifícia Universidade Católica de São Paulo, 2003, p. 83.

113 Cf. BITTAR, Carlos Alberto, Contratos, op. cit., p. 39.

114 Contratos, op. cit., p. 39.

115 Bittar alerta para os requisitos do contrato, conforme segue: "O contrato deve indicar, com precisão, o bem envolvido, descrevendo-o de forma a individualizá-lo, e enunciar: os usos correspondentes e a respectiva extensão, no tempo e no espaço; as finalidades da contratação; a remuneração ao titular e o modo de pagamento; os mecanismos de prestação de contas; a possibilidade, ou não, de sublicenciamento e outras cláusulas próprias" (Contratos, op. cit., p. 41).

116 BITTAR, Carlos Alberto (coord.), Contratos, op. cit., p.40/42. 
Carlos Alberto Bittar também ensina que diferentemente do contrato de licença, o contrato de cessão é aquele pelo qual o titular do direito transfere, total ou parcialmente, a outra pessoa, ou empresa, direitos sobre a sua criação, normalmente, mediante remuneração. A cessão realiza a função de transmissão de direitos ao interessado, possibilitando, sucessivamente, o aproveitamento da obra por vários titulares e, desde que efetivada de modo legítimo, a coexistência de usos diversos, por pessoas e por empresas distintas:

\begin{abstract}
"Tal contrato é próprio de negócios em que o titular pretende trespassar a terceiros seus direitos, inclusive o segredo, permitindo-lhes todos os usos possíveis. Corresponde, pois, à alienação do bem envolvido, sob o prisma patrimonial, de modo que o interessado fica livre para as utilizações que couber, quando total a transmissão. Quando parcial, prevalece a mesma orientação, naturalmente restrita aos direitos e aos termos em que se concluir o negócio.

É ainda a figura com que se perfazem os negócios de venda de máquinas (hardware) com software residente, entendendo-se, nesse caso, que se opera a transferência de direitos aos usuários, eis que o programa é considerado componente essencial do computador. Além disso, sendo de uso geral e, de regra, apenas adptável à máquina correspondente, não tem o respectivo titular preocupação em preservar o segredo do programa." $" 117$
\end{abstract}

José Carlos Costa Netto ${ }^{118}$ entende que "na cessão opera-se a transferência dos direitos patrimoniais de autor, adquirindo, assim, o cessionário a titularidade (derivada) desses direitos".

Eduardo Vieira Manso, por sua vez, reconhece que a cessão é um negócio jurídico típico no Direito Autoral e que é causa de obrigações que podem ser resumidas como "a transferência da titularidade dos direitos que são objeto do respectivo contrato”. Para ele:

“O 'contrato de cessão de direitos autorais' é típico, no direito brasileiro,
representando, a cessão, um autônomo negócio jurídico, gerador de direitos e de
obrigações patrimoniais específicos do Direito Autoral, em que se opera a
substituição subjetiva do titular de tais direitos. Sabe-se que, no sistema geral do
Direito das Obrigações, a cessão não é, em si mesma, um negócio jurídico. Ela
apenas constitui um indicador de certo modo de cumprir determinadas
obrigações. Assim, quem se obriga a vender, quando cumpre essa obrigação,
cede ao comprador o direito de propriedade, quase sempre transmitindo
simultaneamente a posse da coisa vendida. Por isso é que Gondin Netto, em
monografia à qual ele mesmo se refere em parecer publicado na RT $274 / 63$,
disse que 'a cessão não é ato constitutivo da obrigação, mas um ato de
disposição, pelo qual se dá cumprimento a uma obrigação de transferir para
outrem um direito de nosso patrimônio, um crédito, um objeto incorpóreo...'.
Pode-se, portanto, afirmar que a cessão não é um negócio causal, no direito

117 BITTAR, Carlos Alberto (coord.), Contratos, op. cit., p. 43/44.

118 Direito, op. cit., p. 59. 
comum, a priori, que está logicamente situada antes, e que é determinante do ato de ceder." 119

Paulo Marcos Rodriguez Brancher ${ }^{120}$ lembra que por meio de cessão de direitos patrimoniais o direito de exploração econômica do software pode ser totalmente transferido a terceiros, sem que seu titular possa reivindicar futuramente o pagamento de qualquer outro valor além daquele estabelecido contratualmente.

Renato Lacerda de Lima Gonçalves ${ }^{121}$ defende que a cessão total dos direitos autorais a terceiros é equiparada à "compra e venda". Ele sustenta que as hipóteses em que se verifica efetivamente a "comercialização" do software são aquelas em que o titular dos direitos autorais do programa cede ou transfere totalmente esses direitos a outra pessoa, mediante o pagamento de determinado preço ou a título gratuito.

Quanto a este entendimento, fazemos uma ressalva em relação à sua parte final, pois entendemos que a equiparação da cessão de direitos à "compra e venda" somente é possível se houver contraprestação (obrigação onerosa).

Muito embora acreditamos ser impróprio utilizar a expressão "compra e venda" para as questões envolvendo bens intangíveis/imateriais, reconhecemos que a operação que mais se aproxima daquela é - de fato - a cessão onerosa e integral dos direitos autorais patrimoniais sobre o software, pois esta sim pressupõe que o autor (ou titular dos direitos autorais patrimoniais) "aliene"/transfira a outrem a titularidade dos referidos direitos, enquanto a licença de uso nada mais é do que a concessão de autorização para utilização do programa sob determinadas condições.

A corroborar tudo quanto foi dito em relação aos efeitos da cessão, não se pode deixar de mencionar a correspondente doutrina civilista representada por Silvio de Salvo Venosa ${ }^{122}$, para quem os contratos que transferem definitivamente a exploração patrimonial da obra intelectual denominam-se cessão de direitos autorais, enquanto os contratos de transferência temporária são chamados de concessão de direitos autorais.

\footnotetext{
119 Contratos de Direito Autoral, São Paulo: RT, 1989, p. 22.

${ }^{120}$ Contratos, op. cit., p. 62

${ }^{121}$ A Tributação, op. cit., p. 175.

122 Direito Civil: Contratos em Espécie, vol. 3, São Paulo: Atlas, 2005, p. 649.
} 
Além disso, ao tratar da cessão de crédito ${ }^{123}$ - modalidade de transmissão de obrigação prevista nos arts. 286 a 298 do Código Civil - Venosa ${ }^{124}$ esclarece que o crédito como integrante de um patrimônio, possui um valor de comércio, sendo, portanto, passível de comercialização como se "compra e venda" (alienação) fosse. Contudo, o civilista alerta para o fato de que em se tratando de bens imateriais a alienação toma o nome de cessão, o que lhe faz afirmar que a cessão tem pontos de contato com a "compra e venda".

Assim, pode-se dizer que a cessão se equipara a uma alienação, ao passo que a licença se equipara a uma autorização. Portanto, a cessão está para a licença, como a propriedade está para a posse. ${ }^{125}$

\subsection{A licença de uso de programas de computador e suas variações}

Valendo-nos uma vez mais da doutrina de Carlos Alberto Bittar ${ }^{126}$, o autor faz jus aos direitos de utilizar, fruir e dispor da obra, ou autorizar sua utilização ou fruição por terceiros, no todo ou em parte.

O licenciamento do direito de uso do software é ato pelo qual o titular de direitos patrimoniais concede, a título oneroso ou gratuito, por prazo determinado ou indeterminado, exclusivo ou não exclusivo, o direito de usar determinado software. ${ }^{127}$

Mesmo nos casos do software disponibilizado em pacote lacrado, posto à disposição em lojas de departamentos, a figura da "compra e venda" do programa não se perfaz, já que a titularidade do direito não passa para o domínio do adquirente, que recebe apenas uma licença, uma autorização de uso, não podendo dele dispor sem a devida

${ }^{123}$ Segundo Venosa, "na cessão de crédito, o cedente é aquele que aliena o direito; o cessionário, o que adquire. O cedido é o devedor, a quem incumbe cumprir a obrigação. (...) A cessão de crédito é, pois, um negócio jurídico em que o credor transfere a um terceiro seu direito. O negócio jurídico tem feição nitidamente contratual. Nesse negócio, o crédito é transferido intacto, tal como contraído; mantém-se o mesmo objeto da obrigação. Há apenas uma modificação do sujeito ativo" (Teoria Geral das Obrigações e Teoria Geral dos Contratos, São Paulo: Atlas, 2003, p. 330).

${ }^{124}$ Teoria Geral das Obrigações e Teoria Geral dos Contratos, São Paulo: Atlas, 2003, p. 330/359.

${ }^{125}$ Cf. BRANCHER, Paulo Marcos Rodrigues, Contratos, op. cit., p. 33.

${ }^{126}$ Direito, op. cit., p. 52.

${ }^{127}$ Cf. JÚNIOR, Helio Alberto Bellintani, Contrato de licenciamento de uso dos programas de computador destinados à gestão empresarial, Dissertação de Mestrado apresentada à Faculdade de Direito da Pontifícia Universidade Católica de São Paulo, 2003. 
autorização do seu titular (o suporte físico do programa passa para o domínio do adquirente, jamais os direitos sobre a propriedade intelectual do programa). ${ }^{128}$

Renato Lacerda de Lima Gonçalves bem pontua o equívoco em se utilizar a expressão "compra e venda de software":

\begin{abstract}
"De fato, sempre que temos presentes essas duas figuras, titular dos direitos autorais e usuário final, é juridicamente incorreto falar-se em 'aquisição de software' ou em 'compra e venda de software'; trata-se de uma relação de licença de uso de um bem móvel, juridicamente da compra e venda, não apenas porque a lei assim determina em seu artigo $9^{\circ}$ ('o uso de software no Brasil sujeitar-se-á a contrato de licença de uso'), mas também porque esta é a verdadeira intenção das partes.

Se obedecêssemos fielmente às expressões 'aquisição' de software' ou 'compra e venda de software' - contidas em diversos textos a que tivemos acesso, não apenas doutrinários, mas também atos administrativos (principalmente), atos do Poder Legislativo e atos do Poder Judiciário, inclusive originários das mais altas Cortes brasileiras - a cada transação desta espécie (compra e venda, aquisição) envolvendo este tipo de bem móvel, estaríamos diante de uma transmissão dos direitos autorais entre o antigo titular e o novo proprietário, que passaria a ser o titular de todos os direitos de autor que lhe seriam transferidos por força da relação de transferência de propriedade intelectual, não restando ao seu antecessor qualquer direito com relação ao software cujos direitos foram 'vendidos', 'comercializados'.,"129
\end{abstract}

$\mathrm{Na}$ realidade, na maior parte das vezes, o que se pretende dizer com a expressão "comprar um software" é apenas e tão somente "adquirir os direitos de uso de um programa" e a obtenção dos direitos de uso é instituto jurídico que se aproxima muito mais de uma locação, que de uma "compra e venda" propriamente dita. ${ }^{130}$ Nesse sentido, cite-se novamente o entendimento de Renato Lacerda de Lima Gonçalves:

\footnotetext{
"De fato, parece-me que, de uma maneira geral, emprega-se o termo 'locação' quando o uso que se 'licencia' é de um bem corpóreo - como uma casa (bem imóvel) ou um guindaste (bem móvel) - ao passo que o termo 'licença' é utilizado quando o uso que se 'licencia' é de um bem incorpóreo, tal como knowhow, uma marca, um desenho industrial ou um software.

Assim, na primeira hipótese, a relação jurídica existente entre o licenciador do bem corpóreo e seu proprietário é a licença do direito de uso de um bem corpóreo, enquanto que na segunda hipótese, a relação entre licenciador do bem incorpóreo e o seu titular é um direito de propriedade intelectual, um direito autoral (direito real de uso sobre um bem incorpóreo)."131
}

128 Cf. BRANCHER, Paulo Marcos Rodrigues, Contratos, op. cit., p. 63.

129 A Tributação, op. cit., p. 107.

${ }^{130}$ Cf. JUNIOR, Hugo Orrico, Pirataria, op. cit., p. 83.

131 A Tributação, op. cit., p. 107. 
Tecnicamente, quando alguém "vende" um software, vende em caráter definitivo os direitos patrimoniais de exploração comercial do mesmo, inclusive, o código-fonte (o segredo que permite que o programa seja alterado, esmiuçado, copiado, etc.). ${ }^{132}$ Vale lembrar que alguns direitos de autor são inalienáveis (direitos morais).

Quando alguém concede os direitos de uso de um programa de computador, não está realmente "vendendo" o software, mas apenas autorizando, com ou sem exclusividade, por prazo determinado ou não, que o usuário utilize o programa, sem contemplar, obviamente, o direito de revendê-lo, reproduzi-lo ou por qualquer forma alugá-lo sem prévia autorização do titular. ${ }^{133}$

Portanto, existem dois aspectos extremamente importantes no que tange à licença de uso, quais sejam: não há a transferência da titularidade jurídica do bem imaterial, ou seja, não ocorre a transferência da propriedade intelectual do licenciador (autor ou titular de direitos patrimoniais) para o licenciado; e, somente o autor ou o titular dos direitos patrimoniais é que está autorizado a licenciar o uso do software. ${ }^{134}$

É por conta disso que na licença de uso de software o licenciador não autoriza a sua reprodução (salvo, a cópia de segurança) ou fornece ao licenciado o código-fonte (segredo) correspondente. É o código-fonte que permite conhecer como o programa foi elaborado, alterar a sua programação, reproduzi-lo, modificá-lo, etc.

Consoante será tratado mais adiante, a concessão de licença de uso pode ser equiparada a uma "obrigação de dar", pois guarda relação com o consentimento do uso de um bem imaterial.

Quanto à formalização da concessão de licença de uso, qualquer forma de regulamentação escrita que acompanhe os suportes físicos do programa ou sua cópia eletrônica é admitida, desde que esta regulamentação seja feita por escrito e no idioma

\footnotetext{
132 Cf. JUNIOR, Hugo Orrico, Pirataria, op. cit., p. 83.

133 Cf. JUNIOR, Hugo Orrico, Pirataria, op. cit., p. 84 e 133.

134 Cf. GONÇALVES, Renato Lacerda de Lima, A Tributação, op. cit., p. 101/102.
} 
nacional, bastando que o usuário manifeste de qualquer forma, direta ou indireta, a sua aceitação. $^{135}$

Aliás, na ausência de contrato formal de licença de uso, a nota fiscal de aquisição da mídia contendo a cópia do programa faz as vezes da licença e serve como prova da regularidade do uso (art. $9^{\circ}$, parágrafo único, da Lei ${ }^{\circ}$ 9.609/98).

A licença de uso é, portanto, o documento que estabelece os parâmetros, as liberdades, restrições, limites e demais aspectos quanto ao uso. ${ }^{136}$

Muito comum é o contrato de licença de uso denominado em inglês de shrink wrap agreement, que em tradução livre significa contrato encolhido e embalado. Trata-se de contrato por adesão cuja manifestação de vontade se dá de forma tácita (a adesão ocorre mesmo sem a assinatura do usuário). Este contrato de licença de uso, geralmente, acompanha a mídia, o suporte material que contempla a cópia de programa produzido em grandes quantidades e que é posto à disposição dos interessados em lojas de departamento. $^{137}$

Atualmente, ante as inovações tecnológicas, as licenças de uso dos programas de computador produzidos em grandes quantidades ou daqueles que são disponibilizados de forma eletrônica pela internet ${ }^{138}$, são visualizadas no momento em que o usuário faz a sua

135 Cf. JUNIOR, Hugo Orrico, Pirataria, op. cit., p. 82.

136 Cf. BRANCHER, Paulo Marcos Rodrigues, Contratos, op. cit., p. 64

137 Paulo Marcos Rodrigues Brancher sustenta que: "Várias discussões a respeito tomaram início com o surgimento de contrato de licença constantes em uma das faces da embalagem do software. Através desse sistema, o usuário, para vincular-se às condições contratuais, deveria manifestar sua aceitação através da abertura do pacote que envolvia o software. A denominação desse contrato ficou mundialmente conhecida como shrink wrap agreement (em tradução livre, contrato encolhido e embalado) e sua aceitação como tear me open (rasgue-me para abrir). (...) No Brasil, entendemos que, ainda que haja avisos acerca das condições de licença, a aceitação nesse caso não poderia ser configurada no momento da abertura da embalagem, pois esse ato não é suficiente para conceber uma manifestação inequívoca em relação à aceitação do programa em si. Sob esse prisma, já que a aceitação não pode se dar expressamente com a assinatura do licenciado, a forma tácita seria a única possível, desde que propriamente verificada.(...) Embora de efetivo uso no passado, os contratos que imprimem na embalagem os termos e condições da licença de software vêm perdendo espaço para os contratos eletrônicos, passando a constar dentro do próprio programa, com o respectivo acesso ocorrendo durante a sua instalação no hardware" (Contratos, op. cit., p. 64).

138 Segundo Marcos Wachowicz, é palavra do idioma inglês que vem da expressão INTERaction or INTERconnection between computer NETwork (que na tradução livre significa interação ou interconexão entre redes de computadores), e pode ser definida como uma rede de computadores composta de muitas outras redes conectadas entre si por meio de um conjunto de protocolos pertencentes, que permite a 
instalação e com os termos da licença deve anuir expressamente fazendo a opção correspondente sob pena de a instalação do programa não ser concluída.

Helio Alberto Bellintani Júnior ${ }^{139}$ ressalta que a grande maioria dos programas de computador é licenciada com base no número de instalações, ou seja, o adquirente de uma única licença está autorizado a utilizar o programa em um único computador onde esteja o mesmo instalado, não sendo relevante o número de pessoas que utilizem aquele mesmo computador; já os destinados à gestão empresarial, segundo ele, têm o seu licenciamento realizado com base no número de pessoas que acessam o próprio programa, não importando em quantos computadores, na sua maioria grandes servidores de redes internas, estejam instalados.

Consoante esclarece Ana Paula Cotrim da Siqueira ${ }^{140}$, há várias modalidades de licença de uso de programas de computador como, por exemplo, a) a licença para utilizar a integralidade do programa, as suas atualizações e as seus aperfeiçoamentos (conhecidas como licenças full, upgrade e update, respectivamente); b) o licenciamento da versão corrente ou anterior, de modo que a aquisição da licença de determinado programa pressupõe a automática aquisição de licença para o usuário usufruir das suas versões anteriores; c) licença por servidor (mais utilizada por empresas que instalam o software no servidor para que todos os computadores a ele conectados acessem o programa); d) licenciamento por nós que consiste no licenciamento de tantas quantidades quantas bastem para suprir determinadas conexões físicas; e, e) as licenças proporcionais à quantidade de usuário/estações de trabalho (que são as mais comuns).

André Augusto Lins da Costa Almeida ${ }^{141}$ exemplifica outra modalidade de licença, qual seja, a licença individual por número de série como a do Microsoft Office. Segundo ele, a empresa Microsoft criou um pacote contendo vários programas (Word, Microsoft Excel, Microsoft Outlook, Microsoft Access e Microsoft Infopath) e disponibilizou-os conjuntamente em uma mídia com um número de série específico, assim, quando o usuário instala os programas, é obrigado a digitar a chave de acesso do produto (número que o

comunicação, denominado de transmission control protocol/internet protocol (TCP/IP). (Revolução, op. cit., p. 226).

139 Contrato, op. cit., p. 76/77.

140 O Direito, op. cit., p. 39.

${ }^{141}$ Apud, SIQUEIRA, Ana Paula Cotrim, O Direito, op. cit., p. 99. 
diferencia de outros iguais a estes), tendo que validá-la ao final da instalação por telefone ou pela internet.

Renato Lacerda de Lima Gonçalves ${ }^{142}$ propõe outra classificação para o licenciamento do uso dos programas. Para ele, os licenciamentos se dividem em: a) proprietary software, assim entendido como o programa de propriedade de alguém; b) free software, que significa programa livre; e nas seguintes subsespécies: c) freeware, que em tradução livre significa programa gratuito; e, d) shareware, programa compartilhado.

De acordo com o pesquisador: a) o licenciamento de um proprietary software não prevê a disponibilização do código-fonte do programa ao usuário, de modo que estes não têm acesso à tecnologia utilizada na elaboração do programa (não é possível ver e/ou analisar a linguagem natural de sua programação) e, por conta disso, também não é conferida permissão para copiá-lo, alterá-lo ou distribuí-lo; b) o licenciamento de software livre ${ }^{143}$, geralmente é gratuito e a sua maior característica é o livre acesso ao seu códigofonte, ou seja, a linguagem original de sua elaboração é aberta para consulta, o que permite seja o programa alterado, copiado, aprimorado e distribuído; c) o licenciamento do programa freeware é caracterizado por ser sempre gratuito, mas sem permissão de acesso ao respectivo código-fonte, o que impede o seu usuário de copiá-lo, alterá-lo ou distribuílo; e, por fim, d) o programa denominados shareware é, na verdade, programa em modo "demonstração", disponibilizado para que os usuários utilizem-no por determinado período (a título de teste) findo o qual terão de optar por adquirir a respectiva licença que dará acesso ao programa completo.

\section{7 $\quad$ problema do enquadramento do software em classes}

No que tange à classificação dos programas de computador, a doutrina não é uníssona. Para Roberto Chacon de Albuquerque ${ }^{144}$, os programas de computador podem ser divididos em quatro espécies: básico, aplicativo, padronizado e individualizado, os

\footnotetext{
${ }^{142}$ A Tributação, op. cit., p. 149/156.

${ }^{143}$ Gonçalves afirma que as liberdades proporcionadas aos usuários de software livre são: a liberdade de rodar o programa para qualquer propósito; a liberdade de estudar como o programa funciona e adaptá-lo às suas necessidades (o acesso ao código-fonte é uma pré condição a isto); a liberdade de redistribuir cópias de maneira a ajudar o próximo; e, a liberdade de aprimorar o programa e colocar seus aprimoramentos à disposição do público, de maneira que toda a comunidade usufrua. (A Tributação, op. cit., p. 153).

144 ALBUQUERQUE, Roberto Chacon de, A Propriedade, op. cit., p. 37.
} 
quais são diferenciados a partir de características intrínsecas (funcionamento) ou extrínsecas (mercadológicas).

Para o doutrinador, as características intrínsecas dizem respeito ao controle do hardware e à administração e controle do seu funcionamento global, de modo que os programas com estas características classificam-se como básico e aplicativo. Já as características extrínsecas, presentes nos programas padronizados e os individualizados, estão relacionadas com a execução de uma tarefa específica pelo usuário e às questões mercadológicas, ou seja, à capacidade de alguns serem produzidos com vistas a atender às necessidades de um grande número de usuários, enquanto outros têm o seu processo de criação, desenvolvimento e implantação dirigido especificamente para satisfazer os anseios de um cliente específico.

Segundo Albuquerque, os programas básicos, aplicativos, padronizados e individualizados podem ser assim definidos:

\footnotetext{
"Instalados no disco rígido, ou residentes em memória ROM, os softwares básicos são responsáveis pelo gerenciamento das operações fundamentais da máquina, administrando sua gestão interna ao assegurar o encadeamento automático de diferentes tarefas, maximizando o funcionamento do hardware. (...) São responsáveis, por exemplo, pelo tráfego de dados entre os componentes do sistema informático, assegurando a comunicação da CPU com os periféricos, e pelo gerenciamento de arquivos.

Os softwares aplicativos são criados tendo em mente a execução de uma tarefa determinada, como a elaboração de orçamentos, processamento de textos, a solução de cálculos matemáticos. Os softwares aplicativos tiram partido do hardware e do software básico para realizar operações que atendam aos interesses concretos do usuário.

Desenvolvidos tendo em vista uma aplicação específica, são concebidos, no entanto, para satisfazer as necessidades de um número elevado de usuários. São comercializados em grande escala. O software padronizado de um usuário pode ser idêntico ao de outro usuário. Os erros que afetam um exemplar adquirido por um usuário também deverão afetar os outros exemplares do programa. Essa espécie de software costuma servir de importante instrumento de marketing para seus fabricantes.

Os programas personalizados visam a satisfazer as necessidades de usuários específicos. A criação de um software personalizado pressupõe uma íntima colaboração entre o fabricante e o usuário em potencial. Eles definem conjuntamente como o programa será concebido.” 145
}

Os que defendem a classificação acima, muito provavelmente assim o fazem por influência da classificação, que será abordada mais adiante, adotada pelo Supremo Tribunal Federal.

${ }^{145}$ ALBUQUERQUE, Roberto Chacon de, A Propriedade, op. cit., p. 37/40. 
Há quem proponha uma classificação dos programas utilizando como fator de discrímen a forma como são distribuídos. É o que faz Ana Paula Cotrim Siqueira, que os classifica como freeware ${ }^{146}$ (uso gratuito), shareware (uso compartilhado), "prateleira" e software livre.

Consoante defendido por Siqueira, os programas freeware são disponibilizados diretamente pela internet de forma gratuita, o que não lhe afasta da proteção pelo direito autoral. A pesquisadora defende que o fato de serem disponibilizados gratuitamente decorre da própria vontade do seu autor que autoriza o seu uso sem ser remunerado.

Já os da modalidade shareware são programas completos para divulgação mas com bloqueios de execução, pois as suas funções só são liberadas após a aquisição da respectiva licença de uso. ${ }^{147}$

Para Peter Norton ${ }^{148}$, as limitações mais comuns de um programa shareware dizem respeito ao período de uso, que costuma variar entre 30 e 40 dias, tempo suficiente para saber se este agrada ou não ao usuário final. Portanto, o que caracteriza o shareware não é a limitação de funções de uso, mas o fato de ser gratuito por determinado período, findo o qual proporciona ao usuário as opções de registro (obtenção da licença) ou permite o uso com limitações ou lembretes para registrar o programa (obter a licença de uso). ${ }^{149}$

O software de "prateleira" é concebido e elaborado para a generalidade de um determinado perfil de usuário, é gravado em série e não fornece ao consumidor final o direito exclusivo de uso. A formalização dessa forma de contrato ocorre por termo de adesão impresso no interior da embalagem do produto (shrink wrap agreement), com a advertência de que a abertura do envelope implica automaticamente a adesão das condições e cláusulas ${ }^{150}$ do termo. ${ }^{151}$

${ }^{146}$ Alexandre Coutinho Ferrari evidencia que um software de domínio público poderá ser modificado por qualquer um, que passará a ter direitos de autor sobre esse programa, entretanto, o freeware, apesar de gratuito não é um programa de domínio público. Ferrari salienta que essa modalidade de programa é livre para o uso, cópia e distribuição, sendo certo que o usuário não está autorizado a alterá-lo tampouco obriga o programador criador a disponibilizar o código-fonte. (Apud SIQUEIRA, Ana Paula Cotrim, O Direito, op. cit., p. 132).

147 Cf. SIQUEIRA, Ana Paula Cotrim, O Direito, op. cit., p. 141.

148 Apud SIQUEIRA, Ana Paula Cotrim, $O$ Direito op. cit., p. 142.

149 Cf. SIQUEIRA, Ana Paula Cotrim, O Direito, op. cit., p. 141.

${ }^{150}$ Sobre este aspecto, Marcos Wachowicz sustenta que: a) a licença é concedida para a utilização do programa em apenas um computador, sendo proibida a reprodução com exceção da cópia de segurança; 
Para Siqueira, o software livre ${ }^{152}$, assim entendido como o programa que está sob o domínio público, tem o seu código-fonte posto à disposição dos usuários, os quais podem, inclusive, alterá-lo. Sendo assim, trata-se de programa cujo uso não requer obtenção de licença.

No que tange à classificação dos programas em freeware, shareware, "prateleira" e software livre, com o devido respeito, com ela não concordamos, pois não se está a classificar tais bens, mas $\operatorname{sim}$ a forma pela qual estes são disponibilizados/entregues/licenciados ao usuário.

Assim, há quem entenda que não há mais de uma espécie de software, ou seja, que não há razão para classificá-los por não existir variações de espécies. Aires F. Barreto ${ }^{153}$ faz uma crítica a esse respeito ao asseverar que, juridicamente, não existe mais de uma espécie de programa de computador e que não há que se falar em software "de prateleira" (ou cópia única) ou em software adaptado.

Renato Lacerda de Lima Gonçalves ${ }^{154}$ também discorda da existência de uma classificação de programas de computador. Para ele, o que existe são maneiras diferentes pelas quais a permissão de uso do programa se concretiza (que são as espécies de licenciamentos já abordados no item anterior).

Reputamos adequados e coerentes os entendimentos de Barreto e Gonçalves, pois a Lei $n^{\circ} 9.609 / 98$, que rege a matéria, não faz menção a um enquadramento dos programas em classes a partir de determinadas características.

b) o meio físico poderá ser transferido a terceiros mediante cessão de direitos e desde que o usuário final fique obrigado a todos os termos e condições do contrato de adesão; c) o usuário final poderá extinguir unilateralmente o contrato mediante a destruição do meio físico que está em seu poder; d) o titular do programa de computador poderá, em caso de inadimplemento de qualquer obrigação contraída pelo usuário, extinguir a licença de uso, podendo ainda a referida licença ser concedida a prazo determinado ou indeterminado (Apud SIQUEIRA, Ana Paula Cotrim, O Direito, op. cit., p. 130).

151 Cf. SIQUEIRA, Ana Paula Cotrim, O Direito, op. cit., p. 130.

152 Ana Paula Cotrim Siqueira informa que tal programa geralmente é desenvolvido por autor anônimo e que os direitos patrimoniais relacionados com a obra são protegidos pelo Estado pelo prazo de 70 anos, nos termos do art. 24, parágrafo $2^{\circ}$, da Lei 9.610/98 (O Direito, op. cit., p. 135).

153 De acordo com o entendimento do doutrinador, "as expressões 'de prateleira', 'cópia única' e 'customized' são fruto de construção doutrinária e jurisprudencial. A existência jurídica de mais de uma 'espécie' de software seria aceitável apenas e tão-somente se a lei assim o previsse. Ela, todavia não o faz. Assim, a classificação de software em 'software de prateleira' e 'software cópia única', 'software customized' não encontra fundamento legal.” (ISS na Constituição e na Lei. $3^{\mathrm{a}}$ ed. São Paulo: Dialética, 2009, p. 138).

154 A Tributação, op. cit., p. 52. 
Com base na lei, software é a expressão de um conjunto organizado de instruções em linguagem natural ou codificada, contida em suporte físico de qualquer natureza, de emprego necessário em máquinas automáticas de tratamento da informação, dispositivos, instrumentos ou equipamentos periféricos, baseados em técnica digital ou análoga, para fazê-los funcionar de modo e para fins determinados.

Se existem variações, estas estão relacionadas com as várias espécies de licenças de uso que podem ser concedidas e que foram esmiuçadas linhas atrás ou em razão das diversas formas pelas quais os programas podem ser disponibilizados. Tal assertiva nos faz concluir que não há variações de programas (ou seja, o bem é único) e em se tratando de uso, sempre haverá uma licença (autorização) que vinculará o autor (ou aquele que detém os direitos patrimoniais de autor) e o usuário.

Há, ainda, uma outra classificação muito difundida na doutrina e na jurisprudência, que será analisada no próximo item, conhecida como classificação tripartite dos programas de computador nas seguintes espécies: a) standard (padrão) ou "de prateleira"; b) tailormade (que em tradução livre significa sob encomenda); c) híbrido (também conhecido em inglês como customized, que em tradução livre, significa adaptável).

Renato Lacerda de Lima Gonçalves ${ }^{155}$ faz um apontamento crítico quanto à utilização desregrada das expressões software "de prateleira", "standard", "cópia única" e “customized", por entender que não se tratam de classes ou categorias de programas, mas sim de classificação das relações econômicas que se instauram entre as partes: autor/titular dos direitos autorais patrimoniais e o usuário.

Tal crítica é acertada, pois a lei apenas define o que é software, sem dar margem à possíveis classificações, motivo pelo qual concordamos com o entendimento doutrinário segundo o qual não é adequado classificar os programas de computador para assim impor determinado regramento jurídico-tributário às relações que têm por objeto a licença de uso.

${ }^{155}$ A Tributação, op. cit., p. 76. 


\subsection{A classificação tripartite de espécies de software adotada pelo Supremo Tribunal Federal (RE $\mathbf{n}^{0}$ 176.626-3/SP)}

Ao esmiuçar as questões controvertidas da tributação do uso de programas de computador, nos deparamos com a frequente utilização de uma classificação que, uma vez adotada pelo Supremo Tribunal Federal, ganhou evidência não apenas na jurisprudência, como também na doutrina.

Ao julgar o Recurso Extraordinário no $176.626-3$, que versava sobre a incidência ou não do ICMS sobre as operações com software padrão disponibilizado em lojas de departamento, o STF acolheu a classificação tripartite de programas de computador defendida por Rui Saavedra em monografia ${ }^{156}$ acadêmica apresentada à Universidade de Coimbra.

De acordo com o citado acadêmico, os programas de computador são classificados em 3 categorias postas a partir do grau de padronização. São elas: (i) software padrão; (ii) software desenvolvido sob encomenda; e, (iii) software adaptado ao cliente.

Nos termos da referida decisão, Rui Saavedra defende que os programas "padrão" são bem definidos, estáveis, concebidos para serem dirigidos a uma pluralidade de usuários (e não a um usuário específico) e desempenham a mesma função/utilidade. São concebidos para tratamento das necessidades de uma mesma categoria de usuários como, por exemplo, a contabilidade de um escritório de advogados, mas possibilitam uma configuração adequada para que cada um encontre solução/utilidade para a sua realidade específica (são os "esqueletos" a que faltam o "revestimento muscular", diz ele). São produtos acabados, produzidos em massa, em grandes quantidades, que podem ser utilizados em diferentes equipamentos, são vocacionados a um vasto público e, até, comercializados em grandes lojas de departamento e supermercados e por este motivo também são denominados de software "de prateleira". A título de exemplo, cite-se, o Pacote Office da Microsoft.

Os programas desenvolvidos sob encomenda são construídos a partir das exigências do seu encomendante, de modo a satisfazer as suas necessidades. Para o mencionado

\footnotetext{
${ }^{156}$ A Proteção Jurídica do Software e a Internet, Lisboa: Don Quixote, 1998.
} 
doutrinador, são programas aplicacionais que geralmente não se mantém estáveis e acabados como os programas "padrão"; tal espécie é continuamente adaptada, corrigida e melhorada para responder aos requisitos internos e externos das empresas.

Os programas adaptados ao cliente, por sua vez, constituem uma forma híbrida entre os programas padrão e os que são produzidos sob encomenda. Segundo Saavedra, eles baseiam-se nos primeiros, mas são modificados para se adequarem às necessidades de determinado cliente.

Ele defende que nas relações com os clientes, a empresa produtora do software surge como proprietária do programa que ela cria e comercializa, quer se trate de programa padrão ou daquele produzido sob encomenda, pois mesmo neste último caso a propriedade do programa permanece - habitualmente - na titularidade ${ }^{157}$ da empresa que o desenvolveu, diz ele.

Diferentemente sucede nas relações com o usuário do programa padrão, pontua Saavedra, já que tal software é comercializado junto de uma clientela potencialmente vasta, de modo que a propriedade do software em si nunca é transferida ao usuário, mas apenas o direito de uso não exclusivo é concedido, mediante contrato por adesão firmado ainda que tacitamente entre o titular dos direitos autorais sobre o programa e o usuário, cujas cláusulas limitam a liberdade do usuário, impedem que o programa seja copiado/reproduzido, que seja utilizado/instalado em mais de um computador, que seja alugado, decomposto, etc.

A despeito de não concordarmos com a classificação adotada pelo STF, já que a referida classificação não está a classificar o bem, mas a forma como o autor do programa pactua com o usuário/cliente interessado, vamos utilizá-la ao longo deste trabalho, motivo pelo qual as definições de cada "espécie", acolhidas pela Suprema Corte, precisam estar bem claras.

\footnotetext{
${ }^{157}$ No Brasil, nos termos do art. $4^{\circ}$, da Lei $\mathrm{n}^{\circ}$ 9.609/98, salvo estipulação em contrário, pertencerão exclusivamente ao contratante, os direitos relativos ao programa de computador, desenvolvido e elaborado durante a vigência de contrato. Em face dos altíssimos custos envolvidos com o desenvolvimento de um software, é comum o contratante solicitar que lhe seja cedida a propriedade do programa.
} 


\subsection{A diferença entre o software e o seu suporte material}

Os bens distinguem-se conforme suas características físicas em: bens materiais, perceptíveis pelos sentidos e imateriais, criações da mente, concebidas de forma abstrata. A categoria dos imateriais não dispõe de limites e características próprias e o único elemento constante é a ausência da matéria ou corpo, muito embora possam ser materializados para serem apreciados, contemplados, percebidos, manuseados, etc., como, por exemplo, o modelo industrial, a invenção, o know-how, o programa do computador, etc. $^{158}$

José de Oliveira Ascensão ${ }^{159}$ argumenta que o programa de computador normalmente requer uma materialização em meio físico e que o programa não pode ser confundido com o suporte material em que é incorporado, já que aquele não está preso a uma apresentação física determinada.

São ontológicas as diferenças entre programa de computador (bem imaterial corpus mysticum) e o seu suporte físico (bem material - corpus mechanicum) ${ }^{160} \mathrm{e}$ considerando que o regime jurídico (de proteção, inclusive) aplicável a cada um deles é distinto, há que se compreender com clareza tais diferenças.

Sílvio de Salvo Venosa ${ }^{161}$ entende que em se tratando de direitos intelectuais, o aspecto material, presente no corpus mechanicum, se mantém exclusivamente na esfera patrimonial enquanto não divulgado o resultado da obra intelectual (como, por exemplo, pela publicação do livro, pela exposição da escultura, da película, da peça teatral, do programa de computador, etc.). A obra intelectual, por sua vez, segundo ele, identifica-se com o corpus mysticum, bem não corpóreo, pertencente ao patrimônio do autor que, uma vez divulgado, passa a integrar o patrimônio da coletividade como bem cultural.

O binômio corpus mechanicum e corpus mysticum torna-se evidente no programas de computador. A relação do software com o seu suporte material supõe uma relação

\footnotetext{
158 Cf. PAESANI, Liliana Minardi, Direito, op. cit., p. 23.

159 Direito, op. cit., p. 665.

160 Cf. PAESANI, Liliana Minardi, Direito, op. cit., p. 24.

161 Direito Civil: Contratos em Espécie, vol. 3, São Paulo: Atlas, 2005, p. 647/648.
} 
análoga a qualquer outra obra de engenho com suporte de papel ou de outra natureza. ${ }^{162} \mathrm{O}$ fato de o programa estar contido em um suporte físico, bem corpóreo, não altera a sua natureza de bem imaterial, incorpóreo, equiparado à obra intelectual, protegida pelo Direito Autoral.

Em outras palavras, não obstante a intrínseca relação que há entre o programa e o seu suporte físico, que em alguns casos é indispensável, o software (enquanto obra intelectual, fruto da criatividade humana) apenas se materializa em uma mídia que nada mais é do que um veículo que proporciona a sua divulgação na sociedade. ${ }^{163}$

Inclusive, para as empresas que desenvolvem programas, o suporte material é concebido como bem material autônomo e é equiparado ao hardware quanto às garantias aplicáveis nas relações contratuais. ${ }^{164}$

E, por assim dizer, o fato de o software ser armazenado num disquete, num disco rígido ou numa memória ROM, ou qualquer outro suporte, não deveria ensejar repercussão jurídica. Contudo, consoante se verá mais adiante, na seara do direito tributário, por exemplo, a discussão ganha grandes proporções, daí a preocupação em distinguir o programa do seu suporte material.

O suporte físico que materializa o programa de computador é apenas um dos meios pelos quais o bem imaterial é levado e posto à disposição dos interessados em utilizá-lo. Aliás, atualmente, já é possível distribuir e/ou entregar o software por outros meios como, por exemplo, por download. Contudo, o suporte material, móvel, que permite que o bem imaterial seja individualizado e transportado de um local para outro, ainda é a forma mais usual.

Portanto, a depender do usuário e da configuração do programa de computador, a sua materialização em meio físico se torna indispensável, o que não desnatura a sua natureza jurídica. Neste caso, o suporte físico ainda mantém o seu caráter acessório,

\footnotetext{
${ }^{162}$ Cf. PAESANI, Liliana Minardi, Direito, op. cit., p. 24.

${ }^{163}$ Cf. ALBUQUERQUE, Roberto Chacon de, A Propriedade, op. cit., p. 45/46.

164 Cf. PAESANI, Liliana Minardi, Direito, op. cit., p. 24.
} 
viabilizando da mesma forma o acesso à obra intelectual, mesmo que seja considerado indispensável.

\title{
2.10 A diferença entre software e conteúdo digital
}

Em que pese o conteúdo digital não ser determinante para o presente estudo, a fim de assegurar a mais perfeita compreensão sobre software, há que se diferenciar este daquele. Para tanto, nada melhor que a passagem abaixo, em que Bill Gates discorre sobre os avanços tecnológicos dos quais desfrutamos nos dias atuais:

\begin{abstract}
"A superestrada da informação ${ }^{165}$ vai possibilitar inovações na maneira pela qual a propriedade intelectual, tal como música e software, é licenciada. Gravadoras e até mesmo artistas independentes podem optar por vender música de uma nova maneira. Você, o consumidor, não necessitará de CDs, fitas ou qualquer outra espécie de aparato físico.

A música será armazenada em bits de informação em um servidor da superestrada. 'Comprar' uma canção ou um disco na realidade significará comprar o direito de acessar os bits apropriados. Você poderá ouvir em casa, no escritório, ou em férias, sem a necessidade de carregar uma coleção de títulos. Qualquer lugar onde você vá em que existam caixas acústicas conectadas à superestrada, permitirá a você identificar-se e usufruir de seus direitos. Você não poderá alugar uma sala de concerto e executar a gravação da música ou criar um anúncio que a utilize. Mas em uma situação não comercial, em qualquer lugar que você vá, você terá o direito de tocar a música sem necessidade de realizar um pagamento adicional ao titular dos direitos autorais. Da mesma maneira, a superestrada da informação poderá rastrear se você comprou o direito de ler um determinado livro ou de ver um filme. Se você o fez, você será capaz de fazê-lo a qualquer momento, a partir de qualquer dispositivo de informação em qualquer lugar." 166
\end{abstract}

165 José de Oliveira Ascensão, sob outra perspectiva, propõe a seguinte definição: "Na base da sociedade da informação está o veículo ou a infra-estrutura, representada pelo que se chama, noutra imagem igualmente ambiciosa, as 'auto-estradas da informação'. Os meios técnicos permitiram ampliar extraordinariamente as potencialidades de comunicação. A utilização da fibra óptica viabiliza que muito mais mensagens sejam transmitidas. $O$ incremento da capacidade e da velocidade de comunicação permite grandes progressos no domínio da interatividade. Até há um modelo em que todos possam entrar em contato com todos, deixando de ser receptores passivos. Surge a noção de rede. As redes unem computadores. Pode haver uma rede num escritório. Mas um grupo de redes pode ser unificado. A interconexão das redes nacionais formaria a Intranet. Transposto o esquema para o meio internacional, temos o modelo da Internet, que funciona como a rede das redes mundiais. A comunicação de todos com todos vai ser assegurada pelas auto-estradas da informação (ou da comunicação) que são meios de comunicação direta entre computadores. Permitem, aliás, reunir numa só linha e num só aparelho todos os serviços até hoje separados - fax, telefone, computação, televisão. Ao contrário da radiodifusão, em que havia comunicação de um ponto para muitos pontos, mas não vice-versa; e do telefone, em que havia comunicação ponto a ponto; pretende-se agora a comunicabilidade de todos os pontos para todos os pontos." (Direito, op. cit., p. 681).

166 Apud GONÇALVES, Renato Lacerda de Lima, A Tributação, op. cit., p. 53/54. 
Consoante esclarece Renato Lacerda de Lima Gonçalves ${ }^{167}$, quando ouvimos uma música pelo alto falante do computador, essa reprodução sonora nada mais é do que a informação processada a partir de dados contidos em arquivo, interpretados pelo computador de acordo com instruções fornecidas pelo software correspondente, fazendo com que os impulsos elétricos sejam enviados ao alto falante, que por sua vez faz vibrar uma superfície em frequências tais que os sons originalmente digitalizados são reproduzidos.

Segundo o pesquisador, o processador é instruído pelo software a fazer alguma coisa (produzir determinada frequência audível por meio do alto falante) a partir de dados dos arquivos, isto é, a partir do conteúdo. O arquivo (conteúdo) contém dados, que são transformados em informações (sons ou imagens) por meio da ação do processador, instruído pelo software.

Portanto, pode-se dizer que conteúdo digital corresponde a textos, sons, imagens e banco de dados armazenados digitalmente dentro de um computador ou em outro suporte físico informático qualquer, fruto do espírito criativo humano, criado ou convertido em formato eletrônico por meio do emprego de um computador e de um software. ${ }^{168}$

Tal distinção é importante não só para tornar clara a definição de software, mas também para distanciá-la da celeuma sobre a imunidade dos programas de computador arguida pela doutrina ${ }^{169}$, por equiparação à imunidade conferida aos livros, jornais, periódicos e o papel destinado à sua impressão (art. 150, VI, “d”, da Constituição Federal), bem como para diferenciar as situações que envolvem outros bens intelectuais como, por exemplo, a aquisição de um livro - seja ele em papel ou digital - e a obtenção de um programa de computador.

Muito embora não seja objeto do presente estudo e por isso não aprofundaremos a questão, não acreditamos que os programas de computador propriamente ditos gozem da imunidade em relação aos impostos, prevista no art. 150, VI, “d”, da Constituição Federal.

${ }^{167}$ GONÇALVES, Renato Lacerda de Lima, A Tributação, op. cit., p. 56.

168 Cf. GONÇALVES, Renato Lacerda de Lima, A Tributação, op. cit., p. 56.

169 Neste sentido posiciona-se Edvaldo Brito (Software: ICMS, ISS ou Imunidade Tributária?, Revista Dialética de Direito Tributário, $n^{o}$. 5, São Paulo: Dialética, 1996, p. 19). 
Isso porque, a incompetência ${ }^{170}$ dos entes federados para tributar os livros, os jornais, os periódicos e o papel destinado a sua impressão objetivou garantir a liberdade de expressão, a livre manifestação do pensamento e da comunicação.

Nas palavras de Tércio Sampaio Ferraz Junior ${ }^{171}$, a referida imunidade visa a resguardar a liberdade de informar e ser informado.

Ao contrário do que ocorre com os livros, jornais, periódicos, etc., os programas de computador em si considerados não fomentam a divulgação do saber; eles viabilizam-na. Fomentariam o saber e a divulgação de conhecimentos científicos, por exemplo, se os respectivos códigos-fonte pudessem ser acessados livremente, o que conforme visto, nem sempre é possível. ${ }^{172}$

É certo que em 1988 não era possível antever os avanços tecnológicos e o formato dos veículos de comunicação do século XXI. É compreensível, portanto, a razão pela qual o texto constitucional não menciona outras tecnologias que proporcionam a liberdade de expressão e do saber da mesma forma que o papel.

Apenas a título de esclarecimento, compartilhamos do entendimento segundo o qual a imunidade não alberga apenas o livro em papel, mas também livros em outros formatos, pois o constituinte imunizou o valor contido no livro, por ser um instrumento do saber, da cultura, da pesquisa, da divulgação de ideias e, acima de tudo, um instrumento à serviço da liberdade de expressão e da democracia.

Em relação à distinção entre o software e outros bens intelectuais, notadamente as obras literárias, estejam elas em papel ou em meio digital, a distinção - a nosso ver - está

${ }^{170}$ Cf. Para Misabel Abreu Machado Derzi: "podemos conceituar as imunidades como regra expressa da Constituição (ou implicitamente necessária), que estabelece a não-competência das pessoas políticas da Federação para tributarem certos fatos e situações, de forma amplamente determinada, delimitando negativamente, por meio de redução parcial, a norma de atribuição de poder tributário." (comentários à obra de Aliomar Baleeiro, Limitações Constitucionais ao Poder de Tributar, $7^{\mathrm{a}}$ ed. Rio de Janeiro: Forense, 1997, p. 16).

${ }^{171}$ Livro Eletrônico e Imunidade Tributária, Cadernos de Direito Tributário e de Finanças Públicas, vol. 22, 1998 , p. 32/38.

172 Neste aspecto, vale lembrar que há software cujos códigos-fonte são disponibilizados ao público em geral; estes permitem e dão ensejo à divulgação de conhecimentos tecnológicos. 
no caráter utilitário de elevado valor agregado daquele, marcado por proporcionar o acionamento de máquinas e o manejo eletrônico de dados.

A despeito de ambos serem bens intelectuais, sendo o software, inclusive, equiparado às obras literárias, se o ser humano pudesse ver, compreender e fazer uso dos dígitos binários (a sequência de "zeros" e "uns") que o compõem, até admitiríamos o programa de computador como um conteúdo digital integralmente equivalente a um livro em formato digital, por exemplo.

Aliás, é curioso como o livro em papel somente é convertido para o formato digital com a utilização de determinado software que aliado ao hardware transforma os bytes em textos (imagens, sons, etc.) sensíveis à percepção humana (à visão).

Um conjunto de folhas brancas não é reconhecido como um livro, mas as mesmas folhas marcadas com palavras indeléveis ou em braile são reconhecidas pelo ser humano como tal e também o são, a nosso ver, se a mesma obra intelectual for convertida para o formato digital, já que também será perceptível pelo sentido humano e desempenhará a mesma função da sua versão tradicional em papel. ${ }^{173}$

Reconhecemos que o livro em formato digital e o software são conteúdos digitais, assim considerados em sentido lato sensu, contudo, não obstante os pontos de contato que os assemelham, as suas diferenças precisam ser consideradas e respeitadas.

${ }^{173}$ CEZAROTI, Guilherme, Incidência do ICMS sobre as operações internas e interestaduais de vendas de mercadorias realizadas eletronicamente, Dissertação de Mestrado apresentada à Faculdade de Direito da Universidade de São Paulo, 2004, p. 70. 


\section{IMPOSTO SOBRE OPERAÇÕES RELATIVAS À CIRCULAÇÃO DE MERCADORIAS E SOBRE PRESTAÇÕES DE SERVIÇOS DE TRANSPORTE INTERESTADUAL E INTERMUNICIPAL E DE COMUNICAÇÃO}

\subsection{Histórico legislativo}

Em primoroso trabalho que resultou em tese de livre-docência apresentada à Faculdade de Direito da Universidade de São Paulo, o Professor Alcides Jorge Costa ${ }^{174}$ relata que a difusão dos impostos sobre vendas ocorreu após a $1^{\mathrm{a}}$ Guerra Mundial, quando países como a França e a Alemanha, premidos por dificuldades financeiras, valeram-se deste tipo de tributo em razão de proporcionar elevada arrecadação.

No Brasil, ressalta o doutrinador, "o Decreto $\mathrm{n}^{\circ} 4.505$, de 31 de dezembro de 1870 , regulamentou a cobrança do imposto do selo incidente sobre 'letras de câmbio e de terra, escritos à ordem, créditos e escrituras de títulos e ordem de obrigação ou exoneração de somas de valores' e declarou compreenderem-se nesta classe 'créditos, faturas ou contas assinadas'.,175

Tem-se, portanto, que o imposto do selo (que detinha a natureza de imposto de vendas) incidia sobre as faturas e não sobre a compra e venda propriamente dita. ${ }^{176}$

Ainda de acordo com o rico histórico legislativo desenhado por Alcides Jorge Costa, o advento da Lei $\mathrm{n}^{\mathrm{o}} 2.044$ de 1908, que definiu a letra de câmbio e a nota promissória e regulou as operações cambiais, acarretou o desuso das contas assinadas (faturas) por não terem sido arroladas entre os títulos cambiais, o que - consequentemente - ensejou a diminuição da ocorrência de fatos gravados com o imposto do selo. ${ }^{177}$

Atendendo aos anseios dos comerciantes da época, o Poder Legislativo editou a Lei $\mathrm{n}^{\mathrm{o}} 2.919$, de 1914, e autorizou a cobrança do citado imposto e a equiparação da fatura à

\footnotetext{
${ }^{174}$ ICM - Estrutura na Constituição e na Lei Complementar, Tese de livre-docência apresentada à Faculdade de Direito da Universidade de São Paulo, 1977, p. 2.

175 ICM, op. cit., p. 2.

176 Cf. COSTA, Alcides Jorge, ICM, op. cit., p. 2.

177 Cf. COSTA, Alcides Jorge, ICM, op. cit., p. 3.
} 
letra de câmbio e notas promissórias. Contudo, no ano seguinte a lei foi revogada e somente em 1922, por meio da Lei $\mathrm{n}^{\circ} 4.625$, é que foi autorizada a exigência do referido imposto sobre as vendas mercantis, a prazo ou à vista.

A partir daí, outras normas foram editadas até que sobreveio o Decreto $\mathrm{n}^{\circ}$ 22.061/32, que instituiu o imposto sobre vendas mercantis que era de competência da União e vigorou até a promulgação da Constituição Federal de 1934, cujo art. $8^{\text {o178 }}$ passou a prever o imposto sobre vendas e consignações (IVC) de competência estadual e também cumulativo $^{179}$.

Ao alterar a Constituição de 1946, a Emenda Constitucional no 18/65 (art. 12 ${ }^{180}$ ), dentre outras coisas, outorgou competência aos Estados para instituírem o imposto sobre operações relativas à circulação de mercadorias, realizadas por comerciantes, industriais e produtores (ICM), ordenou a sua não-cumulatividade e excetuou da sua incidência as

178 “Art . $8^{\circ}$ - Também compete privativamente aos Estados:

I - decretar impostos sobre:

a) propriedade territorial, exceto a urbana;

b) transmissão de propriedade causa mortis ;

c) transmissão de propriedade imobiliária inter vivos, inclusive a sua incorporação ao capital da sociedade;

d) consumo de combustíveis de motor de explosão;

e) vendas e consignações efetuadas por comerciantes e produtores, inclusive os industriais, ficando isenta a primeira operação do pequeno produtor, como tal definido na lei estadual;

f) exportação das mercadorias de sua produção até o máximo de dez por cento ad valorem, vedados quaisquer adicionais;

g) indústrias e profissões;

h) atos emanados do seu governo e negócios da sua economia ou regulados por lei estadual;

II - cobrar taxas de serviços estaduais.

$\S 1^{\circ}$ - O imposto de vendas será uniforme, sem distinção de procedência, destino ou espécie dos produtos.

$\S 2^{\circ}-\mathrm{O}$ imposto de indústrias e profissões será lançado pelo Estado e arrecadado por este e pelo Município em partes iguais.

$\S 3^{\circ}$ - Em casos excepcionais, o Senado Federal poderá autorizar, por tempo determinado, o aumento do imposto de exportação, além do limite fixado na letra $f$ do número I.

$\S 4^{\circ}$ - O imposto sobre transmissão de bens corpóreos, cabe ao Estado em cujo território se acham situados; e o de transmissão causa mortis, de bens incorpóreos, inclusive de títulos e créditos, ao Estado onde se tiver aberto a sucessão. Quando esta se haja aberto no exterior, será devido o imposto ao Estado em cujo território os valores da herança forem liquidados, ou transferidos aos herdeiros."

179 Segundo Alcides Jorge Costa, tratava-se de imposto multifásico, incidente "em cascata", ou seja, incidente sobre cada venda, em todas as fases da circulação das mercadorias, desde a fonte produtora até o consumidor (ICM, op. cit., p. 3).

180 “Art. 12. Compete aos Estados o impôsto sôbre operações relativas à circulação de mercadorias, realizadas por comerciantes, industriais e produtores.

$\S 1^{\circ}$ A alíquota do impôsto é uniforme para tôdas as mercadorias, não excedendo, nas operações que as destinem a outro Estado, o limite fixado em resolução do Senado Federal, nos têrmos do disposto em lei complementar.

$\S 2^{\circ} \mathrm{O}$ impôsto é não-cumulativo, abatendo-se, em cada operação, nos têrmos do disposto em lei complementar, o montante cobrado nas anteriores, pelo mesmo ou por outro Estado, e não incidirá sôbre a venda a varejo, diretamente ao consumidor, de gêneros de primeira necessidade, definidos como tais por ato do Poder Executivo Estadual." 
vendas a varejo e gêneros de primeira necessidade (definidos em ato do Poder Executivo Estadual).

Alcides Jorge Costa ${ }^{181}$ relata que o ICM não entrou com sua estrutura pronta e acabada no sistema tributário nacional e que seus princípios básicos foram lançados na EC $n^{\circ} 18 / 65^{182}$ e no CTN, mas que sofreram alterações na tumultuada legislação subsequente, antes mesmo do imposto ser exigido pelos Estados e que só a partir da EC nº 1/69 (à Constituição de 1967) é que começou a estabilizar-se.

Sobre o contexto histórico, Sacha Calmon Navarro Coêlho assevera que "à época do movimento militar de 1964, receptivo às críticas dos juristas e economistas que viam no imposto sobre vendas e consignações (IVC) um tributo avelhantado, 'em cascata', propiciador de inflação, verticalizador da atividade econômica, impeditivo do desenvolvimento da Federação e tecnicamente incorreto, resolveu-se substituí-lo por um imposto 'não-cumulativo' que tivesse como fatos geradores não mais 'negócios jurídicos', mas a realidade econômica das operações promotoras da circulação de mercadorias e serviços, no país, como um todo". ${ }^{183}$

Sacha Calmon Navarro Coêlho ${ }^{184}$ também informa que "a idéia era tomar como modelo os impostos europeus sobre valores agregados ou acrescidos, incidentes sobre bens e serviços de expressão econômica, os chamados IVAs", que eram aplicados em Estados unitários e eram de competência do Poder Central.

Alcides Jorge Costa pontua que a criação do ICM, em substituição ao IVC, deu-se em razão dos problemas e prejuízos causados pela incidência cumulativa do imposto:

181 ICM, op. cit., p. VII (introdução).

182 Em relação à $\mathrm{EC} \mathrm{n}$ ' 18/65, Alcides Jorge Costa relembra que: “A substituição do imposto sobre vendas e consignações pelo ICM não foi submetida a debate amplo, mesmo porque não houve - ou não foi dado tempo para fazê-lo. A comissão encarregada de elaborar o anteprojeto de reforma da discriminação constitucional de rendas foi constituída pela Portaria GB-30, de 27 de janeiro de 1965, do Ministro da Fazenda. Em 18 de junho do mesmo ano, portanto antes de decorridos seis meses, a Comissão entregava um anteprojeto de emenda constitucional dividido em duas proposituras, designadas A e B. Com algumas modificações introduzidas pelos Ministros da Fazenda e do Planejamento, o projeto revisto da Emenda B foi encaminhado ao Congresso Nacional pelo Presidente da República, com a mensagem n. 21, de 4 de novembro de 1965. Menos de um mês depois, o Congresso Nacional aprovou o projeto que se converteu na Emenda Constitucional n. 18, de 1 de dezembro de 1965; a Emenda A não foi submetida ao Congresso Nacional. A Constituição de 1967 e a Emenda Constitucional 1/69, conservaram o ICM, tal como implantado pela Emenda n. 18." (ICM, op. cit., p. 4).

183 Curso de Direito Tributário Brasileiro, Rio de Janeiro: Forense, 2011, p. 310.

${ }^{184}$ Curso, op. cit., p. 310. 


\begin{abstract}
"Estas vantagens são compensadas por desvantagens que o legislador teve em mente ao introduzir o tipo do valor acrescido. Assim é que o Relatório com que a Comissão encarregada de elaborar o anteprojeto de reforma tributária encaminhou sua proposta ao ministro da Fazenda diz que é característica moderna dos impostos sobre a circulação, primeiro elaborada na França e imitada pela maioria dos países, a de só tributarem, em cada sucessiva operação, o valor acrescido, eliminando-se assim os notórios malefícios econômicos da superposição em cascata, de incidência repetidas sobre bases de cálculo cada vez mais elevadas pela adição de novas margens de lucro, de novas despesas acessórias, e do próprio imposto que recaiu sobre as operações anteriores."185
\end{abstract}

Contudo, no Brasil, um Estado Federado que não estava familiarizado com a nãocumulatividade, foi preciso implementar algumas alterações na concepção originária de criar um imposto pautado no modelo europeu de valor agregado (IVA).

Por esse motivo adequada é a ponderação de Sacha Calmon Navarro Coêlho ${ }^{186}$ para quem o "confronto entre concepções teóricas e a realidade deu origem a um imposto problemático tomado de enfermidades descaracterizantes". 187

O imposto sobre operações relativas à circulação de mercadorias e sobre prestações de serviços de transporte interestadual e intermunicipal e de comunicação (ICMS) tal qual é conhecido hoje, é o sucessor dos antigos impostos sobre vendas e consignações (IVC) e sobre operações relativas à circulação de mercadorias (ICM).

Com a promulgação da Constituição Federal de 1988, o constituinte outorgou competência aos Estados e ao Distrito Federal para instituírem o ICMS, nos termos do art. 155 , II, $\S 2^{\circ}$, I ao XII:

“Art. 155. Compete aos Estados e ao Distrito Federal instituir impostos sobre:

(...)

185 ICM, op. cit., p. 3 e 4.

186 Curso, op. cit., p. 310.

${ }^{187}$ Esses mesmos problemas são apontados por Sacha Calmon Navarro Coêlho em relação ao ICMS, confira-se: "Em primeiro lugar, a uniformidade das alíquotas, outra característica do imposto na ideação dos seus fautores, o que, em tese, devia afastar qualquer veleidade extrafiscal ou de seletividade, como muito bem observado pelo Professor Ruy Barbosa Nogueira, desandou em diversas alíquotas (desuniformes, portanto) para atender aos reclamos da participação de arrecadação entre 'estados industrializados' e 'estados consumidores'. Surgiram, então, alíquotas internas, alíquotas de exportação e alíquotas interestaduais e, nestas últimas, alíquotas diferenciadas para operações que destinassem mercadorias para o centro-sul ou para o norte-nordeste. (...) Em segundo lugar, a 'neutralidade' do ICMS tornou-se mera peça de retórica. Através de isenções heterônomas, a União Federal utilizou à larga o ICMS como instrumento de política econômica. E, mediante o mecanismo dos 'convênios', transformados em 'Assembléias Legislativas de Estados Federados', sob o guante autoritário da União (o famoso CONFAZ), o imposto tornou-se, largamente, um tributo extrafiscal, gerando disfunções com atrozes perdas de receita para os estados." (Curso, op. cit., p. 313). 
II - operações relativas à circulação de mercadorias e sobre prestações de serviços de transporte interestadual e intermunicipal e de comunicação, ainda que as operações e as prestações se iniciem no exterior;

(...)

$\S 2 .^{\circ} \mathrm{O}$ imposto previsto no inciso II atenderá ao seguinte:

I - será não-cumulativo, compensando-se o que for devido em cada operação relativa à circulação de mercadorias ou prestação de serviços com o montante cobrado nas anteriores pelo mesmo ou outro Estado ou pelo Distrito Federal;

II - a isenção ou não-incidência, salvo determinação em contrário da legislação:

a) não implicará crédito para compensação com o montante devido nas operações ou prestações seguintes;

b) acarretará a anulação do crédito relativo às operações anteriores;

III - poderá ser seletivo, em função da essencialidade das mercadorias e dos serviços;

IV - resolução do Senado Federal, de iniciativa do Presidente da República ou de um terço dos Senadores, aprovada pela maioria absoluta de seus membros, estabelecerá as alíquotas aplicáveis às operações e prestações, interestaduais e de exportação;

V - é facultado ao Senado Federal:

a) estabelecer alíquotas mínimas nas operações internas, mediante resolução de iniciativa de um terço e aprovada pela maioria absoluta de seus membros;

b) fixar alíquotas máximas nas mesmas operações para resolver conflito específico que envolva interesse de Estados, mediante resolução de iniciativa da maioria absoluta e aprovada por dois terços de seus membros;

VI - salvo deliberação em contrário dos Estados e do Distrito Federal, nos termos do disposto no inciso XII, "g", as alíquotas internas, nas operações relativas à circulação de mercadorias e nas prestações de serviços, não poderão ser inferiores às previstas para as operações interestaduais;

VII - em relação às operações e prestações que destinem bens e serviços a consumidor final localizado em outro Estado, adotar-se-á:

a) a alíquota interestadual, quando o destinatário for contribuinte do imposto;

b) a alíquota interna, quando o destinatário não for contribuinte dele;

VIII - na hipótese da alínea "a" do inciso anterior, caberá ao Estado da localização do destinatário o imposto correspondente à diferença entre a alíquota interna e a interestadual;

IX - incidirá também:

a) sobre a entrada de bem ou mercadoria importados do exterior por pessoa física ou jurídica, ainda que não seja contribuinte habitual do imposto, qualquer que seja a sua finalidade, assim como sobre o serviço prestado no exterior, cabendo o imposto ao Estado onde estiver situado o domić́lio ou o estabelecimento do destinatário da mercadoria, bem ou serviço;

b) sobre o valor total da operação, quando mercadorias forem fornecidas com serviços não compreendidos na competência tributária dos Municípios;

X - não incidirá:

a) sobre operações que destinem mercadorias para o exterior, nem sobre serviços prestados a destinatários no exterior, assegurada a manutenção e $\quad$ aproveitamento do montante do imposto cobrado nas operações e prestações anteriores;

b) sobre operações que destinem a outros Estados petróleo, inclusive lubrificantes, combustíveis líquidos e gasosos dele derivados, e energia elétrica;

c) sobre o ouro, nas hipóteses definidas no art. $153, \S 5^{\circ}$;

d) nas prestações de serviço de comunicação nas modalidades de radiodifusão sonora e de sons e imagens de recepção livre e gratuita;

XI - não compreenderá, em sua base de cálculo, o montante do imposto sobre produtos industrializados, quando a operação, realizada entre contribuintes e relativa a produto destinado à industrialização ou à comercialização, configure fato gerador dos dois impostos;

XII - cabe à lei complementar:

a) definir seus contribuintes;

b) dispor sobre substituição tributária; 
c) disciplinar o regime de compensação do imposto;

d) fixar, para efeito de sua cobrança e definição do estabelecimento responsável, o local das operações relativas à circulação de mercadorias e das prestações de serviços;

e) excluir da incidência do imposto, nas exportações para o exterior, serviços e outros produtos além dos mencionados no inciso X, "a";

f) prever casos de manutenção de crédito, relativamente à remessa para outro Estado e exportação para o exterior, de serviços e de mercadorias;

g) regular a forma como, mediante deliberação dos Estados e do Distrito Federal, isenções, incentivos e benefícios fiscais serão concedidos e revogados.

h) definir os combustíveis e lubrificantes sobre os quais o imposto incidirá uma única vez, qualquer que seja a sua finalidade, hipótese em que não se aplicará o disposto no inciso $\mathrm{X}, b$;

i) fixar a base de cálculo, de modo que o montante do imposto a integre, também na importação do exterior de bem, mercadoria ou serviço.

(...)"

Sacha Calmon Navarro Coêlho ${ }^{188}$ defende que "o ICM acrescentou-se dos serviços de (a) transporte e (b) comunicações em geral, ainda que municipais, antes tributados pela União, tornando-se ICM + 2 serviços = ICMS”.

O imposto, de competência estadual e distrital, pode ser instituído por meio de lei ordinária nos respectivos territórios e, via de regra, incide ${ }^{189}$ sobre a circulação de mercadorias, sobre a prestação de serviços de transporte interestadual e intermunicipal e sobre os serviços de comunicação, ainda que as operações e as prestações se iniciem no exterior.

Importante ressaltar que a Emenda Constitucional no 33/01 alterou o citado artigo 155 que passou a determinar a incidência do ICMS sobre a entrada de bem ou mercadoria importados do exterior por pessoa física ou jurídica, ainda que não seja contribuinte habitual do imposto, qualquer que seja a sua finalidade, cabendo o imposto ao Estado onde estiver situado o domicílio ou o estabelecimento do destinatário da mercadoria ou bem.

188 Curso, op. cit., p. 313.

189 Quanto às hipóteses de incidência do imposto, a doutrina não é pacífica. Roque Antonio Carrazza, por exemplo, entende que a sigla ICMS alberga pelo menos cinco impostos diferentes, com hipóteses de incidência e bases de cálculo distintas. São eles: a) o imposto sobre operações mercantis; b) o imposto sobre serviços de transporte interestadual e intermunicipal; c) o imposto sobre serviços de comunicação; d) o imposto sobre produção, importação, circulação, distribuição ou consumo de lubrificantes e combustíveis líquidos e gasosos e de energia elétrica; e, e) o imposto sobre a extração, circulação, distribuição ou consumo de minerais (ICMS, São Paulo: Malheiros, 2009, p. 36/37). Sacha Calmon Navarro Coêlho acredita que, a rigor, "o ICMS é um conglomerado de seis impostos, se computado o antigo ICM, a que se pretende dar um tratamento fiscal uniforme, a partir do princípio da nãocumulatividade, ao suposto de incidências sobre um ciclo completo de negócios (plurifasia impositiva)" (Curso, op. cit., p. 313). 
E, por determinação constitucional, é a Lei Complementar nº 87/96 (“Lei Kandir”), que define os contribuintes, a base de cálculo, o fato gerador, disciplina a nãocumulatividade do imposto, regula a forma como, mediante deliberação dos Estados e do Distrito Federal, isenções, incentivos e benefícios fiscais serão concedidos e revogados etc., enfim, determina todo o regramento do ICMS a ser observado pelos entes políticos competentes.

No Estado de São Paulo, por exemplo, o ICMS foi instituído pela Lei nº 6.374/89 e, atualmente, é regulamentada pelo Decreto no 45.490/00.

Especificamente sobre o objeto em estudo, qual seja, o uso de software (que consoante visto, se dá mediante a licença que consiste em concessão de direitos autorais, mais especificamente em autorização para o uso), é importante consignar que a LC $\mathrm{n}^{\circ}$ 87/96 não traz nenhuma disposição específica que faça da referida licença um fato subsumível à incidência do ICMS, tão pouco menciona as operações com programas de computador como hipótese de incidência do imposto estadual.

Tal qual a LC $n^{\circ}$ 87/96, a Lei paulista $n^{\circ}$ 6.374/89 não impõe a incidência do ICMS sobre a concessão de licença de uso de software ou sobre as operações com programas de computador.

Contudo, o Decreto paulista $n^{\circ} 51.619 / 07$ prevê que na operação realizada com programa para computador (software), personalizado ou não ${ }^{190}$, o ICMS será calculado sobre uma base de cálculo que corresponderá ao dobro do valor de mercado do seu suporte informático.

O Estado do Mato Grosso, por sua vez, alterou a sua legislação fiscal (Lei $n^{\circ}$ 7.098/98) para incluir a incidência do ICMS sobre operações com programa de computador, ainda que realizadas por transferência eletrônica de dados. ${ }^{191}$

190 Acreditamos que a personalização de determinado programa de computador abre espaço para o conflito de competência entre Estado e Município, na medida em que a personalização de um software (obra intelectual) se aproxima de uma prestação de serviço.

191 A inconstitucionalidade do intento estadual está sub judice nos autos da ADI no $1.945-7$, que será abordada mais adiante. Além das questões que nos levam a pensar que a concessão do direito de uso do software (bem móvel, incorpóreo, de cunho intelectual) não é passível de ser posta no comércio, vale lembrar que inexiste previsão constitucional e legal para a incidência do ICMS sobre o comércio 
Valendo-nos das definições contidas na classificação tripartite referendada pelo STF quando do julgamento do RE $n^{\circ}$ 176.626-3, que admitiu existirem três categorias de programas ("de prateleira", "sob encomenda" e "híbrido"), analisaremos a incidência do ICMS sobre operações com o programa padrão ("de prateleira"), produzido em larga escala e que é posto à disposição dos interessados em grandes lojas de departamento e supermercados, pois tal modalidade enseja dúvidas sobre a configuração ou não da hipótese de incidência do imposto estadual.

As demais "espécies" de programas serão analisadas no capítulo seguinte sobre o ISSQN por apresentarem pontos de contato com determinados serviços expressamente constantes da lista anexa à LC no 116/03.

Sendo assim, analisaremos a questão da tributação do uso do software "de prateleira" sob a ótica do ICMS-mercantil (incidente sobre as operações relativas à circulação de mercadorias), pois o fato de não haver previsão legal específica para a exigência do gravame estadual sobre transação que envolva a concessão de licença de uso não tem impedido os Estados de exigirem o imposto correspondente.

\subsection{Regime jurídico-tributário e regra-matriz de incidência tributária do ICMS (operação mercantil)}

Consoante ensina Hugo de Brito Machado ${ }^{192}$, o tributo pode ter como fato gerador uma atuação estatal específica relativa ao contribuinte ou uma situação independente de qualquer atividade estatal específica. Por isso, segundo o referido doutrinador, a doutrina brasileira classifica os tributos em vinculados (taxa e contribuição de melhoria) e não vinculados (impostos) ${ }^{193}$.

O ICMS é imposto cuja obrigação tem como fato gerador uma situação independente de qualquer atividade estatal específica, relativa ao contribuinte, conforme prevê o art. 16, do CTN.

eletrônico direto (aquele em que a entrega do bem é feita por meios digitais, sem a figura da sua saída física).

192 Curso de Direito Tributário, São Paulo: Malheiros, 2008, p. 296.

193 A despeito de o art. $5^{\circ}$ do CTN somente mencionar impostos, taxas e contribuições de melhoria como espécies tributárias, é manso e pacífico que as contribuições sociais e os empréstimos compulsórios também são tributos, tal qual restou decidido pelo STF ( $\operatorname{RE~n}^{\circ}$ 138.284-CE). 
O imposto é de competência estadual e distrital e pode ser instituído mediante lei ordinária, observando-se o disposto na Lei Complementar $n^{\circ} 87 / 96$, consoante determina o art. 155, II, $\S 2^{\circ}$, XII, da Constituição Federal.

A sua finalidade é arrecadatória, tipicamente fiscal (sem qualquer serventia parafiscal). O imposto incide ${ }^{194}$ sobre (i) operações relativas à circulação de mercadorias e (ii) sobre prestações de serviços de transporte interestadual e intermunicipal e (iii) sobre prestação de serviço de comunicação. Para o fim a que se destina o presente estudo, ateremo-nos à hipótese (i).

O ICMS é não-cumulativo, compensando-se o que for devido em cada operação relativa à circulação de mercadorias ou prestação de serviços com o montante cobrado nas anteriores pelo mesmo ou outro Estado ou pelo Distrito Federal.

Contribuinte é qualquer pessoa, física ou jurídica, que realize, com habitualidade ${ }^{195}$ ou em volume que caracterize intuito comercial, operações de circulação de mercadoria (ou prestações de serviços de transporte interestadual e intermunicipal e de comunicação, ainda que as operações e as prestações se iniciem no exterior).

É também contribuinte a pessoa física ou jurídica que, mesmo sem habitualidade ou intuito comercial importe mercadorias ou bens do exterior, qualquer que seja a sua

${ }^{194}$ Nos termos do art. $2^{\text {o }}$, da LC n (87/96, o ICMS incide sobre: a) operações relativas à circulação de mercadorias, inclusive o fornecimento de alimentação e bebidas em bares, restaurantes e estabelecimentos similares; b) prestações de serviços de transporte interestadual e intermunicipal, por qualquer via, de pessoas, bens, mercadorias ou valores; c) prestações onerosas de serviços de comunicação, por qualquer meio, inclusive a geração, a emissão, a recepção, a transmissão, a retransmissão, a repetição e a ampliação de comunicação de qualquer natureza; d) o fornecimento de mercadorias com prestação de serviços não compreendidos na competência tributária dos Municípios; e) o fornecimento de mercadorias com prestação de serviços sujeitos ao imposto sobre serviços, de competência dos Municípios, quando a lei complementar aplicável expressamente o sujeitar à incidência do imposto estadual; f) a entrada de mercadoria ou bem importados do exterior, por pessoa física ou jurídica, ainda que não seja contribuinte habitual do imposto, qualquer que seja a sua finalidade; g) o serviço prestado no exterior ou cuja prestação se tenha iniciado no exterior; h) a entrada, no território do Estado destinatário, de petróleo, inclusive lubrificantes e combustíveis líquidos e gasosos dele derivados, e de energia elétrica, quando não destinados à comercialização ou à industrialização, decorrentes de operações interestaduais, cabendo o imposto ao Estado onde estiver localizado o adquirente.

195 Sobre este aspecto, Roque Antonio Carrazza esclarece que: "Pensamos, portanto, não ser excessivamente arrojada a ideia de que pode ser contribuinte do ICMS qualquer pessoa (física, jurídica ou, até, sem personificação de Direito) envolvida, em caráter de habitualidade, com a prática de operações mercantis. É o que, aliás, expressamente estipulam o art. $4^{\circ}$ da Lei Complementar no 87/1996 (Lei Kandir) e o art. $7^{\circ}$ da Lei paulista ${ }^{\circ}$ 6.374/1989. Carlos da Rocha Guimarães é de idêntico pensar: Assim, a habitualidade é o critério que nos guia no diferenciar o intuito objetivo do subjetivo, e que transforma a simples circulação jurídica de bens em circulação de mercadorias.” (ICMS, São Paulo: Malheiros, 2009, p. 40.). 
finalidade; seja destinatária de serviço prestado no exterior ou cuja prestação se tenha iniciado no exterior; adquira em licitação mercadorias ou bens apreendidos ou abandonados; adquira lubrificantes e combustíveis líquidos e gasosos derivados de petróleo e energia elétrica oriundos de outro Estado, quando não destinados à comercialização ou à industrialização.

Por iniciativa do Presidente da República ou de um terço dos Senadores, caberá ao Senado Federal, por meio de resolução, estabelecer as alíquotas aplicáveis às operações e prestações, interestaduais e de exportação.

Nesse sentido, a Resolução do Senado $n^{\circ}$ 22/89 estabelece que a alíquota do imposto nas operações e prestações interestaduais será de $12 \%$ e que nas operações e prestações realizadas nas Regiões Sul e Sudeste destinadas às Regiões Norte, Nordeste e Centro-Oeste e ao Estado do Espírito Santo, a alíquota será de 7\%. ${ }^{196}$

É facultado ao Senado Federal estabelecer alíquotas mínimas nas operações internas, mediante resolução de iniciativa de um terço e aprovada pela maioria absoluta de seus membros, bem como fixar alíquotas máximas nas mesmas operações para resolver conflito específico que envolva interesses de Estados, mediante resolução de iniciativa da maioria absoluta e aprovada por dois terços de seus membros.

Em relação às operações e prestações que destinem bens e serviços a consumidor final localizado em outro Estado, será adotada a alíquota interestadual quando o destinatário for contribuinte do imposto ${ }^{197}$ e a alíquota interna quando o destinatário não for contribuinte dele.

\footnotetext{
${ }^{196}$ A Resolução do Senado no 95/96 estabelece a alíquota de 4\% quando da prestação de transporte aéreo interestadual de passageiro, carga e mala postal, contudo, ao julgar a ADIN n ${ }^{\circ} 1.600$, o STF reconheceu a não incidência do ICMS sobre a prestação de serviços de transporte aéreo, de passageiros (intermunicipal, interestadual e internacional), bem como a inconstitucionalidade da exigência do imposto na prestação de serviços de transporte aéreo internacional de cargas pelas empresas aéreas nacionais, enquanto persistirem os convênios de isenção de empresas estrangeiras. A Resolução do Senado no $13 / 12$, com efeitos a partir de $1^{\circ}$ de janeiro de 2013, estabelece a alíquota de $4 \%$ nas operações interestaduais com bens e mercadorias importadas do exterior (vide Ajustes SINIEF n ${ }^{\circ}$ 19/2012 e 20/2012).

${ }^{197}$ Caberá ao Estado de destino o imposto correspondente à diferença entre a alíquota interna e a interestadual.
} 
De forma geral, no Estado de São Paulo as alíquotas aplicadas são as previstas no art. 52, do RICMS (Decreto $n^{\circ}$ 45.490/00), nos seguintes termos: 18\% nas operações ou prestações internas, ainda que iniciadas no exterior; $7 \%$ nas operações ou prestações interestaduais que destinarem mercadorias ou serviços a contribuintes localizados nos Estados das regiões Norte, Nordeste e Centro-Oeste e no Estado do Espírito Santo; 12\% nas operações ou prestações interestaduais que destinarem mercadorias ou serviços a contribuintes localizados nos Estados das regiões Sul e Sudeste; 4\% nas prestações interestaduais de transporte de carga e mala postal, em que o destinatário do serviço seja contribuinte do imposto; e, $12 \%$ ou $25 \%$ nas operações com energia elétrica.

O ICMS pode ser seletivo em razão da essencialidade das mercadorias e dos serviços, de modo que o Estado pode levar em conta a essencialidade do produto e adotar uma alíquota menor para os essenciais e outra maior para os supérfluos.

O gravame estadual não incide ${ }^{198}$ sobre operações que destinem produtos (e serviços) ao exterior, sendo assegurada a manutenção e o aproveitamento do crédito do imposto cobrado nas prestações anteriores.

Consoante ensina Paulo de Barros Carvalho ${ }^{199}$, a regra-matriz de incidência tributária ou norma tributária em sentido estrito é a que prescreve a incidência tributária e é composta do antecedente (descritor: diretrizes para identificação de eventos portadores de expressão econômica aliados ao comportamento de uma pessoa e à definição de tempo e espaço) e de um consequente (prescritor: critérios pessoal e quantitativo - base de cálculo e alíquota).

A regra-matriz de incidência tributária é uma norma geral e abstrata ${ }^{200}$ que atinge as condutas intersubjetivas por intermédio do ato jurídico-administrativo de lançamento ou de ato do particular, veículos que introduzem uma norma individual e concreta no sistema. ${ }^{201}$

${ }^{198}$ Nos termos do art. 155, II, $\S 2^{\circ}$, X, da Constituição Federal, o imposto também não incide sobre operações que destinem a outros Estados petróleo, lubrificantes, combustíveis líquidos e gasosos dele derivados e sobre energia elétrica; sobre o ouro em determinadas hipóteses; e, sobre as prestações de serviço de comunicação nas modalidades de radiodifusão sonora e de sons e imagens de recepção livre e gratuita.

199 Direito Tributário - Fundamentos Jurídicos da Incidência, São Paulo: Saraiva, 1998, p. 80.

${ }^{200}$ De acordo com a teoria desenvolvida por Paulo de Barros Carvalho, "as normas gerais e abstratas reivindicam, para a regulação efetiva dos comportamentos interpessoais, a expedição de normas individuais e concretas. E no campo do direito tributário não poderia ser diferente. Sendo a regra-matriz 
Segundo o referido doutrinador, "a conjunção dos dados constantes da hipótese e do consequente permite exibir o núcleo-estrutural da norma-padrão, preenchido com os requisitos significativos necessários e suficientes para o impacto jurídico da exação"202, o que equivale à operação lógica de inclusão de um elemento numa classe, ou seja, à subsunção do conceito do fato ao conceito da norma ${ }^{203}$. Contudo, a subsunção do fato à classe de acontecimentos descritos no antecedente somente se perfaz com a expedição da competente norma individual e concreta, pois esta sim fará irradiar a obrigação tributária $^{204}$.

Partindo da teoria difundida por Paulo de Barros Carvalho, tem-se que sem a subsunção do fato ocorrido no mundo fenomênico à classe dos fatos descritos na hipótese não há relação de causalidade entre a hipótese e o efeito previsto no consequente da regramatriz de incidência tributária, o que inviabiliza a expedição de norma individual e concreta e, consequentemente, as repercussões fiscais.

Resta saber se a concessão de licença de uso de software "de prateleira" se subsume ao previsto na regra-matriz de incidência tributária do ICMS sobre operações relativas à circulação de mercadorias, assim exposta: Hipótese $^{205}$ : a) critério material - realizar operações relativas à circulação de mercadorias; b) critério espacial - qualquer lugar do território do Estado ou do Distrito Federal que tenha editado a lei instituidora do imposto; c) critério temporal - via de regra, no momento da saída das mercadorias do estabelecimento comercial, industrial ou produtor; Consequente ${ }^{206}$ : d) critério pessoal -

uma norma geral e abstrata, obviamente está por requerer norma individual e concreta para chegar às condutas e discipliná-las positivamente" (Direito Tributário - Fundamentos Jurídicos da Incidência, São Paulo: Saraiva, p. 83)

201 CARVALHO, Paulo de Barros, Direito Tributário - Fundamentos Jurídicos da Incidência, São Paulo: Saraiva, 1998, p. 35.

202 CARVALHO, Paulo de Barros, Direito, op. cit., p. 81.

203 CARVALHO, Paulo de Barros, Direito, op. cit., p. 82.

204 CARVALHO, Paulo de Barros, Direito, op. cit., p. 83.

205 De acordo com a teoria de Paulo de Barros Carvalho, a hipótese pode ser assim explicada: "Há de significar, sempre, a descrição normativa de um evento que, concretizado no nível das realidades materiais e relatado no antecedente de norma individual e concreta, fará irromper o vínculo abstrato que o legislador estipulou na consequência. Trata-se de peça de juízo hipotético que estipula a regulação de conduta, prescrevendo direitos e obrigações para as pessoas físicas ou jurídicas envolvidas, de alguma forma, no acontecimento do fato jurídico tributário" (Curso de Direito Tributário, São Paulo: Saraiva, 2004, p. 244-280).

206 De acordo com a teoria de Paulo de Barros Carvalho, o consequente pode ser assim explicado: "Como prescritor, nos dá, também, critérios para a identificação do vínculo jurídico que nasce, facultando-nos saber quem é o sujeito portador do direito subjetivo; a quem foi cometido o dever jurídico de cumprir certa prestação; e seu objeto, vale dizer, o comportamento que a ordem jurídica espera do sujeito passivo 
sujeito ativo é o Estado ou o Distrito Federal e sujeito passivo é a pessoa física ou jurídica que dá ensejo às operações de circulação de mercadorias; e) critério quantitativo - base de cálculo é o valor da operação e a alíquota é um percentual sobre a base de cálculo nos termos definidos pela lei.

\subsection{Conceito de operações relativas à circulação de mercadorias}

Considerando que o critério material da regra-matriz de incidência do ICMSmercantil são operações relativas à circulação de mercadorias (também conhecidas por compra e venda), a fim de verificar se há ou não identidade destas com a concessão de licença de uso de software "de prateleira", não se pode deixar de verificar em que consistem as referidas operações.

A partir das lições de José Souto Maior Borges ${ }^{207}$, tem-se que o ICMS não incide sobre "circulação" nem sobre "mercadorias", mas, sobre "operações", de modo que o ponto central da materialidade do imposto é o vocábulo "operações”.

Em artigo redigido na década de 70 , Geraldo Ataliba ${ }^{208}$ discorreu a respeito da hipótese de incidência do ICM e fez ponderações no mesmo sentido, aplicáveis ao ICMS, que denotam que as "operações" é que são realizadas por produtores, industriais, e comerciantes e não a circulação, de modo que não se pode cogitar que o constituinte teria cometido erro de concordância ao redigir o dispositivo de modo a prever recair o tributo sobre "circulação" realizada.

Assim, o vocábulo "operações" deve ser entendido como atos juridicamente relevantes, bilaterais, regulados pelo direito mercantil, que se repetem sucessivamente, de modo que o ICMS incide sobre atos jurídicos que impulsionam a circulação de mercadorias. $^{209}$

e que satisfaz, a um só tempo, o dever que lhe fora atribuído e o direito subjetivo de que era titular o sujeito pretensor" (Curso de Direito Tributário, São Paulo: Saraiva, 2004, p. 244-280).

207 O Fato Gerador do I.C.M. e os Estabelecimentos Autônomos, Revista de Direito Administrativo, vol. 103, FGV-Instituto de Documentação: Rio de Janeiro, 1971, p. 35.

208 ICM sobre a importação de bens de capital para uso do importador, Revista Forense, no 250, 1975, p. 115.

209 Cf. BORGES, José Souto Maior, ICM sobre a importação de bens de capital para uso do importador, Revista Forense, no 250, 1975, p. 122. 
Portanto, as operações às quais se referem a Constituição e a LC n ${ }^{\circ}$ 87/96 equivalem a atos jurídicos praticados por aqueles que realizam transações mercantis relativas à circulação de mercadorias tais como, os atos dos produtores, industriais ou comerciantes. $^{210}$

A não-cumulatividade a que está sujeito o imposto contribui para a constatação de que as operações tributadas são aquelas marcadas pela sucessão de transações mercantis, ou seja, pela ocorrência de atos sucessivos. Esses atos sucessivos elucidam que as operações são dotadas de dinamicidade.

Contudo, não há que se falar em "operações relativas à circulação de mercadorias" sem que as mercadorias sejam transferidas de um titular a outro e neste ponto consiste a configuração da "circulação de mercadorias", pois as transações mercantis de trato sucessivo requerem alternância do titular. ${ }^{211}$

E, por assim dizer, considerando que o art. 155, II, da Constituição Federal prevê que apenas as operações relativas à circulação de mercadorias (fatos jurídicos ${ }^{212}$ ) serão tributadas pelo ICMS, pode-se dizer que a "circulação" está a qualificar as “operações".

Nesse sentido, posiciona-se Sacha Calmon Navarro Coêlho ${ }^{213}$ para quem a palavra operação garante que a circulação de mercadoria é a adjetivação e que somente terá relevância jurídica a operação mercantil que acarrete a circulação da mercadoria como meio de se transferir a sua titularidade.

Para o Professor Alcides Jorge Costa, circulação é uma série de operações que levam as mercadorias da fonte de produção até o consumo final, de acordo com a sua

${ }^{210}$ Cf. TÔRRES, Heleno Taveira, A Hipótese do ICMS sobre Operações Mercantis na Constituição e a Solução dos Conflitos Normativos, in Schoueri, Luís Eduardo (coord.), Direito Tributário - Homenagem a Paulo de Barros Carvalho, São Paulo: Quartier Latin, 2008, p. 327.

${ }^{211}$ Cf. TÔRRES, Heleno Taveira, A Hipótese, op. cit., p. 332.

${ }^{212}$ Consoante elucida o Professor Alcides Jorge Costa: "a operação relativa à circulação de mercadorias é um ato jurídico porque dela sempre decorrem as consequências previstas em lei mas, ainda para efeitos tributários, é sempre um fato jurídico 'stricto sensu' porque suas consequências no campo fiscal independem da vontade das partes" (ICM, op. cit., p. 91).

${ }^{213}$ Venda de refeições a empresas que as fornecem a seus empregados no bojo do programa de alimentação do trabalhador (PAT) - Inexistência de operação de saída de mercadoria - Desnecessidade de recolhimento do ICMS-ST pelo fabricante, Revista Dialética de Direito Tributário, $\mathrm{n}^{\circ}$ 129, São Paulo: Dialética, 2006, p. 124. 
natureza e finalidades, agregando-lhes valor em cada etapa deste percurso, podendo ou não ocasionar a transferência de posse ou de propriedade da mercadoria:

\begin{abstract}
"Em suma, circulação é o encaminhamento da mercadoria em direção ao consumo, inclusive o chamado auto-consumo; este encaminhamento faz-se através de operações que tanto podem ocasionar transferência de propriedade ou de posse da mercadoria, como não. Neste encaminhamento, é relevante qualquer operação de que resulte acréscimo de valor da mercadoria." 214
\end{abstract}

Em parecer sobre a não incidência do ICMS sobre a transferência de bem do ativo fixo para outro estabelecimento da empresa, o mestre é categórico: "só há operação relativa à circulação de mercadorias quando ocorre a transferência de propriedade destas."215

Roque Antonio Carrazza ${ }^{216}$ assevera que a circulação a que se refere a Constituição e as demais normas só pode ser jurídica e não meramente física e que a primeira pressupõe a transferência (de uma pessoa para outra) da posse ou da propriedade da mercadoria, de modo que sem a mudança da sua titularidade, não há que se falar em tributação por meio do ICMS.

Portanto, a simples circulação física de mercadorias (mero deslocamento físico) não dá ensejo ao dever de pagar o ICMS. Somente a circulação jurídica da mercadoria, assim entendida como a que proporciona a transferência da titularidade em favor de outrem, mediante o recebimento de uma contraprestação, é capaz de fazer nascer a obrigação de pagar o imposto estadual.

Consoante alerta Aliomar Baleeiro ${ }^{217}$, sustentar o contrário equivale a dizer que a saída em decorrência do furto ou do roubo configura hipótese de incidência tributária, o que não é verdade.

Assim, as operações relativas à circulação (jurídica) de mercadoria, critério material da regra-matriz de incidência do ICMS mercantil, pressupõem sucessivas

\footnotetext{
214 ICM, op. cit., p. 86/88.

${ }^{215}$ ICMS - Importação - Máquina para uso em processo produtivo - Transferência para outro estabelecimento da empresa - Significado da expressão "Bem do Ativo Fixo", Revista de Estudos Tributários, vol. 15, Síntese: São Paulo, 2000, p. 144.

216 ICMS, São Paulo: Malheiros, 2009, p. 38.

${ }^{217}$ ICM sobre a importação de bens de capital para uso do importador, Revista Forense, $\mathrm{n}^{\circ}$ 250, Rio de Janeiro, 1975, p.139.
} 
transações mercantis acompanhadas de transferências da titularidade da mercadoria com vistas a permitir que esta siga do fabricante até o consumidor final.

É justamente por isso que a circulação de mercadorias entre estabelecimentos de um mesmo contribuinte constitui mera circulação física de bens, pois a transferência da titularidade destas simplesmente não acontece.

A tal título, elucidativas são as palavras de Arnoldo Wald: "não se deve confundir nem identificar a circulação econômica com a saída física, o transporte dentro da mesma empresa mediante a remessa de armazém a filial ou de um para outro estabelecimento da firma, como a transferência de bens para terceiros, pois somente ocorre a circulação quando a mercadoria é transferida, passando de um patrimônio para outro, qualquer que seja a motivação jurídica."218

Tal entendimento já foi referendado pelos Tribunais Superiores, pois de acordo com os entendimentos do STF e do STJ firmados, respectivamente, quando do julgamento do Agravo de Instrumento no 131.941-1-SP e do Recurso Especial no 32.203-RJ. Este último, inclusive, deu ensejo à edição da Súmula $\mathrm{n}^{\circ} 166 / \mathrm{STJ}^{219}$, segundo a qual não constitui fato gerador do ICMS o simples deslocamento de mercadorias de um para outro estabelecimento do mesmo contribuinte ${ }^{220}$.

Ressalte-se que o princípio da autonomia dos estabelecimentos, previsto no art. $6^{\circ}$, do Decreto-Lei $n^{\circ} 406 / 68^{221}$ e no art. $11, \S 3^{\circ}$, II, da Lei Complementar $n^{\circ} 87 / 96^{222}$, não é

${ }^{218}$ Base de cálculo para a cobrança do ICM, nas transferências de armazéns para filiais da mesma empresa, Revista de Direito Público, vol. 19, p. 236.

$219<$ http://www.stj.jus.br/docs_internet/SumulasSTJ.pdf>. Acesso em: 06 dez. 2012.

${ }^{220}$ Nos termos do art. $13, \S 4^{\circ}$, da LC n ${ }^{\circ} 87 / 96$, em caso de operação interestadual entre estabelecimentos do mesmo contribuinte, admite-se a incidência do imposto. Vide também o RESP nº 1.109.298/RS.

221 "Art $6^{\circ}$ - Contribuinte do impôsto é o comerciante, industrial ou produtor que promove a saída da mercadoria, o que a importa do exterior ou o que arremata em leilão ou adquire, em concorrência promovida pelo Poder Público, mercadoria importada e aprendida.

(...)

$\S 2^{\circ}$ Os Estados poderão considerar como contribuinte autônomo cada estabelecimento comercial, industrial ou produtor, permanente ou temporário do contribuinte, inclusive veículos utilizados por êste no comércio ambulante."

222 “Art. 11. O local da operação ou da prestação, para os efeitos da cobrança do imposto e definição do estabelecimento responsável, é:

(...)

$\S 3^{\circ}$ Para efeito desta Lei Complementar, estabelecimento é o local, privado ou público, edificado ou não, próprio ou de terceiro, onde pessoas físicas ou jurídicas exerçam suas atividades em caráter temporário ou permanente, bem como onde se encontrem armazenadas mercadorias, observado, ainda, o seguinte: 
válido para a configuração da hipótese de incidência do ICMS em operações interestabelecimentos, muito embora seja válido para outros fins.

Mais recentemente, em 2007, ao afastar a incidência do ICMS sobre as operações de leasing (arrendamento mercantil) de aeronaves, o STF confirmou a posição adotada quanto à imprescindibilidade da transferência de titularidade do bem ${ }^{223}$ para restar configurada a "operação relativa à circulação de mercadoria".

\subsection{Conceito de mercadorias}

Conforme já asseverado, a Constituição apenas autoriza a tributação de atos de "circulação" de bens qualificados como "mercadorias", quando promovidas mediante "operações" juridicamente relevantes e que permitam sua verificação no tempo e no espaço. $^{224}$

Da mesma forma que o vocábulo "circulação" qualifica "operações", "mercadorias" é adjetivo de qualificação da operação tributada que serve para demarcar os limites da incidência do ICMS. ${ }^{225}$ Sendo assim, Roque Antonio Carrazza pontua que:

\footnotetext{
"Salientamos que a Constituição não prevê a tributação de mercadorias por meio do ICMS, mas, sim, a tributação das 'operações que têm mercadorias', isto é, das operações que têm mercadorias por objeto. Os termos 'circulação' e 'mercadorias' qualificam as operações tributadas por via de ICMS. Não são todas as operações jurídicas que podem ser tributadas, mas apenas as relativas à circulação de mercadorias. O ICMS só pode incidir sobre operações que
}

(...)

II - é autônomo cada estabelecimento do mesmo titular;

(...)"

223 "RECURSO EXTRAORDINÁRIO. ICMS. NÃO-INCIDÊNCIA. ENTRADA DE MERCADORIA IMPORTADA DO EXTERIOR. ART. 155, II DA CB. LEASING DE AERONAVES E/OU PEÇAS OU EQUIPAMENTOS DE AERONAVES. OPERAÇÃO DE ARRENDAMENTO MERCANTIL. 1. A importação de aeronaves e/ou peças ou equipamentos que as componham em regime de leasing não admite posterior transferência ao domínio do arrendatário. 2. A circulação de mercadoria é pressuposto de incidência do ICMS. O imposto --- diz o artigo 155, II da Constituição do Brasil --- é sobre 'operações relativas à circulação de mercadorias e sobre prestações de serviços de transporte interestadual e intermunicipal e de comunicação, ainda que as operações e as prestações se iniciem no exterior'. 3. Não há operação relativa à circulação de mercadoria sujeita à incidência do ICMS em operação de arrendamento mercantil contratado pela indústria aeronáutica de grande porte para viabilizar o uso, pelas companhias de navegação aérea, de aeronaves por ela construídas. 4. Recurso Extraordinário do Estado de São Paulo a que se nega provimento e Recurso Extraordinário de TAM - Linhas Aéreas S/A que se julga prejudicado." (STF, RE n⿳ 461.968-7, Ministro Relator Eros Grau, DJ 30.05.2007)

224 Cf. TÔRRES, Heleno Taveira, A Hipótese, op. cit., p. 327.

225 Cf. TÔRRES, Heleno Taveira, A Hipótese, op. cit., p. 326. 
conduzem mercadorias, mediante sucessivos contratos mercantis, dos produtores originários aos consumidores finais." 226

Em que pese a Constituição Federal não defina expressamente em que consistem "mercadorias" 227 , é possível construir uma definição a partir da estreita repartição de competências tributárias (que obsta, ao menos em tese, que os entes federados tributem os mesmos fatos imponíveis). Em outras palavras, a repartição de competências tributárias é o vetor que nos guia e indica que existe uma definição ainda que implícita.

Heleno Taveira Tôrres ${ }^{228}$ defende que o sentido a ser atribuído ao termo juridicamente qualificado como "mercadorias" pela Constituição, deve ser aquele que a legislação de direito privado designa como tal nas diversas hipóteses de mercantilidade juridicamente admitidas, em respeito ao art. 110, do CTN.

Afinal, a lei tributária não está autorizada a alterar a definição, o conteúdo e o alcance de institutos, conceitos e formas de direito privado quando estes forem tipos constitucionalmente previstos para a repartição de competências tributárias, pois, do contrário, restaria prejudicada a hierarquia normativa e os princípios que garantem a segurança jurídica no ordenamento. ${ }^{229}$

Neste aspecto, não se pode deixar de mencionar a célebre passagem do voto do então Ministro Luiz Gallotti, do Supremo Tribunal Federal, que ao julgar o RE nº 71.758 sobre o imposto de renda, imortalizou a máxima: se a lei pudesse chamar de compra o que não é compra, de importação o que não é importação, de exportação o que não é exportação, de renda o que não é renda, ruiria todo o sistema tributário inscrito na Constituição.

Sob a égide da Constituição anterior, o STF decidiu que não constituíam fatos subsumíveis ao então ICM os que, a despeito de terem por objeto bens materiais, não

\footnotetext{
${ }^{226}$ ICMS, São Paulo: Malheiros, 2009, p. 38/39.

227 Ao julgar o RE n 176.626-3, o então Ministro Sepúlveda Pertence asseverou: "a controvérsia, a meu ver, é insolúvel sem a precisão do conceito de 'mercadoria', contido no art. 155, II, da CF, e essencial à demarcação do âmbito constitucional de incidência possível do ICMS, incluído por aquele dispositivo na competência do Estado."

${ }^{228}$ A Hipótese, op. cit., p. 333.

229 Cf. TÔRRES, Heleno Taveira, A Hipótese, op. cit., p. 333.
} 
fossem mercadorias. ${ }^{230}$ As reiteradas decisões no mesmo sentido deram ensejo à Súmula $\mathrm{n}^{\mathrm{o}}$ $570^{231}$, segundo a qual o imposto de circulação de mercadorias não incide sobre importação de bens de capital. $^{232}$

Em artigo sobre a celeuma da época, no tocante à incidência ou não do ICM sobre a importação de bens de capital, Aliomar Baleeiro ${ }^{233}$ ressaltou que mercadoria é uma espécie do gênero "produto" ou de "bens" que alguém com o propósito deliberado de lucro produz para vender ou compra para revender, bem como toda circulação de mercadoria representa circulação de bem material, mas que o inverso não é verdadeiro: nem todo bem material circulado é mercadoria.

Portanto, quando não se tratar de mercadoria, não haverá a incidência do ICMS, pois a Constituição Federal não admite a incidência do gravame sobre qualquer bem, há de ser mercadoria. Não obstante isso, árdua é a tarefa de definir o vocábulo "mercadoria".

Há quem ${ }^{234}$ diga que mercadoria é o bem destinado ao comércio. Outros ${ }^{235}$ defendem que mercadoria é bem destinado ao comércio desde que seja móvel (os imóveis estariam excluídos da definição). Há, ainda, aqueles ${ }^{236}$ que apontam como critério definidor a materialidade/corporalidade do bem atrelada à destinação a lhe ser dada: mercancia.

${ }^{230}$ Cf. BARRETO, Aires F., ICMS e ISS - Estremação da Incidência, Revista Dialética de Direito Tributário, nº 71, São Paulo: Dialética, 2001 p. 10.

231 <http://www.stf.jus.br/arquivo/cms/jurisprudenciaSumula/anexo/Sumula_do_STF__1_a_736.pdf.>. Acesso em: 06 dez. 2012.

${ }^{232}$ Muito embora a $\mathrm{EC} \mathrm{n}^{\circ} 23 / 83$ tenha constitucionalizado a incidência do ICM sobre a importação de bens destinados ao ativo fixo, fato é que o entendimento do STF, até então, pautava-se pela não incidência do imposto sobre a importação de bens que não se destinassem à revenda (ou seja, que não configurassem mercadoria).

${ }^{233}$ ICM sobre a importação de bens de capital para uso do importador, Revista Forense, no 250, Rio de Janeiro, 1975, p. 143/149.

${ }^{234}$ BORGES, José Souto Maior, ICM sobre a importação de bens de capital para uso do importador, Rio de Janeiro: Revista Forense, nº 250, 1975, p. 125. OLIVEIRA, Ricardo Mariz de, Operações relacionadas com imóveis e empresas construtoras, Revista Dialética de Direito Tributário, n 6 , São Paulo: Dialética, 1996, p. 75. CARVALHO, Paulo de Barros, Regra matriz do ICM, Tese de livre-docência em direito tributário apresentada à Faculdade de Direito da Pontifícia Universidade Católica de São Paulo, 1981, p. 206.

${ }^{235}$ MACHADO, Hugo de Brito, Aspectos fundamentais do ICMS, São Paulo: Dialética, 1997, p. 22. LIMA, Sebastião de Oliveira, $O$ fato gerador do imposto de importação no direito brasileiro, São Paulo: Resenha Tributária, 1981, p. 45/46.

${ }^{236}$ COSTA, Alcides Jorge Costa, ICM, op. cit., p. 99. 
Marco Aurélio Greco ${ }^{237}$ admite a existência de três definições para o termo "mercadoria". Segundo ele, a primeira é determinada pela natureza do objeto, ou seja, em razão da materialidade do bem, de modo que somente o bem corpóreo é mercadoria. A segunda definição guarda relação com a qualificação subjetiva daquele que pratica a operação de circulação de mercadoria, o qual deve ser comerciante e objetivar, portanto, a venda/revenda do bem adquirido. A terceira e última definição decorre de um critério econômico, segundo o qual mercadoria é o bem enquanto objeto de determinado mercado.

Guilherme Cezaroti ${ }^{238}$ informa que o termo "mercadoria" tem origem no latim "mercatura", que é aquilo que se comprou para ser colocado à venda. Para ele o conceito de mercadoria está ligado à ideia de bens materiais que o comerciante revende para os seus consumidores em geral; é aquilo que está à disposição no mercado, assim entendido como o local onde os consumidores podem adquirir gêneros de que necessitam.

A definição de mercadoria como bem destinado ao comércio é a mais tradicional e sempre esteve relacionada com o art. 191, do Código Comercial (parcialmente revogado pelo Código Civil de 2002), dado que a referida destinação faz da operação uma circulação mercantil, tutelada pelo direito comercial.

A tal título, cite-se a decisão proferida pela $2^{\mathrm{a}}$ Turma do STF, em 09.04.1991, nos autos do Agravo de Instrumento n ${ }^{\circ}$ 131.941-1, sob a relatoria do Ministro Marco Aurélio, segundo a qual, a própria designação do imposto, no que consagra o emprego do vocábulo “mercadoria”, pressupõe o ato mercantil, encontrando-se a definição do termo no Direito Comercial. $^{239}$

Em artigo sobre bens de capital, Geraldo Ataliba ${ }^{240}$ foi enfático ao defender que não é qualquer coisa que circula que se compreende no conceito constitucional do imposto

\footnotetext{
237 Internet e Direito, São Paulo: Dialética, 2000, p. 82/83.

${ }^{238}$ A incidência, op. cit., p. 49.

${ }^{239}$ Na mesma decisão, o Ministro asseverou: "Em síntese, consubstancia mercadoria coisa móvel destinada à comercialização, que geralmente é adquirida por pessoas do comércio para a revenda, muito embora haja a incidência do imposto quando se trate de mercadoria importada do exterior pelo titular, ainda que destinada ao consumo ou ativo fixo do estabelecimento - $\S 1^{\circ}$ do artigo 23 da Constituição Federal anterior. Frise-se, por oportuno, que o Decreto-lei $n^{\circ} 406 / 68$ equipara a saída de mercadoria à transferência da propriedade, mesmo que não tenha entrado no estabelecimento do transmitente, o que revela ser a transmissão da propriedade pressuposto da incidência."

240 ICM sobre a importação de bens de capital para uso do importador, Revista Forense, $\mathrm{n}^{\circ}$ 250, Rio de Janeiro, 1975, p. 115.
} 
estadual, mas só mercadorias que, tradicionalmente, são objeto de uma atividade que juridicamente se qualifica como mercancia, regulada pelo direito comercial.

No mesmo sentido, Paulo de Barros Carvalho ${ }^{241}$ defende que a circulação deve ser impulsionada por operações jurídicas de qualquer jaez sempre qualificáveis como mercantis, regidas pelo direito comercial.

O referido doutrinador pondera, ainda, que a natureza mercantil do produto não está entre os requisitos que lhe são intrínsecos, mas na destinação que se lhe dê. Exemplifica dizendo que é mercadoria a caneta exposta à venda entre outras adquiridas para esse fim e que não o será aquela mantida em seu bolso para uso pessoal, já que apenas a destinação confere-lhe atributos de mercadoria. ${ }^{242}$

E, por assim dizer, quando alguém vende um bem sem habitualidade, ou seja, sem que a comercialização seja a sua atividade econômica, não há que se falar em incidência do ICMS, pois o referido bem não é mercadoria, já que, inicialmente, não foi adquirido para tal fim. Contudo, se a mesma pessoa compra determinado bem com o intuito de revenda e assim atua com habitualidade, aí sim passará a ser contribuinte do imposto.

Parece-nos adequado e coerente sustentar que determinado bem será qualificado como mercadoria se for adquirido para ser vendido ou revendido pelo comprador $^{243}$, o que equivale a dizer que será ou não uma mercadoria em razão da destinação que se lhe dê o comprador, já que não se pode esperar que o vendedor conheça a finalidade por aquele planejada. $^{244}$

Heleno Taveira Tôrres comunga do mesmo entendimento:

${ }^{241}$ Regra-matriz do ICM. Tese de livre-docência em Direito Tributário apresentada à Faculdade de Direito da Pontifícia Universidade Católica de São Paulo, 1981, p. 170.

242 Regra-matriz, op. cit., p. 170.

${ }^{243}$ Há quem defenda o contrário. José Souto Maior Borges, por exemplo, acredita que "Para os efeitos do regime jurídico do tributo, o conceito de mercadoria tanto convém à designação da coisa móvel que o produtor comerciante ou industrial comprou e é destinada à revenda, quanto ao bem móvel que é objeto de uma operação de compra e venda para ser utilizado na produção de outras coisas móveis, que serão por sua vez destinadas a venda. (...) Para os efeitos fiscais, é indiferente portanto que a importação de bens seja destinada ou não a aplicação no ativo fixo. A caracterização da mercadoria independe da intenção do adquirente" (ICM sobre a importação de bens de capital para uso do importador, Revista Forense, $\mathrm{n}^{\circ} 250$, Rio de Janeiro, 1975, p. 125/126).

${ }^{244}$ Cf. CEZAROTI, Guilherme, A incidência, op. cit., p. 78/79. 
"Bens ou mercadorias adquiridos por uma entidade empresária podem ter como destino a mercancia, o consumo ou o ativo permanente. Quando dada destinação mercantil, então teremos 'mercadoria' e, com a operação e respectiva circulação, a oportunidade para a incidência do ICMS, com a saída da mercadoria do estabelecimento. Contudo, nada impede que ela possa preferir integrar o bem ao seu ativo ou mesmo destiná-la a consumo. Em um e outro caso, não há que se falar em incidência do ICMS.",245

É importante afastar neste momento o princípio da não contradição que, segundo Geraldo Ataliba ${ }^{246}$, consiste em não se consentir que uma coisa seja e não seja ao mesmo tempo. Em outras palavras, que o bem seja mercadoria para o vendedor mas assim não seja para o comprador, pois os critérios meramente lógicos não podem ser aplicados às questões jurídicas repletas de bilateralidades. ${ }^{247}$

Assim, quando os bens, por materiais que sejam, não configuram mercadorias, é vedado ao legislador prever a incidência do ICMS sobre a operação de circulação e, com maior razão, é vedado ao aplicador administrativo pretender exigi-lo. ${ }^{248}$

"Exceção" é feita em relação à importação de bens do exterior ainda que se destinem ao consumo ou ao ativo fixo do estabelecimento, pois desde a Emenda Constitucional n ${ }^{\circ} 23 / 83^{249}$, também conhecida como "Emenda Passos Porto", o constituinte derivado ampliou a hipótese de incidência do então ICM fazendo-o recair sobre bens que não configuravam mercadorias, admitindo a importação para consumo como critério material da regra-matriz de incidência tributária. A Constituição Federal de 1988 manteve tal hipótese, o que constitui "exceção" à regra já exposta quanto à necessidade do bem objeto da operação de circulação ser mercadoria (assim entendida como o bem destinado

245 A Hipótese, op. cit., p. 331.

${ }^{246}$ ICM sobre a importação de bens de capital para uso do importador, Revista Forense, no 250 , Rio de Janeiro, 1975, p. 117.

247 Geraldo Ataliba bem discorreu a respeito: “Assim, o que para uma parte numa relação (mutuante, p. ex.) é crédito, para a outra (mutuário) é débito. O que para uma é direito subjetivo, para outra é dever. O que para uma é obrigação, para outra é pretensão. O mundo do direito está povoado de casos que tais, evidenciando que uma coisa pode ser e não ser ao mesmo tempo, 'segundo a perspectiva do observador'. A despeito da unidade incindível de uma moeda, conforme o ponto de vista adotado para considerá-la, nela reconheceremos ou a 'cara ou a coroa'. E nenhuma das duas posições será falsa, nem infringente do princípio da não contradição. Apenas encaram, com objetividade e realismo, faces opostas do mesmo objeto, uno por natureza, mas passível de enfoque duplo. (...) Uma coisa pode ser mercadoria (espécie) para o vendedor e não ser para o comprador. (...)" (ICM sobre a importação de bens de capital para uso do importador, Revista Forense, no 250, Rio de Janeiro, 1975, p. 117/118).

${ }^{248}$ Cf. BARRETO, Aires F., ICMS e ISS, op. cit., p. 8.

249 A referida emenda ("Passos Porto") incluiu o §11 no inciso II, do art. 23, da Constituição de 1967 (EC nº 1/69), determinando a incidência do ICM sobre a entrada, em estabelecimento comercial, industrial ou produtor, de mercadoria importada do exterior por seu titular, inclusive quando se tratasse de bens destinados a consumo ou ativo fixo do estabelecimento. 
ao comércio), bem como quanto à habitualidade para a qualificação do contribuinte do imposto.

A bem da verdade não se trata de uma "exceção", já que consta do art. 155, §2º , IX, “a”, da Constituição, que o ICMS também incidirá sobre a entrada de bem ou mercadoria importados do exterior por pessoa física e jurídica, ainda que não seja contribuinte habitual do imposto, qualquer que seja a sua finalidade. Em outras palavras, a importação de bem (que não necessariamente é uma mercadoria) também constitui hipótese de incidência do referido imposto, mas para isso a Constituição precisou ser alterada.

A redação original do art. 155, §2 , IX, “a”, da Constituição Federal de 1988, previa a incidência do ICMS sobre a entrada de mercadoria importada do exterior ainda quando se tratasse de bens destinados a consumo ou ativo fixo do estabelecimento. Tal redação permitia concluir, contrario sensu, que a importação de bens por quem não fosse contribuinte do imposto não era passível de tributação, o que foi, inclusive, referendado pelo Supremo Tribunal Federal ao julgar o Recurso Extraordinário no $203.075-9^{250}$, onde restou afastada a incidência do ICMS em caso de importação de bem por pessoa física consumidora final.

Entretanto, por meio da Emenda Constitucional n ${ }^{0} 33 / 2001$, a alínea "a", do inciso IX, do $\S 2^{\circ}$, do art. 155, da Constituição foi alterada justamente para contemplar mais uma hipótese de incidência do ICMS, qual seja, a importação de bens ou mercadorias por pessoa física ou jurídica, independentemente de serem contribuintes habituais do imposto e da finalidade dada ao bem/mercadoria, tornando, assim, a jurisprudência do STF ultrapassada neste particular.

250 "RECURSO EXTRAORDINÁRIO. CONSTITUCIONAL. TRIBUTÁRIO. PESSOA FÍSICA. IMPORTAÇÃO DE BEM. EXIGÊNCIA DE PAGAMENTO DO ICMS POR OCASIÃO DO DESEMBARAÇO ADUANEIRO. IMPOSSIBILIDADE. 1. A incidência do ICMS na importação de mercadoria tem como fato gerador operação de natureza mercantil ou assemelhada, sendo inexigível o imposto quando se tratar de bem importado por pessoa física. 2. Princípio da não-cumulatividade do ICMS. Pessoa física. Importação de bem. Impossibilidade de se compensar o que devido em cada operação com o montante cobrado nas anteriores pelo mesmo ou outro Estado ou pelo Distrito Federal. Não sendo comerciante e como tal não estabelecida, a pessoa física não pratica atos que envolvam circulação de mercadoria. Recurso extraordinário não conhecido" (RE no 203.075-9, Ministro Relator Ilmar Galvão, DJ 05.08.1998). 
Outra exceção há de ser lembrada, qual seja, a prevista no art. 155, IX, "b”, da Constituição Federal, segundo a qual o ICMS incidirá sobre o valor total da operação quando mercadorias forem fornecidas com serviços desde que estes não estejam compreendidos na competência tributária dos Municípios. Isso porque, de acordo com a LC $n^{\circ}$ 116/03, os serviços constantes da lista anexa à lei, ainda que envolvam o fornecimento de mercadorias, não ficam sujeitos ao imposto estadual, o que equivale a dizer que os bens, a despeito de serem mercadorias, quando utilizados na prestação de serviços tributados pelo ISS não sofrerão a incidência do imposto estadual, salvo algumas exceções $^{251}$.

Ainda sob o ponto de vista da destinação dada ao bem, o comercialista José Xavier Carvalho de Mendonça define mercadoria como sendo:

\footnotetext{
"Tudo que pode ser objeto de comércio, vendido ou locado, é mercadoria. Mercadoria é a coisa comercial por excelência, na frase de Vidari. Nesse sentido fala-se em mercar, isto é, comprar e vender, especular, e de mercancia, significando mercadoria.

A palavra mercadoria não tem no Código Comercial sentido definido. Ora é empregada a antítese, a coisas móveis, dinheiro, papéis de crédito, efeito e valores, ora compreende qualquer objeto que, tendo valor de troca, pode entrar na circulação comercial.",252
}

Não obstante a supramencionada definição para fins comerciais, especificamente para fins fiscais, José Xavier Carvalho de Mendonça pregava que além da destinação mercantil, o bem deveria ser corpóreo para ser tido como mercadoria. ${ }^{253}$

O art. 191, do Código Comercial de $1850^{254}$, previa que a compra e venda mercantil era aquela realizada por comerciante e que tivesse por objeto bens móveis ou

${ }^{251}$ Nos termos do art. $2^{\circ}, V$, da LC $n^{\circ} 87 / 96$ e do art. $1^{\circ}, \S 2^{\circ}$, da LC $n^{\circ} 116 / 03$, algumas mercadorias necessárias à concretização da prestação de determinados serviços são tributadas pelo ICMS. São eles: itens 7.02, 7.05, 14.01, 14.03 e 17.11, da lista anexa à $\mathrm{LC} \mathrm{n}^{\circ} 116$.

${ }^{252}$ Tratado de Direito Comercial Brasileiro, vol. V, $1^{\text {a }}$ parte, São Paulo: Freitas Bastos, 1946, p. 28/30.

253 Tratado, op. cit., p. 28/30.

254 “Art. 191 - O contrato de compra e venda mercantil é perfeito e acabado logo que o comprador e o vendedor se acordam na coisa, no preço e nas condições; e desde esse momento nenhuma das partes pode arrepender-se sem consentimento da outra, ainda que a coisa se não ache entregue nem o preço pago. Fica entendido que nas vendas condicionais não se reputa o contrato perfeito senão depois de verificada a condição (artigo $\mathrm{n}^{\circ}$. 127).

É unicamente considerada mercantil a compra e venda de efeitos móveis ou semoventes, para os revender por grosso ou a retalho, na mesma espécie ou manufaturados, ou para alugar o seu uso; compreendendose na classe dos primeiros a moeda metálica e o papel moeda, títulos de fundos públicos, ações de companhias e papéis de crédito comerciais, contanto que nas referidas transações o comprador ou vendedor seja comerciante." 
semoventes. Note-se que o citado artigo fazia menção à qualificação daquele que participasse da operação comercial, ou seja, o comprador ou o vendedor deveriam ser comerciantes. Além disso, admitia que títulos de fundos públicos e ações de companhias, bens incorpóreos, poderiam ser objeto de compra e venda.

Com base nisso, Pedro Guilherme Accorsi Lunardelli ${ }^{255}$ defende que a definição de determinado bem como mercadoria para fins do ICMS, além da destinação mercantil, requer que uma das partes da operação seja comerciante. Para ele, a materialidade do bem não é mandatória, de modo que tanto o bem corpóreo como o incorpóreo podem ser qualificados como tal.

Todavia, em matéria de ICMS ninguém é mais autorizado que o Professor Alcides Jorge $\operatorname{Costa}^{256}$ e segundo ele, dois são os requisitos a serem preenchidos para que um bem seja classificado como mercadoria, quais sejam, (i) ser destinado ao comércio (ou seja, ser produzido e posto em circulação até ser adquirido pelo consumidor); e (ii) ser corpóreo:

\footnotetext{
“Toda cousa móvel corpórea produzida para ser colocada em circulação, ou recebida para ter curso no processo de circulação. (...) Mercadoria é toda cousa móvel corpórea; esta parte da definição dispensa explicações. Quando a definição dada fala em 'produzida para ser posta em circulação' e 'recebida para ter curso no processo de circulação', põe em destaque um elemento subjetivo, o do destino a ser dado à mercadoria; também a noção de mercadoria comumente aceita no direito comercial contém um elemento subjetivo."
}

Ao julgar o Recurso Extraordinário $\mathrm{n}^{\circ} 176.626$, a $1^{\text {a }}$ Turma do STF, sob a relatoria do então Ministro Sepúlveda Pertence, asseverou que o conceito de mercadoria efetivamente não inclui os bens incorpóreos, como os direitos em geral: mercadoria é bem corpóreo objeto de atos de comércio ou destinado a sê-lo.

Portanto, ante a atual ordem constitucional, estamos convencidos de que a corporalidade é requisito essencial para classificar determinado bem como mercadoria.

Aliás, é importante elucidar que ao prever que o ICMS incide sobre operações de circulação de energia elétrica, bem notoriamente incorpóreo, o constituinte quis incluí-la

\footnotetext{
255 "Se o objeto do negócio estiver representado por uma coisa corpórea, isto vem apenas somar ao conceito de mercadoria, na condição de uma característica acessória, e não definitória" (Tributação na internet, Revista Dialética de Direito Tributário, nº 59, São Paulo: Dialética, 2000, p. 83/84).

${ }^{256}$ ICM, op. cit., p. 99.
} 
no contexto de mercadorias, destacando-a como tal para fins de incidência do gravame estadual, justamente em razão do texto constitucional sugerir que mercadoria é todo bem corpóreo acompanhado do aspecto subjetivo quanto à sua destinação mercantil. Do contrário, não haveria necessidade de o constituinte tê-la indicado como mercadoria para fins de incidência do imposto (art. $155, \S 3^{\circ}$, da Constituição).

Livia de Carli Germano ${ }^{257}$ pontua que já faz muito tempo o STF entende que o conceito de mercadoria abrange apenas os bens corpóreos, pois quando do julgamento do Recurso Extraordinário no $31.737^{258}$, acerca da incidência do IVC sobre energia elétrica, a Suprema Corte afastou a incidência do imposto por questões de imaterialidade do bem. Além disso, segundo a pesquisadora:

\begin{abstract}
“A Constituição de 1946 previu então a criação do imposto único sobre operações com energia elétrica (art. 15, III, e parágrafo $2^{\circ}$ ), que não se confundia com o imposto sobre o consumo de mercadorias (previsto no art. 15, II). Com o advento da Constituição de 1988, os bens sujeitos ao imposto único, dentre eles a energia elétrica, foram alocados à competência dos Estados e do Distrito Federal, ou seja, a Constituição expressamente conferiu à energia elétrica o tratamento tributário de 'mercadoria'. Mas este é o único bem incorpóreo que pode ser alcançado pelo ICMS, tendo em vista a expressa previsão constitucional. Para todos os outros deve ser utilizado o conceito de mercadoria ordinariamente adotado no direito privado, que não alcança outros bens incorpóreos."
\end{abstract}

José Eduardo Soares de Mello ${ }^{259}$ afirma que, tradicionalmente, mercadoria é bem corpóreo da atividade empresarial do produtor, industrial e comerciante, tendo por objeto a sua distribuição para consumo, compreendendo-se no estoque da empresa, distinguindo-se das coisas que tenham qualificação diversa, segundo a ciência contábil, como é o caso do ativo permanente.

Consoante assevera o referido doutrinador, este conceito sofreu tempero constitucional ao submeter o fornecimento de energia elétrica (coisa incorpórea) ao âmbito de incidência do ICMS, enquadrando-o no espectro mercantil.

\footnotetext{
257 A tributação de músicas e vídeos comercializados na internet e entregues via download e streaming, in Oliveira, Ricardo Marizde; Schoueri, Luís Eduardo; Zilveti, Fernando Aurelio (coord.), Revista de Direito Atual, v. 27, Dialética: São Paulo, 2012, p. 447/448.

258 "IMPÔSTO DE VENDAS - Seu fato gerador é a compra - e - venda de mercadorias, isto é, coisa material e móvel, feita por produtor ou comerciante. Não incide, por isso, sobre a energia elétrica fornecida por empresa, que a produz ou distribui, ainda que sob a vigência da constituição de 1937." (STF, 2 ${ }^{\mathrm{a}}$ Turma, Ministro Relator Aliomar Baleeiro, RE n 31.737, DJ 12.10.1966).

259 ICMS, Teoria e Prática, São Paulo: Dialética, 2002, p. 18 e 20.
} 
Muito embora a Constituição não traga uma definição expressa do termo mercadoria, adotando-se a doutrina e a jurisprudência até aqui apresentadas, tem-se que a sua interpretação e compreensão sofreu pouca alteração ao longo dos anos, não obstante o avanço tecnológico, as mutações da sociedade e a necessidade de o Direito se adequar para tutelar as relações humanas. Todavia, com base no Código Civil de 2002, há quem possa tentar ampliar a definição de mercadoria.

Tal qual mencionado, o art. 191, do Código Comercial, expressamente, previa que compra e venda mercantil era aquela realizada por comerciante e que tivesse por objeto bens móveis ou semoventes, silenciando, portanto, sobre os imóveis.

Não obstante isso, sob a vigência do referido dispositivo e do Código Civil de 1916, ao julgar os Embargos de Divergência em Recurso Especial $n^{\circ} 156.384-\mathrm{RS}^{260}$ (DOU 26.03.2001), que tratava da incidência da COFINS sobre o faturamento decorrente das vendas de mercadorias e serviços (art. $2^{\circ}$, da Lei Complementar $n^{\circ} 70 / 91$ ) auferido pelas empresas dedicadas às operações de incorporação imobiliária, a $1^{\text {a }}$ Seção do Superior Tribunal de Justiça decidiu pela sua incidência por entender que os imóveis também podem ser considerados mercadorias.

O referido Tribunal entendeu que a interpretação do art. 191, do Código Comercial (que somente mencionava os bens móveis e os semoventes como mercadorias) deve levar em consideração as alterações históricas ocorridas ao longo do tempo e que por serem as

260 “TRIBUTÁRIO. COFINS. INCIDÊNCIA. COMERCIALIZAÇÃO DE IMÓVEIS.

- Artigo 195, inciso I, da Constituição Federal, conforme redação dada pela Emenda Constitucional n. $20 / 98$.

- A Lei n. 9.718, de 27.11.98, ---- a dispor que o faturamento corresponde à receita bruta da pessoa jurídica ----, foi recepcionada pela atual redação do artigo 195, inciso I, da Constituição Federal.

- A Lei n. 9.718/98 'estendeu o conceito constitucional de faturamento em relação a todas as pessoas jurídicas de direito privado' (cf. Vittorio Cassone, 'COFINS - Lei n. 9.718/98 - Validade e Alcance', in Repertório de Jurisprudência IOB, Tributário, Constitucional e Administrativo, n. 8/99, 1/13.411).

- O Excelso Supremo Tribunal Federal, em várias oportunidades, no que se refere às empresas vendedoras de mercadorias e/ou prestadora de serviços, quanto ao campo de incidência da COFINS ou do extinto FINSOCIAL, equiparou faturamento à receita bruta, o que desautoriza a conclusão de que faturamento havia sido empregado em sentido restrito.

- O imóvel é um bem suscetível de transação comercial, pelo que se insere no conceito de mercadoria.

- Não se sustém, data venia, nos dias que correm a interpretação literal do disposto no artigo 191 do Código Comercial e do artigo $19, \S 1^{\circ}$, do Regulamento n. 737. Em épocas de antanho, os imóveis não constituíam objeto de ato de comércio. Atualmente, tal não se dá, por força das Leis no s. 4.068/62 e 4.591/64.

- Embargos de Divergência rejeitados. Decisão por maioria.” 
incorporadoras imobiliárias empresas comerciais, os bens por elas comercializados são mercadorias.

Tal entendimento guarda coerência com a escrituração contábil destes bens, pois as incorporadoras imobiliárias registram-nos em conta do ativo circulante (estoque) ${ }^{261}$.

Não obstante isso, não se pode deixar de mencionar que nos termos do art. 156, II, da Constituição Federal, a transferência patrimonial dos bens imóveis, por razões de competência tributária, é hipótese de incidência do imposto municipal sobre a transmissão inter vivos de bens imóveis (ITBI).

Tendo em vista que o referido art. 191 foi revogado com o advento do novo Código Civil (lei $n^{\circ} 10.406 / 02$ ), há quem possa argumentar que a compreensão sobre mercadoria até aqui ilustrada pode requerer novas reflexões, já que nos termos do art. $966^{262}$ (que equivaleria ao citado art. 191 do Código Comercial) é considerado empresário quem exerce profissionalmente atividade econômica organizada para a produção ou a circulação de bens ou de serviços. Note-se que o dispositivo não faz menção à figura do comerciante, tão pouco menciona os bens móveis ou semoventes de outrora.

Elidie Palma Bifano ${ }^{263}$ pondera que a atividade econômica organizada para produzir ou fazer circular bens ou serviços objetiva ganhos e auferir lucros e que a produção e a circulação de bens com finalidade econômica, ainda que não sejam bens móveis ou semoventes, constituem a atividade empresária, muito embora faça a ressalva de que os bens imóveis, ainda que possam ser tidos como mercadorias para fins civis (considerando o teor do art. 966, do Código Civil), serão gravados pelo ITBI em caso de transferência de sua titularidade.

261 "Solução de Consulta da Secretaria da Receita Federal no 45 de 13 de dezembro de 2007 Assunto: Normas Gerais de Direito Tributário. Ementa: LUCRO PRESUMIDO. VENDA DE IMÓVEIS. BASES DE CÁLCULO. A pessoa jurídica tributada pelo lucro presumido, cujo objeto social envolva atividades imobiliárias, na venda de imóvel de seu Ativo Circulante deve considerar como receita bruta, para fins de apuração do IRPJ, da CSLL, da Contribuição para o PIS/Pasep e da Cofins, todo o valor da transação, ainda que o pagamento pelo imóvel alienado se dê, no todo ou em parte, mediante entrega de outro imóvel."

262 “Art. 966. Considera-se empresário quem exerce profissionalmente atividade econômica organizada para a produção ou a circulação de bens ou de serviços.

Parágrafo único. Não se considera empresário quem exerce profissão intelectual, de natureza científica, literária ou artística, ainda com o concurso de auxiliares ou colaboradores, salvo se o exercício da profissão constituir elemento de empresa."

263 O Negócio Eletrônico e o Sistema Tributário Brasileiro, São Paulo: Quartier Latin, 2004, p. 153. 
Sendo assim, pode-se dizer que a compreensão do termo mercadoria a partir de eventual interpretação mais ampla com base no novo Código Civil, não interfere na incidência do ICMS, já que o bem será considerado mercadoria desde que seja corpóreo; seja destinado à mercancia (sob a perspectiva do adquirente); e, desde que respeitada a repartição de competências tributárias dispostas na Constituição Federal.

Afinal, a destinação que é dada ao bem sob o ponto de vista do seu adquirente (elemento subjetivo: destinar-se à venda ou à revenda), atrelada ao fato de uma das partes da operação ser comerciante e à corporalidade da coisa, é que determinam tratar-se ou não de mercadoria.

\subsection{A mercadoria e o software (bem imaterial/intangível/incorpóreo)}

Consoante já demonstrado, toda mercadoria é um bem, mas nem todo bem é uma mercadoria.

Em escorreito parecer sobre a não incidência do ICMS-comunicação sobre licença para transmissão de programas mediante sinais transportados via satélite, o Professor Alcides Jorge Costa elucida que:

\footnotetext{
"De fato, não vem ao caso discutir a noção de bens e se nela se enquadram os direitos autorais, uma vez que, ao cuidar da classificação dos bens, o Código Civil e a citada lei $\mathrm{n}^{\circ}$ 5.988/73 qualificaram os direitos de autor como bens móveis (artigo 48, III), dentro da noção de Clóvis Beviláqua: 'Para o direito, bens são os valores materiais ou imateriais, que servem de objeto a uma relação jurídica.' (Código Civil Comentado, Rio de Janeiro, Livraria Francisco Alves, 1944, $7^{a}$ edição, vol. I, p. 38)."264
}

A afirmação do Professor Alcides continua atual. A despeito de a Lei no 5.988/73 (antiga lei de direitos autorais) ter sido revogada pela Lei $\mathrm{n}^{\circ}$ 9.610/98, os valores imateriais continuam sendo bens e os de cunho autoral permanecem classificados como bens móveis.

Em sendo o bem móvel destinado à mercancia (posto em circulação mercantil, partindo do produtor até o consumidor final) e sobretudo corpóreo, é fácil perceber que se trata de uma mercadoria para fins de incidência do ICMS, o que é corroborado pela doutrina e pela jurisprudência.

${ }^{264}$ ICMS - Comunicação - Parecer, Direito Tributário Atual, v. 16, Dialética: São Paulo, 2001, p. 11/12. 
Contudo, o mesmo não pode ser dito em relação a um bem imaterial, intangível/incorpóreo, como, por exemplo, um direito autoral, pois mesmo sendo um bem móvel o seu enquadramento como mercadoria não é tão simples assim.

Ao repartir as competências tributárias, a Constituição outorgou à União o poder de instituir, dentre outros, os impostos sobre a renda, sobre a importação, sobre a exportação, sobre os produtos industrializados; aos Estados e ao Distrito Federal outorgou, por exemplo, o poder de instituírem o ICMS; e, aos Municípios e ao Distrito Federal o de instituírem o ISS, além de outros.

Em complementação a isto, a Constituição Federal é detalhista quanto ao arquétipo de cada tributo, muito embora não traga definições explícitas, deixando a cargo do operador do Direito a tarefa de construir conceitos como ocorre com o que é dado às operações relativas à circulação de mercadorias.

Não obstante isso, a construção de conceitos constitucionais necessariamente deve levar em conta a repartição de competências tributárias (que permite a diferenciação entre operações relativas à circulação de mercadorias e os serviços de qualquer natureza) ${ }^{265}$, os conceitos advindos do direito privado e os conceitos pré-constitucionais que por ventura tenham sido acolhidos como conceitos constitucionais pressupostos.

$\mathrm{E}$, por assim dizer, no que tange à transmissão de bens imóveis, muito embora o STJ tenha concluído que os bens imóveis são mercadorias, para a Constituição Federal tais bens não o são, pois falta-lhes a mobilidade, caso contrário a transmissão de titularidade/propriedade de bens imóveis seria tributada pelo ICMS. Todavia, é sabido que as transmissões constituem hipótese de incidência do ITBI, de competência municipal.

Ao analisar a abrangência do vocábulo "produto" para fins de incidência do imposto de importação ${ }^{266}$ sobre coisas incorpóreas, Miguel Hilú Neto discorre sobre a importância da adequada compreensão da repartição de competências tributárias com vistas a atingir a definição conforme a Constituição. A despeito de a passagem abaixo

${ }^{265}$ Cf. NETO, Miguel Hilú, Imposto sobre importações e bens virtuais, in Schoueri, Luís Eduardo (coord.), Internet - O Direito na Era Virtual, Rio de Janeiro: Forense, 2001, p. 78.

${ }^{266}$ Nos termos do art. 153, I, da Constituição, compete à União instituir imposto sobre a importação de produtos estrangeiros. 
transcrita definir "produto" como bem móvel e corpóreo (excluído o incorpóreo), os seu conteúdo é planamente aplicável ao presente estudo, confira-se:

\begin{abstract}
“Ainda, já à época da promulgação da Carta e dos instrumentos legais infraconstitucionais que regularam o imposto sobre importações, havia bens sem existência corpórea que poderiam ser abarcados pelo conceito de produto, mas não o foram. Exemplos disso são as marcas, as patentes, o know-how, etc., que, embora passíveis de serem importados e, também, de serem incluídos no conceito vulgar de produto, não foram abarcados pela legislação (constitucional e infraconstitucional) atinente à matéria.

(...)

Reitere-se que, na linguagem comum, podem ser produtos tanto os bens corpóreos quanto os não corpóreos. Não raro se ouvem expressões como 'produtos jurídicos', 'produtos contábeis', 'produtos intelectuais', etc. Essa acepção mais larga, contudo, não foi adotada pela Constituição Federal, que diferenciou, claramente, produtos de serviços, de propriedade intelectual e industrial, etc.

Entende-se, portanto, que o sistema constitucional tributário brasileiro, ao se referir a produtos, utiliza o vocábulo em sentido estreito, ou seja, de bens corpóreos resultantes da transformação progressiva de elementos da natureza. Excluem-se, dessa forma, os bens que não têm existência física, como aqueles transferidos por download.

No que toca à legislação infraconstitucional, a interpretação sistemática do direito positivo leva a essa mesma conclusão. Iniciando pelo imposto sobre importações, veja-se que não há a previsão da tributação da internação de bens não corpóreos. O máximo que há, mediante previsão no Acordo sobre Valoração Aduaneira, é a inclusão, na base de cálculo do mencionado imposto, dos valores pagos a título de royalties e afins, como integrantes do bem corpóreo, não bens à parte. ${ }^{267}$
\end{abstract}

A partir da repartição de competências tributárias a Constituição diferenciou produto de bem, este de mercadoria, esta de serviço, este da propriedade intelectual ou da propriedade industrial e assim sucessivamente, justamente para impedir que os entes federados invadam a competência alheia.

Sendo assim, para fins de incidência do ICMS a mercadoria há de ser corpórea. O bem incorpóreo é, comumente, objeto de cessão de direitos e não de uma operação mercantil.

É bem verdade que os bens incorpóreos necessitam de suportes físicos para serem "perceptíveis", manuseados, para circularem fisicamente e para serem funcionais, porém estes não se confundem com aqueles.

267 Imposto, op. cit., p. 78/79. 
Quando o objeto do negócio havido entre as partes é um bem incorpóreo, os suportes físicos (sejam eles um compact disc (CD), um disquete, um computador, um telefone celular, um tablet, etc.) estão a serviço do bem imaterial, de modo que este não perde a sua intangibilidade ou a sua natureza por estar fixado em um suporte material.

A distinção clássica entre bens corpóreos e os incorpóreos é aquela dada por Gaio, segundo o qual os bens corpóreos são aqueles que podem ser tocados, enquanto os incorpóreos são criações do direito como, por exemplo, o usufruto. ${ }^{268}$

Sabe-se que o programa de computador é um bem intelectual por definição legal, mas o seu caráter utilitário de altíssimo valor agregado torna-o especial, pois proporciona o acionamento de máquinas e o manejo eletrônico de dados e nem por isso deixa de ser imaterial/intelectual/obra literária. De acordo com o art. $1^{\circ}$, da Lei $n^{\circ} 9.609 / 98$, trata-se de um conjunto organizado de instruções em linguagem natural ou codificada, contida em suporte físico de qualquer natureza, de emprego necessário em máquinas automáticas de tratamento da informação, dispositivos, instrumentos ou equipamentos periféricos, baseados em técnica digital ou análoga, para fazê-los funcionar de modo e para fins determinados.

José Eduardo Soares de Melo $^{269}$ defende que o programa é um bem digital, que não contempla as características de âmbito legal (art. 191, do Código Comercial) e constitucional (art. 155, $\S 3^{\circ}$ ), por tratar-se de produto intelectual, objeto de cessão de direitos, de distinta natureza jurídica.

A despeito de o conceito secular de mercadoria ter como justificativa um bem corpóreo, reconhecemos que os avanços tecnológicos impulsionam a modernização das relações humanas, afinal, hoje é possível transformar um bem corpóreo em dados digitais e transmiti-los por meio da internet. Essas modificações na realidade social exigem que o Direito se adeque seja legislando, seja flexibilizando interpretações, respeitando-se, obviamente, os princípios constitucionais. ${ }^{270}$

${ }^{268}$ Cf. GRECO, Marco Aurélio, Internet e Direito, São Paulo: Dialética, 2000, p. 82.

269 ICMS, op. cit., p. 18 e 20.

${ }^{270}$ Cf. PANDOLFO, Rafael, Tributação do Comércio Eletrônico: Análise da Incidência do ICMS, in Revista de Estudos Tributários vol. 33, Síntese: São Paulo, 2003, p. 145 
Entretanto, a adequada incidência do ICMS não depende apenas da eventual flexibilização do conceito de mercadorias, todos os critérios da sua regra-matriz de incidência tributária precisam ser preenchidos.

Fato é que o sistema jurídico brasileiro, de origem romano-germânica, não é dotado de condições estruturais para processar prontamente as interferências exercidas pelos sistemas econômico, político e social, por força de sua racionalidade própria, na medida em que, na regulação de condutas intersubjetivas, há que se respeitar diversos princípios constitucionais, sobretudo o da Legalidade para que não sejam produzidas normas jurídicas fundadas em critérios extrajurídicos. ${ }^{271}$

Toda mercadoria é um bem, mas nem todo bem é uma mercadoria. Aproximando esta assertiva do objeto do presente estudo nota-se a sua importância já que o software em si é um bem móvel, de natureza intelectual, protegido pelo direito autoral como se obra literária fosse e, portanto, incorpóreo.

\subsection{Impossibilidade jurídica do software e da respectiva licença de uso serem alcançados pelo ICMS}

De acordo com Roque Antonio Carrazza, o direito tributário é um direito de superposição, isto é, que pode captar conceitos e assimilar institutos, tais como lhe são fornecidos por outros setores do mundo jurídico. ${ }^{272}$

Segundo adverte Carrazza ${ }^{273}$, o direito tributário busca, "em outras categorias jurídicas, os dados e formas de que se utiliza, para fazer nascer os tributos (propriedade, mercadoria, compra e venda, transmissão de direitos imobiliários, etc.)".

Aliás, não é sem razão que o art. 110, do CTN ordena a preservação da definição, do conteúdo e do alcance de institutos, conceitos e formas de direito privado, utilizados, expressa ou implicitamente, pela Constituição Federal, pelas Constituições Estaduais ou

271 Cf. ARAUJO, Ana Clarissa Masuko dos Santos, ICMS no E-commerce e o Protocolo ICMS 21/2011-

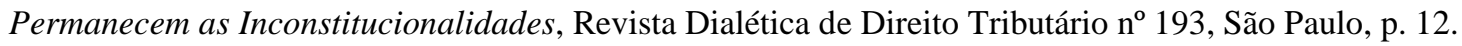

272 ICMS, op. cit., p. 44.

273 ICMS, op. cit., p. 44. 
pelas Leis Orgânicas do Distrito Federal ou dos Municípios, para definir ou limitar competências tributárias.

Tal entendimento é de extrema importância, pois é na seara do direito autoral que o direito tributário deve buscar (e respeitar) a natureza jurídica do software, o qual foi alçado à categoria de obra intelectual equiparada às obras literárias tuteladas pelo direito de autor, nos termos das Leis $n^{\circ}$ 9.609/98 e n n $^{\circ}$ 9.610/98, além dos Tratados internacionais que assim dispõem e dos quais o Brasil é signatário.

A contratação da utilização do software no Brasil deve, necessariamente, ocorrer por meio da licença de uso.

A referida licença consiste, tão somente, em uma concessão do direito de usar o programa de computador nos termos e prazos contratados, findo os quais cessa a legitimidade do usuário utilizá-lo.

Com base nas fartas lições doutrinárias de Carlos Alberto Bittar, diferentemente da cessão, a licença de uso não pressupõe a transferência dos direitos patrimoniais do autor. A primeira até poderia ser equiparada a uma operação mercantil (“compra e venda"), mas a segunda não se equipara. Diz-se "até poderia" se não fosse o fato de o programa de computador não poder ser considerado uma mercadoria, por se tratar de um bem incorpóreo.

A licença de uso mais se aproxima da locação de um bem móvel, uma obrigação de dar, de modo que o licenciado/usuário não se sub-roga nos direitos patrimoniais do autor da obra intelectual como se proprietário/autor fosse. Poderá, no máximo, tornar-se proprietário do suporte físico que o contempla.

Contudo, a "aquisição" do suporte físico que materializa a obra intelectual (o software) - considerada individualmente - não descaracteriza a concessão do direito de utilização de obra, pois não passa de um acessório para que a obrigação contratada entre o licenciador (autor) e o licenciado (usuário) se perfaça. 
A disponibilização do suporte físico contendo o programa de computador serve como atividade intermediária para que o licenciado tenha acesso ao programa. Em outras palavras, o CD, a mídia eletrônica ou qualquer outro meio físico que se preste a transferir ou entregar a obra intelectual em comento está a serviço da concretização da concessão da licença de uso.

Na maioria das vezes, a disponibilização do software em suportes físicos como, por exemplo, em CDs, postos à disposição de possíveis interessados/usuários/consumidores não se traduz em uma "compra e venda", pois - conforme fartamente exposto - a licença de uso constitui apenas a concessão do direito de uso e não a transferência jurídica de direitos patrimoniais de autor.

Vale lembrar que não são todas as relações jurídicas de concessão do direito de uso que requerem o suporte físico como meio para armazenar o programa. Ante a modernidade dos meios informáticos e o avanço da tecnologia, atualmente é cada vez mais comum a sua abstração e por meio da internet já é possível acessar o programa via download sem que seja necessária a sua materialização em suporte físico individual.

Aliás, Elidie Palma Bifano bem descreve o download como o meio pelo qual é possível transferir bens intangíveis eletronicamente:

\begin{abstract}
"O download de produtos digitais é ofertado aos usuários da internet, quer por sites especializados no provimento de tais produtos quer por fornecedores de tais bens, mediante a escolha em um catálogo mantido on-line. Download é a operação de transferência de uma cópia de um arquivo, de um computador remoto, para outro computador, através de um modem ou rede. Tecnicamente, a transferência é feita para o computador do adquirente, mais exatamente para o disco rígido (peça que fica no interior do microcomputador e que influenciada, eletricamente, retém informações gravadas em forma digital ou binária) ou para outro meio temporário (disquetes, minidiscos, CDs, etc.). Em matéria de comércio eletrônico implica a transferência de bens por meio eletrônico, geralmente de um servidor para computador de menor porte, via browser (programa), sem a presença de qualquer elemento material seja no que respeita ao próprio bem que está sendo adquirido, seja em relação aos elementos formais que sustentam a operação tais como contrato, documento fiscal e outros."274
\end{abstract}

Assim sendo, a disponibilização de (licenças de uso de) programas de computador não constitui uma operação mercantil passível de tributação pelo ICMS. Neste sentido, cite-se interessante passagem da obra ICMS, na qual Roque Antonio Carrazza analisa

${ }^{274}$ O Negócio, op. cit., p. 215. 
situação análoga à que ora se analisa (disponibilização de fitas de videocassete) e conclui pela não incidência do imposto:

\begin{abstract}
"Retornando desta digressão, podemos agora afirmar que a entrega de um bem corpóreo, em consequência de uma cessão de direitos, não acarreta a incidência de ICMS, mas, eventualmente, de outro imposto (a nosso ver, de um possível, porém ainda não cogitado, imposto sobre cessão de direitos, de competência da União).

Desenvolvendo a ideia, temos que a obrigação tributária só nasce diante da plena e cabal identificação do conceito do fato ocorrido com o conceito da hipótese de incidência. Assim, se o fato ocorrido é identificável como cessão de direitos não há como subsumi-lo à hipótese de incidência vender mercadorias.

Ceder direitos pressupõe a realização de atividades acessórias (atividades-meio), como as de distribuição de filmes em suporte de videocassete, fitas, compact discs, etc. Assim, estas não podem ser consideradas isoladamente, para efeito de incidência de imposto. Constitui erronia jurídica pretender desmembrar as inúmeras atividades-meio necessárias à cessão de direitos, como se fossem 'operações mercantis' parciais, para fins de incidência de ICMS.,"275
\end{abstract}

Elidie Palma Bifano ${ }^{276}$ possui entendimento diferente. Ao tratar da incidência do ICMS sobre a disponibilização do software comumente denominado standard (ou padrão ou "de prateleira" ${ }^{277}$ ) ela reconhece tratar-se de obra intelectual protegida pela Lei $n^{\circ}$ 9.610/98 (que dispõe sobre direito de autor), mas não refuta a incidência do imposto estadual por acreditar que assim teria decidido ${ }^{278}$ o Supremo Tribunal Federal quando do julgamento do Recurso Extraordinário nº 176.626-3/SP.

Contudo, ao tratar do software objeto de download pela internet com o objetivo de verificar a incidência do ICMS, a pesquisadora concluiu pela sua não-incidência:

\begin{abstract}
"O fato jurídico que sugere interesse, para fins de ICMS, é a transferência eletrônica de software, mediante a cobrança de preço. A incidência do ICMS, analisada no item 6.3 retro, levou à conclusão de que a lei tributa a circulação de mercadorias, consequentemente se o software fosse tido como mercadoria e estivesse sendo negociado através do canal da Internet, em operações de compra e venda, poder-se-ia dizer que tal operação estaria submetida a todas as regras pertinentes ao ICMS. Contudo, do ponto de vista técnico, o fornecedor de software por download apenas transfere instruções e, do ponto de vista jurídico, cede direitos de uso; ocorre que somente operações com mercadorias (bens móveis que se encontrem no mercado) negociadas (circulando) mediante intervenção de comerciantes, com intuito de lucro, é que se submetem à incidência do tributo, logo sendo o download apenas cessão de direitos e o software não passando de conjunto de instruções, bem incorpóreo insuscetível de
\end{abstract}

${ }^{275}$ ICMS, op. cit., p. 150/151.

${ }^{276}$ O Negócio, op. cit., p. 218/221.

277 Nomenclatura extraída do acórdão proferido pelo Supremo Tribunal Federal nos autos do Recurso Extraordinário $\mathrm{n}^{\circ}$ 176.626-3/SP.

${ }^{278}$ Consoante será visto adiante, não foi isso o que decidiu a Suprema Corte, muito embora a ementa do julgado sugira isto. 
ser considerado mercadoria, não há que se falar em tributação pelo ICMS de tais transações." 279

Seguindo grande parte da doutrina, vê-se que a pesquisadora adota como fator de discrímen para definir a tributação dos programas de computador, a forma como estes são disponibilizados aos usuários, muito embora acredite estar classificando o próprio objeto/bem.

De acordo com o entendimento de Bifano extraído do trecho acima transcrito, se "o software estivesse sendo negociado através do canal da internet, em operações de compra e venda, poder-se-ia dizer que tal operação estaria submetida a todas as regras pertinentes ao ICMS", mas por ser disponibilizado via download não há que se falar no imposto estadual, pois "sendo o download apenas cessão de direitos e o software não passando de conjunto de instruções, bem incorpóreo insuscetível de ser considerado mercadoria, não há que se falar em tributação pelo ICMS de tais transações".

A nosso ver, tal entendimento é equivocado. A forma ou o meio pelo qual os programas são entregues aos usuários não é o critério diferenciador que fará incidir ou não o ICMS, já que somente o preenchimento dos critérios da respectiva regra-matriz de incidência tributária fará irromper o dever de pagá-lo.

A passagem supratranscrita bem demonstra como muitos operadores do direito equivocam-se ao sustentar uma classificação de programas de computador sem se darem conta de que, a bem da verdade, estão a classificar a forma ou os meios pelos quais o software chega às mãos dos seus usuários.

É importante reafirmar que a Lei $n^{\circ} 9.609 / 98$ (lei do software) em nenhum momento classifica o programa de computador, apenas explicita que se trata de bem móvel, equiparado à obra intelectual protegida pela Lei $\mathrm{n}^{\circ}$ 9.610/98 (lei de direitos autorais), bem como ordena que o seu uso seja objeto de contrato de licença de uso.

Em outras palavras, o programa que é inserido em um suporte físico individual, negociado pela internet e entregue fisicamente ao interessado é idêntico ao programa que

${ }^{279}$ O Negócio, op. cit., p. 221. 
também é negociado pela internet, mas é entregue via download. Sendo assim, a forma de disponibilizar o programa não altera a sua natureza jurídica, não o torna mercadoria.

Da mesma forma que há programas que são postos à disposição dos interessados em grandes lojas de departamentos, como é o caso do software equivocadamente classificado como standard/padrão/“de prateleira", outros (e até mesmo os "de prateleira") são disponibilizados pela internet, porém o uso de qualquer um deles é regido por contrato de licença e todos eles continuam sendo bens móveis, intangíveis, intelectuais e protegidos pelo direito autoral.

A Lei $n^{\circ}$ 9.609/98 não faz distinção quanto à licença de uso de um ou de outro (mesmo porque a lei não os distingue). Tanto a utilização de um, quanto a do outro se dará da mesma forma: por meio de licença de uso.

Muito provavelmente na situação exposta por Bifano, a (con)cessão do direito de uso do programa será apresentada ao usuário pelo próprio software no momento da sua instalação (ou do download), para que com os seus termos aquele concorde. Trata-se de condição para o acesso e manuseio do bem, pois assim determina a Lei ${ }^{\circ}{ }^{9}$ 9.609/98.

Por conta disso não concordamos com Elidie Palma Bifano. Aliás, nos termos do art. $9^{\circ}$, da Lei $\mathrm{n}^{\circ}$ 9.609/98, o download não consiste na cessão de direitos de uso do programa. A partir da definição dada pela própria Bifano, transcrita linhas atrás, trata-se apenas do meio pelo qual o software é disponibilizado/entregue.

A (con)cessão de direitos de uso do programa se aperfeiçoa mediante a manifestação de anuência, tácita ou expressa, do usuário em relação às condições e termos previstos no contrato de licença de uso seja no caso de programa entregue via download, seja em caso de entrega física do suporte individual que o contenha.

Ao sustentar que o download também é um contrato de cessão de direito de uso, com o que não concordamos, Bifano, em nota de rodapé, informa que "o contrato somente será cessão de direitos se a relação jurídica for firmada entre o proprietário cedente e o 
cessionário-usuário, caso contrário, ocorrendo a relação indireta, o contrato será de exploração de direitos de terceiros, remunerado por royalties. ${ }^{280}$

Em que pese a posição sustentada, com ela também não podemos concordar pelas razões já expostas quando abordamos a aquisição derivada dos direitos patrimoniais de autor e rememoramos que mesmo no caso de software standard/padrão/“de prateleira” que comumente é posto à disposição dos usuários interessados em lojas de departamentos e até em supermercados, portanto, mediante a atuação de terceiros/intermediários, o contrato de licença de uso é firmado com o seu autor (ou com quem detém por via derivada os direitos patrimoniais de autor).

Hugo de Brito Machado é categórico e com ele concordamos: "Não sendo um bem corpóreo, o software efetivamente não é mercadoria, de sorte que se configura verdadeiro absurdo a exigência do ICMS sobre a sua aquisição". ${ }^{281}$

Somos da opinião de que os bens intelectuais, cuja existência imaterial impossibilita a sua tradição física, ensejam a figura da cessão/concessão de direitos autorais, de modo que, ao contrário da transferência de domínio/propriedade que caracteriza a alienação de bens corpóreos, quanto aos bens imateriais dá-se apenas a transferência do direito de exploração ou do uso do bem intelectual, a depender do que foi acordado entre as partes. ${ }^{282}$

Assim, conforme exposto, o programa de computador enquanto bem móvel, imaterial e protegido pelo direito de autor não constitui mercadoria, independentemente da forma como é disponibilizado ao usuário interessado.

Da mesma forma, a concessão do direito de uso de software não equivale a uma "compra e venda" dos direitos patrimoniais do autor ou a uma operação de circulação de mercadoria, pois não enseja a transferência jurídica do bem, mas tão somente a autorização de uso nos termos e condições previstas na licença, motivo pelo qual não há que se falar na incidência do ICMS.

\footnotetext{
${ }^{280}$ O Negócio, op. cit., p. 220.

281 MARTINS, Ives Gandra da Silva (coord.), Tributação na Internet, São Paulo: Revista dos Tribunais, 2001, p. 97.

282 Cf. WACHOWICZ, Marcos, Revolução, op. cit., p. 235.
} 


\subsection{Jurisprudência: uma análise critica do conteúdo decisório firmado no $\operatorname{RE~} \mathrm{n}^{0}$ 176.626-3}

Muito já se discutiu e ainda se discute sobre a incidência ou não do ICMS (e/ou do ISS) sobre a "aquisição" de software que, conforme visto, não se trata de uma compra e venda de mercadoria, mas de uma concessão de direitos (licença de uso).

Na década de 90, o STJ proferiu inúmeras decisões acerca do tema. Sob a relatoria do então Ministro Garcia Vieira, ao julgar o Recurso Especial n ${ }^{\circ}$ 39.797-9, em 15.12.1993, a $1^{\text {a }}$ Turma negou provimento ao pleito do Estado de São Paulo e afastou a incidência do ICMS sobre as transações que envolviam programas de computador ("larga escala" ou software "de prateleira") postos à disposição dos consumidores em loja de departamento.

Naquela ocasião, o STJ decidiu que o programa de computador não poderia ser considerado mercadoria por ser incorpóreo, por se tratar de uma obra intelectual, protegida pelo direito autoral, que não poderia ser confundido com o seu suporte físico e cuja disponibilização ao usuário deveria se dar por meio de contrato de licença de uso, distanciando-o, expressamente, da compra e venda (operação mercantil). ${ }^{283}$

Em 1996, a $2^{\text {a }}$ Turma do STJ, sob a relatoria do então Ministro Hélio Mosimann, ao julgar o Recurso Ordinário em Mandado de Segurança $n^{\circ}$ 5.934, divergiu do entendimento acima e decidiu pela incidência do ICMS sobre as transações com programas de computador disponibilizados em larga escala, distinguindo-os dos programas especialmente desenvolvidos para determinado usuário, que deveriam ser tributados pelo ISS. De acordo com o voto vencedor, restou decidido que:

\footnotetext{
"Ocorre, no entanto, que a atividade intelectual existe apenas na fabricação do software, pois no momento em que o usuário opera com estes programas, ele não está utilizando um serviço, mas sim uma mercadoria, que foi como todas as outras, elaborada a partir de ideias, produzidas industrialmente e postas à venda no mercado.

Desta forma, certo é que o programador presta serviços ao empresário que produz "software" e não ao usuário.

É bem de ver, outrossim, que há diferenciações entre os programas. Há aquele feito em massa, para ser utilizado por vários usuários indistintamente e nos limites de suas especificações (Windows, OS/2, Word...), como também o feito
}

${ }^{283}$ No mesmo sentido: Recurso Especial no $39.457-0-\mathrm{SP}$. 
por encomenda, visando matérias específicas para determinado usuário (programa de estoque de livros oceanográficos...).

Assim, os programas de massa (aplicativos), feitos por empresas em larga escala e de maneira uniforme são, a toda evidência, mercadorias, de livre comercialização no mercado, logo passíveis de tributação pelo ICMS.

Já os programas feitos especialmente para certo usuário exprimem verdadeira prestação de serviços, incidindo, portanto, o imposto sobre serviços - ISS.”

Note-se que a diferenciação feita pelo STJ entre os programas de computador se deu a partir da forma como são postos à disposição dos clientes interessados, se prontos e acabados em grandes quantidades ou se oferecidos de forma "personalizada". Contudo, a referida Corte não explorou a questão da licença de uso.

Um ano depois do julgamento supramencionado, o STJ rediscutiu a matéria ao julgar o Recurso Especial $n^{\circ}$ 123.022/RS, sob a relatoria do então Ministro Humberto Gomes de Barros e a despeito de o Tribunal ter mantido o entendimento quanto à incidência do ICMS sobre software disponibilizado em larga escala ("de prateleira"/standard) e do ISS sobre os desenvolvidos com fim específico para determinado usuário, a questão da licença de uso do programa foi apreciada com mais vagar. E é do respectivo acórdão que extraímos passagem elucidativa da sustentação oral realizada pelo patrono da empresa recorrente, Dr. Marcos Antonio Costa Souza, que buscava a não incidência do ICMS, mas restou vencido:

\footnotetext{
"O que acontece é um contrato no qual se estabelecem as condições, por prazo determinado ou não, com ou sem exclusividade, tanto num caso como no outro, tanto na hipótese daquele que encomenda uma obra, que é desenvolvida, cede-se o direito de uso. A propriedade do autor em função da própria legislação autoral permanece com o autor, cujos direitos patrimoniais pode ceder ou não, mas isso é matéria de contrato, e a licença de uso é uma forma de contrato. Pretende-se estabelecer que toda a comercialização é feita sempre mediante licença de uso ou contrato de cessão, que se assemelham bastante a este caso. Qualquer que seja a forma, seja para uso próprio, ou maciço, o que se comercializa é a licença.”
}

Em 1998, o Supremo Tribunal Federal julgou o Recurso Extraordinário n ${ }^{\circ}$ 176.6263 (também interposto nos mesmos autos do Recurso Especial n 39.797-9, já mencionado linhas atrás), que tratava da incidência ou não do ICMS sobre operação com software produzido em larga escala/software "de prateleira", e não conheceu do tal apelo extraordinário do Estado de São Paulo, mantendo o acórdão anteriormente proferido em favor da empresa recorrente (que havia afastado a incidência do tributo estadual) por entender que o conceito de mercadoria não contempla bens incorpóreos (como a software 
e, consequentemente, a respectiva licença de uso) e por não restar configurada a transferência jurídica do bem (direitos patrimoniais sobre a obra). Vejamos a sua ementa:

\begin{abstract}
"I. Recurso extraordinário: prequestionamento mediante embargos de declaração (Súm. 356). A teor da Súmula 356, o que se reputa não prequestionado é o ponto indevidamente omitido pelo acórdão primitivo sobre o qual 'não foram opostos embargos declaratórios'. Mas se, opostos, o Tribunal a quo se recuse a suprir a omissão, por entendê-la inexistente, nada mais se pode exigir da parte (RE 210.638, Pertence, DJ 19.6.98).

II. RE: questão constitucional: âmbito de incidência possível dos impostos previstos na Constituição: ICMS e mercadoria. Sendo a mercadoria o objeto material da norma de competência dos Estados para tributar-lhe a circulação, a controvérsia sobre se determinado bem constitui mercadoria é questão constitucional em que se pode fundar o recurso extraordinário.

III. Programa de computador ('software'): tratamento tributário: distinção necessária. Não tendo por objeto uma mercadoria, mas um bem incorpóreo, sobre as operações de 'licenciamento ou cessão do direito de uso de programas de computador' 'matéria exclusiva da lide', efetivamente não podem os Estados instituir ICMS: dessa impossibilidade, entretanto, não resulta que, de logo, se esteja também a subtrair do campo constitucional de incidência do ICMS a circulação de cópias ou exemplares dos programas de computador produzidos em série e comercializados no varejo - como a do chamado 'software de prateleira' (off the shelf) - os quais, materializando o corpus mechanicum da criação intelectual do programa, constituem mercadorias postas no comércio."
\end{abstract}

Uma leitura apressada da referida decisão pode levar o intérprete a uma conclusão equivocada e, desafortunadamente, muitos operadores do direito acabaram assim procedendo, de modo que a doutrina e a jurisprudência brasileira é farta em ponderações precipitadas no sentido de que o Supremo Tribunal Federal teria decidido pela incidência ${ }^{284}$ do ICMS ou do ISS de acordo com a "espécie" do software: (i) "de prateleira"/padrão; (ii) sob encomenda; ou, (iii) híbrido (adaptável ao cliente).

Para parte da doutrina e jurisprudência, o Supremo Tribunal Federal teria decidido que o ICMS incide sobre as transações com software "de prateleira"/padrão e que o ISS incide sobre as transações com software desenvolvido sob encomenda e híbrido. ${ }^{285}$

${ }^{284}$ Entendimento que decorre do trecho constante do acórdão proferido que, se considerado isoladamente, pode referendar o equivocado posicionamento: 'É esse 'direito de exclusivo' - que não é mercadoria, nem se aliena com o licenciamento de seu uso -, que se deve declarar fora do raio de incidência do ICMS, como exatamente concluíra, nos lindes do pedido, a decisão recorrida.

Dessa exclusão, entretanto, não resulta que de logo se esteja também a subtrair do campo constitucional de incidência do mesmo tributo a circulação de cópias ou exemplares de programas de computador produzidos em série e comercializados no varejo, isto é, do chamado 'software de prateleira'. (...)"

285 Aliás, em 1999, ou seja, no ano seguinte ao da prolação do acórdão do RE n 176.626-3, o STF rediscutiu a matéria (RE no 199.464-9) e sob o equivocado argumento de que já teria reconhecido a incidência do ICMS sobre a comercialização e a revenda de software "de prateleira"/padrão, deu provimento ao recurso do Estado de São Paulo e confirmou a incidência do imposto estadual sobre a produção $e$ comercialização em massa de exemplares do corpus mechanicum da obra intelectual que nele se materializa. 
O Recurso Extraordinário n ${ }^{\circ}$ 176.626-3 tem como pano de fundo a incidência ou não do ICMS sobre as operações de licenciamento ou de cessão de direito de uso de programas de computador advindas das operações com software "de prateleira"/padrão.

Neste aspecto, remetemo-nos aos argumentos quanto à natureza jurídica do citado instituto, aos ensinamentos de Carlos Alberto Bittar e às disposições das Leis nº 9.609/98 e 9.610/98, segundo os quais o uso de qualquer programa de computador deve se dar por meio de contrato de licença de uso.

Muito embora o Supremo Tribunal Federal, nos autos do RE n ${ }^{\circ} 176.626-3$, tenha referendado que não incide ICMS sobre operações de licenciamento ou de cessão de direito de uso de programas de computador, o que, a nosso ver, está correto, ao assim proceder, referendou a classificação tripartite de programas desenvolvida pela doutrina estrangeira que não é pautada na lei do software $\left(n^{\circ}\right.$ 9.609/98) e por conta disso registramos a nossa crítica. Afinal, o uso de qualquer programa de computador (independentemente de "classificação" ou "espécie") está indiscutivelmente atrelado ao mesmo contrato de licença.

A classificação dos programas de computador da forma como foi posta no acórdão proferido pelo Supremo Tribunal Federal pode levar o intérprete a concluir, equivocadamente, que a incidência ou não do ICMS ou do ISS está a depender da "espécie" do software, quando - na verdade - o que se discutiu foi a não incidência do ICMS sobre a concessão do direito de utilização de uma obra intelectual protegida pelo direito autoral. A licença de uso está presente em qualquer programa (seja ele padrão, elaborado sob encomenda ou adaptável ao cliente).

Assim, considerando que o ICMS - nos termos do acórdão do Supremo Tribunal Federal - não incide sobre as operações de licenciamento ou de cessão de direito de uso de programas de computador e considerando que todas as transações com programas de computador que se destinam ao uso estão atreladas a um contrato de licença, sejam eles software "de prateleira", sob encomenda ou híbridos, outra conclusão não se admite senão a de que o ICMS, em hipótese alguma, incidirá sobre licença de uso, independentemente da classificação que se pretenda dar ao programa. 
É por isso que propomos interpretar o acórdão do Recurso Extraordinário $\mathrm{n}^{\circ}$ 176.626-3 com mais vagar e acuidade, pois a sua ementa induz o intérprete a erro.

Além de ter referendado a tão comentada classificação tripartite ${ }^{286}$ de programas de computador desenvolvida pela doutrina estrangeira, a Suprema Corte entendeu que os bens incorpóreos não estão sujeitos à incidência do ICMS, nos seguintes termos: "não tendo por objeto uma mercadoria, mas um bem incorpóreo, sobre as operações de 'licenciamento ou cessão de direito de uso de programas de computador' - matéria exclusiva da lide efetivamente não podem os Estados instituírem ICMS", ${ }^{287}$

A bem da verdade, o Supremo Tribunal Federal reconheceu expressamente que nas situações com programas de computador sempre haverá direito autoral envolvido, o qual deve ser respeitado. É o que se depreende do seguinte trecho: "seja qual for o tipo de programa, contudo, é certo, não se confundirão a aquisição do exemplar e o licenciamento ou cessão do direito de uso, também presente até quando se cuide do software 'enlatado' ou de 'prateleira'."

E, por assim dizer, o Supremo Tribunal Federal decidiu que o programa de computador não pode se confundir com o corpus mechanicum que o materializa/corporifica e que este sim é passível de circulação como mercadoria e, consequentemente, de ser tributado pelo ICMS:

"O licenciamento, como disse, não se confunde com as operações realizadas com
o exemplar do programa. Nesse sentido, observa o já citado Rui Saavedra que,
verbis (ob. cit., p. 79/80):
‘..quando o software standard é licenciado - a licença é uma permissão para
fazer algo que de outro modo seria ilícito -, há na verdade dois: por um lado,
um contrato para que sejam fornecidas as manifestações físicas do software;
e por outro, um contrato para atribuição de uma licença de uso do software.

${ }^{286}$ Programas: padrão/ "de prateleira”; por encomenda; e, híbridos (adaptados ao cliente).

${ }^{287}$ Consta do acórdão do RE $n^{\circ} 176.626-3$, que: "O que individualiza o software em relação ao outros instrumentos a serviço da informação - assinala Rui Saavedra, em preciosa monografia acadêmica apresentada à Universidade de Coimbra ('A Proteção Jurídica do Software e a Internet, Don Quixote, Lisboa, 1998, p. 106/107) - 'é a sua natureza imaterial na medida em que ele mesmo é constituído por informação - a qual não tem substância tangível, e é, em si, um bem imaterial. O software apresenta-se, pois, como um produto, simultaneamente, utilitário e imaterial. Sendo o software um dos chamados 'bens informacionais' ou 'produtos de informação', ele não pode ser objeto duma proteção eficaz contra os atos dos não proprietários. Tal proteção só poderá relevar do Direito Intelectual, ou seja, através da organização de um 'direito de exclusivo' a favor daqueles que elaboram o software.

É esse 'direito de exclusivo' - que não é mercadoria, nem se aliena com o licenciamento de seu uso -, que se deve declarar fora do raio de incidência do ICMS, como exatamente concluíra, nos lindes do pedido, a decisão recorrida." 
contrato pelo qual o cliente é investido na posse do software será um contrato de compra e venda ou de doação se a propriedade sobre os meios físicos for transmitida ao licenciado; se não houver essa transmissão, tratar-se-á de um contrato de locação ou, porventura, de comodato. Mas o contrato de licença subsiste paralelamente, e é importante porque - como veremos - os produtores de software, após a entrega do exemplar do software, continuam preocupados em proteger os direitos de propriedade intelectual sobre $o$ software por eles criado, e em impor restrições ao uso do software entregue.'

De fato. O comerciante que adquire exemplares para revenda, mantendo-os em estoque ou expondo-os em sua loja, não assume a condição de licenciado ou cessionário dos direitos de uso que, em consequência, não pode transferir ao comprador: sua posição, ai, é a mesma do vendedor de livros ou de discos, que não negocia com os direitos do autor, mas com o 'corpus mechanicum de obra intelectual que nele se materializa. Tampouco, a fortiori, a assume o consumidor final, se adquire um exemplar do programa para dar de presente a outra pessoa. $\mathrm{E}$ é sobre essa operação que cabe plausivelmente cogitar da incidência do imposto questionado.

A distinção é, no entanto, questão estranha ao objeto desta ação declaratória, reduzido ao licenciamento ou cessão do direito de uso de programas de computador, bem incorpóreo sobre o qual, não se cuidando de mercadoria, efetivamente não pode incidir o ICMS;"

Aliás, tal interpretação foi confirmada pelo então Ministro Relator Octavio Gallotti que deferiu em parte a liminar da medida cautelar da ADIN n ${ }^{\circ} 1.945-7^{288}$, por entender ser constitucional a incidência do ICMS apenas "sobre operações de circulação de cópias ou exemplares de programas de computador produzidos em série e comercializados no varejo, não abrangendo o licenciamento ou cessão de uso dos mesmos" ${ }^{\text {,289 }}$. Em outras palavras, a partir de uma interpretação conforme a Constituição, o então Ministro reafirmou o conceito de mercadoria para fins do imposto estadual, excluindo o que nele não se enquadraria.

A apreciação do pedido de medida cautelar da ADIN nº 1.945 demorou 11 anos para ser concluída ${ }^{290}$ e ao longo dos debates havidos no Supremo Tribunal Federal, na

288 Impetrada pelo Partido do Movimento Democrático Brasileiro-PMDB contra diversos dispositivos da Lei $\mathrm{n}^{\circ} 7.098 / 98$, do Estado do Mato Grosso, dentre eles s art. $2^{\circ}, \S 1^{\circ}$, VI e art. $6^{\circ}, \S 6^{\circ}$ :

"Art. $2^{\circ}$ - O imposto incide sobre:

(...)

$\S 1^{\circ} \mathrm{O}$ imposto incide também:

(...)

VI - sobre as operações com programa de computador - software -, ainda que realizadas por transferência eletrônica de dados."

"Art. $6^{\circ}$ - A base de cálculo do imposto é:

(...)

$\S 6^{\circ}$ Integra a base de cálculo do ICMS, nas operações realizadas com programa de computador software - qualquer outra parcela debitada ao destinatário, inclusive o suporte informático, independentemente de sua denominação."

289 E por conta disso, o então Ministro Relator, mediante interpretação conforme a Constituição, fez constar do seu voto que a base de cálculo do ICMS deveria levar em consideração a restrição quanto a não incidência do ICMS sobre licenciamento ou cessão de uso dos programas de computador.

290 A ADIN foi impetrada em 1999 (logo após a edição da Lei no 7.098/98) e a apreciação da respectiva medida cautelar somente foi concluída em 26.05.2010. 
sessão de julgamento ocorrida em 26.05.2010, que culminou com o seu indeferimento, os Ministros se mostraram preocupados com os efeitos que o deferimento da medida poderia causar ante ao desaparecimento do periculum in mora, bem como em razão de a Lei do Estado do Mato Grosso ter vigorado com presunção de constitucionalidade nesse longo período.

O Ministro Gilmar Mendes também ponderou que a análise da medida cautelar relacionava-se com o próprio mérito, que - a seu ver - merecia maior reflexão, pois a tributação das transações com programas de computador obtidos por meio de download poderia refletir diretamente na tributação do comércio eletrônico como um todo. Assim, o indeferimento da medida cautelar se deu em razão de "conveniência política" e não por questões de constitucionalidade.

A despeito de ter contrariado o anterior deferimento da liminar (pautado no entendimento firmado no RE $\mathrm{n}^{\circ}$ 176.626-3, em que restou decidido que o ICMS não incide sobre a concessão de direito de uso do programa e que o imposto apenas incide sobre o valor do seu suporte material, este sim mercadoria, passível de transferência jurídica), o indeferimento da medida cautelar da $\operatorname{ADIN} n^{\circ} 1.945$ não objetivou alterar o entendimento da Corte sobre a matéria, mas apenas postergar a análise do seu mérito (e/ou a reanálise do que restou decidido anteriormente), sob o argumento de que o tema merece uma maior reflexão ${ }^{291}$.

Enquanto o Supremo Tribunal Federal não decidir o mérito da ADIN nº 1.945/MT, é possível demonstrar que o ICMS não incide sobre a licença de uso de programa de computador por ser bem imaterial, incorpóreo, que não constitui mercadoria e que em razão da respectiva licença de uso não ensejar a transferência jurídica do bem (propriedade intelectual), não há que se falar na incidência do imposto.

${ }^{291}$ Se o STF demorou 11 anos para indeferir a medida cautelar na ADIN, sob o argumento de que o tema merece uma maior reflexão, quanto tempo mais a Corte levará para julgar o mérito da ação? 
Assim, outra conclusão não se admite senão a de que nas transações com software o ICMS só pode incidir sobre o valor da operação referente à circulação do suporte físico que materializa o bem intelectual. ${ }^{292}$

Todavia, inúmeras são as decisões judiciais em sentido contrário, que não alcançam o verdadeiro conteúdo decisório firmado pelo STF quando do julgamento do RE $\mathrm{n}^{\circ}$ 176.626-3 e decidem pela incidência do ICMS sobre operações de "aquisição" de software "de prateleira", sem se darem conta de que tais operações não constituem compra e venda, mas mera obtenção de licença de uso de um bem imaterial, de um direito autoral ainda que inserido em um suporte físico meramente acessório.

\subsection{Repercussões em razão da entrega do software por negócio eletrônico direto}

A despeito da acertada decisão proferida pelo Supremo Tribunal Federal nos autos do Recurso Extraordinário no 176.626-3 nos termos acima expostos, há Estados como, por exemplo, o Estado do Mato Grosso, que determinam que sejam tributadas pelo ICMS as operações com programa de computador, ainda que realizadas por transferência eletrônica de dados e que a base de cálculo do imposto seja qualquer parcela debitada ao destinatário, inclusive o suporte informático, independentemente de sua denominação (Lei $\mathrm{n}^{\circ}$ 7.098/98, objeto da ADIN nº 1.945/MT).

Outros, porém, como o Estado de São Paulo, determinam a incidência do imposto apenas sobre o valor do suporte informático que o contempla, o que permite dizer que estes reconhecem a não incidência do imposto sobre o valor correspondente à contraprestação pela licença de uso.

O Decreto paulista $n^{\circ} 51.619 / 07$, prevê que na operação realizada com programa para computador, personalizado ou não, o ICMS será calculado sobre uma base de cálculo que corresponderá ao dobro do valor de mercado do seu suporte informático.

${ }^{292}$ Muito embora o acórdão do RE no 176.626-3 (e as demais decisões que o seguem) não esclareça como se dá o cálculo do ICMS, ou seja, se a base de cálculo deve ser composta só pelo valor da mídia/suporte físico. 
A incidência do imposto apenas sobre o valor do suporte informático é coerente com a regra-matriz de incidência do ICMS, já que apenas o suporte que materializa o programa de computador é mercadoria passível de ser objeto de uma operação de circulação (transferência jurídica).

A despeito de grande parte da doutrina interpretar o acórdão proferido nos autos do $\operatorname{RE~} n^{\circ} 176.626-3$ de forma equivocada, uma leitura com mais vagar permite concluir que a referida decisão está em consonância com o tratamento que é dado pela União em relação ao imposto de importação incidente sobre a importação de software padrão/standard/“de prateleira".

A Portaria MF nº 181/89 (ainda em vigor) estabelece que a base de cálculo do imposto de importação incidente sobre o suporte informático, que não abrange o custo ou o valor do programa desde que este custo ou valor conste no documento de aquisição destacadamente do custo ou do valor do suporte físico propriamente dito.

$\mathrm{O}$ art. $7^{\circ}$, da Instrução Normativa SRF $\mathrm{n}^{\mathbf{0}}$ 327/03, que estabelece normas e procedimentos para a declaração e o controle do valor aduaneiro de mercadoria importada, também determina que o valor aduaneiro de suporte informático que contenha dados ou instruções (software) para equipamento de processamento de dados será determinado considerando unicamente o custo ou o valor do suporte propriamente dito, desde que o custo ou o valor dos dados ou instruções esteja destacado no documento de aquisição.

A Secretaria da Receita Federal também já emitiu diversas Soluções de Consulta no mesmo sentido, confira-se:

“SOLUÇÃO DE CONSULTA No 95 de 09 de maio de 2012

ASSUNTO: Imposto sobre a Importação - II EMENTA: SOFTWARE. VALOR ADUANEIRO. BASE DE CÁLCULO. INEXISTÊNCIA DE SUPORTE FÍSICO. AUSÊNCIA DE BASE NORMATIVA PARA A TRIBUTAÇÃO. Na importação de programas de computador (softwares), seja na modalidade de cópia única ou na modalidade de cópias múltiplas, é considerado unicamente o custo ou valor do suporte físico propriamente dito na determinação do valor aduaneiro, desde que o custo ou o valor dos dados, programas ou aplicativos esteja destacado do custo ou valor do suporte físico no documento de aquisição. Nos casos em que não há suporte físico para movimentação do programa, não há base normativa para a tributação da operação pelo Imposto de Importação, uma vez que o valor aduaneiro da operação (e, conseqüentemente, a base de cálculo do imposto) não pode ser determinado." 
"SOLUÇÃO DE CONSULTA N $\mathrm{N}^{\circ} 421$ de 30 de novembro de 2010 $\begin{array}{lllll}\text { ASSUNTO: } & \text { Imposto } & \text { sobre } & \text { a } & \text { Importação } \\ \text { EMENTA: } & \text { SOFTWARE } & \text { (PROGRAMAS } & \text { DE II }\end{array}$ TRANSFERÊNCIA POR MEIO ELETRÔNICO (DOWNLOAD). Não há base legal para a incidência do Imposto sobre a Importação na aquisição de software transferido do exterior ao adquirente nacional por meio ele8trônico (download), sem a utilização, portanto, de suporte físico."

"SOLUÇÃO DE CONSULTA No 63 de 29 de Julho de 2002

ASSUNTO: Imposto sobre a Importação - II EMENTA: IMPORTAÇÃO DE SOFTWARE. Consideram-se mercadorias os programas de computador (software) na modalidade de cópias múltiplas, produzidos em escala e de maneira uniforme, colocados no mercado para aquisição por qualquer interessado. Na importação desse software será considerado unicamente o custo ou o valor do suporte físico propriamente dito na determinação do valor aduaneiro, desde que o custo ou o valor dos dados, programas ou aplicativos esteja destacado do custo ou valor do suporte físico no documento de aquisição. Esse tratamento não se aplica, porém, à importação de software que utiliza como meio físico um "chip" (circuito integrado), devendo incidir Imposto de Importação e IPI sobre o software e o meio físico.”

Ante ao reconhecimento da não incidência do gravame sobre as operações de licenciamento ou de concessão de direito de uso de programas de computador, muito embora o Supremo Tribunal Federal não tenha reduzido a termo qual seria a base de cálculo do ICMS em operações envolvendo a obtenção de licença de uso de software "de prateleira" e posto à disposição em lojas de departamentos, por exemplo, pode-se dizer que é adequada a forma adotada pela União, ou seja, que determina como base de cálculo (valor aduaneiro) do imposto de importação apenas o valor do suporte físico.

$\mathrm{Na}$ atualidade, muito se discute sobre a incidência do ICMS sobre as operações de comércio eletrônico direto (download) de bens intangíveis e que não possuem suporte físico individualizado, bem como sobre aquelas que se perfazem mediante o comércio eletrônico indireto de bens tangíveis que, adquiridos por meio da internet, são entregues fisicamente no local indicado pelo comprador/adquirente.

A evolução tecnológica e as mutações das relações sociais desenvolveram outros meios de aperfeiçoar negócios jurídicos. A tradicional importação (movimentação física) já não é a única maneira de trazer produtos, bens e mercadorias para o território brasileiro. Determinados bens podem ser convertidos em conteúdo digital e disponibilizados por transferência eletrônica de dados pela internet.

Em que pese o comércio eletrônico não seja objeto do presente estudo, entendemos por bem tecer mais algumas palavras sobre a não incidência do ICMS sobre as transações 
que envolvem a disponibilização do software por meio eletrônico de dados (download), denominado pela doutrina de "comércio eletrônico direto"293.

Além das dificuldades em se definir bens intangíveis como mercadorias para fins de incidência do imposto estadual, sob o ponto de vista tributário, os maiores problemas do comércio eletrônico direto dizem respeito à legislação do ICMS, notadamente quanto à inexistência de saída física da mercadoria. ${ }^{294}$

Agregue-se a isso, a ausência de previsão na LC nº 87/96 que permita a tributação das operações mercantis de bens intangíveis ${ }^{295}$. Ademais, caso seja feita uma interpretação extensiva equiparando-se a transmissão de dados a uma operação relativa à circulação de mercadoria, tal interpretação encontra óbice no art. 110, do CTN. ${ }^{296}$

Nem se diga que por analogia seria possível equiparar a circulação de mercadoria à transmissão eletrônica de dados com vistas a tributar as transações eletrônicas via download, pois tal instituto só pode ser usado restritivamente, de acordo com o que dispõe o art. 108 , I e $\$ 1^{\circ}$, do CTN. ${ }^{297}$

Atualmente, tanto a Constituição quanto a $\mathrm{LC} \mathrm{n}^{\circ}$ 87/96 não respaldam a incidência do ICMS sobre as transações eletrônicas de dados, de modo que a ampliação da incidência deverá ser feita somente através de emenda constitucional. Isso porque nada impede que a Lei Maior altere o conceito de direito privado para fins tributários, como já faz com o ouro, um metal que é considerado ativo financeiro (art. $153, \S 5^{\circ}$, da $\mathrm{CF} / 88$ ), ou então que venha a equiparar a transmissão de dados digitalizados à circulação de mercadorias. ${ }^{298}$

Alternativamente e diante da atual ordem constitucional, havendo manifestação exterior de riqueza (capacidade contributiva), a União poderá criar um imposto sobre a cessão de direitos (obtida ou não via download), com base na sua competência residual.

${ }^{293}$ Pelas razões já expostas, a expressão comércio eletrônico de dados não é apropriada para expressar a obtenção de software por meio de download, pois tal operação comumente diz respeito à obtenção da autorização do seu uso (licença de uso), salvo nos casos em que é pactuada a própria aquisição dos direitos patrimoniais de autor sobre o referido bem intelectual (que é equiparado à obra literária e protegido pelo direito autoral).

294 Cf. PANDOLFO, Rafael, Tributação, op. cit., p. 139.

295 Conforme já dito anteriormente e com base na doutrina civilista, os bens intangíveis não são postos no comércio; não são objeto de "compra e venda", mas de cessão de direitos.

296 Cf. PANDOLFO, Rafael, Tributação, op. cit., p. 140.

297 Cf. PANDOLFO, Rafael, Tributação, op. cit., p. 140.

298 Cf. PANDOLFO, Rafael, Tributação, op. cit., p. 146. 


\section{IMPOSTO SOBRE SERVIÇOS DE QUALQUER NATUREZA}

\subsection{Histórico legislativo}

Sob a égide da Constituição de 1946, a Emenda Constitucional nº 18/65 suprimiu o antigo imposto de indústrias e profissões outorgando poderes aos Municípios para a instituição do imposto sobre serviços de qualquer natureza (ISSQN, doravante ISS), não compreendidos na competência da União e dos Estados e cujos critérios seriam estabelecidos em lei complementar.

Dois anos depois, sobreveio a Constituição de 1967 que manteve a competência dos Municípios para instituir o imposto sobre serviços de qualquer natureza definidos em lei complementar e não compreendidos na competência tributária da União ou dos Estados.

Assim, na vigência da Constituição de 1967, foi editado o Decreto-lei no 406/68 que normatizava a instituição e exigência do ISS em âmbito nacional, além de trazer consigo uma lista dos serviços que poderiam ser tributados pelos Municípios.

Com a promulgação da Constituição de 1988, o ISS permaneceu no âmbito da competência tributária dos Municípios em caráter residual, não incidindo sobre os serviços gravados pelo ICMS, nos termos do art. 156, III $^{299}$. Os arts. $32, \S 1^{\circ}$ e 147 , da Constituição asseguram ao Distrito Federal a competência para instituir e exigir o ISS.

O Decreto-lei n 406/68 foi recepcionado com status de lei complementar pela atual Carta Magna e vigorou, no que tange às disposições relativas ao ISS, até o advento da LC $n^{\circ} 116 / 2003$ que, assim como o citado DL, é lei de âmbito nacional que traz as diretrizes gerais do ISS a serem observadas pelos Municípios quando da instituição do imposto nos seus respectivos territórios. Assim, somente os serviços listados na lista anexa à referida lei podem ser tributados pelo imposto.

\footnotetext{
299 “Art. 156. Compete aos Municípios instituir impostos sobre:

(...)

III - serviços de qualquer natureza, não compreendidos no art. 155, II, definidos em lei complementar."
} 
A LC $n^{\circ} 116$, publicada em 01.08.2003, derrogou o Decreto-lei nº 406/68 e, além de dispor sobre o local onde se considera prestado o serviço e o imposto devido ${ }^{300}$, inovou ao estabelecer que o imposto incide sobre serviço proveniente do exterior do País ou cuja prestação se tenha iniciado no exterior do País. ${ }^{301}$

Para a finalidade do presente estudo, é importante ressaltar que a elaboração de programas de computadores e o licenciamento ou a cessão de uso de programas de computador $^{302}$ constam da lista anexa à $\operatorname{LC~}^{\circ}$ 116/03, o que legitima os Municípios instituírem o gravame sobre tais atividades. A Lei no 13.701/03, do Município de São Paulo, por exemplo, prevê a incidência do ISS sobre as referidas atividades.

Portanto, o legislador considerou que a elaboração de programas de computadores e o licenciamento ou a cessão de uso de programas de computador configuram prestação de serviço e, considerando que há a possibilidade de o imposto incidir sobre a "importação de serviço", pode-se dizer que os pagamentos remetidos ao exterior, como contraprestação pelas citadas atividades, podem sofrer a incidência do gravame municipal.

Contudo, consoante será esmiuçado na sequência, o simples fato de o licenciamento ou a cessão de uso de programas de computador constar da lista dos serviços tributáveis não assegura tratar-se de uma prestação de serviço propriamente dita. Há que se analisar a sua natureza jurídica, compreender o seu conceito, bem como verificar se o instituto guarda identidade com o conceito de serviço comumente admitido pela doutrina e pela jurisprudência.

300 Alberto Macedo pontua que "embora tenha vindo com a intenção de pacificar a questão, procurando contribuir para a mitigação da guerra fiscal entre Municípios, tem sido questionada, assim como o diploma normativo vigente anteriormente, o Decreto-Lei no 406, de 31 de dezembro de 1968, por parte de alguns Municípios, contribuintes e doutrinadores, que entendem haver uma inconstitucional alteração do critério espacial." (O critério espacial do ISS nas prestações de serviço intermunicipais, Bergamini, Adolpho e Bomfim, Diego Marcel (coord.), in Comentários à lei complementar $n^{o} 116 / 03-D e$ advogados para advogados, São Paulo: MP Editora, 2009, p. 294).

301 “Art. $1^{\circ} \mathrm{O}$ Imposto Sobre Serviços de Qualquer Natureza, de competência dos Municípios e do Distrito Federal, tem como fato gerador a prestação de serviços constantes da lista anexa, ainda que esses não se constituam como atividade preponderante do prestador.

$\S 1^{\circ} \mathrm{O}$ imposto incide também sobre o serviço proveniente do exterior do País ou cuja prestação se tenha iniciado no exterior do País.

(...)"

302 Nos termos dos itens 1.04 e 1.05, da lista anexa à LC n ${ }^{\circ} 116 / 03$, o ISS incide sobre a elaboração de programas de computadores (inclusive de jogos eletrônicos) e sobre o licenciamento ou cessão de direito de uso de programas de computação. 


\subsection{Regime jurídico-tributário e regra-matriz de incidência tributária do ISSQN}

Assim como o ICMS, o ISS possui natureza tipicamente fiscal e é desvinculado de qualquer atuação estatal.

Sendo de competência municipal e distrital, o ISS é devido ao Município onde estiver localizado o estabelecimento prestador ${ }^{303}$, salvo em relação a determinados serviços expressamente previstos em lei cujo imposto é devido ao Município onde são executados.

A competência tributária dos Municípios e do Distrito Federal decorre do próprio princípio constitucional da autonomia municipal (art. 30) que assegura a tais entes federados autonomia financeira, permitindo que instituam o imposto sobre fatos jurídicos tributários ocorridos nos seus territórios.

O imposto é devido pelo prestador do serviço, podendo a lei atribuir a terceiro o dever de retê-lo e recolhê-lo.

A base de cálculo do imposto é o preço do serviço e a alíquota pode variar entre $2 \%$ e $5 \%{ }^{304}$. A lei ${ }^{305}$ também admite uma forma de cálculo diferenciada (preço fixo "por profissional") para as sociedades uniprofissionais e/ou para os profissionais que exerçam atividades legalmente regulamentadas.

${ }^{303}$ Segundo Bernardo Ribeiro de Moraes, "o essencial, para a caracterização do estabelecimento, é essa manifestação material em que a pessoa se situa no espaço em que exista um centro de ocupação habitual. Sem essa manifestação do exercício de atividades, ou esse núcleo de ocupações habituais, inexiste estabelecimento." (Doutrina e prática do imposto sobre serviços, São Paulo: RT, 1975, p. 489).

${ }^{304}$ Consoante determina o art. 88, do ADCT e o art. $8^{\circ}$, da LC n ${ }^{\circ} 116 / 03$.

${ }^{305}$ No que tange ao recolhimento do ISS por sociedades uniprofissionais, ainda vigora o art. $9^{\circ}$, do DL ${ }^{\circ}$ 406/68: "Art. $9^{\circ}$ - A base de cálculo do imposto é o preço do serviço:

$\S 1^{\circ}$ - Quando se tratar de prestação de serviços sob a forma de trabalho pessoal do próprio contribuinte, o imposto será calculado, por meio de alíquotas fixas ou variáveis, em função da natureza do serviço ou de outros fatores pertinentes, nestes não compreendida a importância paga a título de remuneração do próprio trabalho.

(...)

$\$ 3^{\circ}$ - Quando os serviços a que se referem os itens $1,4,8,25,52,88,89,90,91$ e 92 da lista anexa forem prestados por sociedades, estas ficarão sujeitas ao imposto na forma do $\S 1^{\circ}$, calculado em relação a cada profissional habilitado, sócio, empregado ou não, que preste serviços em nome da sociedade, embora assumindo responsabilidade pessoal, nos termos da lei aplicável." 
Os serviços tributáveis são os previstos na lista anexa à LC no 116/03, de modo que os que dela constam, ainda que sejam prestados com o fornecimento de mercadorias, ficam sujeitos ao imposto municipal, salvo nos casos excepcionais expressamente previstos na lei.

Consoante pacificado pela doutrina ${ }^{306}$ e jurisprudência ${ }^{307}$, a referida lista deve ser interpretada taxativamente, muito embora seja admissível a interpretação extensiva quanto aos serviços mencionados nos subitens.

A expressão "e congêneres" acrescida ao final de alguns subitens indica que o imposto também incide sobre serviços que guardam relação com as demais descrições do subitem, ainda que não expressamente mencionados.

Diferentemente do ISS incidente sobre os serviços prestados no mercado nacional que é considerado devido, via de regra, ao Município onde se localiza o estabelecimento prestador, nos termos do art. $3^{\circ}$, da $\operatorname{LC} n^{\circ} 116 / 03^{308}$, o gravame incidente sobre os serviços importados não leva em consideração o local da prestação ou do estabelecimento prestador, mas o do seu resultado, assim entendido como o local onde o serviço pode ser usufruído, local em que está localizado o seu beneficiário, não necessariamente o seu contratante.

306 "De acordo com Aires F. Barreto, "tributáveis são os serviços descritos nos subitens e não os gêneros referidos nos grupos que os aglutinam, porque esse entendimento decorre da estrutura própria da lista. Com efeito, se assim não fosse, despiciendos seriam todos eles; bastaria listar os vários grupos, sem necessidade de referir-se aos respectivos subitens" (ISS na Constituição e na Lei, $3^{\mathrm{a}}$ edição, São Paulo: Dialética, 2009).

307 "TRIBUTÁRIO. AGRAVO REGIMENTAL. ISSQN. LISTA DE SERVIÇOS. TAXATIVIDADE. SÚMULA 7/STJ. 1. Embora taxativa em sua enumeração, a Lista de Serviços admite interpretação extensiva, dentro de cada item, para permitir a incidência do ISS sobre serviços correlatos àqueles previstos expressamente. Precedentes do STF e do STJ. 2. Necessidade de reexame do contexto fáticoprobatório para constatar-se se as atividades que se pretende tributar efetivamente se enquadram nos itens 95 e 96 da lista anexa ao Decreto-Lei 406/68.Súmula 7/STJ. 3. Agravo regimental não provido." (STJ, AgRg no REsp. no 1.089.914/RJ, Rel. Min. Castro Meira, DJe 18/12/2008).

"CONSTITUCIONAL. TRIBUTÁRIO. ISS. LEI COMPLEMENTAR: LISTA DE SERVIÇOS: CARÁTER TAXATIVO. LEI COMPLEMENTAR 56, DE 1987: SERVIÇOS EXECUTADOS POR INSTITUIÇÕES AUTORIZADAS A FUNCIONAR PELO BANCO CENTRAL: EXCLUSÃO. I. - É taxativa, ou limitativa, e não simplesmente exemplificativa, a lista de serviços anexa à lei complementar, embora comportem interpretação ampla os seus tópicos. Cuida-se, no caso, da lista anexa à Lei Complementar 56/87. II. - Precedentes do Supremo Tribunal Federal. III. - Ilegitimidade da exigência do ISS sobre serviços expressamente excluídos da lista anexa à Lei Complementar 56/87. IV. - RE conhecido e provido." (STF, RE nº 361829 / RJ, Relator Min. Carlos Velloso, Segunda Turma, julgado em 13/12/2005).

308 "Art. $3^{\circ}$ - O serviço considera-se prestado e o imposto devido no local do estabelecimento prestador ou, na falta do estabelecimento, no local do domicílio do prestador, exceto nas hipóteses previstas nos incisos I a XXII, quando o imposto será devido no local:" 
E, por assim dizer, a inovação constante da LC $\mathrm{n}^{\circ} 116 / 03$ admite a extraterritorialidade $^{309}$ das leis municipais, alcançando, inclusive, o serviço prestado integralmente no exterior, em detrimento do princípio da territorialidade das normas que guarda relação com o aspecto espacial da regra-matriz de incidência tributária.

Em verdade, não apenas o serviço realizado parcialmente no território nacional, mas também o serviço integralmente executado no exterior e contratado por tomador aqui domiciliado é passível de tributação. Entretanto, tal inovação legal é de duvidosa constitucionalidade. ${ }^{310}$

Há quem defenda ${ }^{311}$ que a inovação decorre do fato de o Brasil ter adotado o princípio do destino para reger o seu comércio internacional, segundo o qual as exportações não são tributadas, mas as importações o são, em detrimento do princípio da origem, pelo qual as exportações são tributadas e as importações não o são. Trata-se de entendimento controvertido.

Posta de lado a celeuma sobre o tema, dado que será abordada em momento apropriado, há que se recordar que a partir da Emenda Constitucional no 3/93, que alterou o art. 156, II, $\$ 3^{\mathrm{o} 312}$, as exportações de serviços para o exterior passaram a poder ser excluídas da incidência do ISS, o que indica que o Brasil pode ter adotado o princípio do destino para regular o comércio internacional.

${ }^{309}$ Tal extraterritorialidade não está em consonância com o art. 102, do CTN, já que só é admissível se prevista em convênios e para que produza efeitos dentro do Brasil.

310 Cf. ALVES, Anna Emilia Cordelli, ISS - Aspectos Relevantes Decorrentes da Análise do Artigo $1^{\circ}$ da Lei Complementar $n^{\circ} 116$, de 31 de julho de 2003. Revista Dialética de Direito Tributário, $n^{\circ}$ 99, São Paulo: Dialética, p. 29.

${ }^{311}$ Luís Eduardo Schoueri, em artigo intitulado ISS sobre a Importação de Serviços do Exterior, defende a constitucionalidade da incidência do ISS sobre serviços provenientes do exterior ou que lá a respectiva prestação tenha sido iniciada (Revista Dialética de Direito Tributário, n ${ }^{\circ}$ 100, São Paulo: Dialética, 2004).

312 " $\S 3^{\circ}$ Em relação ao imposto previsto no inciso III do caput deste artigo, cabe à lei complementar:

I - fixar as suas alíquotas máximas e mínimas;

II - excluir da sua incidência exportações de serviços para o exterior;

III - regular a forma e as condições como isenções, incentivos e benefícios fiscais serão concedidos e revogados." 
Assim, em cumprimento ao comando constitucional, o art. $2^{\circ}$, I, da $\operatorname{LC} \mathrm{n}^{\mathrm{o}} 116 / 03^{313}$, estabelece que os serviços exportados (concluídos no exterior) não serão tributados pelo ISS.

Tal qual já mencionado, o art. $5^{\circ}$ da $\operatorname{LC~} n^{\circ} 116 / 03^{314}$ prevê que o contribuinte do imposto é o prestador do serviço e a lei permite que seja atribuída à terceira pessoa a responsabilidade pelo recolhimento do imposto que, em se tratando de importação de serviço, será o tomador ou o intermediário do serviço proveniente do exterior ou cuja prestação se tenha iniciado no exterior, consoante previsto no $\S 2^{\circ}$, do art. $6^{\circ}$, da lei.

O dever de pagar o ISS em razão da responsabilidade tributária determinada pela LC $n^{\circ} 116 / 03$ denota o caráter extraterritorial das leis municipais instituidoras do gravame sobre a importação de serviços e autoriza a tributação de contribuinte não residente no Brasil.

Ao tratar do ICMS supostamente incidente sobre as transações envolvendo a "aquisição" de software "de prateleira", que não passa da obtenção de uma licença de uso, constatamos a sua não incidência em razão da ausência de subsunção do fato concreto aos fatos descritos na hipótese de incidência tributária (notadamente no que tange ao critério material).

Resta saber se a concessão de licença de uso de software elaborado sob encomenda ou adaptável às necessidades do cliente se subsume ao previsto na regra-matriz de incidência tributária do ISS, assim exposta: Hipótese: a) critério material - prestar serviços de qualquer natureza, excetuando-se os serviços de transporte interestadual e intermunicipal e de comunicação; b) critério espacial - qualquer lugar do território do

313 "Art. $2^{\circ} \mathrm{O}$ imposto não incide sobre:

I - as exportações de serviços para o exterior do País; (...)"

314 "Art. $5^{\circ}$ Contribuinte é o prestador do serviço.

Art. $6^{\circ}$ Os Municípios e o Distrito Federal, mediante lei, poderão atribuir de modo expresso a responsabilidade pelo crédito tributário a terceira pessoa, vinculada ao fato gerador da respectiva obrigação, excluindo a responsabilidade do contribuinte ou atribuindo-a a este em caráter supletivo do cumprimento total ou parcial da referida obrigação, inclusive no que se refere à multa e aos acréscimos legais.

$\S 1^{\circ}$ Os responsáveis a que se refere este artigo estão obrigados ao recolhimento integral do imposto devido, multa e acréscimos legais, independentemente de ter sido efetuada sua retenção na fonte.

$\S 2^{\circ}$ Sem prejuízo do disposto no caput e no $\S 1^{\circ}$ deste artigo, são responsáveis:

I - o tomador ou intermediário de serviço proveniente do exterior do País ou cuja prestação se tenha iniciado no exterior do País (...)." 
Município ou do Distrito Federal (que tenha editado a lei instituidora do imposto) onde esteja localizado o estabelecimento prestador ou onde o serviço tenha sido executado (casos expressamente previstos na lei); c) critério temporal - data em que se considerem prestados os serviços; Consequente: d) critério pessoal - sujeito ativo é o Município ou o Distrito Federal e sujeito passivo é a pessoa física ou jurídica que presta os serviços; e) critério quantitativo - base de cálculo é o preço da prestação de serviços e a alíquota é um percentual (que pode variar de $2 \%$ a $5 \%$ ) sobre a base de cálculo nos termos definidos pela lei.

No que tange ao ISS incidente sobre a importação de serviços, a sua regra-matriz de incidência tributária nos termos da $\operatorname{LC} n^{\circ} 116 / 03$ pode ser assim resumida: Hipótese: a) critério material - "tomar" serviços provenientes do exterior ou cuja prestação tenha iniciado no exterior; b) critério espacial - qualquer lugar do território do Município ou do Distrito Federal onde esteja localizado o tomador dos serviços; c) critério temporal - data em que se considerem prestados os serviços; Consequente: d) critério pessoal - sujeito ativo é o Município ou o Distrito Federal e sujeito passivo é a pessoa física ou jurídica tomadora dos serviços ${ }^{315}$; e) critério quantitativo - base de cálculo é o preço da prestação de serviços e a alíquota é um percentual (que pode variar de $2 \%$ a $5 \%$ ) sobre a base de cálculo nos termos definidos pela lei.

\subsection{Princípio da autonomia municipal}

Segundo defende Aires F. Barreto ${ }^{316}$, "por autonomia municipal pode-se entender a faculdade conferida pela Constituição à pessoa política Município para editar - nos limites por ela traçados - suas próprias normas legislativas, dispor sobre o seu governo e organizar-se administrativamente.”

\footnotetext{
${ }^{315}$ Como bem observa o Professor Gerd Willi Rothmann, "o tomador do serviço transforma-se de contribuinte de fato em contribuinte de direito do ISS, visto que, além de ter a obrigação de recolhê-lo aos competentes cofres públicos municipais, é ele mesmo que suporta o ônus desse pagamento. Daí a impropriedade do $\S 2^{\circ}$, do Art. $6^{\circ}$, da Lei Complementar $n^{\circ} 116 / 03$, quando, no seu inciso I, erige o tomador ou intermediário do serviço importado em responsável pelo crédito tributário. (...) Acontece que o preço cobrado pelo residente no exterior não inclui o ISS a ser recolhido no Brasil, portanto o tomador não poderá retê-lo por ocasião do pagamento do preço. Neste caso, o ISS é obrigação própria do tomador que, na qualidade de substituto do contribuinte, paga o ISS, calculado sobre o preço do serviço importado." (Inconstitucionalidade múltipla na tributação da importação de serviços - Réquiem ou catarse do sistema tributário nacional?, Tese de livre-docência apresentada à Faculdade de Direito da Universidade de São Paulo, São Paulo, 2010, p. 86/87).

${ }^{316}$ ISS, op. cit., p. 9.
} 
A autonomia municipal é decorrência do pacto federativo ${ }^{317}$ que, nas palavras de Roque Antonio Carrazza ${ }^{318}$, constitui verdadeira coluna mestra do nosso sistema jurídico, pois convivem harmonicamente a ordem jurídica global (o Estado brasileiro) e as ordens jurídicas parciais, central (a União) e periféricas (os Estados-membros), sendo que a múltipla incidência só é possível por força da cuidadosa discriminação constitucional de competências tributárias.

Tal autonomia está baseada na liberdade dos munícipes elegerem o seu Prefeito e os vereadores que comporão o Poder Legislativo, a quem compete produzir leis próprias que versem sobre assuntos de interesse local (arts. 28 e 29, da Constituição).

Além da liberdade para se organizar, para legislar e para se auto-administrar, os Municípios detêm autonomia financeira ante a parcela de competência tributária que lhes foi conferida pela Magna Carta (art. 30).

De acordo com os ensinamentos de José Afonso da $\mathrm{Silva}^{319}$, a autonomia municipal está baseada em quatro capacidades: a) capacidade de auto-organização (elaboração de lei orgânica própria); b) capacidade de autogoverno (em razão da eleição dos Prefeitos e dos vereadores que comporão o Poder Legislativo, as Câmaras Municipais); c) capacidade normativa própria (pela competência de legislar sobre assuntos de sua competência exclusiva e suplementar); e d) capacidade de auto-administração (administração própria para manter e prestar os serviços de interesse local).

Aires F. Barreto ${ }^{320}$ defende a primazia da autonomia municipal por ser princípio fundamental do nosso regime em razão da Federação ser a própria essência do sistema e que a intervenção federal é a resposta (das mais graves) àquele que viola o citado princípio, o que - a seu ver - revela a sua importância e a sua posição hierárquica.

\footnotetext{
317 A República Federativa do Brasil, formada pela união indissolúvel dos Estados e Municípios e do Distrito Federal, constitui-se em Estado Democrático de Direito (art. $1^{\circ}$, da Constituição). Entretanto, Carrazza elucida que "os Municípios não influem, nem muito menos decidem, no Estado Federal. (...) não participam da formação da vontade jurídica nacional. (...) não integram o Congresso, já que não possuem representantes nem no Senado (Caso dos Estados), nem na Câmara dos Deputados (Casa do Povo)" (Curso de Direito Constitucional Tributário, São Paulo: Malheiros, 2006, p. 161).

318 Curso, op. cit., p. 139.

319 Curso de Direito Constitucional Positivo, 34 ${ }^{\text {a }}$ Ed., São Paulo: Malheiros, 2011, p. 641.

${ }^{320}$ ISS, op. cit., p. 10.
} 
A despeito da importância do referido princípio, acreditamos que ele não é ilimitado, pelo contrário. Ante aos inúmeros outros princípios constitucionais, notadamente aqueles que consistem em limitações ao poder de tributar, o princípio da autonomia deve conviver em harmonia com os demais, o que pode representar a sua parcial mitigação. Nesse sentido, Humberto Ávila ensina que:

"O princípio federativo impõe a busca de um equilíbrio entre a uniformidade da
Federação e a diversidade dos entes federados, inclusive, e especialmente, no
que se refere à competência tributária. O ideal federativo consiste, precisamente,
no equilíbrio entre o todo e as partes que o compõem, isto é, na harmonia entre
os dois princípios: os princípios da autonomia e da uniformidade federativas:
'Nenhum deles pode estar ausente, nem pode estar presente em demasia: de
um lado, não há federação se não houver, ao mesmo tempo, autonomia e
uniformidade; de outro, não há uniformidade se houver autonomia absoluta,
ao mesmo tempo em que não há autonomia se houver uniformização
absoluta.'(...)"321

As infindáveis discussões sobre a função da lei complementar em matéria tributária são exemplos sobre a limitação do princípio da autonomia municipal, dado que os ditames gerais do imposto são conferidos pela $\operatorname{LC} n^{\circ} 116 / 03$. $^{322}$

O princípio em análise, ao menos em tese, garante a cada Município e ao Distrito Federal a liberdade na escolha dos serviços tributáveis, contudo, ao se entender - como quer o art. 146, da Constituição - que a lei complementar evite conflitos de competência impondo normas gerais em matéria tributária, a relação dos serviços tributáveis é facilmente admitida como taxativa (numerus clausus) e limitadora da autonomia municipal.

O mesmo pode ser dito em relação à solução eleita pela lei complementar para evitar a bitributação ao determinar que o serviço considera-se prestado no local do estabelecimento prestador mesmo que executado em outro Município (salvo nos casos excepcionais expressamente previstos).

\footnotetext{
${ }^{321}$ Imposto sobre a Prestação de Serviços de Qualquer Natureza - Exportação de Serviços - Lei Complementar no 116/03 - Isenção: Requisitos e Alcance - Conceito de "Desenvolvimento" de Serviço e "Verificação" do seu Resultado, Revista Dialética de Direito Tributário, n 134, São Paulo: Dialética, 2006, p. 102.

${ }^{322}$ Em que pese já exista posicionamento jurisprudencial dominante.
} 
A competência tributária de cada Município limita-se aos fatos - assim entendidos os serviços previstos expressamente na $\operatorname{LC~}^{\circ}$ 116/03, bem como na lei local - ocorridos no seu território, sob pena de invasão na competência alheia (art. 30, da Constituição ${ }^{323}$ ).

Não obstante isso, há quem defenda o contrário. Em nome do princípio da autonomia municipal, Clélio Chiesa ${ }^{324}$ entende que os Municípios podem instituir o ISS sobre toda e qualquer prestação de serviço, exceto as que a Constituição afastou de sua competência, independentemente de estarem ou não previstas na lista de serviços veiculada por lei complementar.

Todavia, não podemos concordar com o doutrinador, pois se assim fosse, ou seja, se a autonomia municipal fosse irrestrita, a própria Constituição não teria delegado à lei complementar o dever de "definir" os serviços tributáveis, tão pouco teria delegado o dever de fixar as alíquotas mínimas e máximas do ISS.

Admitir uma autonomia municipal absoluta representa diminuir a função da lei complementar em matéria tributária (consoante será visto adiante), bem como vilipendiar os demais preceitos constitucionais que devem conviver em harmonia.

\subsection{Princípio da territorialidade}

$\mathrm{O}$ art. 102, do CTN determina que a legislação tributária dos Estados, do Distrito Federal e dos Municípios vigoram no País, fora dos respectivos territórios, nos limites em que the reconheçam extraterritorialidade os convênios de que participem, ou do que disponham esta ou outras leis de normas gerais expedidas pela União.

323 “Art. 30. Compete aos Municípios: I - legislar sobre assuntos de interesse local; II - suplementar a legislação federal e a estadual no que couber; III - instituir e arrecadar os tributos de sua competência, bem como aplicar suas rendas, sem prejuízo da obrigatoriedade de prestar contas e publicar balancetes nos prazos fixados em lei; IV - criar, organizar e suprimir distritos, observada a legislação estadual; V organizar e prestar, diretamente ou sob regime de concessão ou permissão, os serviços públicos de interesse local, incluído o de transporte coletivo, que tem caráter essencial; VI - manter, com a cooperação técnica e financeira da União e do Estado, programas de educação infantil e de ensino fundamental; VII - prestar, com a cooperação técnica e financeira da União e do Estado, serviços de atendimento à saúde da população; VIII - promover, no que couber, adequado ordenamento territorial, mediante planejamento e controle do uso, do parcelamento e da ocupação do solo urbano; IX - promover a proteção do patrimônio histórico-cultural local, observada a legislação e a ação fiscalizadora federal e estadual."

324 Competência para tributar as operações com programas de computador (softwares), Campos, Djalma de (coord.), Revista Tributária e de Finanças Públicas, vol. 36, São Paulo: RT, 2001, p. 44. 
O referido dispositivo prevê a extraterritorialidade como regra de exceção, tornando o princípio da territorialidade verdadeiro limite a ser observado pelos entes da federação para que não invadam a competência tributária alheia.

A bem da verdade, o princípio da territorialidade em matéria tributária não está expressamente previsto na Constituição Federal, mas decorre do próprio pacto federativo e é essencial para a concretização da repartição de competências tributárias.

A territorialidade da lei tributária guarda relação direta com as noções de território e base física sobre a qual o ente político exerce soberania fiscal. Contudo, nem todos os fatos ocorridos no seu território podem ser alcançados por suas leis, ante a estrita repartição de competências tributárias constitucionalmente previstas.

O referido princípio adotado na sua mais genuína acepção é tido como a força de atração exercida pela lei de determinado ente político sobre os fatos jurídicos tributários que ocorrem nos limites geográficos do seu território.

Para Aires F. Barreto ${ }^{325}$ a Constituição proíbe a extraterritorialidade da lei (salvo nos casos expressamente previstos) e impõe o princípio da territorialidade como regra, de modo que a jurisdição dos entes políticos circunscreve-se aos seus limites territoriais, o que equivale a dizer que fora deles suas leis não têm aptidão para produzir efeitos, não têm eficácia jurídica, motivo pelo qual os fatos ocorridos em território alheio não podem ser alcançados pela lei fiscal de determinado ente político.

Em outras palavras, a territorialidade em matéria tributária se perfaz de acordo com o aspecto espacial da regra-matriz de incidência tributária, que vinculado à materialidade ocorrida nos limites do território do ente tributante (e autor da referida lei) autoriza a produção de norma individual e concreta que ensejará repercussões fiscais.

Não obstante isso, há quem compreenda o princípio da territorialidade de forma mais ampla. Alfredo Augusto Becker ${ }^{326}$, por exemplo, reconhece que o mencionado

\footnotetext{
${ }^{325}$ ISS - Não incidência sobre atividades desenvolvidas em águas marítimas, Revista Dialética de Direito Tributário, ${ }^{\circ}$ 200, São Paulo: Dialética, 2012, p. 7.

${ }^{326}$ Teoria Geral do Direito Tributário, São Paulo: Noeses, 2007, p. 299.
} 
princípio pode ser explicado como sendo a eficácia jurídica da lei tributária dentro do território do ente que a editou, mas pondera que a "criação dos mercados comuns e das zonas de livre comércio; a tributação de bens existentes no estrangeiro pelo imposto de transmissão causa mortis; os problemas, no plano internacional, da dupla imposição pelo imposto de renda, despertaram a atenção dos modernos doutrinadores para a falsa 'obviedade' do fundamento da territorialidade da lei tributária."

Seria dizer que o dinamismo dos fatos sociais e, consequentemente, do direito tributário, fazem com que o princípio da territorialidade ganhe novos contornos e reflexões.

E, por assim dizer, a LC $n^{\circ} 116 / 03$ elegeu, como regra geral, o estabelecimento prestador como elemento de conexão com a lei que terá eficácia sobre os serviços prestados por aquele estabelecimento (ainda que executados em outro Município), de modo que o serviço será considerado prestado e o imposto devido ao Município onde estiver localizado o dito estabelecimento prestador. ${ }^{327}$

Para justificar a sua concordância com a previsão legal supramencionada, Alberto Macedo $^{328}$ admite a extraterritorialidade material da lei e rechaça a formal.

Para ele, determinado ente político pode prescrever comandos normativos que se refiram a eventos ocorridos no território alienígena (extraterritorialidade material), mas não pode produzir normas que autorizem as suas autoridades a praticarem atos de coerção no território de outros entes políticos (extraterritorialidade formal ${ }^{329}$ ).

\footnotetext{
${ }^{327}$ Neste sentido, cite-se a ementa do seguinte julgado: "TRIBUTÁRIO. ISS. LEI COMPLEMENTAR 116/2003. SERVIÇO DE INFORMÁTICA.COMPETÊNCIA PARA SUA COBRANÇA. FATO GERADOR. LOCAL DO ESTABELECIMENTO DO PRESTADOR.

1. A Primeira Seção do Superior Tribunal de Justiça, ao julgar o REsp 1.117.121/SP, Min. Eliana Calmon, DJe de 29.10.2009, sob o regime do art. 543-C do CPC, reafirmou o entendimento segundo o qual, na ocorrência do fato gerador sob a égide da LC 116/2003, à exceção de serviços de construção civil, o ISSQN é devido ao Município do local da sede do prestador de serviço.

2. In casu, verifica-se que a prestação de serviços de informática (comércio de produtos novos e usados e locação de equipamentos de informática) é o fato gerador, ocorrido sob a égide da Lei Complementar 116/2003, que passou a competência para o local da sede do prestador do serviço.

3. Agravo Regimental não provido." (STJ, AgRg no REsp n ${ }^{\circ}$ 1.280.592/MG, Relator Ministro Herman Benjamin, DJ 01.03.2012).

328 O critério, op. cit., p. 312.

${ }^{329}$ A tal título, cite-se: "TRIBUTÁRIO. FISCALIZAÇÃO MUNICIPAL. APRESENTAÇÃO DE LIVROS E DOCUMENTOS FISCAIS. ESTABELECIMENTOS SITUADOS EM OUTROS MUNICÍPIOS.

1. A fiscalização municipal deve restringir-se à sua área de competência e jurisdição.
} 
E, por assim dizer, o pesquisador acredita que o princípio da (extra)territorialidade (formal) impõe limites na adoção dos elementos de conexão, "na medida em que, apesar de a lei de norma geral poder prescrever normas jurídicas sobre critérios externos à territorialidade do Município, tal possibilidade só possui efetividade se conectadas a esses critérios externos estejam situações que permitam ao Município efetivar sua atividade de fiscalização, cobrança e constituição do crédito tributário correspondente, como os estabelecimentos prestadores, por caracterizarem-se estes como elementos fixos, em que é possível ser exercida a eficácia da norma jurídica tributária, por parte das autoridades tributárias, na sua atividade de fiscalização, constituição e cobrança do crédito tributário." 330

Em detrimento do posicionamento acima, é importante ressaltar que desde a década de 90, o STJ prestigia o princípio da territorialidade da lei em matéria de ISS. Em diversos $\operatorname{casos}^{331}$ a Corte decidiu que a lei municipal não pode ser dotada de extraterritorialidade, de modo a irradiar efeitos sobre um fato ocorrido no território de outro Município:

"TRIBUTÁRIO. ISS. SUA EXIGÊNCIA PELO MUNICÍPIO EM CUJO TERRITÓRIO SE VERIFICOU O FATO GERADOR. INTERPRETAÇÃO DO ART. 12 DO DECRETO-LEI N. 406/68.

Embora a lei considere local da prestação de serviço, o do estabelecimento prestador (art. 12 do decreto-lei n. 406/68), ela pretende que o ISS pertença ao município em cujo território se realizou o fato gerador.

É o local da prestação do serviço que indica o município competente para a imposição do tributo (ISS), para que se não vulnere o principio constitucional implícito que atribui aquele (município) o poder de tributar as prestações em seu território.

A lei municipal não pode ser dotada de extraterritorialidade, de modo a irradiar efeitos sobre um fato ocorrido no território de município onde não se pode ter voga.

Recurso a que se nega provimento, indiscrepantemente." (STJ, $1^{\text {a }}$ Turma, RESP $\mathrm{n}^{\circ}$ 54.002/PE, Ministro Relator Demócrito Reinaldo, DJ 05/04/1995)

Em sendo o ISS um imposto sobre o consumo, parece-nos coerente que o dever de pagá-lo seja decorrente de uma relação jurídico-tributária estabelecida entre o prestador do

2. Ao permitir que o Município de São Paulo exija a apresentação de livros fiscais e documentos de estabelecimentos situados em outros municípios, estar-se-ía concedendo poderes à municipalidade de fiscalizar fatos ocorridos no território de outros entes federados, inviabilizando, inclusive, que estes exerçam o seu direito de examinar referida documentação de seus próprios contribuintes.

3. Recurso parcialmente conhecido e não provido." (STJ, RESP $\mathrm{n}^{\circ}$ 73.086/SP Ministro Relator João Otávio de Noronha, DJ: 30.06.2003).

330 O critério, op. cit., p. 312/313.

331 Vide os seguintes acórdãos proferidos sob a vigência o DL no 406/68: RESP no 41.867-4/RS, RESP $n^{\circ}$ 54.002-0/PE, RESP $n^{\circ} 115.338 / E S$, ERESP $n^{\circ} 168.023 /$ CE e Embargos de Divergência em RESP $n^{\circ}$ 130.792/CE. 
serviço e o Município que - a nosso ver - deveria ser o do local onde o serviço é executado, tido como "consumido" (muito embora a LC n ${ }^{\circ} 116$ continue determinando que o imposto é devido ao Município do local do estabelecimento prestador).

Aliás, no que tange à tributação do comércio internacional de serviços, há uma candente e renomada doutrina, representada por Gerd Willi Rothmann, Luís Eduardo Schoueri e Alberto Macedo, que defende que o Brasil teria adotado o princípio do destino para as situações de exportação/importação de mercadorias e serviços, em detrimento do princípio da origem.

De acordo com o princípio do destino, as exportações não são tributadas (para serem tributadas no destino/exterior), enquanto as importações o são, ao passo que pelo princípio da origem, as exportações são tributadas (no local da produção das mercadorias e serviços) e as importações não o são. ${ }^{332}$

Na sua brilhante tese de livre-docência apresentada à Faculdade de Direito da Universidade de São Paulo, ao tratar do princípio da territorialidade, o Professor Gerd Willi Rothmann faz uma crítica aos que não levam em consideração a natureza econômica do fato tributável e aduz que o princípio do destino é o que guarda mais coerência com os impostos que gravam o consumo como, por exemplo, o IPI, o ICMS e o ISS. Segundo ele:

\footnotetext{
"Quanto aos impostos indiretos sobre circulação ou consumo de mercadorias e serviços, o Brasil adota o princípio universalmente reconhecido, que atribui a competência tributária ao país do destino e não ao país de origem do bem ou do serviço, visto que é lá que se encontra o contribuinte de fato desses impostos, ou seja, o consumidor final. Portanto, a receita fiscal dos impostos que gravam o consumo deve caber ao Brasil, onde reside o consumidor das mercadorias ou o tomador dos serviços.

Pelo mesmo princípio do destino, acolhido pela Constituição Federal, o Brasil garante a neutralidade fiscal, não onerando a exportação de bens e serviços pelo ICMS ou pelo ISS.",333
}

Certamente há diversos dispositivos constitucionais ${ }^{334}$ que denotam a desoneração de exportações e a taxação das importações. Contudo, não acreditamos que o princípio do

332 MACEDO, Alberto, ISS e PIS-COFINS-Importação - Critérios Espacial e Pessoal na Prestação Internacional de Serviços, Revista Dialética de Direito Tributário, nº 187, São Paulo: Dialética, 2011, p. 10 .

333 Inconstitucionalidade múltipla na tributação da importação de serviços - Réquiem ou catarse do sistema tributário nacional?, Tese de livre-docência apresentada à Faculdade de Direito da Universidade de São Paulo, 2010, p. 73/75. 
destino possa ser aplicado indistintamente aos tributos comumente incidentes no comércio internacional de bens e de serviços sem antes verificar se os respectivos arquétipos constitucionais dão guarida à sua aplicação. ${ }^{335}$

A adoção do princípio do destino pode não guardar harmonia com o princípio da territorialidade, por exemplo, já que respaldaria a tributação da prestação de serviço ocorrida fora dos territórios dos Municípios brasileiros.

Neste aspecto, acompanhamos a posição de Heleno Taveria Tôrres ${ }^{336}$ baseado no alcance espacial das normas tributárias sobre os fatos juridicizados pelo ordenamento, que estabelece uma reserva de exclusividade para a aplicação das leis dos Municípios aos fatos ocorridos nos seus respectivos territórios, mediante uma conexão material (presença da prestação de serviços), promovidos por residentes ou não residentes.

\subsection{Lei complementar em matéria tributária}

Consoante determina o art. 146, da Constituição Federal:

\footnotetext{
“Art. 146. Cabe à lei complementar:

I - dispor sobre conflitos de competência, em matéria tributária, entre a União, os Estados, o Distrito Federal e os Municípios;

II - regular as limitações constitucionais ao poder de tributar;

III - estabelecer normas gerais em matéria de legislação tributária, especialmente sobre:

a) definição de tributos e de suas espécies, bem como, em relação aos impostos discriminados nesta Constituição, a dos respectivos fatos geradores, bases de cálculo e contribuintes;

b) obrigação, lançamento, crédito, prescrição e decadência tributários;

c) adequado tratamento tributário ao ato cooperativo praticado pelas sociedades cooperativas;

d) definição de tratamento diferenciado e favorecido para as microempresas e para as empresas de pequeno porte, inclusive regimes especiais ou simplificados no caso do imposto previsto no art. 155, II, das contribuições previstas no art. 195 , I e $\S \S 12$ e 13, e da contribuição a que se refere o art. 239.

Parágrafo único. A lei complementar de que trata o inciso III, d, também poderá instituir um regime único de arrecadação dos impostos e contribuições da União, dos Estados, do Distrito Federal e dos Municípios, observado que:
}

334 Art. 149, §2 , I e II e Art. 195, IV.

335 Se é verdade que o Brasil adotou o princípio do destino no comércio internacional de bens e serviços, notadamente em relação aos tributos que gravam o consumo, por qual razão o IRRF não incide sobre os rendimentos enviados ao exterior para pagar por importações de mercadorias destinadas à revenda, enquanto os rendimentos enviados ao exterior para pagar pela importação de serviços sofrem a incidência do imposto de renda?

336 Prestações de serviços provenientes do exterior ou cuja prestação se tenha iniciado no exterior, in Imposto sobre Serviços - ISS na Lei Complementar no 116/03 e na Constituição, São Paulo: Manole, 2004, p. 286. 
I - será opcional para o contribuinte;

II - poderão ser estabelecidas condições de enquadramento diferenciadas por Estado;

III - o recolhimento será unificado e centralizado e a distribuição da parcela de recursos pertencentes aos respectivos entes federados será imediata, vedada qualquer retenção ou condicionamento;

IV - a arrecadação, a fiscalização e a cobrança poderão ser compartilhadas pelos entes federados, adotado cadastro nacional único de contribuintes."

A Constituição ainda determina que é por meio da lei complementar, instrumento normativo que requer maioria absoluta para a sua aprovação (art. 69), que são instituídas as contribuições sociais previstas no art. $195, \S 4^{\circ}$, os impostos de competência residual da União (art. 154, I), os empréstimos compulsórios (art. 148), o ITCMD (art. 155, §1 ${ }^{\circ}$, III),

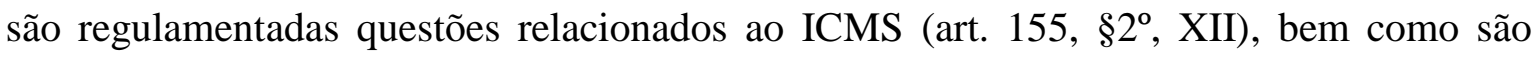
definidos os serviços passíveis de tributação pelos Municípios, são definidas as alíquotas máximas e mínimas do ISS, são excluídos da incidência do gravame municipal a exportação de serviços e são reguladas as isenções, incentivos e benefícios fiscais (art. 156, $\S 3^{\circ}$, I, II e III).

Alberto Macedo ${ }^{337}$ bem observa que no atual ordenamento jurídico brasileiro, o Estado Federal (República Federativa do Brasil) apresenta complexa estrutura formada por: (i) ordens jurídicas parciais (ordem jurídica federal-União; ordem jurídica estadual e distrital; e, ordem jurídica municipal); e (ii) ordem jurídica total, que é a reunião das três ordens jurídicas parciais.

Celso Ribeiro Bastos ${ }^{338}$ ensina que de acordo com as competências legislativas, a lei complementar pode se revestir do caráter federal (quando instrumento da União) e somente produz efeitos e abrange a União, ou do caráter nacional (quando instrumento do Estado Federal) que produz efeitos sobre todos os entes federados.

A lei complementar tributária prevista no art. 146, da Constituição reveste-se do caráter de lei nacional, que vincula todos os entes da federação. A LC n ${ }^{\circ}$ 116/03 possui como fundamento de validade justamente o citado artigo, bem como o art. 156.

\footnotetext{
337 O critério op. cit., p. 300.

338 Apud MACEDO, Alberto, O critério, op. cit., p. 300.
} 
Não vamos esmiuçar aqui as diferenças entre as teorias doutrinárias denominadas de dicotômica ${ }^{339}$ e tricotômica sobre a lei complementar em matéria tributária, pois além de serem irrelevantes para o presente trabalho, acreditamos que a teoria tricotômica é a que mais se aproxima dos ditames previstos na Constituição.

A teoria tricotômica, defendida por diversos doutrinadores ${ }^{340}$, reconhece que as atribuições da lei complementar são as que estão previstas nos incisos do art. 146, supratranscrito e, a nosso ver, não há como ignorar a vontade do legislador constituinte.

Em face da diversidade de ordens jurídicas no ordenamento, o pacto federativo busca justamente a harmonia dos entes federados, o que é concretizada por meio da lei complementar que estabeleça normas gerais em matéria tributária, impondo limitações constitucionais ao poder de tributária e regramentos com vistas a evitar e dirimir conflitos de competência.

Há quem possa pensar que a LC no 116/03 é inconstitucional por afrontar a autonomia municipal, já que limitaria a competência tributária dos Municípios e do Distrito Federal por não trazer uma definição dos serviços tributáveis, mas uma lista taxativa sem conceder liberdade para novas inclusões, além de determinar onde o serviço é considerado prestado e a quem é devido o imposto.

Temos para nós que ao determinar a base de cálculo, o fato gerador e o contribuinte do ISS, por exemplo, a LC n ${ }^{\circ} 116 / 03$ está exercendo a aptidão que lhe foi dada pela alínea "a", do inciso III, do art. 146, da Constituição, bem como está prevenindo conflitos de competência, notadamente quanto à lista dos serviços tributáveis (hipótese de incidência critério material), quanto à definição do contribuinte (critério pessoal) e quanto ao local onde o serviço é considerado prestado (critério espacial), além de impor limitações ao poder de tributar ${ }^{341}$ no tocante a não incidência do imposto sobre a exportação de serviços $\left(\operatorname{art} .2^{\mathbf{o}}\right)$.

339 Geraldo Ataliba, Paulo de Barros Carvalho e Roque Antonio Carrazza, por exemplo, defendem esta teoria por acreditarem, de modo geral, que a finalidade da lei complementar é apenas dispor sobre conflito de competência e regular limitações ao poder de tributar.

340 Por exemplo: Luciano Amaro, Hamilton Dias de Souza e Marco Aurélio Greco.

341 Humberto Ávila acredita que "ao estabelecer isenção geral para as exportações de serviços para o exterior do País, o legislador complementar realizou aquela finalidade, constitucionalmente estabelecida, de fomentar a vinculação dos entes federados com os compromissos da unidade da Federação no tocante às 
Notadamente em relação ao contribuinte e a quem é devido o imposto, a LC n ${ }^{\circ}$ 116/03 visa a impedir eventuais conflitos de competência tributária que poderiam existir entre Municípios. Imagine-se, apenas por hipótese, se cada Município pudesse determinar quem seria o contribuinte, se o prestador ou o tomador dos serviços, por exemplo. Neste caso, poderia haver "dois" contribuintes em uma única prestação de serviço, o prestador, assim determinado por um dos Municípios e o tomador, eleito pelo outro.

A LC também objetiva evitar conflitos entre Estados e Municípios no tocante à prestação de serviços acompanhados de mercadorias, que incluídos na lista anexa à lei, ficam sujeitos ao ISS.

Além disso, o art. 156, III, da Constituição expressamente determina que o imposto municipal incide sobre serviços de qualquer natureza definidos em lei complementar. A mencionada lei não apenas está autorizada a indicar os serviços tributáveis (os quais devem estar em consonância com a Constituição, sob pena de inconstitucionalidade, consoante será visto mais adiante), mas também a determinar o fato gerador do imposto.

Por conta disso, o núcleo da hipótese de incidência do ISS está na conjugação do verbo prestar acompanhado do complemento serviços de qualquer natureza.

De um modo geral, a LC n 116/03 traz não apenas a lista dos serviços tributáveis, mas toda a conformação da regra-matriz de incidência tributária, o que - a nosso ver - não constitui ofensa à autonomia municipal, mas a via adequada para preservar o pacto federativo, para dispor sobre conflitos de competência (objetivando evitá-los), para dispor sobre normas gerais em matéria tributária e impor limitações ao poder de tributar, o que não quer dizer que as suas disposições sejam eficazes o bastante ou que todas as disposições da lei estejam em conformidade com a Constituição ou que não possam ser declaradas inconstitucionais.

relações internacionais. E o fez delimitando, num degrau maior de concretização, o âmbito de competência municipal por meio do estabelecimento de uma isenção de caráter nacional. O resultado disso é a ausência de competência dos municípios para tributar a exportação de serviços para o exterior." (Imposto sobre a Prestação de Serviços de Qualquer Natureza - Exportação de Serviços - Lei Complementar $n^{\circ}$ 116/03 - Isenção: Requisitos e Alcance - Conceito de "Desenvolvimento" de Serviço e "Verificação" do seu Resultado. Revista Dialética de Direito Tributário, no 134, São Paulo: Dialética, 2006, p. 102). 


\subsection{Critério material: Prestar serviços de qualquer natureza}

Nos termos do art. 156, III, da Constituição Federal e da LC nº 116/03, o ISS incide sobre a prestação de serviços de qualquer natureza.

Consoante ensina Aires F. Barreto ${ }^{342}$, “a Constituição não define serviços, para efeitos tributários. Pelo menos não o faz explicitamente. Limita-se a fazer referência à expressão 'serviço', como que relegando ao intérprete a tarefa de defini-lo. Não se entenda, entretanto, que o intérprete tem liberdade nesse mister. Pelo contrário, ele está condicionado por todo o contexto constitucional, pelas exigências dos princípios fundamentais e pelas insinuações sistemáticas, suficientemente vigorosas para balizá-los decisivamente."

Em outras palavras, muito embora não exista uma expressa definição constitucional dos serviços de qualquer natureza para fins de incidência do ISS, a partir da repartição das competências tributárias, das limitações constitucionais ao poder de tributar e dos princípios constitucionais, obtém-se - ainda que, por vezes, de modo implícito - a hipótese de incidência possível, a base de cálculo possível e a alíquota possível, etc., das várias espécies e subespécies de tributos ${ }^{343}$.

E, por assim dizer, Humberto Ávila ${ }^{344}$ entende que quando a Constituição utiliza um termo sem conceituá-lo termina por incorporar o conceito que é utilizado no direito infraconstitucional pré-constitucional vigente antes da sua promulgação, motivo pelo qual as regras constitucionais atributivas de competência também o incorporam.

Seria dizer que os serviços de qualquer natureza devem ser compreendidos, não apenas com base nos princípios constitucionais, nas limitações constitucionais ao poder de tributar e na repartição de competências tributárias, mas também a partir dos conceitos de

${ }^{342}$ ISS, op. cit., p. 27.

${ }^{343}$ Cf. CARRAZZA, Roque Antonio, Curso, op. cit., p. 440.

${ }^{344}$ Imposto sobre serviços de qualquer natureza - ISS. Normas constitucionais aplicáveis. Precedentes do Supremo Tribunal Federal. Hipótese de Incidência, Base de Cálculo e Local da Prestação, Leasing Financeiro: Análise da Incidência, Revista Dialética de Direito Tributário, $\mathrm{n}^{\circ}$ 122, São Paulo: Dialética, 2005, p. 123. 
direito privado firmados até aquele momento histórico, sem que possam ser modificados pelo legislador infraconstitucional pós-constitucional ${ }^{345}$.

A respaldar o seu posicionamento, o mencionado Professor ${ }^{346}$ cita decisões que demonstram que o STF tende a decidir desta forma, ou seja, fazendo uso de conceitos constitucionais pressupostos (conceitos de direito infraconstitucional pré-constitucional), como, por exemplo: (i) ao julgar a instituição da contribuição social sobre o faturamento, a Corte decidiu que o conceito de faturamento seria o conceito de faturamento previsto no DL n ${ }^{\circ}$ 2.397/87, ou seja, a receita bruta proveniente da venda de mercadorias e da prestação de serviços (RE $\left.n^{\circ} 150.755 / \mathrm{PE}\right)$; (ii) ao analisar a incidência da contribuição social sobre a folha de salários sobre a remuneração pagas a administradores, avulsos e autônomos, o Tribunal decidiu que o conceito de salário seria aquele previsto na CLT que é a remuneração paga pelo empregador ao empregado, assim considerado aquele que mantém vínculo contínuo de subordinação com o seu empregador ( $\operatorname{RE~} n^{\circ}$ 166.772/RS); (iii) ao analisar a instituição do ICMS sobre a importação de mercadorias por pessoa física, o STF decidiu que o conceito de mercadoria seria aquele previsto no Código Comercial, ou seja, coisa móvel que possa ser objeto de comércio por quem exerce mercancia com habitualidade ( $\left.\operatorname{RE~n}^{\circ} 203.075-9\right)$.

Diante disso, acreditamos haver um conceito constitucional implícito para a expressão prestar serviços de qualquer natureza que deve ser respeitado pelo legislador ordinário, pela doutrina e pela jurisprudência.

Aires F. Barreto ${ }^{347}$ ensina que "serviço é a prestação de esforço humano a terceiros, com conteúdo econômico, em caráter negocial, sob regime de direito privado, tendente à obtenção de um bem material ou imaterial."

Bernardo Ribeiro de Moraes ${ }^{348}$ ensina que os serviços tributáveis pelo ISS são aqueles praticados por empresa ou profissional autônomo, que constituam fornecimento de trabalho realizado por uma pessoa em favor de outra, mediante remuneração, que não estejam na competência dos Estados e que constem da lista anexa à lei complementar.

\footnotetext{
345 Expressão cunhada por Humberto Ávila (Imposto, op. cit., p. 123).

${ }^{346}$ Cf. ÁVILA, Humberto, Imposto, op. cit., p. 121.

347 ISS, op. cit., p. 27.

348 Doutrina e Prática do ISS, São Paulo: RT, 1978, p. 84 e 92.
} 
O profissional autônomo deve ser assim entendido como uma pessoa física que presta serviços com habitualidade ${ }^{349}$ (continuidade e como uma profissão), sem subordinação jurídica ou dependência hierárquica (ou seja, com inteira liberdade de ação e sem que o tomador do serviço possa comandar ou dar ordens ao prestador) e mediante remuneração (a prestação de serviço há de ser onerosa). ${ }^{350} \mathrm{E}$, por assim dizer, os serviços prestados em decorrência da relação de emprego ou de vínculo estatutário estão fora do âmbito de incidência do ISS.

A empresa prestadora de serviço, por sua vez, é aquela caracterizada pela formação de uma unidade econômica organizada dedicada à prestação de serviços, desenvolvidos com habitualidade em favor de terceiros e com o objetivo de lucro.

Os serviços passíveis de tributação pelo ISS devem ser prestados sob o regime de direito privado, pois os serviços públicos não são alcançados pelo imposto já que a Constituição prevê a imunidade recíproca entre os entes políticos (art. 150, VI, “a”), o que constitui uma reiteração expressa da isonomia entre eles, além de constituir corolário do pacto federativo. ${ }^{351}$

O mesmo pode ser dito em relação aos serviços prestados por empresa pública ou por sociedade de economia mista que, a despeito de serem regidas pelo regime de direito privado, ao fazerem-nos na condição de concessionárias (quando a competência para prestação do serviço é de pessoa política diversa daquela que criou a executora do serviço) ou ao fazerem-nos por delegação (quando o serviço é próprio de entidade política que criou a empresa executora), os serviços seguem sendo públicos e, portanto, há imunidade. ${ }^{352}$

Tal entendimento encontra-se pacificado pela jurisprudência ${ }^{353}$ do STF, segundo a qual os serviços públicos de competência exclusiva de determinado ente político estão

\footnotetext{
349 Bernardo Ribeiro Moraes sustenta que "o ISS incide sobre pessoas que habitualmente prestam serviços a terceiros, seja de forma habitual ou ocasional em relação ao interessado no serviço. O advogado pode prestar serviço o ano todo para o seu cliente, ou prestá-lo uma única vez. Será alcançado pelo ISS, pois a habitualidade na sua profissão é inerente, desde que a exerça. É esta habitualidade no exercício profissional que trará status ao prestador do serviço" (Doutrina, op. cit., p. 121).

350 Cf. MORAES, Bernardo Ribeiro, Doutrina, op. cit., p. 94/95.

351 Cf. BARRETO, Aires F., ISS, op. cit., p. 78.

352 Cf. BARRETO, Aires F., ISS, op. cit., p. 54.

353 Ag.Reg.RE 552.736/RS, Ministra Relatora: Cármen Lúcia, DJ: 20.10.2009.
} 
albergados pela imunidade ainda que prestados por empresa pública e não constituem hipótese de incidência do ISS.

É importante ressaltar que o inciso II, do art. 145, da Constituição prevê a possibilidade de os entes políticos instituírem taxas sobre a utilização efetiva ou potencial de serviços públicos específicos e divisíveis, prestados ao contribuinte ou postos à sua disposição. Assim, o serviço público efetivo ou potencial, desde que específico e divisível, não é passível de ser tributado pelo ISS, mas pode constituir hipótese de incidência de taxa.

Nos termos do art. 150, VI, $\S 2^{\circ}$, da Constituição, as autarquias e as fundações instituídas pelo Poder Público fazem jus à imunidade de modo que também em relação a estas é vedado instituir ISS sobre os serviços vinculados às suas finalidades essenciais ou às delas decorrentes. 354

A mesma imunidade deve ser aplicada em relação a eventuais serviços prestados por templos de qualquer culto ${ }^{355}$ (art. 150, VI, “b”, da Constituição), por partidos políticos e suas fundações, pelas entidades sindicais de trabalhadores e pelas instituições de educação e de assistência social sem fins lucrativos (art. 150, VI, “c”, da Constituição). ${ }^{356}$

Feitas essas considerações em relação aos casos de imunidade, o esforço físico desenvolvido em favor de outrem deve denotar conteúdo econômico, o que é marcado pelo recebimento de remuneração ("preço do serviço"), pois a hipótese de incidência dos impostos é escolhida pelo legislador levando-se em consideração a sua natureza econômica, em razão da capacidade contributiva do cidadão, que deve ser observada quando da instituição do imposto. ${ }^{357}$

${ }^{354}$ Cf. BARRETO, Aires F., ISS, op. cit., p. 79.

355 Aires F. Barreto ressalta que "a imunidade do templo implica exoneração da entidade ao qual pertence, apenas e tão-só, do ISS que poderia incidir relativamente ao templo. Não se confunda essa imunidade com a das instituições de educação ou de assistência social. O fato de o templo ser imune ao ISS não implica, obrigatoriamente, imunidade da instituição religiosa que o mantenha. Embora o templo seja imune quanto ao ISS, pode a instituição ao qual ele pertença não merecer o beneplácito da imunidade em relação aos serviços que preste, bastando, para tanto, haja o descumprimento de um dos incisos do art. 14, do CTN" (ISS, op. cit., p. 80).

356 Para Aires F. Barreto, a despeito de a imunidade do livro, jornal, periódico e do papel destinado à sua impressão ser objetiva, tal desoneração deveria albergar os custos das empresas que os editam, o que equivale a dizer que também seriam imunes do ISS os serviços referentes à produção, elaboração, confecção, venda, publicidade, importação, exportação, distribuição (ISS, op. cit., p. 91).

357 Cf. MORAES, Bernardo Ribeiro, Doutrina, op. cit., p. 114. 
De acordo com o princípio constitucional da capacidade contributiva (art. $145, \S 1^{\circ}$ ), sempre que possível, os impostos terão caráter pessoal e serão graduados segundo a capacidade econômica do contribuinte, facultado à administração tributária, especialmente para conferir efetividade a esses objetivos, identificar, respeitados os direitos individuais e nos termos da lei, o patrimônio, os rendimentos e as atividades econômicas do contribuinte. Sendo assim, os signos presuntivos de riqueza, reveladores da capacidade contributiva do contribuinte, é que devem ser levados em consideração na definição das hipóteses de incidência tributária.

A necessária presença do conteúdo econômico, revelador de signos presuntivos de riqueza, afasta do conceito de serviços de qualquer natureza o trabalho realizado gratuitamente ou "para si próprio", pois a ausência de cunho econômico não guarda relação com a materialidade eleita pela Constituição. ${ }^{358}$

Embasado nos ensinamentos de Ruy Barbosa Nogueira, Heleno Taveira Tôrres relembra trecho da obra do mestre que demonstra o seu entendimento quanto à necessidade do caráter oneroso para a configuração da prestação de serviço e a impropriedade da pretensão do Fisco municipal exigir o ISS sobre atividades que a empresa presta para si mesma como acessório do desempenho de sua atividade principal:

\footnotetext{
"Isto significa que a atividade ou serviço descrito como fato gerador desse imposto é aquele que seja a finalidade em si ou essencial de prestação a terceiros e não apenas um acessório ou uma função exercida para a própria empresa contribuinte.

(...) Veja-se, por exemplo, que os fiscais fazem referência a serviços de datilografia, expediente, administração de bens quando nada disso é objeto social, prestação ou exploração desses serviços. Estes são serviços que a própria contribuinte executa para si mesma, como acessórios ao desempenho de suas funções.

Esses serviços são, na verdade, despesas e não receitas. (...)

Portanto, o que pode ser fato gerador do imposto sobre serviços, nos termos do art. $8^{\circ}$ do Dec.-lei 406, da jurisprudência, da doutrina e do direito comparado, é a prestação de serviço não a si próprio ou como acessório, mas a outrem mediante remuneração ou preço.(...)"359
}

A passagem supratranscrita nos autoriza sustentar que os serviços de qualquer natureza passíveis de tributação pelo ISS são apenas os prestados como atividade

${ }^{358}$ Cf. BARRETO, Aires F., ISS, op. cit., p. 298.

359 Apud TÔRRES, Heleno Taveira, Conceito de estabelecimento como critério de solução de conflitos no ISS, FISCOSOFT, http://www.fiscosoft.com.br/a/5tvd/conceito-de-estabelecimento-como-criterio-desolucao-de-conflitos-no-iss-heleno-taveira-torre, acessado em 09.07.2012. 
finalística do prestador. Em outras palavras, os serviços-meio, assim entendidos como as atividades intermediárias necessárias à consecução do serviço-fim, não são passíveis de incidência do ISS.

Ainda que as atividades intermediárias constem da lista anexa à LC 116/03, não podem ser consideradas de maneira isolada como se fossem serviços autônomos a serem tributados pelo ISS. Para que sejam tributadas necessitam ser desenvolvidas como atividade fim do prestador de serviços, ou seja, precisam constar do seu objeto social, constituir atividade negocial prestada em favor de terceiro e mediante remuneração.

Sobre a não incidência do ISS sobre as atividades intermediárias ou serviços-meio, enriquecedoras são as palavras de Aires F. Barreto ${ }^{360}$ para quem "tributável é o serviçofim, isto é, o esforço humano prestado a terceiros como fim ou objeto, não as suas etapas, passos ou tarefas intermediárias, necessárias à obtenção do fim. As etapas, passos, processos, tarefas, obras, são feitas, promovidas, realizadas 'para' o próprio prestador e não 'para terceiros', ainda que estes os aproveitem (já que, aproveitando-se do resultado final, beneficiam-se das condições que o tornaram possível)".

Não são raras as vezes que o esforço humano finalístico em favor de outrem somente é obtido mediante a congregação de atividades concretizadas em etapas prévias. Não obstante isso, para fins de incidência do ISS não se admite a decomposição do serviço-fim nas atividades-meio, sem as quais aquele não seria ofertado.

É importante consignar que o ISS não incide sobre a potencial prestação de serviços, pelo simples fato de não configurar a concretização do fato jurídico tributário. Neste aspecto, vale lembrar que o imposto não incide sobre o negócio jurídico firmado entre as partes (prestador e tomador de serviços), mas sobre o fato ocorrido no mundo fenomênico, de modo que a sua ausência não faz irromper a imediata e infalível incidência da norma.

Assim, mesmo diante de contrato cujo objeto seja uma prestação de serviços, enquanto não houver o efetivo esforço humano em favor da parte tomadora, não há que se

${ }^{360}$ Regime jurídico-tributário da chamada conectividade, Revista Dialética de Direito Tributário, $\mathrm{n}^{\circ}$ 160, São Paulo: Dialética, 2009, p. 136. 
falar na incidência do ISS. Segundo José Souto Maior Borges ${ }^{361}$, "se assim não fora, ficariam sem efeito prático todos os dispositivos constitucionais limitadores da competência tributária. Imagine-se o que sucederia se a União pudesse tributar a renda potencial, a produção potencial de produtos industrializados, a titularidade potencial da propriedade rural e, os Estados, a circulação potencial de mercadorias."

Ao atualizar a obra de Aliomar Baleeiro, Misabel Derzi resumiu de forma precisa os atributos que os serviços passíveis de tributação pelo ISS devem apresentar:

\begin{abstract}
"A doutrina e a jurisprudência extraem da Constituição as seguintes características da hipótese de incidência do tributo:

1 - A prestação de serviços configura uma utilidade material ou imaterial como execução de obrigação de fazer e não de dar coisa;

2 - Deve ser prestada a terceiro, excluindo-se os serviços que a pessoa executa em seu próprio benefício, como o transporte de mercadoria de um estabelecimento para outro da mesma pessoa;

3 - Executando sem vínculo de subordinação jurídica, mas em caráter independente, razão pela qual excluem-se os serviços prestados pelos empregados a seus empregadores e pelos servidores públicos;

4 - Deve ser habitual, não meramente eventual;

5 - Assim como ser objeto de circulação econômica, executado com objetivo de lucro, excluindo-se serviços gratuitos e de cortesia, beneficentes ou a preços baixos, como alimentação servida a empregados gratuitamente ou a preço de custo;

6 - Finalmente, o serviço deve ser prestado em regime de direito privado (por pessoa física ou jurídica, empresa pública ou sociedade de economia mista); se público, haverá imunidade, exceto para aquele serviço dado em concessão ou permissão a terceiros. ${ }^{362}$
\end{abstract}

Portanto, estão fora do alcance do ISS os serviços sem conteúdo econômico, os imunes por determinação constitucional, os "serviços-meio" (necessários para a consecução dos "serviços-fim") e os serviços prestados em decorrência da relação de emprego.

Para Bernardo Ribeiro de Moraes ${ }^{363}$, o conceito de serviços de qualquer natureza advém da economia e deve ser entendido como trabalho aplicado à produção de bens imateriais, os quais, uma vez integrantes do rol dos serviços tributáveis e excluídos os serviços de competência dos Estados, devem - indistintamente - ser tributados pelo ISS.

361 Inconstitucionalidade e ilegalidade da cobrança do ISS sobre contratos de assistência médico-hospitalar, Revista de Direito Tributário, $\mathrm{n}^{\circ}$ 38, São Paulo: RT p. 168.

362 Limitações Constitucionais ao Poder de Tributar, Rio de Janeiro: Forense, 2006, p. 491.

363 Consoante apregoa: "Devemos observar que a lei complementar pode colocar no rol dos serviços alcançados pelo ISS a venda de qualquer bem imaterial (serviço), pois todo resultado do trabalho não constituído em bem material será serviço.” (Doutrina, op. cit., p. 98/99 e 153). 
A corrente doutrinária que defende um conceito econômico de serviço acredita que só existem duas espécies de bens suscetíveis de utilidade econômica, quais sejam: os corpóreos, assim tidos como as mercadorias/produtos (que integram hipóteses de incidência de outros tributos diversos do ISS), e os incorpóreos, que constituem serviços indiscriminadamente, por exclusão, tributados pelos Municípios.

O conceito econômico de serviço encontra-se superado - ao menos na doutrina ${ }^{364}$ pois não basta tratar-se de bem incorpóreo com utilidade econômica, tão pouco compor a lista dos serviços passíveis de tributação e não estar no âmbito de competência dos Estados. O serviço tributável pelos Municípios deve configurar uma verdadeira obrigação de fazer.

\subsection{O conceito de serviço a partir do direito privado: uma obrigação de fazer}

Além das considerações postas no item anterior, que são de suma importância para a compreensão dos serviços de qualquer natureza, há, ainda, outro atributo sem o qual os tais serviços não encontram identidade com o critério material da regra-matriz de incidência tributária do ISS e que merece ser esmiuçado.

Já foi dito que por conta da privatividade e da exaustividade da outorga de competências tributárias conferidas pela Constituição Federal, os Municípios só podem exigir o ISS sobre as realidades fáticas que configurem serviços nos termos preconizados pela Carta Magna.

A inexistência de uma definição constitucional expressa de serviços de qualquer natureza para fins de incidência do ISS não significa dizer que existe ampla margem para inovar na interpretação.

O conceito constitucional de serviços de qualquer natureza está implícito e por isso é pressuposto. A sua extração se dá a partir dos conceitos e definições do direito privado, existentes ao tempo da promulgação da Constituição, bem como a partir dos princípios

$\overline{364}$ A decisão proferida pelo STF, em 02.12.2009, quando do julgamento do RE 592.905/SC, sobre a incidência do ISS sobre o leasing financeiro, reacendeu a discussão sobre o caráter econômico do serviço. 
constitucionais, da outorga de competências atribuídas a cada ente federado e das limitações constitucionais ao poder de tributar.

Nos termos do art. 110, do CTN, o legislador tributário não pode alterar a definição, o conteúdo e o alcance dos institutos, conceitos e formas de direito privado, utilizados, expressa ou implicitamente, pela Constituição Federal, pelas Constituições dos Estados, ou pelas Leis Orgânicas do Distrito Federal ou dos Municípios, para definir ou limitar competências tributárias, já previamente definidas pela Constituição Federal.

Sendo assim, há que se analisar a questão sob a ótica do direito civil. Tal qual o Código Civil de 1916, o modelo de 2002 continua prevendo que as obrigações se dividem em obrigações de dar, de fazer e de não fazer. A obrigação de fazer é a que interessa ao presente trabalho e consiste no produto do esforço humano que se apresenta em forma de bem imaterial ou no caso de implicar utilização de material preserva a sua natureza pela preponderância da obrigação de fazer.

O art. 593, do Código Civil, determina que a prestação de serviço que não estiver sujeita às leis trabalhistas ou à lei especial será regida pelo referido Código, cujo art. 594 prevê que toda a espécie de serviço ou trabalho lícito, material ou imaterial, pode ser contratada mediante retribuição.

De acordo com Caio Mário da Silva Pereira ${ }^{365}$, o contrato de prestação de serviços consiste em contrato em que uma das partes se obriga para com outra a fornecer-lhe a prestação de uma atividade, mediante remuneração.

Maria Helena Diniz ${ }^{366}$ defende que é um conjunto de ações ou serviços desempenhados pela pessoa.

Orlando Gomes ${ }^{367}$ possui outra definição. Para o doutrinador, a prestação de serviço submetida aos princípios de Direito Privado é contrato mediante o qual uma pessoa

\footnotetext{
365 Instituições de Direito Civil, v.3, Rio de Janeiro: Forense, 1978, , p. 33.

366 Dicionário jurídico, v.4, São Paulo: Saraiva, 1998, p. 120.

367 Contratos, Rio de Janeiro: Forense, $8^{\text {a }}$ ed., 1986, p. 343/344.
} 
se obriga a prestar serviços à outra, eventualmente, em troca de determinada remuneração, executando-os com independência técnica e sem subordinação hierárquica.

Note-se que em todas as definições estão presentes a existência de direitos e deveres recíprocos, o fornecimento de utilidade material e imaterial consistente no desenvolvimento de uma atividade humana, visando a um determinado resultado.

Prestar serviço consiste em uma relação jurídica com outra pessoa (seja física ou jurídica), sendo uma delas o prestador e a outra o tomador do serviço (ou beneficiário), vinculadas por uma obrigação de fazer (esforço humano) em contraprestação a um conteúdo econômico a ser pago.

Bernardo Ribeiro de Moraes ${ }^{368}$ ensina que no contrato de prestação de serviço, o prestador coloca sua atividade à disposição da outra parte, mediante remuneração e que o objeto do contrato é o próprio trabalho. O prestador de serviços tem uma obrigação de fazer (obrigação in faciende), em que a prestação consiste em ato ou serviço de devedor (não há "obrigação de dar", em que a prestação consiste na entrega de coisa material, móvel ou imóvel, certa ou incerta).

A obrigação de dar, por sua vez, segundo Clovis Bevilaqua ${ }^{369}$, "é a entrega de uma coisa móvel ou imóvel, seja para constituir um direito real, seja somente para facilitar o uso da coisa, ou ainda, a simples detenção, seja finalmente, para restituí-la ao seu dono”.

Não obstante as definições estanques dos dois tipos obrigacionais, nem sempre é fácil distinguir se a obrigação pactuada entre as partes consiste em um "fazer" ou em um “dar”. Não é sem razão que Orlando Gomes ${ }^{370}$, com seu olhar analítico, já antevia essas dificuldades ao pontuar que "nem sempre as obrigações são exclusivamente de dar ou de fazer; não raro, misturam-se as prestações de coisas e de fatos, classificando-se a obrigação pela predominância de uma sobre a outra."

\footnotetext{
${ }^{368}$ Doutrina, op. cit., p. 84.

${ }^{369}$ Direito das Obrigações, Rio de Janeiro: Paulo de Azevedo, $8^{\text {a }}$ Ed., 1954, p. 54.

370 Obrigações, Rio de Janeiro: Forense, 2000, p. 38.
} 
Orlando Gomes ${ }^{371}$ também defende que "a distinção entre as obrigações de dar e as de fazer deve ser traçada em vista do interesse do credor, porquanto as prestações de coisas supõem certa atividade pessoal do devedor e muitas prestações de fato exigem dação." Ele assevera que nas obrigações de dar o que interessa ao credor é a coisa que lhe deve ser entregue, pouco lhe importando a atividade do devedor para realizar a entrega, enquanto as obrigações de fazer, ao contrário, o fim é o aproveitamento do serviço contratado e que se assim não fosse, toda obrigação de dar seria de fazer, e vice-versa.

As relações jurídicas tornam-se cada vez mais complexas. São comuns os negócios jurídicos que importam transferência da titularidade da mercadoria e a concomitante prestação de esforço humano (serviço) em caráter negocial. Diante deste cenário é importante ter em mente que a obrigação de dar consiste em vínculo jurídico que impõe ao devedor a entrega de alguma coisa já existente, enquanto a obrigação de fazer impõe a execução, a elaboração, a concretização de algo até então inexistente. ${ }^{372}$

De acordo com a doutrina civilista, portanto, prestar serviço constitui uma verdadeira obrigação de fazer e, consoante já dito anteriormente, sendo o direito tributário uma seara de superposição, ou seja, que se vale de definições e realidades construídas por outros ramos do Direito, para fins de incidência do imposto municipal, os serviços de qualquer natureza devem constituir uma obrigação de fazer.

Tal entendimento, inclusive, já foi referendado pelo Supremo Tribunal Federal que reconheceu que a prestação de serviço para fins de incidência do ISS guarda íntima relação com a obrigação de fazer, ensejadora de um esforço humano dirigido a terceiro e mediante remuneração. Ao apreciar a alegação de inconstitucionalidade do gravame municipal sobre a locação de bens móveis que constava da lista anexa ao Decreto-lei no 406/68, a Corte foi enfática ao afastá-lo (reconhecendo a sua inconstitucionalidade) sob o argumento de que tal atividade consistia em uma obrigação de dar, diversa da de fazer.

371 Obrigações, op. cit., p. 38.
${ }^{372}$ Cf. BARRETO, Aires F., ISS, op. cit., p. 42/43. 
$\mathrm{O}$ voto do Ministro Celso de Mello proferido quando do julgamento do RE $\mathrm{n}^{\circ}$ 116.121-3-SP ${ }^{373}$ foi muito esclarecedor e por isso transcrevemos os seguintes trechos:

\begin{abstract}
"Tenho para mim, na mesma linha de entendimento exposta por AIRES FERNANDINO BARRETO ("Revista de Direito Tributário", vol. 38/192) e por CLÉBER GIARDINO ("Revista de Direito Tributário", vol. 38/196), que a qualificação da "locação de bens móveis", como serviço, para efeito de tributação municipal mediante incidência do ISS, nada mais significa do que a inadmissível e arbitrária manipulação, por lei complementar, da repartição constitucional de competências impositivas, eis que o ISS somente pode incidir sobre obrigações de fazer, a cuja matriz conceitual não se ajusta a figura contratual da locação de bens móveis.

Cabe advertir, neste ponto, que a locação de bens móveis não se identifica e nem se qualifica, para efeitos constitucionais, como serviço, pois esse negócio jurídico - considerados os elementos essenciais que lhe compõem a estrutura material - não envolve a prática de atos que consubstanciam um praestare ou um facere.

Na realidade, a locação de bens móveis configura verdadeira obrigação de dar, como resulta claro do art. 1.188 do Código Civil: 'Na locação de coisas, uma das partes se obriga a ceder à outra, por tempo determinado, ou não, o uso e gozo de coisa não fungível, mediante certa retribuição'."
\end{abstract}

Ao assim decidir, o STF não apenas afastou a cobrança do imposto sobre locação de bens móveis, como fixou o conceito constitucional de serviços de qualquer natureza. ${ }^{374}$

O entendimento supramencionado foi tantas vezes reiterado que acabou convertido na Súmula Vinculante $\mathrm{n}^{\mathrm{o}} 31^{375}$, segundo a qual é inconstitucional a incidência do Imposto sobre Serviços de Qualquer Natureza - ISS sobre operações de locação de bens móveis.

Além do Poder Judiciário, o Executivo já se conscientizou da definição de serviço para fins de incidência do ISS, pois ao sancionar a LC nº 116/2003, o então Presidente da

373 “TRIBUTO - FIGURINO CONSTITUCIONAL. A supremacia da Carta Federal é conducente a glosar-se a cobrança de tributo discrepante daqueles nela previstos.

IMPOSTO SOBRE SERVIÇOS - CONTRATO DE LOCAÇÃO. A terminologia constitucional do Imposto sobre Serviços revela o objeto da tributação. Conflito com a Lei Maior dispositivo que imponha o tributo considerado contrato de locação de bem móvel. Em Direito, os institutos, as expressões e os vocábulos têm sentido próprio, descabendo confundir a locação de serviços com a de móveis, práticas diversas regidas pelo Código Civil, cujas definições são de observância inafastável - artigo 110, do Código Tributário Nacional." (RE nº 116.121-3-SP, Tribunal Pleno, Ministro Relator Octavio Gallotti, DJ $11 / 11 / 2000)$.

No mesmo sentido: "PROCESSUAL CIVIL. AGRAVO REGIMENTAL. IMPOSTO SOBRE SERVIÇOS (ISS). LOCAÇÃO DE BENS MÓVEIS.

É firma o entendimento do Supremo Tribunal Federal no sentido de que não incide Imposto sobre Serviços (ISS) sobre a locação e bens móveis.

(...)" (Agravo Regimental no Agravo de Instrumento $\mathrm{n}^{\circ}$ 758.697-Rio de Janeiro, Ministro Joaquim Barbosa, DJ 06/04/2010)

374 Cf. ÁVILA, Humberto, Imposto, op. cit., p. 124.

$375<$ http://www.stf.jus.br/arquivo/cms/jurisprudenciaSumulaVinculante/anexo/Enunciados_Sumula_Vincu lante_STF_1_a_29_31_e_32.pdf>. Acesso em: 06 dez. 2012. 
República, Luiz Inácio Lula da Silva, vetou ${ }^{376}$ a inclusão da locação de bens móveis na lista anexa à referida lei justamente em razão do entendimento do STF já mencionado.

Concordamos com Humberto Ávila quando assevera que a Constituição Federal, ao utilizar o termo "serviços" na regra de competência tributária municipal, incorporou o conceito infraconstitucional pré-constitucional, qual seja, da obrigação de fazer previsto no Código Civil, cujo núcleo semântico é o esforço humano empreendido em benefício de outrem, o qual não pode ser alterado por norma infraconstitucional ou pelos operadores do Direito, sob pena de violação às regras de competência e ao princípio federativo e, com isso atentar contra a supremacia constitucional. ${ }^{377}$

Assim, pode-se dizer que o STF, desafortunadamente, atentou contra a supremacia da Constituição ao decidir, em 02.12.2009, o RE nº 592.905/SC, em que se discutia a incidência do ISS sobre leasing financeiro.

Sob a relatoria do então Ministro Eros Grau, o STF decidiu que o leasing é contrato autônomo e que muito embora resulte da fusão de elementos de outros contratos

376 Mensagem de veto n. 362/03: "Verifica-se que alguns itens da relação de serviços sujeitos à incidência do imposto merecem reparo, tendo em vista decisões recentes do Supremo Tribunal Federal. São eles: O STF concluiu julgamento de recurso extraordinário interposto por empresa de locação de guindastes, em que se discutia a constitucionalidade da cobrança do ISS sobre a locação de bens móveis, decidindo que a expressão "locação de bens móveis" constante do item 79 da lista de serviços a que se refere o DecretoLei $\mathrm{n}^{\mathrm{o}}$ 406, de 31 de dezembro de 1968, com a redação da Lei Complementar $\mathrm{n}^{\mathrm{o}}$ 56, de 15 de dezembro de 1987, é inconstitucional (noticiado no Informativo do STF no 207). O Recurso Extraordinário 116.121/SP, votado unanimemente pelo Tribunal Pleno, em 11 de outubro de 2000, contém linha interpretativa no mesmo sentido, pois a 'terminologia constitucional do imposto sobre serviços revela o objeto da tributação. Conflita com a Lei Maior dispositivo que imponha o tributo a contrato de locação de bem móvel. Em direito, os institutos, as expressões e os vocábulos têm sentido próprios, descabendo confundir a locação de serviços com a de móveis, práticas diversas regidas pelo Código Civil, cujas definições são de observância inafastável.' Em assim sendo, o item 3.01 da Lista de serviços anexa ao projeto de lei complementar ora analisado, fica prejudicado, pois veicula indevida (porque inconstitucional) incidência do imposto sob locação de bens móveis. O item 13.01 da mesma Lista de serviços mencionada no item anterior coloca no campo de incidência do imposto gravação e distribuição de filmes. Ocorre que o STF, no julgamento dos RREE 179.560-SP, 194.705-SP e 196.856-SP, cujo relator foi o Ministro Ilmar Galvão, decidiu que é legítima a incidência do ICMS sobre comercialização de filmes para videocassete, porquanto, nessa hipótese, a operação se qualifica como de circulação de mercadoria. Como conseqüência dessa decisão foram reformados acórdãos do Tribunal de Justiça do Estado de São Paulo que consideraram a operação de gravação de videoteipes como sujeita tão-somente ao ISS. Deve-se esclarecer que, na espécie, tratava-se de empresas que se dedicam à comercialização de fitas por elas próprias gravadas, com a finalidade de entrega ao comércio em geral, operação que se distingue da hipótese de prestação individualizada do serviço de gravação de filmes com o fornecimento de mercadorias, isto é, quando feita por solicitação de outrem ou por encomenda, prevalecendo, nesse caso a incidência do ISS (retirado do Informativo do STF $\mathrm{n}^{\mathrm{o}}$ 144). Assim, pelas razões expostas, entendemos indevida a inclusão destes itens na Lista de serviços."

377 ÁVILA, Humberto, Imposto, op. cit., p. 124. 
(financiamento ${ }^{378}$, compra e venda de bens ${ }^{379}$ e locação ${ }^{380}$ ), não pode ser classificado como contrato misto já que a causa do negócio é sempre o financiamento de investimentos produtivos.

Restou reconhecido, ainda, que existem 3 modalidades de leasing, mas que somente o leasing operacional ${ }^{381}$ (arrendamento mercantil) é uma locação, enquanto o leasing financeiro $^{382}$ e o lease-back $k^{383}$ são serviços.

De acordo com a referida decisão, no leasing financeiro prepondera o caráter de financiamento e nele a arrendadora, que desempenha a função de locadora surge como intermediária entre o fornecedor e o arrendatário. E, por assim dizer, a Corte entendeu que em razão de o financiamento constar da lista anexa à LC 116, trata-se de serviço tributável pelo ISS.

Muito embora o arrendamento mercantil não seja objeto do presente estudo, não se pode deixar de pontuar que o STF, a nosso ver, deixou de apreciar a questão sob o ponto de vista da competência material para legislar sobre financiamento. $\mathrm{O}$ fato de o leasing constar da lista dos serviços tributáveis não afasta eventual inconstitucionalidade, pois o Município invadiu a competência legislativa da União ao incluir tal atividade dentre os serviços tributáveis pelo ISS. ${ }^{384}$

378 Em razão de a arrendadora captar recursos financeiros para a formação de um fundo.

379 Ao término do contrato o arrendatário pode exercer a sua opção de compra mediante o pagamento do valor residual.

${ }^{380} \mathrm{O}$ arrendatário utiliza o bem de propriedade da arrendadora mediante o pagamento de prestação.

381 De acordo com o entendimento do STF, o fabricante de um bem o dá em locação a quem dele fará uso; o arrendante é o próprio produtor industrial.

${ }^{382}$ De acordo com o entendimento do STF, trata-se de modalidade clássica em que a arrendadora adquire bens de um fabricante ou fornecedor e entrega seu uso e gozo ao arrendatário, mediante pagamento de uma contraprestação periódica, ao final da locação abrindo-se a este a possibilidade de devolver o bem à arrendadora, renovar a locação ou adquiri-lo pelo preço residual combinado no contrato.

383 De acordo com o entendimento do STF, no lease back, a própria arrendatária vende um bem que lhe pertence à arrendadora e, em seguida, toma-o de volta, em arrendamento mercantil.

384 A tal título, cite-se o entendimento de Humberto Ávila: "Assim, a consideração do leasing como uma operação complexa não afasta a conclusão de que o elemento essencial de todos os atos praticados é a operação de financiamento. E a competência para a tributação da operação de financiamento é reservada à União Federal e, por via reflexa, excluída dos Municípios. Isso significa que o fato de o leasing financeiro envolver obrigações de fazer não quer dizer que tenha como fato gerador uma obrigação de fazer tributável pelos Municípios. Não basta haver uma obrigação de fazer para existir competência para a cobrança do imposto sobre serviços. Para que ela exista é necessário que a obrigação de fazer seja, de um lado, independente e, de outro, não reservada à competência de outro ente federado." (Imposto, op. cit., p.125). 
O que mais chama atenção nesta decisão é a fundamentação do voto vencedor do então Ministro Eros Grau. O Ministro Marco Aurélio, fiel ao seu entendimento anteriormente proferido quando do julgamento da não incidência do ISS sobre a locação de bens móveis ( $\mathrm{RE} \mathrm{n}^{\mathrm{o}}$ 116.121-3-SP), restou vencido. O Ministro Carlos Britto até tentou demonstrar que o financiamento pressupõe atos que denotam obrigações de fazer, porém o entendimento que preponderou foi mesmo o do Ministro Eros Grau, cujo voto sagrou-se vencedor. Confira-se:

\footnotetext{
"Em síntese, há serviços, para os efeitos de inciso III do artigo 156 da Constituição, que por serem de qualquer natureza, não consubstanciam típicas obrigações de fazer. Raciocínio adverso a este conduziria à afirmação de que haveria serviço apenas nas prestações de fazer, nos termos do que define o direito privado. Note-se, contudo, que afirmação como tal faz tabula rasa da expressão 'de qualquer natureza', afirmada do texto da Constituição. Não me excedo em lembrar que toda atividade de dar consubstancia também um fazer e há inúmeras atividades de fazer que envolvem um dar."
}

O trecho acima torna claríssimo o raciocínio do Ministro que ignora a obrigação de fazer como requisito necessário para a configuração de uma prestação de serviço, assim como se olvida que a despeito de inúmeras obrigações de fazer envolverem uma obrigação de dar, é necessário distingui-las levando-se em consideração as razões que motivaram a contratação, se pelo fazer algo ainda inexistente ou se pela entrega de coisa já existente, sob pena das duas modalidades de obrigações se equivalerem, o que é inadmissível perante o direito das obrigações.

O Ministro Eros Grau não levou em consideração o conceito de serviço firmado pela Corte quando afastou a incidência do ISS sobre a locação de bens móveis $\left(\mathrm{RE} \mathrm{n}^{\circ}\right.$ 116.121-3-SP) e, como fundamentação, adotou determinado acórdão (não informado) proferido pelo Ministro Ilmar Galvão, em que teria sido reconhecido que a LC mencionada pelo art. 156, da Constituição, ao definir serviços de qualquer natureza para fins de incidência do ISS, (a) arrola serviços por natureza; (b) inclui serviços que, não exprimindo a natureza de outro tipo de atividade, passam à categoria de serviços, para fim de incidência do tributo por força de lei, visto que, se assim não considerados, restariam incólumes a qualquer tributo; e (c) em caso de operações mistas, afirma a prevalência do serviço, para fim de tributação pelo ISS. 
Ao que parece, preocupado em não deixar a atividade de financiamento supostamente incólume a qualquer tributo, o que foge dos critérios jurídicos de avaliação, bem como visando a dar interpretação ampla à expressão de qualquer natureza, o STF reavivou e aderiu à teoria ultrapassada do caráter econômico do serviço.

No Brasil, o mais expoente defensor do conceito econômico de serviço é Bernardo Ribeiro de Moraes, para quem o conceito de serviço de qualquer natureza se opõe ao de bem material ou corpóreo, abrangendo quaisquer outras atividades que não constituam bens corpóreos na etapa de circulação econômica como, por exemplo, a locação de bem móveis e a cessão de direitos. Confira-se:

"7. Conceito de 'serviço', como o de mercadoria ou de produto, é eminentemente
econômico. A Economia classifica os bens suscetíveis de utilidade econômica
em duas classes distintas, a saber: bens materiais, ou corpóreos, que têm
extensão corpórea no espaço, como o produto, a mercadoria; bens imateriais, ou
incorpóreos, que carecem de extensão corpórea, como serviço. Estes últimos
podem abranger o 'fornecimento de trabalho' a terceiros, v.g., de advocacia, de
médico, de datilografia, de cabeleireiro etc.; a 'locação de bens móveis', como a
locação de máquinas, de veículos etc.; e a 'cessão de direitos', v.g., serviços de
venda de bilhetes de loteria, serviços de diversões públicas etc.
Para a Economia, o conceito de serviço se opõe ao de bem material ou corpóreo,
abrangendo quaisquer outras atividades que não constituam bens corpóreos na
etapa da circulação econômica.
(...) Assim, segundo o ordenamento jurídico tributário, o ISSQN tem por objeto a
circulação econômica de serviços, isto é, a prestação de serviços, consistente na
venda econômica de bens imateriais (que não sejam mercadorias ou
produtos)."”885

Em breve síntese, para os que defendem o conceito econômico de serviço, a expressão serviços de qualquer natureza deve ser interpretada a partir da utilidade econômica de apenas duas classes de bens - materiais e imateriais -, de forma abrangente e por exclusão, o que significa dizer que, para eles, os bens corpóreos são mercadorias e, por exclusão, os incorpóreos (imateriais de qualquer espécie) são serviços independentemente de haver esforço humano em beneficio de outrem. Ademais, esta corrente doutrinária não leva em consideração as definições do direito privado, notadamente a doutrina civilista sobre as obrigações de fazer.

A nosso ver, a decisão do STF representa um retrocesso. Ignorar o entendimento da própria Corte sobre o conceito de serviço de qualquer natureza enquanto uma obrigação de

\footnotetext{
385 Imposto Sobre Serviços de Qualquer Natureza, in Martins, Ives Gandra da Silva (coord.), Curso de Direito Tributário, Belém: CEJUP, 1997, p. 287/288.
} 
fazer diminui a Constituição Federal e desrespeita o conceito constitucional (pressuposto) de serviço já demonstrado, além de tornar inócuo o art. 110, do CTN que impõe que a lei tributária não pode alterar a definição, o conteúdo e o alcance dos institutos, conceitos e formas de direito privado, utilizados, expressa ou implicitamente, pela Constituição Federal, pelas Constituições dos Estados, ou pelas Leis Orgânicas do Distrito Federal ou dos Municípios, para definir ou limitar competências tributárias.

Em face das reiteradas decisões do STF que referendam a prestação de serviços de qualquer natureza como uma obrigação de fazer e desde que constem da lista anexa à LC $n^{\circ} 116 / 03$ (e da respectiva lei municipal), acreditamos que o acórdão supramencionado, que anuiu com a incidência do ISS sobre o arrendamento mercantil (modalidade financeiro), representa entendimento esparso que não há de ser recebido como uma reversão no entendimento da Suprema Corte.

\subsection{LC n ${ }^{\circ}$ 116/2003 - Item 1.05: Licenciamento ou cessão de direito de uso de programas de computação}

Já dissemos que o objeto da prestação de serviço é uma obrigação de fazer, ou seja, a prestação de uma atividade lícita, não vedada pela lei e pelos bons costumes, oriunda da energia humana aproveitada por outrem, e que pode ser material ou imaterial. ${ }^{386}$

Além disso, demonstramos que a LC no 116/03, na qualidade de lei de âmbito nacional, com fundamento de validade nos arts. 156 e 146, da Constituição, ou seja, que visa a prevenir conflitos de competência tributária, regular limitações ao poder de tributar e estabelecer normas gerais em matéria tributária, é dotada de legitimidade para "definir" os serviços de qualquer natureza que são passíveis de tributação.

Sabe-se que a lista anexa à LC no 116/03 é taxativa e que os serviços tributáveis são os que constam dos seus subitens ${ }^{387}$. Todavia, o fato de determinadas atividades constarem da referida lista não, necessariamente, assegura tratarem-se de serviços.

\footnotetext{
386 Cf. DINIZ, Maria Helena, Código Civil anotado, 10ª ed., São Paulo: Saraiva, 2004.

${ }^{387}$ Nesse sentido, Aires F. Barreto argumenta que: "Tributáveis são os serviços descritos nos subitens e não os gêneros referidos nos grupos que os aglutinam, porque esse entendimento decorre da estrutura da própria lista. Com efeito, se assim não fosse, despiciendos seriam todos eles; bastaria listar os vários grupos, sem necessidade de referir-se aos respectivos subitens. A razão motivadora do emprego do
} 
Aliás, se assim fosse, a incidência do ISS sobre a locação de bens móveis (item 3.01) não teria sido declarada inconstitucional pelo STF quando ainda vigorava o Decretolei $\mathrm{n}^{\mathrm{o}} 406 / 68$ e posteriormente acolhida pelo Poder Executivo que vetou a sua inclusão na nova lista de serviços tributáveis.

E, por assim dizer, não obstante a presunção de legalidade das leis, fato é que a lista anexa à LC $\mathrm{n}^{\circ}$ 116/03 contempla algumas atividades que a despeito de supostamente configurarem serviços, não constituem uma obrigação de fazer, motivo pelo qual também deveriam ter sido vetados e/ou sido julgados inconstitucionais pela Corte Suprema.

É o que ocorre com a atividade constante do item 1.05 da lista, qual seja, $o$ licenciamento ou cessão de direito de uso de programas de computação. ${ }^{388}$

A licença de uso de software (concessão do direito de uso) não constitui uma obrigação de fazer, mas sim uma obrigação de dar, que segundo os ensinamentos de Clovis Bevilaqua $^{389}$ "é a entrega de uma coisa móvel ou imóvel, seja para constituir um direito real, seja somente para facilitar o uso da coisa, ou ainda, a simples detenção, seja finalmente, para restituí-la ao dono."

Por conta disso, concordamos com Humberto Ávila ${ }^{390}$ quando critica a incidência do ISS sobre o leasing e diz ser inconcebível aceitar como tributável tal operação quer pelo fato de o arrendamento mercantil ter constado implicitamente da lista anexa ao DL $\mathrm{n}^{\circ}$ 406/68, quer pelo fato de estar explícito na lista anexa à LC n ${ }^{\circ} 116 / 03$. Para o tributarista, argumentar que a natureza da atividade é definida pelo legislador infraconstitucional, leva,

critério de itens e subitens, detalhando, ao máximo, os possíveis serviços (e até, inconstitucionalmente, vários não-serviços, como é o caso da locação de bens móveis e da cessão de direitos). Há, ainda, um derradeiro, mas decisivo argumento que atua como verdadeira pá de cal sobre a questão. Se a possibilidade de exigência do ISS decorresse diretamente do item, e não dos respectivos subitens, de nada adiantaria o veto presidencial a este ou àquele subitem (tal como ocorreu com o subitem 3.01, que previa a incidência do imposto sobre a locação de bens móveis). Com efeito, se assim fosse, o veto da Presidência da República a esse subitem, por inconstitucional - aposto com supedâneo na decisão do Pleno do STF (RE 116.121-3/SP), seria absolutamente inócuo, uma vez que o item (genérico que é) prosseguiria permitindo a possibilidade de exigência do tributo, nos casos de locação de bens móveis" (ISS, op. cit.,p. 121/123).

388 No mesmo sentido posiciona-se Ives Gandra da Silva Martins e Marilene Talarico Martins Rodrigues (Aspectos relevantes do ISS, Revista Dialética de Direito Tributário, $\mathrm{n}^{\circ}$ 182, São Paulo: Dialética, 2010, p. 168), bem como Hugo de Brito Machado (O ISS e a Locação ou Cessão de Direito de Uso, in Rocha, Valdir de Oliveira, coord., O ISS e a LC 116/03, São Paulo: Dialética, 2003, p. 125/139).

389 Direito, op. cit., p. 54.

390 Imposto, op. cit., p.123. 
inexoravelmente, à violação da supremacia constitucional, porquanto define o conteúdo da norma superior pela inferior, sobrepondo a lei à Constituição.

Conforme sustentamos desde o início, a expressão "compra de software" é comumente utilizada com equivocada conotação, pois as transações mais comuns que envolvem os programas de computador consistem, a bem da verdade, na obtenção de uma licença de uso, que nada mais é que a concessão de autorização para a utilização sob condições. A mais balizada doutrina tributarista representada por Aires F. Barreto é de idêntico pensar, confira-se:

\begin{abstract}
"Pelo contrato de licença de uso, o titular de um direito de propriedade intelectual (do direito autoral) concede a outra pessoa o direito de usar a referida propriedade intelectual, exclusivamente ou não, a título oneroso ou gratuito. Não há transferência da propriedade intelectual entre licenciador e licenciado. O licenciado não adquire a propriedade da coisa licenciada, mas tão-somente o direito ao seu uso.

Com efeito, na relação jurídica de licença de uso de software, o que se verifica é a permissão do uso do software por meio do contrato de licença de uso (não a transferência da propriedade). Esta relação jurídica sempre se instaura entre o titular dos direitos autorais do programa (licenciador) e os seus usuários (licenciado). A simples posse de cópia do software não dá ao usuário o direito de seu uso, que somente se legitima com o contrato de licença ou, segundo determina o parágrafo único do art. $9^{\circ}$, da Lei do software, na sua falta, o documento fiscal relativo à aquisição ou licenciamento de cópia servirá para comprovação da regularidade do seu uso.

Disso decorre não ser juridicamente correto falar-se em "compra e venda de software", dada a natureza jurídica da relação de licença de uso entre o licenciador e o licenciado (e na qual se tem por objeto um bem incorpóreo).

Dentre as cessões de direito, incluem-se a licença de uso de software. Na relação jurídica de uso de software o licenciador ou sublicenciador cede ao licenciado o direito de que é titular de usar a referida propriedade intelectual, mediante remuneração ou não. Há, rigorosamente, a cessão do direito de uso de um bem, que, em virtude de sua natureza incorpórea, é um bem imaterial. Nesta operação, o titular dos direitos autorais do software (licenciador) entrega o bem ao interessado, para que possa usá-lo exclusivamente ou não, a título oneroso ou gratuito. Não há, pois, na espécie, esforço físico ou intelectual do cedente que possa caracterizar uma prestação de serviço, mas verdadeira cessão de direito, da espécie licença de uso, cuja natureza é típica de uma obrigação de dar. ${ }^{391}$
\end{abstract}

No mesmo sentido é a opinião de Marcelo Caron Baptista ${ }^{392}$, para quem a cessão de direito sobre bem imaterial consiste em uma relação contratual cuja prestação independe de esforço humano, pois, não aperfeiçoa o comportamento necessário à configuração do critério material da hipótese de incidência do ISS. Ele defende que se trata de uma prestação-fim de dar, consistente em transferir os direitos de uso e gozo de bem imaterial a terceiro.

391 ISS, p. 139.

392 ISS - Do Texto à Norma, São Paulo: Quartier Latin, 2007, p. 352. 
Diante disso, o licenciamento ou a cessão de direito de uso de programas de computação não se subsumem ao conceito de serviço tributável para fins de incidência do ISS.

A adequada tributação da (con)cessão de direitos ${ }^{393}$ como, por exemplo, a licença de uso de programas de computador, deve ser concretizada pela União mediante o exercício da sua competência residual, nos termos do art. 154, I, da Constituição Federal, já que a cessão de direito sobre bem imaterial não constitui hipótese de incidência de nenhum tributo constitucionalmente previsto.

\subsection{A questão do ISS sobre a licença de uso do software desenvolvido sob encomenda e do software híbrido}

Ao fazer uma agradável digressão histórica sobre a tutela jurídica da obra fruto da criação do autor, Plínio Cabral $^{394}$ rememora a época renascentista em que o direito autoral já era reconhecido, muito embora não se reconhecesse a propriedade material sobre as criações, porque o produto, geralmente cópia única, era entregue ao encomendante.

Ao julgar o RE no 176.626-3, o STF acolheu o entendimento de Rui Saavedra, segundo o qual os programas feitos sob encomenda são desenvolvidos a partir das exigências do seu encomendante, de modo a satisfazer as suas necessidades, enquanto os programas adaptados ao cliente constituem uma forma híbrida entre os programas "de prateleira" e os que são produzidos sob encomenda.

A depender dos termos da contratação, a prestação de serviço de elaboração de programas de computador pode ensejar também a concessão do direito de uso (licenciamento). Prestação de serviço e licença de uso são institutos distintos e que podem estar presentes na contratação do desenvolvimento de software por encomenda.

\footnotetext{
${ }^{393}$ Vale lembrar que a transferência definitiva do direito de exploração patrimonial da obra é denominada de cessão de direitos autorais, enquanto a transferência temporária para o exercício de direito patrimonial, denomina-se concessão de direito autoral (VENOSA, Silvio de Salvo, Direito Civil-Contratos em Espécie, São Paulo: Atlas, 2005, p. 649).

394 CABRAL, Plínio, A Nova, op. cit., p. 4.
} 
Pautado no entendimento de Clélio Chiesa, Aires F. Barreto ${ }^{395}$ defende justamente o contrário, ou seja, que a contratação de um software sob encomenda não encerra um esforço humano tributável pelo ISS, mas apenas uma cessão de direitos de uso (licença).

Desafortunadamente, sobre este aspecto não podemos concordar com os citados doutrinadores.

A nosso ver, a contratação de determinado profissional para executar, elaborar ou concretizar algo até então inexistente constitui uma prestação de serviços consubstanciada em uma obrigação de fazer. Ademais, ao contratar o tal profissional, o contratante especifica os detalhes do serviço a ser executado e as exigências a serem cumpridas, o que torna a atividade personalizada, executada sob medida e, consequentemente, sob encomenda.

O nosso entendimento encontra guarida nos ensinamentos de Orlando Gomes ${ }^{396}$ para quem "nas obrigações de dar o que interessa ao credor é a coisa que lhe deve ser entregue, pouco lhe importando a atividade do devedor para realizar a entrega, enquanto as obrigações de fazer, ao contrário, o fim é o aproveitamento do serviço contratado.”

Portanto, acreditamos que a contratação do desenvolvimento de programa de computador se dá sob encomenda, já que o contratante tem interesse pela criação do bem que ainda inexiste e que será elaborado de acordo com as suas exigências. Em outras palavras, a contratação se dá em razão da expectativa de que a expertise do profissional posta em prática e à disposição do contratante resulte em um bem que atenda às suas necessidades e exigências.

\footnotetext{
395 "Quando o usuário contrata um profissional para confeccionar um programa de computador não está interessado no esforço físico e intelectual que será consumado com a realização do trabalho, mas no resultado: o programa segundo as especificações que pactuou. O negócio entabulado, como dito, poderá compreender somente a cessão do direito de uso ou a cessão dos próprios direitos autorais. Com efeito, em ambas as hipóteses não há caracterização do trabalho, mas cessão de direitos, que não constitui a materialidade do ISS. (...) De igual forma, a aquisição de um software sob encomenda não pode ser qualificada como um negócio jurídico entabulado entre tomador e prestador de serviços que tem por objeto uma mera prestação de serviço em caráter oneroso, mas num negócio jurídico de cessão do direito de uso do programa ou a cessão da propriedade dos direitos autorais relativos ao programa encomendado." (ISS, op. cit., p. 143/144).

${ }^{396}$ Obrigações, op. cit., p. 38.
} 
A elaboração de um programa sob encomenda pressupõe o esforço humano de determinado profissional desempenhado na concretização dos ideais do contratante, motivo pelo qual acreditamos tratar-se de uma prestação de serviço (obrigação de fazer) prevista no item 1.04 (elaboração de programas de computadores) da lista dos serviços tributáveis pelo ISS.

Entretanto, não se pode confundir a prestação de serviço de elaboração de programas de computadores com o licenciamento ou a cessão de direito de uso de programas de computação.

Conforme já expusemos, não concordamos com a classificação tripartite adotada pelo STF quando do julgamento do RE $n^{\circ}$ 176.626-3, quer em razão da lei do software não acolher tal classificação, quer em razão de não se tratar de fator de discrímen juridicamente apto a designar a incidência de tal ou qual tributo, como - implicitamente - faz crer a decisão (embora assim não tenha sido reduzida a termo).

Aliás, a majoritária doutrina e jurisprudência (pautados apenas na ementa do julgado e no fato de a referida classificação tripartite ter sido acolhida pelo STF) acredita que a Corte teria decidido que o software "de prateleira" (produzido em larga escala) é mercadoria tributada pelo ICMS, enquanto os programas de computador executados sob encomenda ou aqueles já existentes, mas que são adaptados (híbridos) para atender às necessidades de cada contratante, são tributados pelo ISS.

Contrariando tal posicionamento, estamos convictos de que ao julgar o $\mathrm{RE} \mathrm{n}^{\mathrm{o}}$ 176.626-3 o STF decidiu o mérito do recurso que é a não incidência do ICMS sobre as operações de licenciamento ou de cessão de direito de uso de programas de computador, muito embora tenha acolhido a classificação tripartite de software sugerida por doutrinador estrangeiro e de fazer breves considerações acerca do ISS e do ICMS.

Considerando que todas as transações com programas de computador que se destinam ao uso estão atreladas a um contrato de licença de uso, seja em caso de software "de prateleira", "sob encomenda" ou "híbrido", outra conclusão não se admite senão a de que a outorga de autorização para o uso se dá por licença (licenciamento), que constitui uma obrigação de dar e é objeto de contrato próprio. 
$\mathrm{O}$ mesmo não pode ser dito em relação à elaboração de programas de computadores que constitui uma obrigação de fazer e é um serviço previsto na lista anexa à LC $n^{\circ} 116 / 03$, motivo pelo qual sofre a incidência do ISS.

Portanto, na contratação da elaboração de um programa de computador as partes podem pactuar livremente sobre o contratante adquirir também a concessão da licença de uso do programa ou se o contratante passa a ser proprietário dos direitos autorais patrimoniais de autor, dispensando-se, assim, a licença.

A prestação de serviço de elaboração de software, a licença de uso e/ou a concessão de direitos autorais patrimoniais são institutos autônomos que subsistem de maneira independente.

Isso nos permite elucidar que para fins de incidência do imposto municipal é necessário segregar o licenciamento ou a cessão de direito de uso de programas de computação (item 1.05) da elaboração de programa de computadores (item 1.04), já que a primeira atividade consiste em uma obrigação de dar que não guarda identidade com o critério material (prestar) serviços de qualquer natureza integrante da regra-matriz de incidência tributária do ISS.

Neste sentido, oportunas são as palavras de José Eduardo Soares de Melo ${ }^{397}$ quanto a não incidência do ISS sobre a licença de uso por entender que o software é obra intelectual cuja utilização por terceiros não implica uma obrigação de fazer que possa justificar a incidência do imposto, mas uma cessão de direitos (obrigação de dar), sem efetiva natureza mercantil, razão pela qual se revela inconstitucional a sua inclusão na lista de serviços.

Não obstante o nosso posicionamento, não podemos deixar de mencionar que nos termos do art. $4^{\text {o }}$, da Lei $n^{\circ} 9.609 / 98$, os programas desenvolvidos em decorrência da

397 Inconstitucionalidades da LC no $116 / 03$, in Imposto sobre Serviços - ISS na Lei Complementar $n^{\circ} 116 / 03$ e na Constituição, São Paulo: Manole, 2004, p. 312. 
relação de emprego, prestação de serviço ou vínculo estatutário, pertencerão exclusivamente ao empregador ou ao contratante, salvo disposição em contrário. ${ }^{398}$

Seria dizer que se não houver disposição em contrário no contrato, os programas de computador elaborados sob encomenda (prestação de serviço) passam a pertencer ao contratante, ou seja, o software fruto da prestação de serviço passa desde logo a pertencer ao encomendante, que gozará dos direitos patrimoniais de autor, tendo acesso, inclusive, ao seu código-fonte, sem a necessidade do licenciamento do direito do seu uso, afinal ele será "proprietário" do bem. Inclusive, este é o entendimento de Marcelo Caron Baptista:

\begin{abstract}
"A lei é suficientemente clara ao estabelecer, como regra geral, salvo disposição contratual em contrário, que os direitos sobre o bem imaterial (software), quando ele for criado por encomenda do tomador, passarão a integrar o seu patrimônio jurídico ab initio, não havendo uma cessão de direito propriamente dita. Ao contrário do que ocorre com outros bens imateriais, em que eles são criados e posteriormente cedidos, os direitos correspondentes, pelo autor a terceiro, o programa de computador já aparece no mundo jurídico como bem do contratante (tomador).

(...)

Em relação ao software, a hipótese de sua criação sob encomenda é a única materialidade que se ajusta ao antecedente normativo do ISS, equiparável aos demais serviços prestados pelo setor de informática.

As relações de simples transferência de direitos sobre o programa não ensejam qualquer possibilidade de dúvida. Sobre elas não incide o tributo municipal, e sua presença na Lista de Serviços anexa à Lei Complementar 116/03 - item ' 1.05 - licenciamento ou cessão de direito de uso de programas de computação' - ostenta inconstitucionalidade incontornável." ${ }^{, 399}$
\end{abstract}

É por esse motivo que não concordamos com Aires F. Barreto cujo entendimento já foi transcrito, tão pouco com Clélio Chiesa ${ }^{400}$ que sustenta que a contratação de um software sob encomenda não envolve um negócio jurídico de prestação de serviço. Ambos acreditam que a cessão de direito de uso dos programas de computador elaborado sob encomenda é incindível.

$\mathrm{Na}$ nossa opinião tal argumento é frágil. É pressuposto da contratação que o software sequer ainda exista. Afinal, a contratação é justamente para que seja desenvolvido determinado programa de acordo com a vontade do contratante. Ou seja, antes do

\footnotetext{
${ }^{398}$ Não se pode esquecer que a autoria é um direito moral irrenunciável e inalienável do autor, de modo que é a transmissão dos direitos autorais patrimoniais que confere poderes a outrem para a exploração econômica da obra (WILLINGTON, João e OLIVEIRA, Jaury N. de, A nova, op. cit., p. 19).

${ }^{399}$ ISS - Do Texto à Norma, São Paulo: Quartier Latin, 2007, p. 358/360.

${ }^{400}$ Inconstitucionalidades da LC $n^{\circ} 116 / 03$, in Imposto sobre Serviços - ISS na Lei Complementar no 116/03 e na Constituição, São Paulo: Manole, 2004, p. 341.
} 
licenciamento ser concretizado (se é que haverá dado que em caso de omissão, o programa passa a pertencer ao contratante, nos termos da lei), o programa precisa ser desenvolvido e aí consiste a obrigação de fazer correspondente ao item 1.04 da lista anexa à LC no 116/03. Aliás, ninguém concede direitos de uso de bem inexistente.

Ao se manifestarem sobre os programas de computador desenvolvidos sob encomenda, Carlos Alberto Bittar e Carlos Alberto Bittar Filho foram categóricos quanto à configuração de uma prestação de serviço e quanto à intransferibilidade dos direitos autorais sobre o programa em favor do encomendante que tiver pactuado apenas a concessão do direito de uso (salvo em caso de disposição contratual em contrário) ${ }^{401}$ :

\footnotetext{
"Não mudam os termos da equação nem a iniciativa de outrem para sua criação, nem mesmo a remuneração do criador para esse fim, na denominada 'obra de encomenda', inclusive quando empregado do encomendante.

De fato, o direito de autor promana da criação da obra, ou seja, da ação de introduzir no mundo fático a forma protegida, literária, artística ou científica. Justifica-o o vínculo pessoal, ou seja, o elo espiritual que entrelaça autor e obra intelectual.

O encomendante não adquire senão o direito de utilização da obra no modo ajustado em função das finalidades próprias da obra. Qualquer uso que extrapole a esses limites deve ser, previamente, solicitado ao autor e autorizado por escrito, através de contratos próprios, pagando-se-lhe a remuneração devida.

Esse contínuo laço que prende a obra ao autor persiste, sob o aspecto pessoal, indelevelmente, pela eternidade, mantendo íntegra a criação e sob o nome do criador e o título por ele conferido.

Sob o aspecto patrimonial, permite-se a fruição pelo autor, por toda a sua vida, e também pela de certos herdeiros, limitando-se, o uso, ao revés, quando a obra cai no domínio público, ficando livre da exclusividade autoral.

Na criação autônoma de obra intelectual, em que o criador produz sozinho a obra, permanecem em sua esfera jurídica todos os direitos autorais, facultado ao encomendante o uso no fim específico contratado e nos limites definidos no ajuste.

Nessa hipótese, ao encomendante compete somente a utilização específica ajustada." ${ }^{402}$
}

Já em relação ao software híbrido não vislumbramos qualquer prestação de serviço, mas tão somente a concessão de licença para o seu uso, pois o programa pelo qual o contratante se interessa já existe e é utilizado por outros interessados.

401 Carlos Alberto Bittar já havia se manifestado no mesmo sentido quando da vigência da antiga Lei do Software ( $\mathrm{n}^{\circ}$ 7.646/87). A tal título vide Contratos de Comercialização de "Software", in Novos Contratos Empresariais, São Paulo: RT, 1990, p. 44/46.

402 BITTAR, Carlos Alberto e FILHO, Carlos Alberto Bittar, Tutela dos Direitos da Personalidade e dos Direitos Autorais nas Atividades Empresariais, São Paulo: RT, 2002, p. 84/86. 
O programa híbrido recebe este nome por ser decorrente de um software previamente existente, mas que sofre adaptações pontuais com vistas a proporcionar o seu adequado funcionamento e integração com os sistemas de dados do contratante.

O programa híbrido é comumente conhecido como software de gestão. Trata-se de programa sofisticado, de elevado valor agregado, muito utilizado em grandes corporações com o objetivo de interligar - via sistema eletrônico de dados - todos os departamentos da empresa em âmbito nacional e internacional como, por exemplo, as áreas de suprimentos, produção, comercial/vendas, finanças, recursos humanos, folha de pagamento, recrutamento e seleção, etc., otimizando desempenho e resultados das atividades e um gerenciamento mais eficaz.

A nosso sentir, as adaptações executadas pelo autor do programa não podem ser consideradas uma prestação de serviço de elaboração de programas de computadores (item 1.04, da lista anexa à LC no 116/03) ou qualquer outra atividade constante da lista, pois quando a parte contrata o fornecimento de software (híbrido), este já está pronto e acabado.

Ademais, a utilização do mesmo software híbrido pode ser - como geralmente é contratada por diversas empresas diferentes, com a única peculiaridade de serem feitos ajustes específicos para que o programa se adeque a cada uma das realidades empresariais, afinal, nem todas as empresas possuem as mesmas áreas de negócios ou praticam as mesmas metodologias.

Tal constatação nos faz afirmar que o autor do software híbrido não é contratado para desenvolver um programa específico que atenda às necessidades do cliente, pelo contrário, os contratantes têm interesse justamente no programa que já existe ${ }^{403}$ (e que possivelmente os seus concorrentes utilizam como potente ferramenta de gestão e de otimização dos resultados), mas que dada à complexidade das suas configurações e por conta da finalidade pela qual foi inicialmente criado, requer sejam realizadas adaptações.

\footnotetext{
403 A despeito de ser um software que parte de um núcleo pré-existente (daí dizer que ele é originalmente um programa padrão que sofre adaptações) que pode ser contratado por qualquer interessado, por conta do seu elevado grau de complexidade e sofisticação não pode ser instalado diretamente pelo contratante como os programas "de prateleira". Trata-se de programa que requer técnicos especializados para procederem à sua instalação e garantir o seu adequado funcionamento.
} 
Para configurar a prestação de serviço do item 1.04 o programa deve ser concebido desde a origem de modo perfeito e acabado de forma a atender às necessidades do contratante, sem que seja necessário proceder às adaptações e em muitos casos com direito à exclusividade.

Não há que se falar em prestação de serviço que precise sofrer reparos ou que não atenda desde o início às necessidades do cliente, lembrando que o serviço é prestado por solicitação do cliente/contratante e não do autor/contratado. No caso do software híbrido, o bem é desenvolvido por livre e espontânea vontade do autor/contratado.

Além disso, as adaptações, ajustes e eventuais modificações realizadas no software a fim de colocá-lo em pleno funcionamento não consistem em atividade-fim da contratação e somente os serviços-fim é que podem ser tributados pelo ISS.

Deveras, na contratação de um programa híbrido destinado ao uso, o que se pretende é obter a respectiva licença (fim perseguido) que não se transmuda em serviço pelo simples fato de, para viabilizar ou facilitar essa concessão, vir-se a fornecer determinadas adaptações. A obrigação segue sendo de dar e não de fazer. ${ }^{404}$

Não são raras as vezes que é necessário executar diversas atividades-meio para a consecução do serviço-fim que consta do objeto social do prestador de serviço. Contudo, aquelas não podem ser desmembradas do processo que envolve a prestação de serviço-fim e serem tidas como atividades autônomas constituidoras de serviço-fim para serem individualmente tributadas.

Em se tratando de contratação envolvendo software híbrido, a atividade-fim do contratado (concessão de direito de uso/licenciamento/licença de uso) sequer pode ser tida como uma prestação de serviço (obrigação de fazer), em que pese constar do item 1.05 da lista anexa à $L C n^{\circ} 116 / 03$.

Em sendo as atividades-meio (adaptações), necessárias à concessão de licença de uso do software, para que este funcione adequadamente como concebido e prometido ao

${ }^{404}$ Cf. BARRETO, Aires F., ISS, op. cit., p. 143. 
contratante, as adaptações no programa híbrido não podem ser desmembradas do todo e serem tidas como prestação de serviço para fins de incidência do ISS.

Neste aspecto, uma vez mais nos valemos da opinião de Aires F. Barreto ${ }^{405}$ que com veemência afirma que tributável é o serviço-fim, isto é, o esforço humano prestado a terceiros como fim ou objeto e não as suas etapas, passos ou tarefas intermediárias, necessárias à obtenção do fim.

Ainda que as adaptações no software híbrido sejam realizadas para que o contratante delas tire proveito, fato é que sem elas a atividade-fim (concessão da licença de uso) não se perfaz, pois o cliente não há de aceitar um programa que não desempenhe as tarefas para as quais foi concebido, divulgado e oferecido. Portanto, as adaptações constituem atividades-meio indispensáveis para que o autor concretize a sua atividade-fim, a qual não configura uma prestação de serviços.

\subsection{A tributação dos serviços provenientes do exterior ou cuja prestação se tenha iniciado no exterior do País}

Grande parte dos programas de computador utilizados no Brasil são originários de outros países, de modo que a maioria das licenças de uso concedidas a usuários brasileiros são concedidas por empresas estrangeiras.

Em face da celeuma havida quanto ao licenciamento ou cessão de direito de uso de programas de computação (item 1.05) constituir (ou não) uma obrigação de fazer passível de ser tributada pelo ISS, bem como em razão da contratação de software sob encomenda envolver, a nosso ver, a prestação de serviço de elaboração de programas de computadores (item 1.04), entendemos por bem tratar da questão da taxação da importação de serviços.

${ }^{405}$ Regime, op. cit., p. 136. 
Uma das inovações mais relevantes instituídas pela LC n $116 / 03$ é a tributação dos serviços provenientes do exterior ou cuja prestação se tenha iniciado no exterior do país, prevista no seu art. $1^{\circ}$, parágrafo $1^{\mathrm{o} 406}$.

Em conformidade com a regra geral do art. $5^{\circ}$, da $\operatorname{LC~}^{\circ} 116 / 03$, o contribuinte do imposto mesmo na importação de serviços continua sendo o seu prestador, embora a lei atribua ao tomador ou intermediário dos serviços a responsabilidade tributária pelo recolhimento do ISS (art. $6^{\circ}$, parágrafo $2^{\circ}, I^{407}$ ).

A importação de serviços figura entre as exceções à regra geral do local onde se considera prestado o serviço e devido o imposto (Município em que se localiza o estabelecimento prestador), pois, em conformidade com o disposto no inciso I do artigo $3^{\circ}$, da LC $\mathrm{n}^{\mathrm{o}} 116 / 03^{408}$, o serviço considera-se prestado e o imposto devido no local do estabelecimento do tomador ou intermediário do serviço ou, na falta de estabelecimento, onde ele estiver domiciliado.

Não obstante o esforço da lei complementar, fato é que a Constituição nada dispõe sobre a incidência do ISS sobre a importação de serviços, de modo que a sua exigência se mostra inconstitucional.

406 “Art. $1^{\text {o }}$ O Imposto Sobre Serviços de Qualquer Natureza, de competência dos Municípios e do Distrito Federal, tem como fato gerador a prestação de serviços constantes da lista anexa, ainda que esses não se constituam como atividade preponderante do prestador.

$\S 1^{\circ} \mathrm{O}$ imposto incide também sobre o serviço proveniente do exterior do País ou cuja prestação se tenha iniciado no exterior do País. (...)"

407 “Art. $5^{\circ}$ Contribuinte é o prestador do serviço.

Art. $6^{\circ}$ Os Municípios e o Distrito Federal, mediante lei, poderão atribuir de modo expresso a responsabilidade pelo crédito tributário a terceira pessoa, vinculada ao fato gerador da respectiva obrigação, excluindo a responsabilidade do contribuinte ou atribuindo-a a este em caráter supletivo do cumprimento total ou parcial da referida obrigação, inclusive no que se refere à multa e aos acréscimos legais.

$\S 1^{\circ}$ Os responsáveis a que se refere este artigo estão obrigados ao recolhimento integral do imposto devido, multa e acréscimos legais, independentemente de ter sido efetuada sua retenção na fonte.

$\S 2^{\circ}$ Sem prejuízo do disposto no caput e no $\S 1^{\circ}$ deste artigo, são responsáveis:

I - o tomador ou intermediário de serviço proveniente do exterior do País ou cuja prestação se tenha iniciado no exterior do País;

II - a pessoa jurídica, ainda que imune ou isenta, tomadora ou intermediária dos serviços descritos nos subitens 3.05, 7.02, 7.04, 7.05, 7.09, 7.10, 7.12, 7.14, 7.15, 7.16, 7.17, 7.19, 11.02, 17.05 e 17.10 da lista anexa."

408 “Art. $3^{\circ} \mathrm{O}$ serviço considera-se prestado e o imposto devido no local do estabelecimento prestador ou, na falta do estabelecimento, no local do domicílio do prestador, exceto nas hipóteses previstas nos incisos I a XXII, quando o imposto será devido no local:

I - do estabelecimento do tomador ou intermediário do serviço ou, na falta de estabelecimento, onde ele estiver domiciliado, na hipótese do $\S 1^{\circ}$ do art. $1^{\circ}$ desta Lei Complementar;

$(\ldots)^{\prime \prime}$ 
Vale lembrar que a Constituição reservou aos Estados a competência para tributar as operações relativas à circulação de mercadorias e sobre a prestação de serviços de transporte intermunicipal ou interestadual e de comunicação, ainda que iniciados no exterior, ficando com o Município a competência para tributar os serviços de qualquer natureza definidos em lei complementar.

A constituição é ainda mais explícita sobre a incidência do ICMS sobre a

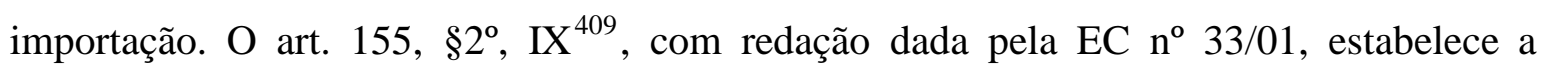
incidência do imposto quando da importação de bem ou mercadoria por pessoa física ou jurídica (independente da finalidade) ou sobre serviço prestado no exterior.

Contudo, o mesmo não pode ser dito em relação ao ISS, já que a Carta Magna nada diz a respeito da importação de serviços de qualquer natureza (apenas sobre a possibilidade de a lei complementar excluir as exportações de serviços para o exterior da incidência do imposto - art. $156, \S 3^{\circ}$, inciso II).

Antes das alterações da Constituição não se admitia a incidência do ICMS sobre os serviços prestados no exterior, tão pouco sobre as importações perpetradas por pessoa física (consumidor final). Aires F. Barreto é de idêntico pensar:

"Vê-se, pois, que a Constituição, relativamente ao ICMS, na sua redação
primeira do caput do art. 155 , já previra a incidência do imposto, mesmo em face
de operações e prestações iniciadas no exterior, e no inciso IX do parágrafo $2^{\circ}$ do
art. 155 , estendera-a para alcançar (a) a entrada de mercadoria importada do
exterior, assim como sobre (b) o serviço prestado no exterior.
(...)
Mais não seria preciso para reconhecer que, sem essas novas ampliações da
competência dos Estados membros, não seria possível viabilizar essas
exigências. Em outras palavras, se o constituinte assim o fez, foi precisamente
por estar convencido de que, até então, dita competência não estava assegurada

409 “Art. 155 - Compete aos Estados e ao Distrito Federal instituir impostos sobre:

(...)

II - operações relativas à circulação de mercadorias e sobre prestações de serviços de transporte interestadual e intermunicipal e de comunicação, ainda que as operações e as prestações se iniciem no exterior;

(...)

$\S 2 .^{\circ} \mathrm{O}$ imposto previsto no inciso II atenderá ao seguinte

(...)

IX - incidirá também: a) sobre a entrada de bem ou mercadoria importados do exterior por pessoa física ou jurídica, ainda que não seja contribuinte habitual do imposto, qualquer que seja a sua finalidade, assim como sobre o serviço prestado no exterior, cabendo o imposto ao Estado onde estiver situado o domicílio ou o estabelecimento do destinatário da mercadoria, bem ou serviço;

$(\ldots)$ " 
aos Estados membros pelo sistema jurídico constitucional então vigente. Fez-se necessária expressa inclusão dessa possibilidade, pela via adequada da Emenda, a demonstrar não só que ela não estava contida na competência anteriormente atribuída, mas para evidenciar, ainda, sua não tolerância com interpretações que arguissem com a existência de uma possível competência implícita."410

Em inúmeros julgados ${ }^{411}$ proferidos sob a égide do texto constitucional em vigor antes da EC n ${ }^{\circ} 33 / 01$, o STF afastou a exigência do ICMS por conta da ausência de previsão constitucional que resguardasse a sua incidência e por entender que a pessoa física não poderia ser tida como contribuinte por não ser comerciante e não poder gozar do direito ao crédito (não-cumulatividade).

Ao julgar o RE no 203.075-9/DF ${ }^{412}$, sob a relatoria do então Ministro Ilmar Galvão, o STF afastou a incidência do ICMS sobre a importação de um veículo levada a efeito por uma pessoa física. No seu voto, o então Ministro Carlos Velloso consignou que se o contribuinte é o vendedor, numa importação não haveria pagamento do ICMS, pelo simples motivo de o exportador estar no exterior, de modo que foi preciso que a Constituição estabelecesse, expressamente, a incidência do tributo na importação e que o seu pagamento seria feito pelo comprador, ou seja, pelo importador.

Diferentemente do que ocorre com o ICMS, a Constituição Federal não autoriza a incidência do ISS sobre a importação dos serviços provenientes do exterior ou cuja prestação se tenha iniciado no exterior do país. Não obstante isso, há que se reconhecer que a doutrina não é uníssona a respeito da matéria.

Alberto Macedo ${ }^{413}$ defende que nem todos os critérios da regra-matriz de incidência tributária estão postos na Constituição e que no caso do ISS coube ao legislador

${ }^{410}$ ISS - Não incidência sobre a importação de serviços, Revista Dialética de Direito Tributário, $\mathrm{n}^{\circ}$ 201, São Paulo: Dialética, 2012, p. 20.

${ }^{411}$ Vide RE no 185.789-7/SP e RE no 203.075-9/DF.

412 "RECURSO EXTRAORDINÁRIO. CONSTITUCIONAL. TRIBUTÁRIO. PESSOA FÍSICA. IMPORTAÇÃO DE BEM. EXIGÊNCIA DE PAGAMENTO DO ICMS POR OCASIÃO DO DESEMBARAÇO ADUANEIRO. IMPOSSIBILIDADE.

1. A incidência do ICMS na importação de mercadoria tem como fato gerador operação de natureza mercantil ou assemelhada, sendo inexigível o imposto quando se tratar de bem importado por pessoa física.

2. Princípio da não-cumulatividade do ICMS. Pessoa física. Importação de bem. Impossibilidade de se compensar o que devido em cada operação com o montante cobrado nas anteriores pelo mesmo ou outro Estado ou pelo Distrito Federal. Não sendo comerciante e como tal não estabelecida, a pessoa física não pratica atos que envolvam circulação de mercadoria. Recurso extraordinário não conhecido." (STF, $1^{\text {a }}$ Turma, RE nº 203.075-9, Ministro Relator Ilmar Galvão, DJ 05/08/98)

${ }^{413}$ ISS e PIS-COFINS-Importação, op. cit., p. 17. 
complementar determinar elementos de conexão de forma a definir seus critérios espacial e pessoal, já que a Carta Magna não prescreve apenas uma possibilidade de critério pessoal. Para ele, em face da mencionada liberdade, o legislador estabeleceu - de forma legítima o contribuinte do imposto nas prestações de serviços internacionais, qual seja, o tomador ou intermediário do serviço proveniente do exterior.

Com base em tal premissa e valendo-se de um conceito de serviço de qualquer natureza mais abrangente (notadamente em razão das decisões proferidas pelo $\mathrm{STF}^{414}$ sobre a incidência do ISS sobre o leasing financeiro), Alberto Macedo sustenta a constitucionalidade da incidência do imposto municipal sobre a importação de serviços a partir do dispositivo que desonera as exportações:

\footnotetext{
"Na Lei Complementar no 116/03, apesar de ela não ser tão expressa quando trata de definir o conceito de importação de serviço, o é quando define a negativa de exportação de serviço, deixando clara a distinção entre o local do desenvolvimento do serviço ('serviços desenvolvidos no Brasil') e aquele onde o resultado se verifica ('cujo resultado aqui se verifique'). (...) Assim, se o local do desenvolvimento (ou da execução) do serviço for distinto (em outro país) do local do resultado do serviço, haverá uma prestação internacional de serviços. Caso contrário, a prestação de serviço será intranacional." ${ }^{415}$
}

O doutrinador defende não apenas a incidência do ISS sobre os serviços integral ou parcialmente executados no Brasil, como também sobre aqueles executados no exterior, mas cujo resultado aqui se verifique. Tal entendimento amplia o conceito de serviço dando mais importância ao produto da prestação de serviço, o que nos parece equivocado, na medida em que esta consiste no esforço humano desenvolvido em favor de outrem.

Em que pese a exportação de serviços não ser objeto do presente estudo, tendo em vista que o mencionado doutrinador vale-se do dispositivo legal que trata da desoneração das exportações para anuir com a taxação da importação de serviços, não se pode deixar de mencionar que ao julgar o RESP n ${ }^{\circ} 831.124 / R J$, o STJ decidiu que a empresa que pleiteava o reconhecimento da desoneração da exportação dos serviços de reparo, retífica e revisão de turbinas e de motores em favor de empresas sediadas no exterior, deveria ser submetida à tributação do ISS em razão do objeto da contratação, ou seja, do seu resultado (conserto de equipamentos) ocorrer integralmente no Brasil.

\footnotetext{
414 Vide acórdãos do RE no 547.245/SC e RE no 592.205/SC.

415 ISS e PIS-COFINS-Importação, op. cit., p. 20.
} 
Em outras palavras, a Corte não reconheceu a existência de uma exportação justamente em razão de todo o serviço ter sido executado em sólo nacional e independentemente de as peças consertadas ("o resultado") serem remetidas ao exterior e de lá serem usufruídos os benefícios do serviço prestado. O STJ prestigiou o conceito de serviço até aqui demonstrado, consistente no esforço humano em detrimento do seu resultado propriamente dito (isoladamente considerado). ${ }^{416}$

Todavia, sob a justificativa de buscarem a coerência da LC $\mathrm{n}^{\mathbf{0}}$ 116/03, muitos doutrinadores como, por exemplo, Luís Eduardo Schoueri ${ }^{417}$, partem do conceito de exportação de serviço para interpretar o dispositivo que dispõe sobre a sua importação. ${ }^{418}$

Para essa corrente doutrinária, o legislador complementar adotou o princípio do destino para reger o comércio internacional de bens e de serviços e que não havendo indicação em sentido contrário, a importação e exportação são uma única espécie de operação e que, portanto, as exportações não devem ser tributadas (pois serão tributadas no destino/exterior), enquanto as importações assim devem ser. ${ }^{419}$

A partir do dispositivo que desonera a exportação de serviço (art. $2^{\circ}$, I, § único, da LC $n^{\circ} 116 / 03^{420}$ ) tal corrente doutrinária acredita que - mutatis mutandi - os serviços desenvolvidos no exterior e cujo resultado ali se verifique (cumulativamente), ainda que o pagamento seja feito por residente no Brasil, não configura a importação de serviços e que

416 Trechos do voto do Ministro Relator José Delgado bem ilustram o referido posicionamento: "Importante observar que a empresa não é contratada para instalar os motores e turbinas após o conserto, hipótese em que o serviço se verificaria no exterior, mas, tão somente, conforme já posto, é contratada para prestar o serviço de reparos, retífica ou revisão. Portanto, o trabalho desenvolvido não configura exportação de serviço, pois o objetivo da contratação, ou seja, o seu resultado, que é o efetivo conserto do equipamento, é totalmente concluído no território brasileiro. Não há configuração de hipótese em que a atividade é executada no exterior, sendo inquestionável a incidência do ISS no presente caso. Tem aplicação, portanto, o disposto no parágrafo único, do art. $2^{\circ}$, da LC $\mathrm{n}^{\circ} 116 / 03$ : 'Não se enquadram no disposto no inciso I os serviços desenvolvidos no Brasil, cujo resultado aqui se verifique, ainda que o pagamento seja feito por residente no exterior'."

417 ISS sobre a Importação de Serviços do Exterior, Revista Dialética de Direito Tributário, $\mathrm{n}^{\circ}$ 100, São Paulo: Dialética, 2004, p. 43.

${ }^{418}$ SCHOUERI, Luís Eduardo, ISS, op. cit., p. 44/45.

419 Cf. SCHOUERI, Luis Eduardo, ISS, op. cit., p. 45.

420 “Art. $2^{\mathrm{o}} \mathrm{O}$ imposto não incide sobre:

- as exportações de serviços para o exterior do País;

(...)

Parágrafo único. Não se enquadram no disposto no inciso I os serviços desenvolvidos no Brasil, cujo resultado aqui se verifique, ainda que o pagamento seja feito por residente no exterior." 
esta somente se perfaz se o serviço for desenvolvido em território nacional ou se o seu resultado aqui ocorrer. ${ }^{421}$

Em complementação ao argumento acima, Luís Eduardo Schoueri ${ }^{422}$ acredita que a regra constitucional de competência do imposto municipal não deposita ênfase na materialidade prestar serviço e que não apenas os serviços prestados no exterior (e concluídos no Brasil), como também os serviços executados integralmente no exterior, mas cujo resultado aqui se verifique podem configurar importação de serviços passíveis de tributação pelo ISS:

\begin{abstract}
"Deve-se notar que não parece cabível questionar a constitucionalidade da lei complementar pelo fato de o desenvolvimento do serviço ocorrer no exterior. Afinal, enquanto o constituinte, ao versar sobre o imposto estadual, depositou ênfase em seu aspecto material (operações relativas à circulação de mercadoria e prestação de serviços de transporte interestadual e intermunicipal e de comunicação) - o que exigiu que o próprio constituinte tratasse de admitir sua incidência para os casos de importações - no caso do imposto municipal, vê-se que este incide sobre os serviços de qualquer natureza. Daí, pois, a possibilidade de tributar-se um serviço cujo resultado verifique-se no País, ainda que seu desenvolvimento (a prestação propriamente dita) tenha ocorrido no exterior".
\end{abstract}

Em excelente tese de livre-docência apresentada à Faculdade de Direito da Universidade de São Paulo, o Professor Gerd Willi Rothmann, ao discorrer sobre o ISS, aduz que o imposto não incide sobre a atividade do prestador de serviços, mas sobre o resultado desta atividade (que consiste em bem incorpóreo):

\footnotetext{
"Objeto tributável é, pois, a materialização do serviço, ou seja, a utilidade material ou imaterial, proporcionada ao tomador/consumidor do serviço.

(...)

Devido a esta sua natureza, a legislação complementar pode estabelecer a incidência do ISS e a competência para sua cobrança, tanto em função do local do estabelecimento ou domicílio do prestador do serviço, como do local do estabelecimento ou domicílio do tomador do serviço materializado, ou, ainda, do local da execução do serviço.

(...)

Como o objeto tributável do ISS não é a atividade em si, mas a entrega da materialização da prestação de serviço ao tomador/consumidor, a afirmação de que, na importação de serviços, a prestação dá-se, integralmente, no exterior, carece de fundamento nos fatos e no direito, tanto nacional como internacional. Somente se pode falar em importação de serviços, se eles, ou melhor, a utilidade por eles criada chega a ser entregue ao tomador, residente e domiciliado no Brasil. Somente neste momento, a prestação do serviço pode ser considerada concluída, permitindo ao Município da residência do tomador a exigência do
}

421 Cf. SCHOUERI, Luis Eduardo, ISS, op. cit., p. 45.

${ }^{422}$ ISS, op. cit., p. 39/51. 
ISS, em consonância com o princípio de Direito Internacional Tributário do destino e a legislação constitucional brasileira.

Isto decorre da própria natureza jurídica do ISS. Sob o aspecto jurídico, o ISS, da mesma forma que o ICMS, incide sobre a circulação de bens, neste caso de bens incorpóreos. (...),

Em que pese o entendimento acima seja construído sobre sólidas bases jurídicas, parece-nos contraditório sustentá-lo nestes termos. O ilustre Professor deposita ênfase no resultado do serviço (enviado do exterior ao Brasil) a fim de justificar a incidência do ISSimportação e reconhece que o que diferencia o ISS do ICMS é a corporalidade do bem a ser tributado e que para haver a incidência do gravame municipal, aquele há de ser incorpóreo. Tal assertiva denota a sua adesão à linha de pensamento sustentada por Bernardo Ribeiro de Moraes e do então Ministro Eros Grau, com os quais não concordamos por razões já anteriormente expostas.

Em outra passagem da memorável tese em que o Professor aborda a impropriedade da lei complementar ter adotado o prestador do serviço como contribuinte do ISSimportação, ele argumenta que "da simples interpretação literal do $\S 1^{\circ}$, do Art. $1^{\circ}$ da Lei Complementar $\mathrm{n}^{\circ}$ 116/03 decorre que o serviço 'proveniente do exterior' é aquele prestado, perfeito e acabado no exterior, enquanto que o 'iniciado no exterior' terá uma parte prestada no País." 424

A passagem supratranscrita nos leva a crer que o legislador depositou ênfase no esforço humano desenvolvido em favor de outrem. Afinal, se assim não fosse, ou seja, se a ênfase estivesse no produto da prestação de serviço, por qual razão teria dito que o imposto incide inclusive sobre os serviços cuja prestação se tenha iniciado no exterior, já que ao depositar ênfase no resultado o resultado chegaria ao Brasil de qualquer forma?

A nosso ver, o ISS não incide sobre o resultado obtido com a prestação do serviço, mas sobre o esforço pessoal do prestador exercido com o objetivo de satisfazer os interesses do contratante. Entender o contrário é dizer que as obrigações de dar também podem ser alcançadas pelo imposto municipal. Se assim fosse, toda obrigação de fazer seria sobreposta por uma obrigação de dar, que ao final prevaleceria tornando letra morta a distinção entre as duas.

${ }_{424}^{423}$ Inconstitucionalidade, op. cit., p. 63/64.

${ }^{424}$ Inconstitucionalidade, op. cit., p. 80/81. 
Heleno Taveira Tôrres também se posiciona no mesmo sentido ao ponderar que "a competência dos Municípios somente pode ser exercida, seja o serviço prestado por residente ou não-residente, quando possa ser materialmente vinculado ao território da entidade tributante, mesmo que se tenha iniciado no exterior, mas sempre quando o fazer do serviço seja concluído em tal território." ${ }^{425}$

Não concordamos com a doutrina que defende a adoção do princípio do destino (que não está expressamente previsto) a fim de justificar a constitucionalidade da incidência do ISS sobre a importação de serviços, pois a Constituição depositou ênfase na materialidade prestar serviço de qualquer natureza (e não o seu gozo, fruição ou resultado dela decorrente) ainda que implicitamente e a partir de um conceito de serviço pressuposto, advindo do direito privado (esforço humano em favor de outrem, mediante remuneração e sob regime de direito privado), conforme já fartamente exposto.

O entendimento de José Eduardo Soares de Melo ${ }^{426}$ reforça a tomada de posição adotada neste estudo, pois "o cerne da materialidade da hipótese de incidência do imposto não se circunscreve a serviço, mas a uma prestação de serviço, compreendendo um negócio jurídico pertinente a uma obrigação de fazer, de conformidade com os postulados e diretrizes do direito privado".

A conceituação de serviço como uma atividade humana corrobora o entendimento de que a regra-matriz constitucional de incidência do ISS tem como aspecto material a prestação de serviços, de forma que o que dá ensejo ao nascimento do dever de pagar o imposto é o desenvolvimento de uma atividade humana. Neste sentido, valiosos são os ensinamentos de Aires F. Barreto ${ }^{427}$ :

"É lícito afirmar, pois, que serviço é uma espécie de trabalho. É o esforço
humano que se volta para outra pessoa; é o fazer desenvolvido para outrem. O
serviço é, assim, um tipo de trabalho que alguém desempenha para terceiros.
Não é esforço desenvolvido em favor do próprio prestador, mas de terceiros.
Conceitualmente, parece que são rigorosamente procedentes essas observações.
O conceito de serviço supõe uma relação com outra pessoa, a quem se serve.
Efetivamente, se é possível dizer-se que se fez um trabalho 'para si próprio'.

425 Prestações de serviços provenientes do exterior ou cuja prestação se tenha iniciado no exterior, in Imposto sobre Serviços - ISS na Lei Complementar no 116/03 e na Constituição, São Paulo: Manole, 2004, p. 284.

${ }^{426}$ ISS - Aspectos, op. cit., p. 33.

${ }^{427}$ ISS, op. cit., p. 29. 
Em outras palavras, pode haver trabalho sem que haja relação jurídica, mas só haverá serviço no bojo de uma relação jurídica.

Num primeiro momento, pode-se conceituar serviço como todo esforço humano desenvolvido em benefício de outra pessoa (em favor de outrem). Assim, o gênero trabalho é esforço humano (em sentido próprio favor ou no de terceiros) e a espécie serviço é apenas o esforço humano desenvolvido em benefícios de terceiros."

Agregue-se a isso a criatividade do legislador ao eleger o tomador do serviço como responsável tributário (verdadeiro contribuinte, diga-se de passagem, não obstante a previsão legal que o tem como substituto). Em uma primeira leitura, até é possível adotar norma como simples substituição tributária, mas uma análise mais cautelosa denuncia que há indevida ampliação da hipótese de incidência do imposto, passando a albergar não apenas a "prestação de serviços", como também o ato de "tomar serviços", ${ }^{428}$

Além de a Constituição não permitir a incidência do ISS sobre a importação de serviços tal qual autoriza a incidência do ICMS, ainda que assim permitisse, ante a definição de serviços de qualquer natureza adotada no presente estudo, não se poderia admitir a sua incidência sobre o serviço executado integralmente no exterior, falecendo argumentos para se defender que a sua utilidade ou o seu resultado verificado no Brasil é o bastante para configurar do respectivo fato gerador e legitimar a tributação.

Admitir a incidência do ISS-importação sobre serviços provenientes do exterior é admitir a sua incidência sobre o resultado da prestação de serviço, o qual não está contido na regra-matriz constitucional da exação municipal, pelas razões já expostas.

Apesar de o art. 146, da Constituição estabelecer que a lei complementar é competente para definir os tributos e suas espécies, os respectivos fatos geradores, bases de cálculo e contribuintes, é bem verdade que sua aplicação de forma a ampliar a competência outorgada a torna inconstitucional. Alberto Xavier ${ }^{429}$ bem discorre a respeito:

"A missão da lei complementar, nos termos do art. 146, III, “a”, consiste na definição dos respectivos fatos geradores, bases de cálculo e contribuintes. 'Definir' significa determinar a extensão e os limites de um conceito,

${ }^{428}$ Assim defende Clélio Chiesa: "O evento tributado, então, não é o ato de prestar serviços, mas o ato de tomar serviços provenientes do exterior. A pessoa sujeita à tributação não é o prestador, mas o tomador. Há uma inversão do contribuinte, pois não é mais o prestador que é colocado na condição de destinatário constitucional do Imposto sobre Serviços - ISS, mas o tomador do serviço.” (Inconstitucionalidades, op. cit., p. 333/334).

429 Tipicidade da Tributação, Simulação e Norma Antielisiva, São Paulo: Dialética, 2002, p. 23 
enunciando de modo preciso os seus atributos essenciais e específicos. A 'definição' da lei complementar é, pois uma função estritamente interpretativa do núcleo essencial do conceito constitucional, de modo a torná-lo determinado. No que concerne ao núcleo dos elementos essenciais do tributo, nenhuma originalidade pode ter a lei complementar, relativamente à Constituição, no que concerne ao núcleo dos elementos essenciais do tributo: não podendo inovar para além da Constituição, pois esta traça os limites máximos do poder de tributar."

Ainda que a Constituição delegue à lei complementar a tarefa de definir os serviços tributáveis e autorize-a excluir a exportação de serviços da incidência do ISS, não se pode fazer interpretação a contrario sensu para ampliar as faixas de competência tributária exaustivamente fixadas pela Constituição. ${ }^{430}$

A Constituição impõe limites às competências tributárias de cada ente tributante, de modo que cada regra de atribuição de competência tributária exerce uma função dúplice, na medida em que, ao prever as situações em que determinada competência pode ser exercida, estabelece que toda e qualquer situação que se encontra fora de seu campo de incidência encontra-se excluída da tributação. ${ }^{431}$

Ao estabelecer que os Municípios possuem competência para instituir imposto sobre serviços de qualquer natureza definidos em lei complementar e que compete à referida lei excluir as exportações da incidência do ISS, a Constituição determina, simultaneamente, que eles não têm competência para tributar a importação de serviços.

A incidência do ISS sobre os serviços executados integralmente no exterior, mas cujo resultado aqui se verifique também enseja conceder, indevidamente, às leis municipais o atributo da extraterritorialidade, fazendo os Municípios alcançarem a prestação de serviços que ocorre fora do seu território. Esse é o posicionamento de Anna Emilia Cordelli Alves ${ }^{432}$, para quem a disposição do $\S 1^{\circ}$, do art. $1^{\circ}$, da LC n ${ }^{\circ} 116 / 03$, "atribui extraterritorialidade à lei municipal, alcançando, inclusive, o serviço prestado integralmente no exterior, de modo a tributar, em verdade, não só o serviço realizado

\footnotetext{
${ }^{430}$ Cf. BARRETO, Aires F., ISS - Não incidência sobre a importação de serviços, Revista Dialética de Direito Tributário, $\mathrm{n}^{\circ}$ 201, 2012, p. 25.

${ }^{431}$ Cf. BALEEIRO, Aliomar, Limitações Constitucionais ao Poder de Tributar, Rio de Janeiro: Forense, 1997, p. 2.

${ }^{432}$ ISS - Aspectos, op. cit., p. 29.
} 
parcialmente no exterior e parcialmente no País, mas também a importação ${ }^{433}$ de serviço por tomador domiciliado no País."

Esta extraterritorialidade outorgada pela lei complementar também viola a regramatriz de incidência tributária do ISS extraída da Constituição que só permite a tributação da prestação de serviços (obrigação de fazer) ocorrida nos limites territoriais dos Municípios brasileiros.

Em que pese a LC no 116 disponha que, em relação à importação dos serviços, o serviço considera-se prestado no Município onde estiver localizado o estabelecimento tomador ou intermediário do serviço, fato é que tal disposição não está em consonância com os limites espaciais impostos pela Constituição, em respeito ao princípio da territorialidade das leis municipais.

Independentemente do critério utilizado para fins de determinação do local da prestação (localização do estabelecimento prestador/tomador ou da efetiva prestação do serviço), a ocorrência do fato gerador do imposto encontra-se sempre vinculada aos limites territoriais do Município brasileiro.

Há que se ressaltar que o Superior Tribunal de Justiça (RESP $\left.n^{\circ} 54.002 / P E\right)$ já declarou inconstitucional a extraterritorialidade de lei municipal ao apreciar o art. 12, do

${ }^{433}$ No mesmo sentido: "Com efeito, a tributação do ISS sobre serviços provenientes do exterior faz com que o imposto municipal recaia não sobre a prestação de serviços em si, mas sobre a atividade de importá-los, a qual não se encontra contida na regra-matriz constitucional do ISS.” (SILVA, Sérgio André R. G. da, Considerações acerca da incidência do ISS sobre serviços prestados no exterior, Revista Dialética de Direito Tributário, n 104, São Paulo, 2004, p. 94).

434 No mesmo sentido: "Demonstra-se, de modo contundente, que os sujeitos não-residentes não podem ser tributados, no Brasil, por fatos praticados no exterior, por absoluta falta de conexão entre sua atividades (conexão material) com o ordenamento local. (...) Toda tributação de atos de serviços deve ser fundamentada por um vínculo material entre o prestador do serviço e os limites espaciais do território, porque a territorialidade mais não é do que a eficácia que exsurge da existência de um ordenamento jurídico vigente." (TÔRRES, Heleno Taveira, Prestações de serviços provenientes do exterior ou cuja prestação se tenha iniciado no exterior, in Imposto sobre Serviços - ISS na Lei Complementar $n^{\circ} 116 / 03$ e na Constituição, São Paulo: Manole, 2004, p.285); “Ora, o primado da territorialidade exige que o fato jurídico tributável ocorra dentro dos limites territoriais do Brasil. Essa situação comporta exceções, como visto, mas nenhuma delas está a permitir que serviços prestados no exterior, por pessoa estabelecida no exterior, seja tributada no Brasil." (RONCAGLIA, Marcelo Marques, O ISS e a Importação e Exportação de Serviços, Revista Dialética de Direito Tributário, no 129, São Paulo: Dialética, 2006, p. 104); "Por outro lado, em havendo estabelecimento prestador no exterior do país e o fato jurídico tributário ocorrer dentro dos limites territoriais de um dos Municípios brasileiros caracterizada estará a importação de serviços." (MOURA, Fabio Clasen de, A relevância da fonte de pagamento em relação à incidência do ISS sobre operações internacionais de serviços, Revista de Direito Tributário Internacional, $\mathrm{n}^{\circ}$ 7, 2007 , Quartier Latin: São Paulo, p. 42). 
DL n ${ }^{\circ}$ 406/68 que, ao tratar do aspecto espacial da regra-matriz de incidência do ISS, considerava como local da prestação dos serviços o território do Município onde se localizava o estabelecimento prestador.

Não obstante a ausência de previsão constitucional acerca da incidência do ISS sobre a importação de serviços, ainda que se admita válida a disposição da LC no 116/03 neste aspecto, acreditamos que apenas os serviços prestados integral ou parcialmente em território nacional por um não residente podem ser tributados, sob pena de ofensa à definição constitucional pressuposta da expressão prestação de serviços de qualquer natureza já esmiuçada neste trabalho, consistente em uma obrigação de fazer.

Portanto, se a prestação de serviço é desenvolvida no exterior, não há que se falar na incidência do ISS quando da entrega do seu resultado no Brasil, pelo simples fato de a lei municipal brasileira não ter aptidão para alcançar fatos ocorridos fora do seu território. É o que determina o princípio da territorialidade da lei em matéria tributária. 


\section{OUTROS ASPECTOS CONTROVERTIDOS DA TRIBUTAÇÃO DO USO DE SOFTWARE - BREVES CONSIDERAÇÕES}

Exporemos, na sequência, breves considerações a respeito do PIS-importação, da COFINS-importação, da CIDE e do IRRF incidentes sobre os rendimentos enviados ao exterior a título de contraprestação pela obtenção da licença de uso de software, sem a pretensão de esgotar os intrincados assuntos ou esmiuçar todas as desconformidades com a Constituição que os referidos tributos possam apresentar. Além disso, a análise não leva em consideração o direito tributário internacional.

\subsection{Contribuição para o Financiamento da Seguridade Social (COFINS) e Contribuição para os Programas de Integração Social e de Formação do Patrimônio do Servidor Público (PIS/PASEP) incidentes na importação}

A EC no 42/2003 alterou os artigos 149, §2 II $^{435}$ e 195, IV $^{436}$, da Constituição Federal e inovou ao prever a incidência de contribuições sociais sobre a importação de bens, produtos ${ }^{437}$ e serviços. Assim, com fundamento nos mencionados dispositivos, a Lei

435 “Art. 149. Compete exclusivamente à União instituir contribuições sociais, de intervenção no domínio econômico e de interesse das categorias profissionais ou econômicas, como instrumento de sua atuação nas respectivas áreas, observado o disposto nos arts. 146, III, e 150, I e III, e sem prejuízo do previsto no art. $195, \S 6^{\circ}$, relativamente às contribuições a que alude o dispositivo.

(...)

$\S 2^{\circ}$ As contribuições sociais e de intervenção no domínio econômico de que trata o caput deste artigo:

(...)

II - incidirão também sobre a importação de produtos estrangeiros ou serviços;"

436 “Art. 195. A seguridade social será financiada por toda a sociedade, de forma direta e indireta, nos termos da lei, mediante recursos provenientes dos orçamentos da União, dos Estados, do Distrito Federal e dos Municípios, e das seguintes contribuições sociais:

(...)

IV - do importador de bens ou serviços do exterior, ou de quem a lei a ele equiparar."

${ }^{437}$ Nas palavras de Guilherme Cezaroti, o produto advém da atividade industrial, que é atividade que tem como objeto a mudança ou alteração de bens para torná-los aptos a satisfazer as necessidades ou desejos, enquanto a mercadoria é um bem corpóreo objeto de circulação econômica (Breves considerações a respeito da incidência do ICMS, in Schoueri, Luís Eduardo (coord.), Internet - O Direito na Era Virtual, Rio de Janeiro: Forense, 2001, p. 156). Sebastião de Oliveira Lima sustenta que "o produto é gênero do qual mercadoria é espécie e conceituado o primeiro como sendo um bem móvel e corpóreo, enquanto que o segundo é um bem móvel, corpóreo objeto de circulação econômica" ( $O$ fato gerador do imposto de importação na legislação brasileira, São Paulo: Revista dos Tribunais, 1981, p. 45/46). 
$\mathrm{n}^{\mathrm{o}} 10.865 / 04$ instituiu a COFINS e a contribuição para o PIS, ambas na modalidade importação ${ }^{438}$.

Tal inovação objetiva a neutralidade fiscal no comércio internacional para que não faça diferença se os bens ou serviços são obtidos no mercado interno ou no exterior já que os importados passam a ser onerados com a "mesma" carga fiscal que os nacionais. ${ }^{439}$

É o que se extrai da exposição de motivos da MP $n^{\circ} 164 / 04$, posteriormente convertida na Lei $n^{\circ} 10.865 / 04$, que justifica a instituição das novas contribuições como medida para equalizar, mediante tratamento isonômico, a tributação dos bens e serviços produzidos no Brasil com a tributação dos importados do exterior. ${ }^{440}$

A instituição das contribuições em exame pode ser tida como a concretização do princípio do destino orientador da neutralidade no comércio internacional, pautado na desoneração das exportações e na tributação das importações. Neste aspecto, é importante lembrar que a EC n $3 / 93$ passou a permitir a não-incidência do ISS sobre a exportação de serviços, enquanto a EC no 33/01 desonerou as receitas de exportação (art. 149, §2º I, da CF) e, por fim, a EC $n^{\circ} 42 / 03$ passou autorizar a incidência das contribuições sobre as importações de bens e de serviços.

É bem verdade que o mencionado ideal de neutralidade possui razão de ser, mas o que não se diz é que a eleição da espécie contribuição social para garantir a isonomia, também tem outra finalidade que é a não repartição das respectivas receitas com os demais entes federados.

O art. 195, da Constituição informa que a seguridade social será financiada por toda a sociedade, de forma direta e indireta. Tendo em vista que a COFINS-importação tem como fundamento de validade o art. 195, IV, da Constituição, trata-se de contribuição

\footnotetext{
${ }^{438}$ A despeito da identidade de terminologias com as contribuições instituídas pelas $L C \mathrm{n}^{\circ} 7 / 70$ (PIS) e $\mathrm{n}^{\mathrm{o}}$ 70/91 (COFINS), tratam-se de contribuições distintas. Estas últimas incidem sobre o faturamento ou receita bruta e encontram fundamento de validade no art. 195, I, "b", da Constituição Federal.

439 Cf. MACEDO, Alberto, ISS e PIS-COFINS-Importação, op. cit., p. 10.

440 O Professor Gerd Willi Rothmann acredita que o PIS e a COFINS incidentes na importação são, na verdade, meros adicionais do imposto de importação de produtos estrangeiros e que constituem grave invasão de competência tributária dos Estados e dos Municípios, titulares da competência de instituir o ICMS e o ISS, respectivamente (Inconstitucionalidade, op. cit., p. 120).
} 
social securitária, cuja receita destina-se a custear a seguridade social (direitos à saúde, à previdência e à assistência social, nos termos do art. 194). ${ }^{441}$

O PIS-importação é uma contribuição social geral por ter como fundamento de validade o art. $149, \S 2^{\circ}$, II, da Constituição. ${ }^{442}$

O caput do art. $1^{\text {o }}$, da Lei $\mathrm{n}^{\mathrm{o}} 10.865 / 04^{443}$ determina que o PIS incide sobre a importação de produtos estrangeiros ou serviços e a COFINS incide sobre a importação de bens estrangeiros ou serviços do exterior. Especificamente quanto aos serviços, o $\S 1^{\circ}$, do art. $1^{\circ}$ também estabelece que serão tributados os que forem provenientes do exterior, prestados por pessoas física ou jurídica residentes ou domiciliadas no exterior, executados no Brasil ou executados no exterior com resultados verificados aqui.

De acordo com o art. $3^{\circ}$, I e II, da Lei $n^{\circ} 10.865 / 04^{444}$, o fato gerador das contribuições é a entrada de bens estrangeiros no território nacional ou a entrega/remessa de valores a residentes ou domiciliados no exterior em razão da importação de serviços.

Em que pese a Lei $n^{\circ}$ 10.865/04 nada tenha dito sobre a incidência das contribuições sobre a obtenção (de licença de uso) de software do exterior, muito se discute a respeito.

O software "de prateleira” oriundo do exterior não gera muitos questionamentos, na medida em que na importação de bens/produtos a base de cálculo das contribuições é a

${ }^{441}$ Cf. PIMENTA, Paulo Roberto Lyrio, Cofins-importação e PIS/PASEP-importação: Contribuições interventivas inconstitucionais, Revista Dialética de Direito Tributário, nº 113, 2005, p. 94/95.

442 Nos termos do RE $n^{\circ} 138.284 / C E$.

443 “Art. 1ํㅡㄹ Ficam instituídas a Contribuição para os Programas de Integração Social e de Formação do Patrimônio do Servidor Público incidente na Importação de Produtos Estrangeiros ou Serviços PIS/PASEP-Importação e a Contribuição Social para o Financiamento da Seguridade Social devida pelo Importador de Bens Estrangeiros ou Şerviços do Exterior - COFINS-Importação, com base nos arts. 149, $\S 2^{\circ}$, inciso II, e 195, inciso IV, da Constituição Federal, observado o disposto no seu art. $195, \S 6^{\circ}$.

$\S 1^{\text {ㅇ }}$ Os serviços a que se refere o caput deste artigo são os provenientes do exterior prestados por pessoa física ou pessoa jurídica residente ou domiciliada no exterior, nas seguintes hipóteses:

I - executados no País; ou

II - executados no exterior, cujo resultado se verifique no País. (...)"

444 “Art. $3^{\circ} \mathrm{O}$ fato gerador será:

I - a entrada de bens estrangeiros no território nacional; ou

II - o pagamento, o crédito, a entrega, o emprego ou a remessa de valores a residentes ou domiciliados no exterior como contraprestação por serviço prestado.

$(\ldots) "$ 
mesma utilizada para o imposto de importação, ou seja, o valor aduaneiro (acrescido, todavia, do ICMS incidente no desembaraço aduaneiro e do valor das próprias contribuições). ${ }^{445}$

Considerando que a Portaria MF nº 181/89 e a Instrução Normativa SRF no 327/03 determinam que, para fins de imposto de importação, o valor aduaneiro de suporte informático que contenha dados ou instruções (software) para equipamento de processamento de dados é determinado considerando unicamente o custo ou o valor do suporte propriamente dito, desde que o custo ou o valor dos dados ou instruções esteja destacado no documento de aquisição, pode-se dizer que o PIS e a COFINS devem incidir sobre a mesma base (valor aduaneiro = valor do suporte físico).

A parte inovadora da Lei $\mathrm{n}^{\mathrm{o}}$ 10.865/04 que amplia o conceito de valor aduaneiro para incluir os valores do ICMS/ISS e o das próprias contribuições quer para a importação de bens/produtos, quer para a importação de serviços, é de duvidosa legalidade ${ }^{446}$ e constitucionalidade $\mathrm{e}^{447}$.

O conceito de valor aduaneiro ${ }^{448}$ como sendo o preço realmente pago ou por pagar pelas mercadorias quando estas forem vendidas para exportação (podendo ser acrescido de outros valores vinculados à operação, tais como os custos de frete, seguro e carga/descarga) há muito tempo está definido em acordos internacionais subscritos pelo Brasil $^{449}$ e internalizados na ordem jurídica como, por exemplo, no Acordo de Valoração Aduaneira (que visa a disciplinar os parâmetros para aferição da base de cálculo nas operações de comércio internacional) para a implementação do art. VII do GATT. ${ }^{450}$

${ }^{445}$ Contudo, há que se mencionar que a base de cálculo ampliada pelo acréscimo do ICMS e das próprias contribuições é passível de questionamento.

446 Vide os arts. 98 e 110 , do CTN.

${ }^{447}$ Vide Art. $5^{\circ}, \S 2^{\circ}$, da Constituição.

${ }^{448}$ Nos termos do art. 77, do Decreto no 6.759/09 (Regulamento Aduaneiro), o valor aduaneiro é o valor da transação comercial acrescido dos valores das atividades vinculadas à operação: frete, seguro e carga/descarga.

449 A ata final que incorpora os resultados da Rodada Uruguai de Negociações Comerciais do GATT foi ratificada pelo Decreto Legislativo $\mathrm{n}^{\circ} 30 / 94$ e promulgada pelo Decreto ${ }^{\circ}$ 1.355/94.

${ }^{450}$ Cf. SANTI, Eurico Marcos Diniz de; PEIXOTO, Daniel Monteiro, PIS e COFINS na importação, competência: entre regras e princípio, Revista Dialética de Direito Tributário, $\mathrm{n}^{\circ} 121$, São Paulo: Dialética, 2005, p. 42. 
Não obstante isso, os principais questionamentos envolvendo os programas de computador estão relacionados com a contratação de importação de serviços e com a obtenção de licença de uso, muitas vezes tratada como prestação de serviço ${ }^{451}$. A Autoridade Fiscal Administrativa exige o PIS e a COFINS quando da remessa ao exterior dos respectivos pagamentos.

A questão é tão controvertida que a Autoridade Fiscal Administrativa por diversas vezes alterou o seu entendimento para exigir as contribuições. Inicialmente, o órgão não conferia maiores explicações para exigir o PIS e a COFINS, in verbis:

\footnotetext{
"Solução de Consulta no 50/06, da Superintendência Regional da Receita Federal da $4^{\mathrm{a}}$ Região Fiscal

ASSUNTO: Contribuição para o PIS/Pasep

EMENTA: CONTRIBUIÇÃO PARA O PIS/PASEP NA IMPORTAÇÃO DE BENS E SERVIÇOS. FATO GERADOR. PROGRAMA DE COMPUTADOR. O fato gerador da Contribuição para o PIS/Pasep na importação de programa de computador ocorre na entrada deste no País, bem como na remessa ao exterior de importância destinada ao pagamento da respectiva licença de uso, objeto de contrato de exploração econômica de direito de autor."
}

Posteriormente, passou a entender que a concessão de licença de uso de software constituía prestação de serviço (o que não se sustenta ante as razões já expostas) e que, por conseguinte, o pagamento correspondente remetido ao exterior configurava importação de serviços:

\begin{abstract}
"Solução de Consulta n ${ }^{\circ}$ 46/07, da Superintendência Regional da Receita Federal da $8^{\mathrm{a}}$ Região Fiscal ASSUNTO: Contribuição para o Financiamento da Seguridade Social - Cofins EMENTA: IMPORTAÇẪO DE SERVIÇOS (Programas de Computador) Licença de Uso. FATO GERADOR As importâncias pagas, creditadas, entregues, empregadas ou remetidas ao exterior a título de remuneração mensal pelo direito de uso dos programas de computador - software, constituem fato gerador da Cofins, por se tratar de serviço executado no exterior, cujo resultado se verifica no país. BASE DE CÁLCULO Constitui base de cálculo da Cofins, o
\end{abstract}

451 “Solução de Consulta no 35/11, da Superintendência Regional da Receita Federal da 8 a Região Fiscal. Assunto: Contribuição para o PIS/Pasep. Ementa: PAGAMENTOS AO EXTERIOR A TÍTULO DE LICENÇA OU CESSÃO DE USO DE SOFTWARE. As importâncias pagas, creditadas, entregues, empregadas ou remetidas ao exterior a título de remuneração pelo direito de uso de programa de computador - software, constituem fato gerador da Contribuição para o PIS/Pasep- Importação , por se tratar de serviço executado no exterior, cujo resultado se verifica no país. Dispositivos Legais: Lei Complementar $\mathrm{n}^{\circ}$ 116, de 2003, item 1 subitem 1.05, da Lista de serviço s anexa; Lei no 10.865 , de 2004 , art. $1^{\circ}, \S 1^{\circ}$, inciso II. Assunto: Contribuição para o Financiamento da Seguridade Social - Cofins . PAGAMENTOS AO EXTERIOR A TÍTULO DE LICENÇA OU CESSÃO DE USO DE SOFTWARE. As importâncias pagas, creditadas, entregues, empregadas ou remetidas ao exterior a título de remuneração pelo direito de uso de programa de computador, software, constituem fato gerador da Cofins - Importação , por se tratar de serviço executado no exterior, cujo resultado se verifica no país." 
valor pago, creditado, entregue, empregado ou remetido para o exterior, antes da retenção do imposto de renda, acrescido do Imposto sobre Serviços de qualquer Natureza - ISS e do valor das próprias contribuições.”

"Solução de Consulta no 236/07, da Superintendência Regional da Receita Federal da $7^{\text {a }}$ Região Fiscal

ASSUNTO: Contribuição para o PIS/Pasep

EMENTA: PROGRAMAS DE COMPUTADOR. LICENÇA DE USO. IMPORTAÇÃO DE SOFTWARE. IMPORTAÇÃO DE SERVIÇO. O contrato de licenciamento de uso de software contratado à empresa situada e domiciliada no exterior trata-se de importação de serviço e, como tal, se submete, inequivocamente, à incidência dessa Contribuição Social. Fundamentação Legal: Lei n ${ }^{\circ} 10.865$, de 30 de abril de 2004, art. $1^{\circ}$."

Em 2009, a Receita Federal - de forma mais coerente - passou a reconhecer a não incidência das contribuições sobre a contraprestação pela licença de uso (afinal de contas não se trata de serviço, mas de autorização de uso de obra intelectual protegida pelo direito autoral) e opinar pela tributação apenas dos valores representativos da remuneração pela implementação e execução do software (prestação de serviços):

\footnotetext{
"Solução de Consulta n 13/09, da Superintendência Regional da Receita Federal

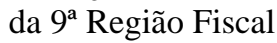

ASSUNTO: Contribuição para o Financiamento da Seguridade Social - Cofins EMENTA: LICENÇA DE USO DE SOFTWARE. NÃO INCIDÊNCIA DA COFINS-IMPORTAÇÃO. INCIDÊNCIA EM RELAÇÃO AOS SERVIÇOS VINCULADOS. Não incide a COFINS-Importação sobre os royalties pagos ao exterior relativos à licença de uso de software. Contudo incide a contribuição no pagamento a pessoa física ou jurídica residente ou domiciliada no exterior pela prestação de serviços, como os de assistência técnica e de instalação, implementação e execução do software, mesmo que vinculada ao contrato de licença de uso. Neste caso, deve ser feita a discriminação dos valores correspondentes à licença e aos serviços."
}

Não obstante isso, dentro da própria Secretaria da Receita Federal não há posição pacífica quanto ao enquadramento da licença de uso de software e quanto à qualificação do respectivo pagamento. Já houve até a oposição de recurso objetivando a uniformização dos entendimentos, o que acabou dando ensejo à Solução de Divergência expedida pela COSIT, que decidiu que o pagamento pela citada licença configura royalty não tributável pelo PIS/COFINS, mas que os serviços devem ser tributados:

"Solução de Consulta n $11 / 11$, da COSIT
ASSUNTO: Contribuição para o Financiamento da Seguridade Social - Cofins
EMENTA: Royalties. Não haverá incidência da Cofins-Importação sobre o valor
pago a título de Royalties, se o contrato discriminar os valores dos Royalties, dos
serviços técnicos e da assistência técnica de forma individualizada. Neste caso, a
contribuição sobre a importação incidirá apenas sobre os valores dos serviços
conexos contratados. Porém, se o contrato não for suficientemente claro para 
individualizar estes componentes, o valor total deverá ser considerado referente a serviços e sofrer a incidência da mencionada contribuição."

Realmente, a incidência do PIS e da COFINS sobre a remuneração enviada ao exterior como contraprestação pela licença de uso de programa de computador é flagrantemente ilegal e inconstitucional, pois consoante já exposto, a licença nada mais é que uma autorização para o uso de obra intelectual protegida pelo direito autoral e que não guarda identidade com os fatos geradores das contribuições.

Vale lembrar que o fato gerador marcado pela entrada de bens estrangeiros no território nacional (e até a inclusão do ICMS correspondente na base de cálculo das contribuições) pressupõe a existência de desembaraço aduaneiro, mas os bens intangíveis não são desembaraçados.

A Lei $\mathrm{n}^{\circ}$ 10.865/04 expressamente estabelece que a materialidade para a incidência das contribuições são os serviços prestados por pessoa física ou jurídica, o que nos permite afirmar que tais serviços para assim serem considerados devem consistir em uma obrigação de fazer e a licença de uso constitui uma obrigação de dar. A nosso ver, não pairam dúvidas quanto a isso.

Em relação aos programas de computador desenvolvidos "sob encomenda" que certamente ensejam uma prestação de serviço (obrigação de fazer), mas que a depender da forma de contratação, podem ou não envolver a concessão de licença de uso, muito se discute acerca dos serviços executados no exterior, cujo resultado se verifique no País por se tratar de materialidade eleita para a incidência das contribuições. A outra hipótese de serviços executados no País por prestador residente ou domiciliado no exterior não gera questionamentos ante a facilidade de se verificar a configuração da importação de serviços.

Em outras palavras, nos termos do art. $1^{\circ}$, da Lei $\mathrm{n}^{\mathrm{o}} 10.865 / 04$, a incidência do PIS/COFINS na importação de serviços requer sejam estes executados por um não residente no Brasil ou no exterior, mas neste último caso o seu resultado deve ocorrer aqui.

Traçando um paralelo com o art. $1^{\circ}, \S 1^{\circ}$, da LC $n^{\circ} 116 / 03$ que prevê que o ISS incide sobre o serviço proveniente do exterior do País ou cuja prestação se tenha iniciado no exterior do País, a Lei $\mathrm{n}^{\circ} 10.865 / 04$ é mais clara ao considerar como tributáveis (a 
prestação de serviços/obrigação de fazer) os serviços executados no Brasil ou executados no exterior, mas desde que o seu resultado aqui se verifique.

Entretanto, a lei é obscura quanto à definição do resultado da prestação de serviço. A doutrina não é uníssona a respeito. Há quem diga que o mencionado resultado deve ser interpretado como o resultado-consumação, outros sustentam tratar-se de resultadoutilidade.

Na definição dada por Sérgio André Rocha ${ }^{452}$, o resultado-consumação deve ser entendido como a consumação material da prestação de serviços pelo prestador. Ao sustentar tal posição, o pesquisador relata um exemplo de uma empresa brasileira que contrata uma empresa francesa para prestar serviços de reparos de equipamentos que serão executados no exterior, muito embora os equipamentos sejam posteriormente enviados e utilizados aqui, e diz: "caso se entenda que o resultado do serviço de reparo consiste na consumação material de tal atividade, concretizada no fato de que o equipamento que antes estava com defeito encontra-se novamente operacional, será possível sustentar que neste caso não há que se cogitar da incidência das contribuições" (tanto o serviço quanto o seu resultado ocorreu no exterior).

Alberto Macedo ${ }^{453}$, por sua vez, discorda e defende o resultado-utilidade assim entendido como a utilidade gerada em decorrência da prestação de serviços em favor de terceiro (o contratante), o que significa dizer que mesmo sendo totalmente executado no exterior, se o resultado do serviço ocorrer no Brasil como, por exemplo, se a fruição do serviço prestado for aqui vislumbrada, estará cofigurada a importação de serviços tributável pelo PIS/COFINS-importação.

Em que pese as divergentes opiniões acerca da questão e em razão do PIS e da COFINS incidentes na importação de bens/serviços serem relativamente recentes, não há um consenso quer na doutrina, quer na jurisprudência, quer, ainda, dentro da própria Secretaria da Receita Federal.

\footnotetext{
${ }^{452} \mathrm{O}$ resultado do serviço como elemento da regra de incidência do PIS/COFINS-Importação e da regra exonerativa do ISS sobre exportações, Revista Dialética de Direito Tributário, $\mathrm{n}^{\circ}$ 155, São Paulo: Dialética, 2008 p. 112.

${ }^{453}$ ISS e PIS-COFINS-Importação, op. cit., p. 19/21.
} 
Contudo, em caso envolvendo o ISS relativo à exportação de serviços, o STJ (RESP n $\left.{ }^{\circ} 831.124\right)$ adotou o "resultado-consumação" para negar ao contribuinte o direito à desoneração dos serviços prestados a clientes residentes/domiciliados no exterior (exportações) por entender que a execução dos serviços em território nacional, independentemente de a fruição/utilidade dos serviços ocorrer no exterior, afasta a configuração da exportação de serviços.

\subsection{Contribuição de Intervenção no Domínio Econômico instituída pela Lei $n^{0} \mathbf{1 0 . 1 6 8 / 0 0}$}

A Contribuição de Intervenção no Domínio Econômico está expressamente prevista no art. 149, da Constituição Federal ${ }^{454}$, segundo o qual compete exclusivamente à União instituir contribuição interventiva para atuar em determinada área econômica e desde que observado os artigos 146, III $^{455}, 150$, I e III e $195, \S^{\circ}$, todos da Constituição.

Andrei Pitten Velloso ${ }^{456}$ assevera que as contribuições interventivas são instrumentos destinados a propiciar ou facilitar a intervenção, por parte da União, no domínio econômico, e que são tributos especiais vocacionados à promoção de fins determinados.

454 “Art. 149. Compete exclusivamente à União instituir contribuições sociais, de intervenção no domínio econômico e de interesse das categorias profissionais ou econômicas, como instrumento de sua atuação nas respectivas áreas, observado o disposto nos arts. 146, III, e 150, I e III, e sem prejuízo do previsto no art. $195, \S 6^{\circ}$, relativamente às contribuições a que alude o dispositivo.

$\S 1^{\circ}$ Os Estados, o Distrito Federal e os Municípios instituirão contribuição, cobrada de seus servidores, para o custeio, em benefício destes, do regime previdenciário de que trata o art. 40, cuja alíquota não será inferior à da contribuição dos servidores titulares de cargos efetivos da União.

$\S 2^{\circ}$ As contribuições sociais e de intervenção no domínio econômico de que trata o caput deste artigo:

I - não incidirão sobre as receitas decorrentes de exportação;

II - incidirão também sobre a importação de produtos estrangeiros ou serviços;

III - poderão ter alíquotas:

a) ad valorem, tendo por base o faturamento, a receita bruta ou o valor da operação e, no caso de importação, o valor aduaneiro;

b) específica, tendo por base a unidade de medida adotada.

$\S 3^{\circ}$ A pessoa natural destinatária das operações de importação poderá ser equiparada a pessoa jurídica, na forma da lei.

$\S 4^{\circ}$ A lei definirá as hipóteses em que as contribuições incidirão uma única vez."

455 É digno de nota que, ao julgar o RE $n^{\circ} 138.824 / \mathrm{CE}$, o STF decidiu que as normas contidas no CTN satisfazem a exigência da lei complementar, de modo que as contribuições em geral podem ser instituídas por lei ordinária. Especificamente em relação às de intervenção no domínio econômico, a Suprema Corte já se posicionou pela legitimidade de lei ordinária instituir CIDE, tal qual ocorreu com o Adicional de Tarifa Portuária-ATP (RE nº 218.061/SP).

456 Contribuições - Teoria geral - Contribuições em espécies, Porto Alegre: Livraria do Advogado, 2010, p. 242. 
Segundo ele, a instituição de tais contribuições deve observar os seguintes requisitos: (a) observância das limitações gerais ao poder de tributar; (b) existência de competência impositiva; (c) busca da finalidade especificada pela norma atributiva de competência; (d) necessidade; (e) referibilidade; (f) atividade passível de ser financiada mediante a cobrança da CIDE; (g) caráter setorial; e, (h) observância dos princípios gerais da ordem econômica. ${ }^{457}$

Embasado nas lições de Marco Aurélio Greco, Velloso ${ }^{458}$ também pontua ser indispensável haver um liame entre a intervenção em determinado setor específico e as atividades de certo grupo econômico (referibilidade), bem como que a CIDE não pode ser instituída em relação ao domínio econômico como um todo, inibindo o desenvolvimento de certa atividade ou com o escopo de torná-la proibitiva ou pouco atrativa para a iniciativa privada, sob pena de malferir a garantia fundamental à livre iniciativa (art. 170, da CF).

A expressão referibilidade possui várias acepções, podendo ser entendida como benefício econômico ou responsabilidade por despesas específicas (referibilidade como benefício), bem como o liame entre a finalidade da contribuição e as atividades ou interesses dos sujeitos passivos (referibilidade como pertinência). ${ }^{459}$

Para Andrei Pitten Velloso ${ }^{460}$ a referibilidade entendida como benefício econômico não constitui elemento conceitual ou pressuposto de validade das contribuições especiais, como a CIDE. O doutrinador defende que o "liame referido", assim entendido como mero fato de os sujeitos passivos atuarem no segmento objeto da intervenção, este sim indispensável, não deve ser confundido com benefício econômico e que não é necessário que os sujeitos passivos sejam beneficiados pela atividade interventiva.

Tal entendimento não é pacífico. Sacha Calmon Navarro Coêlho e André Mendes Moreira $^{461}$ defendem opinião divergente pautada na referibilidade assim entendida como a correlação lógica entre os pagantes e o benefício proporcionado pela atuação estatal que

457 Contribuições, op. cit., p. 246.

458 Contribuições, op. cit.,p. 247/248.

459 Cf. PAULSEN, Leandro e VELLOSO, Andrei Pitten, Contribuições, op. cit., p. 54/56.

460 Contribuições, op. cit., p. 54/56.

461 Inconstitucionalidades da contribuição de intervenção no domínio econômico ao exterior - CIDE royalties, Revista Dialética de Direito Tributário, no 89, São Paulo: Dialética, 2003, p. 74. 
deu ensejo à exigência da contribuição. Para eles, a intervenção estatal deve beneficiar os contribuintes da exação de modo direto.

Em se tratando de espécie tributária vinculada a uma atuação estatal, acreditamos que a contribuição interventiva, além da referibilidade no sentido proposto por Velloso (nexo temático entre os sujeitos passivos e a finalidade almejada pela CIDE), é necessário haver a correlação lógica acima mencionada, sob e pena de converter-se a contribuição em tributo desvinculado (imposto) de qualquer prestação estatal.

Entretanto, o STF já afastou a necessidade de as contribuições interventivas proporcionarem benefícios aos contribuintes pagantes ao julgar constitucional a contribuição ao SEBRAE (RE $n^{\circ}$ 401.823), assim como o STJ (RESP n ${ }^{\circ} 770.451$ ) afastou a necessidade de haver "liame referido" entre sujeitos passivos (que deveriam atuar no segmento sob intervenção) e o setor objeto da contribuição ao INCRA, tida como CIDE.

$\mathrm{Na}$ nossa opinião, a finalidade da CIDE é o que determina e condiciona o seu espectro de incidência, motivo pelo qual não admitimos a possibilidade de não haver, ao menos, referibilidade entre os sujeitos passivos e a finalidade da contribuição, pois uma vez eleita como instrumento de intervenção em determinada seara, o gravame não pode alcançar bens, pessoas ou relações que não digam respeito à área que requer reprimenda ou incentivo estatal.

Com fundamento no art. 149, da CF, a Lei $\mathrm{n}^{\mathrm{o}} 10.168 / 00^{462}$ instituiu a CIDE como instrumento de intervenção na seara da Ciência e da Tecnologia (art. $218^{463}$, que inicia o

462 “Art. 1ํㅡㄹ Fica instituído o Programa de Estímulo à Interação Universidade-Empresa para o Apoio à Inovação, cujo objetivo principal é estimular o desenvolvimento tecnológico brasileiro, mediante programas de pesquisa científica e tecnológica cooperativa entre universidades, centros de pesquisa e o setor produtivo.

Art. $2^{\mathrm{O}}$ Para fins de atendimento ao Programa de que trata o artigo anterior, fica instituída contribuição de intervenção no domínio econômico, devida pela pessoa jurídica detentora de licença de uso ou adquirente de conhecimentos tecnológicos, bem como aquela signatária de contratos que impliquem transferência de tecnologia, firmados com residentes ou domiciliados no exterior.

$\S 1^{\circ}$ Consideram-se, para fins desta Lei, contratos de transferência de tecnologia os relativos à exploração de patentes ou de uso de marcas e os de fornecimento de tecnologia e prestação de assistência técnica. $(\ldots) "$

463 “Art. 218. O Estado promoverá e incentivará o desenvolvimento científico, a pesquisa e a capacitação tecnológicas.

$\S 1^{\circ}$ - A pesquisa científica básica receberá tratamento prioritário do Estado, tendo em vista o bem público e o progresso das ciências. 
Capítulo IV, da CF), exigida à alíquota de 10\%, para custear o Programa de Estímulo à Interação Universidade-Empresa para o apoio à inovação com o intuito de estimular o desenvolvimento tecnológico brasileiro, mediante programas de pesquisa científica e tecnológica cooperativa entre universidades, centros de pesquisa e o setor produtivo.

A mencionada contribuição foi concebida para proporcionar recursos a serem destinados ao Fundo Nacional de Desenvolvimento Científico e Tecnológico - FNDCT ${ }^{464}$ e considerando que a intervenção no domínio econômico se dá mediante o financiamento de pesquisas tecnológicas, o legislador escolheu como sujeitos passivos os detentores de licença de uso ou adquirentes de conhecimentos tecnológicos e os que contratam a transferência de tecnologia ${ }^{465}$ com residentes e domiciliados no exterior.

A nosso ver, é difícil compreender a relação entre o desenvolvimento tecnológico brasileiro e os contratos de transferência de tecnologia firmados por particulares integrantes dos mais diversos segmentos econômicos, pois a referibilidade neste caso não se aperfeiçoa adequadamente. A despeito de o setor sob intervenção ser o da ciência/tecnologia, os destinatários da lei instituidora da CIDE não necessariamente pertencem a segmento dedicado à tecnologia.

Todavia, tal qual sustenta Marco Aurélio Greco ${ }^{466}$, ao menos se pode dizer que "a tecnologia foi qualificada como fim a ser buscado e a pesquisa científica e tecnológica como meio para alcançá-lo", o que afasta qualquer tentativa de se tributar, por exemplo, qualquer espécie de licença de uso, pois “é indispensável que se examine o objeto a que se

$\S 2^{\circ}$ - A pesquisa tecnológica voltar-se-á preponderantemente para a solução dos problemas brasileiros e para o desenvolvimento do sistema produtivo nacional e regional.

$\S 3^{\circ}$ - O Estado apoiará a formação de recursos humanos nas áreas de ciência, pesquisa e tecnologia, e concederá aos que delas se ocupem meios e condições especiais de trabalho.

$\S 4^{\circ}$ - A lei apoiará e estimulará as empresas que invistam em pesquisa, criação de tecnologia adequada ao País, formação e aperfeiçoamento de seus recursos humanos e que pratiquem sistemas de remuneração que assegurem ao empregado, desvinculada do salário, participação nos ganhos econômicos resultantes da produtividade de seu trabalho.

$\S 5^{\circ}$ - É facultado aos Estados e ao Distrito Federal vincular parcela de sua receita orçamentária a entidades públicas de fomento ao ensino e à pesquisa científica e tecnológica."

${ }^{464}$ Sacha Calmon Navarro Coelho e André Mendes Moreira sustentam que o FNDCT, criado pelo DL $\mathrm{n}^{\circ}$ 719/69, foi extinto quer em razão de não ter sido ratificado pelo Congresso Nacional no prazo de 2 anos contados da promulgação da Constituição, quer em razão de ter sido restabelecido fora do prazo por lei ordinária (Lei $\mathrm{n}^{\circ}$ 8.172/91) quando deveria ter sido por LC (Inconstitucionalidades, op. cit., p. 81).

465 De acordo com a citada lei, os contratos que ensejam a transferência de tecnologia são os de exploração de patentes ou de uso de marcas e os de fornecimento de tecnologia e prestação de assistência técnica.

466 Contribuição de intervenção no domínio econômico sobre "royalties", Revista Dialética de Direito Tributário, no 99, São Paulo: Dialética, 2003, p. 137 e 141. 
refere, o qual deve ser, necessariamente, vinculado à tecnologia, pois esta é a ratio da lei que está em sintonia com a ratio da matriz constitucional."

Em 20.12.2001, foi publicada a Lei ${ }^{\circ} 10.332$ que, dentre outras alterações, ampliou a hipótese de incidência da contribuição (art. $2^{\circ}, \S 2^{\circ}$, da Lei ${ }^{\circ} 10.168 / 00^{467}$ ) para alcançar as pessoas jurídicas que contratam serviços técnicos e de assistência administrativa e semelhantes prestados por residentes ou domiciliados no exterior, bem como as pessoas jurídicas que remetem royalties, a qualquer título, a beneficiários residentes ou domiciliados no exterior.

Ao promover a alteração supra, o legislador deturpou a função e requisitos até aqui expostos para a instituição de uma CIDE, pois a contribuição passou a, equivocadamente, incidir sobre praticamente qualquer pagamento remetido ao exterior como contraprestação pela prestação de serviços, independentemente de envolver ou não a transferência de tecnologia.

Aliás, a menção quanto à incidência da contribuição sobre royalties a qualquer título, nos faz pensar que o legislador realmente subverteu todo o sistema para fazê-la incidir inclusive sobre royalties que não correspondam à contraprestação de transferência de tecnologia.

Alberto Xavier ${ }^{468}$ faz acertada colocação quanto à adequada interpretação da expressão royalties a qualquer título. Para ele, tais royalties são os rendimentos que remuneram direitos de pesquisa e de uso ou exploração de invenções, processos e fórmulas de fabricação, com natureza científica e tecnológica.

Neste sentido, o Professor Gerd Willi Rothmann ${ }^{469}$ está coberto de razão ao sustentar que a CIDE-tecnologia não passa de um imposto disfarçado, que possui fins meramente arrecadatórios e que é utilizada para compensar perda de receita. Tal posição é

\footnotetext{
467 “Art. $2^{\circ}-(\ldots)$

$\S 2^{\circ}$ A partir de $1^{\circ}$ de janeiro de 2002 , a contribuição de que trata o caput deste artigo passa a ser devida também pelas pessoas jurídicas signatárias de contratos que tenham por objeto serviços técnicos e de assistência administrativa e semelhantes a serem prestados por residentes ou domiciliados no exterior, bem assim pelas pessoas jurídicas que pagarem, creditarem, entregarem, empregarem ou remeterem royalties, a qualquer título, a beneficiários residentes ou domiciliados no exterior."

468 Direito Tributário Internacional do Brasil, $7^{\text {a }}$ Ed., Rio de Janeiro: Forense, 2010, p. 510.

469 Inconstitucionalidade, op. cit., p. 127.
} 
compartilhada por Marcos André Vinhas Catão ${ }^{470}$, para quem a contribuição é um tributo sobre a importação de serviços e que sequer poderia ser exigida em conjunto com o PIS/COFINS-importação, em face da identidade de materialidades e por ofender o princípio da não-discriminação previsto no art. $2^{\circ}$ do $\operatorname{GATS}^{471}$ (do qual o Brasil é signatário), aplicável ao comércio internacional, já que os serviços prestados por residentes nacionais não estão sujeitos à contribuição interventiva.

Ao se distanciar da finalidade inicialmente almejada, onerando atividades que não envolvem transferência de tecnologia, a contribuição interventiva não deixa de ser um adicional do IRRF, dado que nas situações em que a CIDE é exigida (10\%), o imposto é exigido à alíquota de $15 \%{ }^{472}$, contra os $25 \%$ exigidos em situações em que a contribuição não é cobrada. Trata-se de adicional inconstitucional, diga-se de passagem, pois a sua receita está vinculada a determinado fundo em total afronta ao art. 167, IV, da CF.

Consoante se verifica, a redução da alíquota do IRRF para $15 \%$ a partir da cobrança da contribuição interventiva reflete diretamente no fundo de participação dos Estados e Municípios e, consequentemente, no pacto federativo, já que se reduziram as receitas a serem partilhadas.

Por muito tempo as empresas adquirentes de licenças de uso de software advindas do exterior sofreram com a insegurança jurídica causada pela falta de bom senso da Autoridade Fiscal Administrativa ${ }^{473}$ que não vislumbrava na finalidade da CIDE uma

${ }^{470}$ Incompatibilidade da Contribuição de Intervenção no Domínio Econômico CIDE-Tecnologia (Lei $n^{\circ}$ 10.168/00), a partir da Instituição do PIS/COFINS - Importação/Serviços (Lei n 10.865/04). Violação das Regras do GATT e GATS, Revista Dialética de Direito Tributário, $\mathrm{n}^{\circ} 115$, São Paulo: Dialética, 2005, p. 90/94.

471 "Os produtos do território de qualquer parte contratante, importados no território de qualquer parte contratante, não estarão sujeitos, direta ou indiretamente, a impostos ou outras imposições internas, qualquer que seja a sua espécie, superiores aos aplicados, direta ou indiretamente, aos produtos nacionais similares (...)."

472 Antes mesmo do advento da Lei $n^{\circ} 10.168 / 00$, a MP n 2.062-60, e demais reedições, que aumentou a alíquota do IRRF para $25 \%$, já previa a possibilidade da sua redução para $15 \%$ quando fosse instituída contribuição de intervenção no domínio econômico (10\%).

473 "Solução de Consulta n $\mathrm{n}^{\mathrm{O}} 128 / 02$

ASSUNTO: Outros Tributos ou Contribuições

EMENTA: CONTRIBUIÇÃO DE INTERVENÇÃO DE DOMÍNIO ECONÔMICO (CIDE) INCIDÊNCIA LICENÇA DE USO DE SOFTWARE. Os valores pagos, creditados, entregues, empregados ou remetidos, a cada mês, a residente ou domiciliado no exterior, a título de royalties, em virtude de contrato de licenciamento de software, sofrem a incidência da Contribuição de Intervenção no Domínio Econômico, instituída pelo art. $2^{\circ}$ da Lei $n^{\circ} 10.168$, de 2000, por caracterizarem pagamentos por "licença de uso". Em conseqüência, estão sujeitos, como regra, ao pagamento do IRRF e da CIDE, às alíquotas de $15 \%$ e $10 \%$, respectivamente. ASSISTÊNCIA TÉCNICA, SERVIÇOS TÉCNICOS E DE 
limitação quanto ao seu sentido e alcance e exige a contribuição mesmo em situações sem qualquer transferência de tecnologia.

Conforme anteriormente esmiuçado, a licença de uso de software nada mais é que a autorização para a utilização de obra intelectual protegida pelo direito autoral, de modo que não se pode confundir o produto do intelecto humano com a tecnologia que o autor utilizou para a sua confecção.

Marco Aurélio Grecco bem explicita que tecnologia e obra estão em planos diferentes, que assumem a condição de objetos distintos ao serem tomados pelas normas jurídicas como referencial de suas disposições e que, principalmente, existem contratos que têm por objeto a obra e contratos que têm por objeto a tecnologia, mas quando se adquire um, nem por isso se adquire o outro. Confira-se:

\footnotetext{
"De fato, quem adquire a tecnologia passa a ter condições de produzir determinada obra; tem a potencialidade de fazê-lo, potencialidade que poderá ou não se concretizar.

Por outro lado, quem adquire a obra estará fruindo das utilidades e qualidades da obra em si e não tem - em princípio - acesso à tecnologia que levou à sua produção.

Assim, por exemplo, quem adquire um automóvel (= produto) dele extrai as utilidades de transporte, conforto e segurança, mas não tem acesso à tecnologia utilizada para fazer com que os freios $\mathrm{ABS}$ funcionem ou os sensores do air-bag sejam acionados.

(...)

Não há transferência presumida. Ou o objeto do contrato é claramente a própria tecnologia ou não se pode falar em negócio jurídico que sobre ela esteja dispondo. Não é por adquirir um automóvel com ABS e air-bag que alguém estará presumidamente adquirindo a respectiva tecnologia." ${ }^{474}$
}

Aproximando o exemplo acima da licença de uso de programas de computador é fácil vislumbrar que ao concedê-la o autor não está a fornecer o segredo sobre como o

\footnotetext{
ASSISTÊNCIA ADMINISTRATIVA E SEMELHANTES. Os valores pagos, creditados, entregues, empregados ou remetidos por pessoa jurídica sediada no País a residentes ou domiciliados no exterior, em contrapartida pela prestação dos serviços acima referidos, com ou sem transferência de tecnologia, estão sujeitos ao pagamento da CIDE, à alíquota de 10\% (dez por cento), e do IRRF à alíquota de $15 \%$."

"Solução de Consulta n $\mathrm{n}^{\mathrm{O}} 1 / 06$

ASSUNTO: Outros Tributos ou Contribuições

EMENTA: CIDE. LICENÇA DE USO DE PROGRAMAS DE COMPUTADOR (SOFTWARE) INCIDÊNCIA. A Contribuição de Intervenção no Domínio Econômico (Cide) instituída pelo art. $2^{\circ}$ da Lei $\mathrm{n}^{\circ} 10.168$, de 2000, para atendimento ao Programa de Estímulo à Interação Universidade-Empresa para o Apoio à Inovação, incide sobre as importâncias pagas, creditadas, entregues, empregadas ou remetidas a residentes ou domiciliados no exterior a título de remuneração decorrente de licença de uso de programas de computador (software), independentemente de os contratos relativos a tal licença estarem atrelados à transferência de tecnologia."

474 Contribuição, op. cit., p. 139.
} 
software foi concebido, pois se assim fosse, não se trataria de mera licença, mas de cessão (integral) de direitos patrimoniais de autor ("compra e venda"), o que pressuporia a entrega da documentação completa, em especial do código-fonte comentado, memorial descritivo, especificações funcionais internas, diagramas, fluxogramas e outros dados técnicos necessários à absorção da tecnologia.

Em outras palavras, a partir da obtenção da licença de uso o licenciado apenas consegue utilizar o programa (fazer uso do produto), sem jamais ter acesso ao seu núcleo (à sua tecnologia) o que, consequentemente, o impede de produzir o mesmo produto ou de agregar ao seu acervo intelectual conhecimento tecnológico novo. ${ }^{475}$

Em face dos diversos questionamentos gerados em torno da incidência da CIDE sobre os pagamentos remetidos ao exterior a título de contraprestação pelas licenças de uso de software, foi necessário que o legislador esclarecesse que a contribuição não incide sobre remuneração pela licença de uso de programa de computador, salvo quando houver a transferência da correspondente tecnologia. Foi o que fez a Lei $n^{\circ} 11.452 / 07$ ao incluir o $\S 1^{\circ}$-A, no art. $2^{\circ}$, da Lei $n^{\circ} 10.168 / 00^{476}$.

Todavia, não obstante a alteração legal (que garante maior segurança jurídica aos contribuintes), a exigência da contribuição mesmo em situações envolvendo a licença de uso sem a transferência de tecnologia não deixou de existir.

A Autoridade Fiscal Administrativa, em situações de menor número, é verdade, opina pela incidência da contribuição sob o argumento de que os pagamentos pelas licenças configuram royalties, materialidade que é alcançada pela CIDE. ${ }^{477}$

475 Cf. GRECO, Marco Aurélio, Contribuição, op. cit., p. 137 e 141.

476 "Art. $2^{\circ}-(\ldots)$

$\S 1^{\circ}$-A. A contribuição de que trata este artigo não incide sobre a remuneração pela licença de uso ou de direitos de comercialização ou distribuição de programa de computador, salvo quando envolverem a transferência da correspondente tecnologia."

477 “Solução de Consulta no 31/07, da Superintendência Regional da Receita Federal da $8^{\text {a }}$ Região Fiscal ASSUNTO: Outros Tributos ou Contribuições

EMENTA: Contribuição de Intervenção no Domínio Econômico (Cide). INCIDÊNCIA Pelo fato de a remuneração dos direitos autorais ser considerada "royalties", a empresa que pagar, creditar, entregar, empregar, ou remeter importâncias ao exterior a esse título, pela cessão ou licença de uso de software (CD-ROM e DVD), está sujeita ao pagamento da Contribuição de Intervenção no Domínio Econômico instituída pela Lei ${ }^{\circ} 10.168$, de 2000. CRÉDITO A partir de 28 de julho de 2001 (vigência da Medida Provisória n 2.159-69, de 27 de julho de 2001), o crédito, passível de dedução em operações posteriores 
Entretanto, ainda que os royalties a qualquer título configurem hipótese de incidência da contribuição interventiva (nos termos do art. $2^{\circ}, \S 2^{\circ}$, da Lei $n^{\circ} 10.168 / 00$ ), o legislador fez da remuneração pela licença de uso de software (sem transferência de tecnologia) uma hipótese de não-incidência da norma.

Alberto Xavier ${ }^{478}$ vai além e argumenta que "o mero fato de o rendimento pago em contrapartida de um direito autoral se qualificar como royalty para fins da legislação do imposto de renda não é, pois, suficiente para que sobre tais rendimentos incida a CIDEremessas, uma vez que os negócios tendo por objeto direitos autorais não têm conteúdo tecnológico, nem implicam a transferência de tecnologia”.

No ordenamento jurídico brasileiro, o royalty é rendimento que representa a remuneração pelo uso, fruição, exploração de direitos vegetais, minerais, industriais e intelectuais, conforme dispõe o art. 22, da Lei $n^{\circ} 4.506 / 64^{479}$ (a mesma disposição está reproduzida no art. 52, do RIR/99 e na Instrução Normativa SRF nº 208/02). Diferencia-se dos aluguéis, que representam a retribuição do capital aplicado em bens corpóreos, e dos juros, que exprimem a contrapartida do capital financeiro. ${ }^{480}$

de mesma natureza, é concedido sobre a Contribuição de Intervenção no Domínio Econômico incidente sobre royalties referentes a contratos de exploração de patentes e de uso de marca."

"Solução de Consulta n ${ }^{\circ}$ 236/07, da Superintendência Regional da Receita Federal da 7 Região Fiscal

ASSUNTO: Contribuição de Intervenção no Domínio Econômico - CIDE EMENTA: PROGRAMAS DE COMPUTADOR. LICENÇA DE USO. IMPORTAÇÃO DE SOFTWARE. Os valores pagos, creditados, entregues, empregados ou remetidos a beneficiário residente ou domiciliado no exterior a título de remuneração de contrato de licença de uso de programas de computador - softwares para uso próprio - independentemente da terminologia usada poder ser a de royalties ou não, ficam sujeitos ao pagamento da referida contribuição, calculada à alíquota de $10 \%$ (dez por cento), sendo irrelevantes que o contrato não tenha sido averbado no INPI e registrado no Bacen. Fundamentação Legal: Lei $n^{\circ} 10.168$, de 29 de dezembro de 2000, com a redação dada pela Lei $n^{\circ}$ 10.332 , de 19 de dezembro de 2001, art. $2^{\circ} . "$

478 Direito Tributário Internacional do Brasil, $7^{\mathrm{a}}$ Ed., Rio de Janeiro: Forense, 2010, p. 511.

479 “Art. 22. Serão classificados como 'royalties' os rendimentos de qualquer espécie decorrentes do uso, fruição, exploração de direitos, tais como:

a) direito de colhêr ou extrair recursos vegetais, inclusive florestais;

b) direito de pesquisar e extrair recursos minerais;

c) uso ou exploração de invenções, processos e fórmulas de fabricação e de marcas de indústria e comércio;

d) exploração de direitos autorais, salvo quando percebidos pelo autor ou criador do bem ou obra.

Parágrafo único. Os juros de mora e quaisquer outras compensações pelo atraso no pagamento dos 'royalties' acompanharão a classificação destes."

480 Cf. XAVIER, Alberto, Direito, op. cit., p. 617. 
Contudo, o art. 22, da Lei $\mathrm{n}^{\circ}$ expressamente excepciona do conceito de royalty a remuneração paga diretamente ao autor da obra protegida pelo direito autoral. ${ }^{481}$

Luís Eduardo Schoueri e Guilherme Cezaroti ${ }^{482}$ elucidam que os royalties no direito tributário internacional, independem de serem pagos diretamente ao autor da obra e que nos termos do art. 12 do modelo de Convenção contra a bitributação da Organização para a Cooperação e Desenvolvimento Econômico-OCDE constituem remunerações de qualquer natureza pagas pelo uso ou pela concessão do uso de: (i) direitos de autor sobre obras literárias, artísticas ou científicas, de patentes; (ii) marcas de indústria ou de comércio, desenhos ou modelos, planos, fórmulas ou processos secretos; (iii) equipamentos industriais, comerciais ou científicos; e (iv) informações correspondentes à experiência adquirida no setor industrial, comercial ou científico.

Embasados em definições de José Luiz Bulhões Pedreira, Schoueri e Cezaroti ${ }^{483}$ apontam que a enunciação do art. 22, da Lei n ${ }^{\circ} 4.506 / 64$ é meramente exemplificativa e não exaustiva, já que, para eles, royalty é qualquer rendimento decorrente da exploração de direitos, mesmo que não expressamente mencionado na lei.

Considerando que a Lei $n^{\circ} 10.168 / 00$, instituidora da contribuição interventiva, não traz nenhuma definição quanto aos royalties, a definição dada pela Lei $n^{\circ} 4.506 / 64$, que cuida do imposto de renda, é plenamente aplicável à CIDE.

Assim, em caso de a remuneração pelo uso de direitos autorais (licença de uso) ser paga diretamente ao autor do software (obra intelectual protegida pelo direito autoral), como comumente ocorre, a legislação brasileira do imposto de renda expressamente exclui tal rendimento do conceito de royalty, o que também afasta a incidência da CIDEtecnologia.

481 É digno de nota o raciocínio de Alberto Xavier, segundo o qual não configura royalty a remuneração pela cessão do próprio direito de propriedade intelectual representado pelo software, caso em que o preço da cessão tem natureza de elemento para o cômputo de um ganho de capital ou de "lucro da empresa" (Direito, op. cit., p. 629).

482 A Cide-royalties e as remessas por licença de distribuição e comercialização de programas de computador, Revista Dialética de Direito Tributário, no 130, São Paulo: Dialética, 2006, p. 45.

${ }^{483}$ A Cide-royalties, op. cit.,p. 46. 


\subsection{Imposto sobre a Renda Retido na Fonte - IRRF}

Não é de hoje que o imposto de renda incide sobre os rendimentos pagos por fontes situadas no Brasil a residentes ou domiciliados no exterior.

Sob a égide da Constituição 1937, foi editado o Decreto-lei $\mathrm{n}^{\circ}$ 5.844/43 que dispunha sobre a cobrança e fiscalização do imposto de renda e cujo art. $97^{484}$ previa que os rendimentos das pessoas físicas ou jurídicas residentes ou domiciliadas no estrangeiro seriam tributados à razão de $10 \%$.

Posteriormente, o Decreto $\mathrm{n}^{\mathrm{o}} 58.400 / 66$ aprovou o regulamento do imposto de renda e regulamentou o citado art. 97 , por meio do seu art. $33^{485}$ que, expressamente, previa que os rendimentos provenientes de fontes situadas no Brasil, percebidos por pessoas físicas e jurídicas residentes ou domiciliadas no estrangeiro estariam sujeitos ao imposto.

Tais dispositivos legais causaram enorme polêmica notadamente com relação aos efeitos extraterritoriais perpetrados, pois a Constituição de 1946 que lhes dava fundamento de validade não contemplava o princípio da universalidade da renda.

Após muito debater, o Supremo Tribunal Federal decidiu, reiteradas vezes ${ }^{486}$, que as normas legais acima mencionadas não eram o bastante para legitimar a incidência do imposto de renda sobre os rendimentos remetidos a residentes ou domiciliados no exterior, principalmente no tocante à remuneração de prestação de serviços técnicos executados no exterior por estrangeiros.

Em alguns casos como, por exemplo, o Recurso Extraordinário no 77.793 , o então Ministro Moacir Catunda negou provimento ao recurso da União por entender que "o reembolso da despesa com o serviço executado totalmente no exterior, por empresa

484 “Art. 97. Sofrerão o desconto do imposto à razão da taxa de 10\% os rendimentos percebidos:

a) pelas pessoas físicas ou jurídicas residentes ou domiciliadas no estrangeiro;”

485 “Art. 33. Estão sujeitos ao impôsto de renda, de acôrdo com as disposições dos artigos 292 a 300 , os rendimentos provenientes de fontes situadas no País, quando percebidos:

a) pelas pessoas físicas ou jurídicas residentes ou domiciliadas no estrangeiro (Decreto-Lei $\mathrm{n}^{\circ} 5.844$, artigo 97, "a");"

486 Vide Recursos Extraordinários nºs 72.190, 69.513, 77.773, 77.920, 78.479, 80.622 e 81.945. 
sediada lá, constituía receita bruta da entidade credora da quantia remetida, e não lucro ou rendimento tributável no Brasil, na forma prevista no art. 33 e $292^{487}$ a $300^{488}$, do Regulamento do Imposto de Renda, de modo que a exigência mostrava-se desprovida de amparo legal".

Com fundamento no art. $9^{\circ}, \S 2^{\circ}$, da Lei de Introdução às Normas do Direito Brasileiro $^{489}$ (ex Lei de Introdução ao Código Civil), segundo o qual a obrigação resultante do contrato reputa-se constituída no lugar em que residir o proponente, o STF declarou a não incidência do imposto de renda retido na fonte com base no Decreto $\mathrm{n}^{\circ}$ 58.400/66 sobre os pagamentos remetidos ao exterior para fazer frente aos serviços contratados e realizados no exterior.

Aliás, quando do julgamento do principal caso acerca da matéria ( $\left.\operatorname{RE~} n^{\circ} 72.190^{490}\right)$, o STF também se baseou no conteúdo da Portaria do Ministro de Estado da Fazenda ${ }^{\circ}$ 184/66, que atuava como excludente da incidência, desonerava da tributação pelo imposto de renda os rendimentos remetidos para pagamento de determinados serviços ${ }^{491}$ e ilustrava o entendimento da União em relação à tributação de tais rendimentos relacionados com a prestação de serviços executados integralmente fora do território brasileiro. O item VII, da referida Portaria, determinava que "se os serviços por ela previstos fossem vendidos por

487 “Art. 292. Estão sujeitos ao desconto do imposto, na fonte:

$\S 1^{\circ}$ à razão de $25 \%$ (vinte e cinco por cento), ressalvado o disposto no parágrafo único, todos os rendimentos tributáveis de acordo com êste Regulamento, quando percebidos pelas pessoas físicas ou jurídicas a que se refere o art. 33, excetuados os de que tratam os incisos $2^{\circ}$ e $3^{\circ}$ (Lei $\mathrm{n}^{\circ} 3.470$, art. 77; Lei $\mathrm{n}^{\circ} 4.131$, artigos. 13, 43 e 46 e Lei $\mathrm{n}^{\circ} 4.390$ (*), de 29 de agosto de 1964, artigo $\left.1^{\circ}\right)$."

488 "Art. 300. Aquêles que pagarem rendimentos a residentes ou domiciliados no estrangeiro deverão prestar às repartições ou aos agentes fiscais do imposto de renda todos os esclarecimentos que lhes forem exigidos (Decreto-lei $n^{\circ} 5.844$, artigo 137 e Lei $n^{\circ} 2.354$, artigo $7^{\circ}$ )."

489 “Art. $9^{\circ}$. Para qualificar e reger as obrigações, aplicar-se-á a lei do país em que se constituírem. (...)

$\S 2^{\circ}$. A obrigação resultante do contrato reputa-se constituída no lugar em que residir o proponente.”

490 Ao votar o Ministro Relator Oswaldo Trigueiro sustentou que "não se cogita da importação de mercadorias ou de serviços mediante pagamento a prazo, em prestações acrescidas de juros convencionais. O que a espécie configura é apenas o pagamento do preço pela compra de um serviço, nas mesmas condições em que se realizaria, por exemplo, a remessa para o pagamento a um hospital, a uma escola, a uma alfaiataria, cujos serviços houvessem sido utilizados por um brasileiro em viagem pelo exterior. Parece-me de toda evidência que não se aplica à hipótese o DL 401-68, que dispõe sobre a remessa de juros nas importações com financiamento do preço. Nestas condições, não há o que censurar na decisão recorrida que, de resto, se inspirou na doutrina da própria Administração Federal, tal como compendiada na Portaria 184, de 8.6.1966. Neste ato está dito que, se os serviços são vendidos por empresa domiciliada no exterior, e produzidos mediante atividade exercida exclusivamente no exterior, o preço pago na importação dos mesmos serviços não constitui rendimento sujeito a tributação do Imposto de Renda."

491 A Portaria do Ministério da Fazenda no 184/66 abordava apenas e tão somente a prestação de serviços envolvendo a elaboração de projetos de investimento, os quais não guardam relação com as licenças de uso de software, objeto do presente estudo. 
empresas domiciliadas no exterior que não possuíssem dependência no Brasil e fossem produzidos pela empresa vendedora mediante atividade exercida exclusivamente no exterior, o preço pago na importação do serviço não constituiria rendimento sujeito à tributação do imposto de renda, quer na incidência sobre o lucro das pessoas jurídicas domiciliadas no país, quer na incidência sobre rendimentos de pessoas residentes ou domiciliadas no exterior (Decreto-Lei n ${ }^{\circ}$ 5.844, de 23 de setembro de 1943, art. 97; Regulamento o Imposto de Renda, art. 292).”

Diante de tal entendimento, o Supremo Tribunal Federal editou a Súmula $n^{\circ} 585^{492}$, segundo a qual "não incide o imposto de renda sobre a remessa de divisas para pagamento de serviços prestados no exterior, por empresa que não opera no Brasil."

Como bem pontua o Professor Gerd Willi Rothmann ${ }^{493}$, o Brasil apenas tributava “as hipóteses em que, concomitantemente, a fonte de produção e a fonte de pagamento dos rendimentos pagos a residente no exterior se situavam no território nacional."

Entretanto, “a partir de 04.09.1975, por força do Decreto-lei no 1.418 (art. $6^{\text {o494}}$ ), o imposto de renda passou a incidir sobre os rendimentos de serviços técnicos e de assistência técnica, administrativa e semelhantes derivados do Brasil e recebidos por pessoas físicas ou jurídicas, residentes ou domiciliadas no exterior, independentemente da forma de pagamento e do local e data em que a operação tenha sido contratada, os serviços executados ou a assistência prestada." 495

Assim, o entendimento jurisprudencial foi alterado e o Supremo Tribunal Federal passou a aplicar o princípio da fonte pagadora em detrimento do princípio da residência por entender que o art. $9^{\circ}$, da Lei de Introdução às Normas do Direito Brasileiro, não mais

\footnotetext{
492 <http://www.stf.jus.br/arquivo/cms/jurisprudenciaSumula/anexo/Sumula_do_STF_1_a_736.pdf.>. Acesso em: 06 dez. 2012.

493 Inconstitucionalidade, op. cit.,p. 110.

494 “Art. $6^{\circ}$. O imposto de $25 \%$ de que trata o artigo 77 da Lei ${ }^{\circ} 3.470$, de 28 de novembro de 1958 , incide sobre os rendimentos de serviços técnicos e de assistência técnica, administrativa e semelhantes derivados do Brasil e recebidos por pessoas físicas ou jurídicas residentes ou domiciliadas no exterior, independentemente da forma de pagamento e do local e data em que a operação tenha sido contratada, os serviços executados ou a assistência prestada."

495 Consoante consta do acórdão proferido por ocasião do julgamento do Recurso Extraordinário $n^{\circ} 101.066$ 5.
} 
representava óbice à pretensão fiscal, consoante se constata da ementa do acórdão proferido nos autos do Recurso Extraordinário n ${ }^{\text {o }} 103.567 .{ }^{496}$

Isso porque, diferentemente do que ocorria com o Decreto-lei $\mathrm{n}^{\circ} 5.844 / 43$ e com o Decreto $n^{\circ} 58.400 / 66$, o Decreto-lei $n^{\circ} 1.418 / 75$ expressamente estabelecia a incidência do imposto de renda retido na fonte sobre os rendimentos de serviços técnicos e de assistência técnica e semelhantes derivados do Brasil e recebidos por pessoas físicas ou jurídicas residentes ou domiciliadas no exterior.

Na sua brilhante tese de livre-docência, o Professor Gerd Willi Rothmann ${ }^{497}$ chama a atenção para o fato de a inovação perpetrada pelo Decreto-lei $n^{\circ} 1.418 / 75$ não ter tido a amplitude que a Administração Tributária pregava, para com base nele tributar todo e qualquer rendimento remetido a residentes e domiciliados no exterior por conta de prestação de serviços. A bem da verdade, o referido DL apenas respaldava a incidência do IRRF sobre rendimentos advindos de prestação de serviços técnicos e de assistência técnica, administrativa e semelhantes.

Não obstante isso, posteriormente, os arts. $554^{498}$ e 555, inciso $I^{499}$, do Regulamento do Imposto de Renda, aprovado pelo Decreto $\mathrm{n}^{\circ} 85.450 / 80$, passaram a regulamentar o art. 97, “a”, do Decreto-lei n 5.844/43 (que já havia sido afastado pelo STF antes da edição do

496 “A partir do Decreto-lei no 1.418/75, é lícita a retenção do imposto de renda na remessa de divisas para o exterior, pagando serviços prestados por empresa ali sediada. Impertinência do artigo $9^{\circ}$ da Lei de Introdução ao Código Civil."

497 Inconstitucionalidade, op. cit.,p. 110.

498 “Art. 554 - Estão sujeitos ao imposto na fonte, de acordo com o disposto neste Título, os rendimentos e os ganhos de capital provenientes de fontes situadas no País, quando percebidos:

I - pelas pessoas físicas ou jurídicas residentes ou domiciliadas no exterior (Decreto-lei $\mathrm{n}^{\circ}$ 5.844/43, art.97, a);

(...)

$\S$ único - Nos casos de falecimento da pessoa física ou domiciliada no exterior, o imposto na fonte será recolhido em nome do espólio até a homologação da partilha ou a adjudicação dos bens."

499 “Art. 555 - Estão sujeitos ao desconto do imposto na fonte:

I - à alíquota de $25 \%$ (vinte e cinco por cento), os rendimentos percebidos pelas pessoas físicas ou jurídicas a que se refere o art. anterior, inclusive os auferidos em operações de curto prazo e os ganhos de capital relativos a investimentos em moeda estrangeira, excetuados os de que tratam os incisos II e III $\left(\right.$ Lei $^{\circ} 3.470 / 58$, art. 77, e Decreto-lei no $1.401 / 75$, art. $4^{\circ}$ );

(...)

$\S 6^{\circ}$ - O imposto de que trata o inciso I deste art. incide sobre os rendimentos de serviços técnicos e de assistência técnica, administrativa e semelhantes derivados do Brasil e recebidos por pessoas físicas ou jurídicas residentes ou domiciliadas no exterior, independentemente da forma de pagamento e do local e data em que a operação tenha sido contratada, os serviços técnicos executados ou a assistência técnica prestada (Decreto-lei n ${ }^{\circ} 1.418 / 75$, art. $6^{\circ}$ )." 
DL $\left.\mathrm{n}^{\circ} 1.418 / 75\right)$, como se a partir daquele momento a incidência do IRRF sobre demais rendimentos remetidos ao exterior estivesse respaldada.

O referido art. 97 determinava a incidência do imposto de renda retido na fonte sobre os rendimentos percebidos pelos residentes ou domiciliados no exterior, bem como o art. 77 da Lei $n^{\mathrm{o}} 3.470 / 58^{500}$ e o art. $4^{\mathrm{o}}$ do Decreto-lei $\mathrm{n}^{\mathrm{o}} 1.401 / 75^{501}$ impunham a observância da respectiva alíquota de $25 \%$.

Já sob a égide do RIR/80, foi editada a Portaria do Ministro de Estado da Fazenda $\mathrm{n}^{\mathrm{o}}$ 181/89, segundo a qual seriam tributados na forma dos arts. 554 e 555, I, do RIR/80, acima mencionados, "os rendimentos correspondentes a direitos autorais pagos a beneficiários residentes ou domiciliados na aquisição de programas de computadores 'software', para distribuição e comercialização no País ou para uso próprio, sob a modalidade de cópia única".

Portanto, já em 1989, por meio de Portaria, a União passou a exigir o imposto de renda retido na fonte, à alíquota de $25 \%$, sobre os pagamentos remetidos ao exterior como contraprestação pela aquisição dos direitos autorais de comercialização, distribuição e de uso de programas de computador.

Da citada Portaria do Ministro de Estado da Fazenda são extraídas duas questões importantes. A primeira diz respeito à instituição de tributo por instrumento legislativo inadequado já que Portaria é norma secundária que nem de longe possui força de lei ${ }^{502}$. A segunda refere-se ao reconhecimento de que a remuneração pela aquisição dos direitos de comercialização, de distribuição e de uso de software, já integrava a seara do direito autoral.

500 “Art. 77. O item $1^{\circ}$ do art. 97, do Regulamento do Impôsto de Renda passa a vigorar com a seguinte redação:

$1^{\circ}$ ) à razão de $25 \%$ (vinte e cinco por cento):

I - os rendimentos percebidos pelas pessoas físicas ou jurídicas, residentes ou domiciliadas no estrangeiro, inclusive aqueles oriundos da exploração de películas cinematográficas;

II - os rendimentos percebidos pelos residentes no país, que estiverem ausentes no exterior por mais de doze meses."

501 "Art. $4^{\circ}$ Os ganhos de capital, auferidos por residentes ou domiciliados no exterior, relativos a investimentos em moeda estrangeira não abrangidos por este Decreto-lei, continuam sujeitos à tributação na fonte, à razão de $25 \%$ (vinte e cinco por cento)."

${ }^{502}$ Naquela época também não vigorava nenhum dispositivo legal que previsse a incidência do imposto e renda sobre as remessas ao exterior, a título de remuneração pela licença de uso de software. 
Em 27.12.1995, sobreveio a Lei n ${ }^{\circ} 9.249$ que, dentre as alterações na legislação do imposto de renda, reduziu de $25 \%$ para $15 \%$ a alíquota do imposto incidente sobre os rendimentos recebidos por residentes ou domiciliados no exterior. ${ }^{503}$

Todavia, somente em 20.01.1999, com a publicação da Lei $n^{\circ} 9.779 / 99$ (art. $7^{\text {o504}}$ ) a incidência do IRRF (à alíquota de $25 \%$ ) sobre os pagamentos enviados ao exterior como contraprestação de prestação de serviços passou a estar prevista em lei.

Portanto, o Decreto-lei $\mathrm{n}^{\circ} 1.418 / 75$ diz respeito à tributação na fonte da contraprestação de determinados serviços (serviços técnicos, de assistência técnica, administrativa e semelhantes), enquanto a Lei $\mathrm{n}^{\circ}$ 9.779/99 grava com o IRRF todas as contraprestações por quaisquer serviços.

O art. 685, do atual RIR/99 ${ }^{505}$ (aprovado pelo Decreto $\mathrm{n}^{\mathrm{o}} 3.000 / 99$ ), regulamenta o art. 100, do Decreto-lei $n^{\circ} 5.844 / 43$, o art. 77, da Lei $n^{\circ} 3.470 / 58$, o art. 28, da Lei $n^{\circ}$ 9.249/95 e os arts. $7^{\circ}$ e $8^{\circ}$, da Lei $n^{\circ}$ 9.779/99, impondo a incidência do IRRF, à alíquota de $15 \%$ sobre os rendimentos em geral, remetidos às pessoas físicas ou jurídicas residentes ou domiciliadas no exterior, salvo se houver legislação específica que preveja alíquota diversa.

503 “Art. 28. A alíquota do imposto de renda de que tratam o art. 77 da Lei n 3.470 , de 28 de novembro de 1958 e o art. 100 do Decreto-Lei $n^{\circ} 5.844$, de 23 de setembro de 1943, com as modificações posteriormente introduzidas, passa, a partir de $1^{\circ}$ de janeiro de 1996 , a ser de quinze por cento."

504 “Art. $7^{0}$ Os rendimentos do trabalho, com ou sem vínculo empregatício, e os da prestação de serviços, pagos, creditados, entregues, empregados ou remetidos a residentes ou domiciliados no exterior, sujeitamse à incidência do imposto de renda na fonte à alíquota de vinte e cinco por cento."

505 “Art. 685. Os rendimentos, ganhos de capital e demais proventos pagos, creditados, entregues, empregados ou remetidos, por fonte situada no País, a pessoa física ou jurídica residente no exterior, estão sujeitos à incidência na fonte (Decreto-Lei no 5.844, de 1943, art. 100, Lei no 3.470, de 1958, art. 77, Lei no 9.249, de 1995, art. 23, e Lei no 9.779, de 1999, arts. 7o e 8o):

I - à alíquota de quinze por cento, quando não tiverem tributação específica neste Capítulo, inclusive:

(...)

II - à alíquota de vinte e cinco por cento:

a) os rendimentos do trabalho, com ou sem vínculo empregatício, e os da prestação de serviços;

b) ressalvadas as hipóteses a que se referem os incisos V, VIII, IX, X e XI do art. 691, os rendimentos decorrentes de qualquer operação, em que o beneficiário seja residente ou domiciliado em país que não tribute a renda ou que a tribute à alíquota máxima inferior a vinte por cento, a que se refere o art. 245 .

$\S 1$ - Prevalecerá a alíquota incidente sobre rendimentos e ganhos de capital auferidos pelos residentes ou domiciliados no País, quando superior a quinze por cento (Decreto-Lei no 2.308 , de 1986, art. 2º e Lei no9.249, de 1995, art. 18).

$\S 2^{\text {o }}$ No caso do inciso II, a retenção na fonte sobre o ganho de capital deve ser efetuada no momento da alienação do bem ou direito, sendo responsável o adquirente ou o procurador, se este não der conhecimento, ao adquirente, de que o alienante é residente ou domiciliado no exterior.

§ 3- O ganho de capital auferido por residente ou domiciliado no exterior será apurado e tributado de acordo com as regras aplicáveis aos residentes no País (Lei n- 9.249, de 1995, art. 18).” 
A título exemplificativo, em caso de rendimentos qualificados como pagamentos por prestação de serviços, aplica-se a alíquota de 25\% (art. 685, II, “a”, do RIR/99). Em caso de prestação de serviços técnicos e de assistência técnica, administrativa e semelhantes, os respectivos rendimentos derivados do Brasil e recebidos por residentes ou domiciliados no exterior, estão sujeitos ao IRRF à alíquota de 25\% (art. 708, RIR/99 $9^{506}$ e do art. $6^{\circ}$ do Decreto-lei $\left.n^{\circ} 1.418 / 75\right)$.

Neste aspecto, vale rememorar que a Lei $\mathrm{n}^{\circ}$ 10.168/00 (com redação dada pela Lei $\mathrm{n}^{\mathrm{o}} 10.332 / 01$ ), reduziu a alíquota do IRRF para $15 \%$ sobre as importâncias remetidas ao exterior a título de remuneração de serviços de assistência administrativa e semelhantes.

Os royalties a qualquer título remetidos ao exterior estão sujeitos ao imposto de renda retido na fonte, à alíquota de $15 \%$, consoante prevê o art. 710, do Regulamento do Imposto de Renda/99 ${ }^{507}$ (e o art. $3^{\text {o }}$, da Medida Provisória $\left.n^{\text {o }} 1.749-37 / 99\right) .{ }^{508}$

Note-se que a legislação do imposto de renda é bastante confusa e requer atenção redobrada, notadamente quando se tratar de rendimentos enviados ao exterior para remunerar a concessão de licença de uso de programas de computador.

Para a Autoridade Fiscal Administrativa, o IRRF não incide sobre a remuneração enviada ao exterior a título de pagamento por licença de uso de software "de prateleira" por entender que se trata de uma compra de mercadoria para revenda. ${ }^{509}$

506 “Art. 708. Estão sujeitos à incidência do imposto na fonte, à alíquota de vinte e cinco por cento, os rendimentos de serviços técnicos e de assistência técnica, administrativa e semelhantes derivados do Brasil e recebidos por pessoa física ou jurídica residente ou domiciliada no exterior, independentemente da forma de pagamento e do local e data em que a operação tenha sido contratada, os serviços executados ou a assistência prestada (Decreto-Lei no 1.418, de 3 de setembro de 1975, art. 6-o , Lei no 9.249, de 1995, art. 28 e Lei $\mathrm{n}^{\mathrm{o}} 9.779$, de 1999 , art. $7^{\mathbf{0}}$ ).

Parágrafo único. A retenção do imposto é obrigatória na data do pagamento, crédito, entrega, emprego ou remessa dos rendimentos (Decreto-Lei no 5.844, de 1943, art. 100).”

507 “Art. 710. Estão sujeitas à incidência na fonte, à alíquota de quinze por cento, as importâncias pagas, creditadas, entregues, empregadas ou remetidas para o exterior a título de royalties, a qualquer título (Medida Provisória no 1.749-37, de 1999, art. 3o)."

${ }^{508}$ Em 27.08.2001, quando já vigorava a Lei $\mathrm{n}^{\circ}$ 10.168/00 (instituidora da CIDE), a Medida Provisória $\mathrm{n}^{\circ}$ 1.459/96, reeditada sob o $\mathrm{n}^{\circ} 2.159-70$, reduziu para $15 \%$ a alíquota do imposto de renda retido na fonte incidente sobre as remessas ao exterior para pagamento de serviços técnicos, de assistência técnica e de royalties de qualquer natureza a partir da cobrança da contribuição instituída pela Lei $\mathrm{n}^{\circ}$ 10.168/00 ("Art. 3- Fica reduzida para quinze por cento a alíquota do imposto de renda incidente na fonte sobre as importâncias pagas, creditadas, entregues, empregadas ou remetidas ao exterior a título de remuneração de serviços técnicos e de assistência técnica, e a título de royalties, de qualquer natureza, a partir do início da cobrança da contribuição instituída pela Lei n ${ }^{\circ} 10.168$, de 29 de dezembro de 2000").

509 “Solução de Consulta n ${ }^{\circ}$ 63/10, da Superintendência Regional da Receita Federal da $10^{\text {a }}$ Região Fiscal 
Não obstante isso, por razões de convencimento e coerência, não podemos deixar de reiterar a nossa posição quanto ao fato de a obtenção de licença de uso de software "de prateleira" não consistir em uma "compra e venda" de mercadoria, dado que o objeto da transação é um bem imaterial (obra intelectual) passível de ser objeto de cessão de direitos (autorais) e cujo suporte material atua como mero acessório para que o referido bem seja oferecido ao público em geral.

Já em relação ao software desenvolvido "sob encomenda" (em cópia única), a Autoridade Fiscal Administrativa não vislumbra a existência de duas transações distintas, quais sejam: (i) a contratação de uma prestação de serviço; e, (ii) a obtenção de licença de uso (quando for o caso). Em sendo assim, a Secretaria da Receita Federal posiciona-se favoravelmente à incidência do IRRF sobre os rendimentos decorrentes de ambas as transações, sem distingui-las ou sem segregar os rendimentos, adotando-os como royalties (rendimentos de direitos autorais):

\begin{abstract}
"Solução de Consulta n ${ }^{\circ}$ 75/11, da Superintendência Regional da Receita Federal da $5^{\mathrm{a}}$ Região Fiscal

Assunto: Imposto sobre a Renda Retido na Fonte - IRRF. Ementa: INCIDÊNCIA. REMESSA AO EXTERIOR. LICENÇA DE USO DE SOFTWARE. Ocorre a incidência do imposto de renda na fonte sobre as importâncias pagas, creditadas, entregues, empregadas ou remetidas ao exterior, a título de aquisição de programas de computador (softwares), cujo conteúdo tenha sido materialmente preparado para atender a uma necessidade específica de trabalho de usuário (seguros) e cuja disponibilização ocorra em cópias limitadas, não dirigidas ao público em geral, deixando assim de configurar a modalidade standard, dita "de prateleira", e revestindo-se, a operação, da condição de rendimentos de direitos autorais ("royalties"). DISPOSITIVOS LEGAIS: Dispositivos Legais: Decreto ${ }^{\circ} 3.000$, de 1999, art. 682, 685 e 710 e Portaria MF no 181, de 28/09/1989."
\end{abstract}

\footnotetext{
ASSUNTO: Imposto sobre a Renda Retido na Fonte - IRRF. EMENTA: Não estão sujeitos à incidência de Imposto de Renda na Fonte os valores remetidos ao exterior pela aquisição de "software de prateleira" (cópias múltiplas) para revenda por pessoa jurídica detentora de licença de comercialização outorgada por fabricante estrangeiro. É irrelevante a forma de movimentação do programa do fabricante ao distribuidor ou revendedor, se por remessa de suporte físico, via internet (download) ou por reprodução a partir de matriz. Caracterizando-se, no entanto, licenciamento temporário do uso de software, os valores remetidos ao exterior em pagamento constituem remuneração de cessão de direito, sendo tributados pelo IRRF à alíquota de $15 \%$, conforme art. 72 da Lei n ${ }^{\circ}$ 9.430, de 1996."

"Solução de Consulta n $40 / 02$, da Superintendência Regional da Receita Federal da 5a Região Fiscal ASSUNTO: Imposto sobre a Renda Retido na Fonte - IRRF

EMENTA: INCIDÊNCIA. REMESSA AO EXTERIOR. AQUISIÇÃO DE SOFTWARE PARA REVENDA. Não incide o imposto de renda na fonte sobre as importâncias pagas, creditadas, entregues, empregadas ou remetidas ao exterior, a título de aquisição de programa de computador (software), quando a operação se equiparar à compra de mercadoria (software de prateleira) para revenda. Tratandose de remuneração de contratos de cessão ou licença de direitos de uso, fruição ou disposição, as importâncias pagas, creditadas, entregues, empregadas ou remetidas ao exterior ficam sujeitas à incidência do imposto de renda na fonte, por caracterizar pagamento de direitos autorais (royalties)."
} 
Equivoca-se a SRF ao não considerar que o uso do software "de prateleira", assim como o do software "sob encomenda", dá-se por meio de licença que é a concessão parcial de direitos autorais sobre a obra intelectual (obrigação de dar), de modo que os rendimentos enviados ao exterior em casos assim podem possuir dupla natureza: remuneração de direitos autorais e/ou remuneração por trabalho/serviço prestado.

No caso do programa desenvolvido "sob encomenda", há uma típica prestação de serviços, pois o programa é desenvolvido de forma personalizada com o intuito de satisfazer as necessidades do contratante.

Todavia, consoante restou demonstrado quando da exposição da controvérsia envolvendo a CIDE, a remuneração pelo uso, fruição, exploração de direitos autorais quando pagos diretamente ao autor da obra está excluída do conceito de royalty, nos termos do art. 22, da Lei $n^{\circ} 4.506 / 64$.

Tendo em vista que o atual Regulamento do Imposto de Renda não dispõe sobre a retenção na fonte do imposto sobre os rendimentos enviados ao exterior para remunerar a concessão de licença de uso de software, tão pouco qualquer norma tributária assim o faz, a exigência do imposto é desprovida de embasamento legal.

Ademais, a incidência do imposto de renda sobre a remuneração enviada ao exterior para pagar a prestação de serviços de elaboração de software "sob encomenda" também se mostra desarrazoada, pois configura invasão de competência tributária por incidir sobre mesma base de cálculo do ISS (= preço do serviço), de competência municipal. $^{510}$

Por conta disso, é salutar a ponderação do Professor Gerd Willi Rothmann ${ }^{511}$ sobre a identidade de fatos geradores do IRRF e do ISS, em total ofensa ao art. 154, da Constituição, já que a União somente pode se valer da sua competência residual para, por meio de lei complementar, instituir imposto ainda não previsto e que não tenha fato gerador ou base de cálculo próprios dos discriminados na Constituição (além de não poder ser cumulativo).

${ }_{510}$ Cf. ROTHMANN, Gerd Willi, Inconstitucionalidade, op. cit.,p. 112/113.

511 Inconstitucionalidade, op. cit., p. 112/113. 
A bem da verdade, a incidência do IRRF sobre os rendimentos enviados ao não residente, prestador de serviços, é matéria de elevada indagação jurídica por não constituir acréscimo patrimonial propriamente dito. A remuneração enviada ao exterior constitui rendimento bruto do não residente.

Nos termos do art. 43, do CTN, o imposto incide sobre a aquisição da disponibilidade econômica ou jurídica de renda e de proventos de qualquer natureza. Por mais problemática que seja a atribuição de um conceito de renda, é pacífico na doutrina ${ }^{512}$ e na jurisprudência ${ }^{513}$ que o IR incide sobre o acréscimo patrimonial ocorrido em um espaço de tempo.

Entretanto, nos termos da legislação interna, o acréscimo patrimonial só é obtido mediante a contraposição de todas as receitas e rendimentos ("receitas") e de todos os custos e despesas (“despesas”), auferidos em um determinado período. Assim, a renda tributável (“o lucro") é o resultado algébrico positivo dessa contraposição de receitas e despesas.

O conceito de lucro engloba todas as receitas e despesas do contribuinte. Isto é, quaisquer rendimentos recebidos, efetivamente relacionados com sua atividade empresarial, a priori, são considerados elementos integrantes do lucro, enquadrando-se, aí, os derivados da prestação de serviços, mas estes, por si sós, não representam, acréscimo patrimonial.

Nos termos do art. 45, do CTN, o contribuinte do IRRF é aquele que aufere e é titular da disponibilidade econômica ou jurídica da renda ou dos proventos de qualquer natureza. A fonte pagadora é responsável tributária pela retenção.”.514

Em sendo o contribuinte um não residente, a efetiva apuração da renda tributável somente ocorrerá ao final de determinado período e mediante a contraposição das "receitas" e das "despesas" de acordo com normas vigentes no país de residência.

\footnotetext{
512 Cf. OLIVEIRA, Ricardo Mariz, Fundamentos do Imposto de Renda, São Paulo: Quartier Latin, 2008, p. $41 / 42$.

513 Vide RE n ${ }^{\circ} 117.887-6 / S P$, RE no $201.465-6 / M G$, RESP n ${ }^{\circ}$ 571.886-RS, RESP no 770.078/SP, RESP n 320.455/RJ e RESP n ${ }^{\circ} 181.912 / P R$.

514 Cf. MACHADO, Hugo de Brito, Curso de Direito Tributário, São Paulo: Malheiros, 2008, p. 142.
} 
Portanto, é impossível para o remetente avaliar tratar-se ou não de efetivo acréscimo patrimonial da empresa estrangeira, de modo que a retenção do imposto de renda na fonte incide sobre materialidade que não constitui a renda tributável propriamente dita, pois o rendimento bruto (contraprestação pela prestação de serviço) apesar de ser elemento integrante da renda, pode não ser ensejar efetivo acréscimo patrimonial.

Agregue-se a isso o fato de a tributação do rendimento bruto na fonte impedir a aplicação do princípio da capacidade contributiva (art. $145, \S 1^{\circ}$, da $\mathrm{CF}$ ), pois ao procederse desta maneira não se prestigia a incidência do imposto sobre signos presuntivos de riqueza, de forma graduada e de acordo com a capacidade econômica do contribuinte, tornando o IR, que deveria ser pessoal, em imposto real. ${ }^{515}$

${ }^{515}$ Cf. ROTHMANN, Gerd Willi, Inconstitucionalidade, op. cit., p. 99/114. 


\section{CONCLUSÕES}

1. - O software é uma série de dígitos binários que funciona como um conjunto de impulsos elétricos dispostos numa sequência preordenada que se sucedem no computador para que ele execute tarefas definidas pelo programador;

2. - No código-fonte estão a estrutura do programa e os comandos para o hardware alcançar o resultado lógico pretendido. Trata-se de material importantíssimo que permite compreender a sua estrutura, os seus comandos e a sua tecnologia;

3. - A regulamentação mais importante para a proteção de obras intelectuais em âmbito internacional foi realizada pela OMPI com a celebração do Tratado sobre Direito de Autor, que estabelece que o software é protegido como obra literária, nos termos da Convenção de Berna. No mesmo sentido, o TRIPS prescreve que o programa de computador, seja o código-fonte ou o código-objeto, deve ser protegido como obra literária, observando-se o disposto na mencionada Convenção;

4. - O Brasil aderiu ao regramento internacional que é conferido aos programas de computador, o que explica a edição da Lei n ${ }^{o}$ 9.609/98 (sucessora da Lei $n^{\circ}$ 7.646/87) segundo a qual o regime de proteção à propriedade intelectual do software é o conferido às obras literárias pela legislação de direitos autorais e conexos vigentes;

5. - De acordo com a Lei $\mathrm{n}^{\circ}$ 9.609/98, software é a expressão de um conjunto organizado de instruções em linguagem natural ou codificada, contida em suporte físico de qualquer natureza, de emprego necessário em máquinas automáticas de tratamento de informação, dispositivos, instrumentos ou equipamentos periféricos, baseados em técnica digital ou análoga, para fazê-los funcionar de modo e para fins determinados;

6. - O art. $9^{\circ}$, da Lei $n^{\circ} 9.609 / 98$, prevê que o uso do programa se dá por meio de contrato de licença de uso, que consiste na outorga de uma autorização para o uso por parte do titular dos direitos autorais sobre o programa em favor do usuário interessado. A licença de uso determina as condições de utilização, o prazo e as limitações; 
7. - A licença de uso do programa se aperfeiçoa mediante a manifestação de anuência, tácita ou expressa, do usuário em relação às condições e termos previstos no contrato de licença de uso (tanto do programa entregue por download, quanto do que é entregue fisicamente em suporte individual);

8. - Os bens materiais são passíveis de alienação por meio de "compra e venda", mediante tradição, enquanto os imateriais são alienados ou cedidos por meio de cessão de direitos;

9. - Diferentemente da cessão, a licença de uso não pressupõe a transferência dos direitos patrimoniais do autor (transferência jurídica do bem). A primeira até poderia ser equiparada a uma operação mercantil (“compra e venda"), mas a segunda não se equipara. Diz-se "até poderia" se não fosse o fato de o programa de computador não poder ser considerado uma mercadoria, por se tratar de um bem imaterial;

10. - A licença de uso mais se aproxima da locação de bem móvel, uma obrigação de dar, de modo que o usuário não se sub-roga nos direitos patrimoniais como se proprietário fosse. Poderá, no máximo, tornar-se proprietário do suporte físico que o contempla;

11. - A lei do software não respalda a segregação do software em classes. Existem variações quanto às diversas espécies de licenças de uso que podem ser concedidas ou variedades quanto ao meio pelo qual os programas são disponibilizados;

12. - Ao julgar o RE $n^{\circ}$ 176.626-3, sobre a incidência ou não do ICMS sobre as operações com software padrão disponibilizado em lojas de departamentos, o STF acolheu a seguinte classificação tripartite de programas: (i) software padrão (“de prateleira”); (ii) software desenvolvido sob encomenda; e, (iii) software adaptado ao cliente (híbrido);

13. - Os programas "padrão" são produtos acabados, produzidos em massa, em grandes quantidades, são destinados a um vasto público e comercializados em grandes lojas de departamentos e também são denominados de software "de prateleira"; os programas desenvolvidos sob encomenda são elaborados a partir das exigências do seu encomendante de modo a satisfazer as suas necessidades; os programas adaptados ao cliente constituem uma forma híbrida entre os programas padrão e os que são produzidos sob encomenda; 
14. - O fato gerador do ICMS independe de qualquer atividade estatal específica, relativa ao contribuinte; a sua finalidade é tipicamente fiscal; é não-cumulativo (compensando-se o que for devido em cada operação relativa à circulação de mercadorias ou prestação de serviços com o montante cobrado nas anteriores); o contribuinte é qualquer pessoa, física ou jurídica, que realize com habitualidade operações de circulação de mercadoria ou prestações de serviços de transporte interestadual e intermunicipal e de comunicação, ainda que as operações e as prestações se iniciem no exterior; o imposto pode ser seletivo em razão da essencialidade das mercadorias e dos serviços;

15. - A regra-matriz do ICMS-mercantil pode ser assim resumida: Hipótese: a) critério material - realizar operações relativas à circulação de mercadorias; b) critério espacial qualquer lugar do território do Estado ou do Distrito Federal que tenha editado a lei instituidora do imposto; c) critério temporal - via de regra, no momento da saída das mercadorias do estabelecimento comercial, industrial ou produtor; Consequente: d) critério pessoal - sujeito ativo é o Estado ou o Distrito Federal e sujeito passivo é a pessoa física ou jurídica que dá ensejo às operações de circulação de mercadorias; e) critério quantitativo - base de cálculo é o valor da operação e a alíquota é um percentual definido em lei;

16. - A partir da repartição de competências tributárias a CF diferenciou produto de bem, este de mercadoria, esta de serviço, este da propriedade intelectual ou da propriedade industrial e assim sucessivamente, justamente para impedir que os entes federados invadam a competência alheia;

17. - A construção de conceitos constitucionais deve levar em conta a repartição de competências tributárias, os conceitos de direito privado e os conceitos pré-constitucionais que por ventura tenham sido acolhidos como conceitos constitucionais pressupostos;

18. - O ICMS incide sobre "operações" assim entendidas como atos juridicamente relevantes, bilaterais, regulados pelo direito mercantil, que se repetem sucessivamente e que impulsionam a circulação de mercadorias do fabricante até o consumidor final;

19. - Nos termos do art. 155, II, da CF, "circulação" e "mercadorias" qualificam as “operações" tributadas. A "circulação" pressupõe sucessivas transações mercantis (fatos 
jurídicos) acompanhadas de transferências jurídicas (transferência da titularidade) das mercadorias. Mercadoria é bem corpóreo da atividade empresarial do produtor, industrial e comerciante, posta em circulação até ser adquirido pelo consumidor;

20. - A alteração na CF que incluiu a energia elétrica como materialidade tributável pelo ICMS denota que, via de regra, mercadoria é bem corpóreo acompanhado do aspecto subjetivo quanto à sua destinação mercantil;

21. - O software é um bem móvel, de natureza intelectual, equiparado à obra literária, protegido pelo direito autoral e incorpóreo passível de ser transferido a outrem por cessão de direitos e não por operações mercantis de compra e venda tributadas pelo ICMS;

22. - O suporte físico é acessório que viabiliza o acesso à obra intelectual; materializa o programa de computador, não possui o condão de afastá-lo da tutela do direito autoral e é apenas um dos meios pelos quais o bem imaterial é posto à disposição dos interessados. Já é possível distribuir e/ou entregar o software por download, por exemplo;

23. - É impróprio utilizar a expressão "compra e venda" para as questões envolvendo a obtenção de licença de uso de programas de computador. A "compra e venda" guarda relação com a cessão onerosa e integral dos direitos autorais patrimoniais sobre o software, pois esta sim pressupõe que o autor "aliene" a titularidade dos referidos direitos, enquanto a licença de uso nada mais é do que a concessão de autorização para utilização do programa sob determinadas condições;

24. - A CF e a LC no 87/96 não trazem nenhuma disposição que faça da obtenção da licença de uso de software, das transações eletrônicas de dados (download) ou das cessões de direitos imateriais fatos subsumíveis à incidência do ICMS, de modo que a ampliação da incidência do imposto deverá ser feita mediante emenda constitucional;

25. - Ao julgar o RE no 176.626-3, o STF decidiu que não incide ICMS sobre operações de licenciamento ou de cessão de direito de uso de programas de computador. Considerando que todas as transações que têm como objeto o uso dos programas de computador estão atreladas a um contrato de licença, sejam eles software "de prateleira", 
"sob encomenda" ou "híbrido", outra conclusão não se admite senão a de que o ICMS não incide sobre a licença de uso, independentemente da classificação que se pretenda dar-lhes;

26. - Mesmo nos casos do software disponibilizado em pacote lacrado, posto à disposição em lojas de departamentos, a figura da "compra e venda" do programa não se perfaz, já que a titularidade do bem imaterial não passa para o domínio do adquirente, que recebe apenas uma autorização para o uso. O ICMS deveria incidir apenas sobre o suporte físico que materializa o bem intelectual;

27. - O ISS é tipicamente fiscal e desvinculado de qualquer atuação estatal; o imposto é devido ao Município onde estiver localizado o estabelecimento prestador; a base de cálculo é o preço do serviço e a alíquota pode variar entre $2 \%$ e $5 \%$; o contribuinte é o prestador do serviço, podendo a lei atribuir a terceiro o dever de retê-lo e recolhê-lo;

28. - A regra-matriz de incidência do ISS pode ser assim resumida: Hipótese: a) critério material - prestar serviços de qualquer natureza, excetuando-se os serviços de transporte interestadual e intermunicipal e de comunicação; b) critério espacial - qualquer lugar do território do Município ou do Distrito Federal (que tenha editado a lei instituidora do imposto) onde esteja localizado o estabelecimento prestador ou onde o serviço tenha sido executado (casos expressamente previstos na lei); c) critério temporal - data em que se considerem prestados os serviços; Consequente: d) critério pessoal - sujeito ativo é o Município ou o Distrito Federal e sujeito passivo é a pessoa física ou jurídica que presta os serviços; e) critério quantitativo - base de cálculo é o preço da prestação de serviços e a alíquota é um percentual (que pode variar de $2 \%$ a $5 \%$ ) definido em lei;

29. - A regra-matriz de incidência tributária do ISS-importação, nos termos da LC n ${ }^{\circ}$ 116/03, pode ser assim resumida: Hipótese: a) critério material - "tomar" serviços provenientes do exterior ou cuja prestação tenha iniciado no exterior; b) critério espacial - qualquer lugar do território do Município ou do Distrito Federal onde esteja localizado o tomador dos serviços; c) critério temporal - data em que se considerem prestados os serviços; Consequente: d) critério pessoal - sujeito ativo é o Município ou o Distrito Federal e sujeito passivo é a pessoa física ou jurídica tomadora dos serviços; e) critério quantitativo - base de cálculo é o preço da prestação de serviços e a alíquota é um percentual (que pode variar de $2 \%$ a $5 \%$ ) definido em lei; 
30. - Além da liberdade para se organizar e para legislar, os Municípios detém autonomia financeira ante a parcela de competência tributária que lhes foi conferida pela Magna Carta. Contudo, o princípio da autonomia municipal não é ilimitado;

31. - O princípio da territorialidade da lei tributária guarda relação direta com as noções de território e base física sobre a qual o ente político exerce soberania fiscal. Todavia, nem todos os fatos ocorridos no seu território podem ser alcançados por suas leis, ante a estrita repartição de competências tributárias constitucionalmente previstas;

32. - O Poder Judiciário prestigia o princípio da territorialidade em matéria de ISS. Em diversos casos já restou decidido que a lei municipal não pode ser dotada de extraterritorialidade, de modo a irradiar efeitos sobre fato ocorrido no território alheio;

33. - Em sendo o ISS um imposto sobre o consumo, seria coerente que a relação obrigacional se estabelecesse entre o prestador do serviço e o Município do local da execução do serviço, tido como "consumido";

34. - A LC n ${ }^{\circ}$ 116/03 reveste-se do caráter de lei nacional, que vincula todos os entes da federação. A lista anexa à lei elenca os serviços tributáveis e deve ser interpretada taxativamente, muito embora seja admissível a interpretação extensiva quanto aos serviços mencionados nos subitens;

35. - Ao determinar a base de cálculo, o fato gerador e o contribuinte do ISS, por exemplo, a LC $n^{\circ} 116 / 03$ exerce a aptidão que lhe foi dada pelo art. 146, da CF, prevenindo conflitos de competência, notadamente quanto à lista dos serviços tributáveis (hipótese de incidência - critério material), quanto à definição do contribuinte (critério pessoal) e quanto ao local onde o serviço é considerado prestado (critério espacial), além de impor limitações ao poder de tributar pela não incidência do imposto sobre a exportação de serviços $\left(\operatorname{art.} 2^{\circ}\right)$;

36. - O conceito constitucional de serviços de qualquer natureza está implícito. A sua extração se dá a partir dos conceitos e definições do direito privado, existentes ao tempo da promulgação da $\mathrm{CF}$, bem como a partir dos princípios constitucionais, da repartição de competências tributárias e das limitações constitucionais ao poder de tributar; 
37. - Prestar serviço é uma obrigação de fazer (nos termos do RE nº 116.121-3-SP), uma prestação de esforço humano em favor de terceiros, com conteúdo econômico, sob regime de direito privado, tendente à obtenção de um bem material ou imaterial;

38. - São comuns os negócios jurídicos que importam transferência da titularidade da mercadoria e a concomitante prestação de esforço humano. Ocorre que, a obrigação de dar consiste em vínculo jurídico que impõe ao devedor a entrega de alguma coisa já existente, enquanto a obrigação de fazer impõe a elaboração de algo até então inexistente;

39. - Somente são tributáveis os serviços prestados como atividade finalística do prestador. Os serviços-meio, assim entendidos como as atividades intermediárias necessárias à consecução do serviço-fim, não podem ser desmembrados e serem tidos como atividades autônomas e individualmente tributados;

40. - Preocupado em não deixar a atividade de financiamento supostamente incólume a qualquer tributo, o que foge dos critérios jurídicos de avaliação, bem como visando a dar interpretação ampla à expressão de qualquer natureza, o STF reavivou a teoria ultrapassada do caráter econômico de serviço, ao julgar o RE no 592.905/SC sobre a incidência do ISS sobre leasing financeiro;

41. - A corrente doutrinária que defende um conceito econômico de serviço acredita que só existem duas espécies de bens suscetíveis de utilidade econômica, quais sejam: os corpóreos, assim tidos como as mercadorias/produtos (que integram hipóteses de incidência de outros tributos diversos do ISS), e os incorpóreos que, por exclusão, constituem serviços indiscriminadamente e são tributados pelos Municípios;

42. - A despeito de a $\operatorname{LC} n^{\circ} 116 / 03$ ser taxativa, nem todas as atividades que dela constam são serviços. Se assim não fosse, a incidência do ISS sobre a locação de bens móveis (item 3.01) não teria sido declarada inconstitucional pelo STF. O item 1.05 da lista (o licenciamento ou cessão de direito de uso de programas de computação) não constitui uma obrigação de fazer, mas sim uma obrigação de dar;

43. - A adequada tributação da (con)cessão de direitos deve ser concretizada pela União mediante o exercício da sua competência residual, nos termos do art. 154, I, da CF, já que a 
cessão de direito sobre bem imaterial não constitui hipótese de incidência de nenhum tributo constitucionalmente previsto;

44. - A elaboração de um programa sob encomenda pressupõe o esforço humano de determinado profissional desempenhado na concretização dos ideais do contratante, motivo pelo qual trata-se de uma prestação de serviço (obrigação de fazer) prevista no item 1.04 (elaboração de programas de computadores) da lista anexa à LC 116/03;

45. - Entretanto, não se pode confundir a elaboração de programas de computadores com o licenciamento ou a cessão de direito de uso de programas de computação (obrigação de dar), que não guarda identidade com o critério material (prestar) serviços de qualquer natureza;

46. - Nos termos do art. $4^{\circ}$, da Lei ${ }^{\circ}$ 9.609/98, se não houver disposição em contrário no contrato, os programas de computador elaborados sob encomenda (prestação de serviço) passam a pertencer ao contratante, o que afasta a licença de uso;

47. - O software híbrido não guarda relação com a prestação de serviço, mas tão somente com à concessão de licença para o seu uso, pois o programa pelo qual o contratante se interessa já existe e é utilizado por outros interessados;

48. - Diferentemente do que ocorre com o ICMS, a CF não autoriza a incidência do ISS sobre a importação dos serviços provenientes do exterior ou cuja prestação se tenha iniciado no exterior do país, de modo que a sua exigência se mostra inconstitucional;

49. - Partindo do dispositivo que desonera a exportação de serviço (art. $2^{\circ}, \mathrm{I}, \S$ único, da LC $n^{\circ} 116 / 03$ ) há quem diga que os serviços desenvolvidos no exterior e cujo resultado ali se verifique (cumulativamente), ainda que o pagamento seja feito por um residente no Brasil, não configura a importação de serviços e que esta somente se perfaz se o serviço for desenvolvido em território nacional ou se o seu resultado aqui se verifique;

50. - O ISS não incide sobre o resultado obtido com a prestação do serviço, mas sobre o esforço pessoal do prestador exercido com o objetivo de satisfazer os interesses do contratante. Entender o contrário é dizer que as obrigações de dar também podem ser 
alcançadas pelo imposto municipal. Se assim fosse, toda obrigação de fazer seria sobreposta por uma obrigação de dar, que ao final prevaleceria tornando letra morta a distinção entre as duas;

51. - O argumento de que o Brasil teria adotado o princípio do destino (que não está expressamente previsto) não respalda a incidência do ISS sobre a importação de serviços, pois a CF depositou ênfase na materialidade (prestar) serviço de qualquer natureza (e não no seu gozo, fruição ou no resultado dela decorrente);

52. - O legislador elegeu o tomador do serviço como responsável tributário (verdadeiro contribuinte). A análise cautelosa da lei denuncia que ocorreu a indevida ampliação da hipótese de incidência do imposto, passando a albergar não apenas a "prestação de serviços", mas também o ato de "tomar serviços";

53. - Ainda que se admita válida a disposição da LC no 116/03, apenas os serviços prestados integral ou parcialmente em território nacional por um não residente podem ser tributados, sob pena de ofensa à definição constitucional pressuposta da (prestação) de serviços de qualquer natureza, consistente em uma obrigação de fazer;

54. - A COFINS-importação tem como fundamento de validade o art. 195, IV, da CF, sendo, portanto, contribuição social securitária, cuja receita destina-se a custear a seguridade social (direitos à saúde, à previdência e à assistência social, nos termos do art. 194). O PIS-importação, por sua vez, é uma contribuição social geral por ter como fundamento de validade o art. $149, \S 2^{\circ}$, II, da CF;

55. - O fato gerador das contribuições é a entrada de bens estrangeiros no território nacional ou a entrega/remessa de valores a residentes ou domiciliados no exterior em razão da importação de serviços;

56. - O software "de prateleira" oriundo do exterior não gera muitos questionamentos na medida em que na importação de bens/produtos a base de cálculo do PIS/COFINS é a mesma utilizada para o imposto de importação, ou seja, o valor aduaneiro que, nos termos da Portaria MF no 181/89 e a IN SRF no 327/03, corresponde ao valor do suporte físico 
(acrescido, todavia, do ICMS incidente no desembaraço aduaneiro e do valor das próprias contribuições);

57. - A ampliação do conceito de valor aduaneiro afronta o conceito definido em acordos internacionais subscritos pelo Brasil e internalizados na ordem jurídica como, por exemplo, no Acordo de Valoração Aduaneira para a implementação do art. VII do GATT;

58. - A incidência do PIS/COFINS-importação sobre a remuneração enviada ao exterior como contraprestação pela licença de uso de programa de computador é flagrantemente ilegal e inconstitucional, pois o fato gerador marcado pela entrada de bens estrangeiros no território nacional (e até a inclusão do ICMS correspondente na base de cálculo das contribuições) pressupõe a existência de desembaraço aduaneiro, mas os bens intangíveis não são desembaraçados;

59. - Sob a ótica da importação de serviços, a Lei $\mathrm{n}^{\circ}$ 10.865/04 expressamente estabelece que as referidas contribuições incidem sobre os serviços prestados por um não residente no Brasil ou no exterior, mas neste último caso o seu resultado deve ocorrer aqui;

60. - A doutrina e a jurisprudência ainda estão divididas sobre a adequada interpretação a ser dada ao vocábulo "resultado", que pode ser interpretado como "resultadoconsumação", assim entendido como a consumação material da prestação de serviços pelo prestador, ou como "resultado-utilidade", que é a utilidade gerada em decorrência da prestação de serviços em favor do contratante, o que significa dizer que mesmo sendo totalmente executado no exterior, se a fruição dos serviços ocorrer no Brasil, estará cofigurada a hipótese de incidência do PIS/COFINS-importação;

61. - A CIDE, tributo especial vocacionado à promoção de fins determinados, propicia a intervenção, por parte da União, no domínio econômico. Para tanto, é indispensável haver um liame entre a intervenção em determinado setor específico e as atividades dos destinatários da lei (referibilidade). A referibilidade possui várias acepções, podendo ser entendida como benefício econômico proporcionado aos que arcam com o ônus fiscal, bem como o liame entre a finalidade da contribuição e as atividades ou interesses dos sujeitos passivos (referibilidade como pertinência); 
62. - O STF afastou a necessidade de as contribuições interventivas proporcionarem benefícios aos contribuintes ao julgar constitucional a contribuição ao SEBRAE (RE $n^{\circ}$ 401.823), assim como o STJ (RESP n ${ }^{\circ}$ 770.451) afastou a necessidade de haver "liame referido" entre sujeitos passivos (que deveriam atuar no segmento sob intervenção) e o setor objeto da contribuição ao INCRA, tida como CIDE;

63. - A Lei $n^{\circ}$ 10.168/00 instituiu a CIDE na seara da Ciência e da Tecnologia, custeando o Programa de Estímulo à Interação Universidade-Empresa para o apoio à inovação com o intuito de estimular o desenvolvimento tecnológico brasileiro, mediante programas de pesquisa científica e tecnológica cooperativa entre universidades, centros de pesquisa e o setor produtivo;

64. - A finalidade da CIDE é o que determina e condiciona o seu espectro de incidência. A tecnologia foi qualificada como o fim a ser buscado com a exigência da contribuição dos detentores de licença de uso ou adquirentes de conhecimentos tecnológicos e dos que contratam a transferência de tecnologia com residentes e domiciliados no exterior;

65. - A ampliação da hipótese de incidência da contribuição pela Lei no 10.332/01 (art. $2^{\circ}$, $\S 2^{\circ}$, da Lei $\mathrm{n}^{\circ} 10.168 / 00$ ), que passou a alcançar as pessoas jurídicas que contratam serviços técnicos e de assistência administrativa e semelhantes prestados por residentes ou domiciliados no exterior, bem como as pessoas jurídicas que remetem royalties, a qualquer título, a beneficiários residentes ou domiciliados no exterior, deturpou a função da CIDE que passou a, equivocadamente, incidir sobre praticamente qualquer pagamento remetido ao exterior como contraprestação pela prestação de serviços, independentemente de envolver ou não a transferência de tecnologia;

66. - A CIDE-tecnologia não poderia ser exigida em conjunto com o PIS/COFINSimportação, em face da identidade de algumas materialidades e por ofender o princípio da não-discriminação previsto no art. $2^{\circ}$ do GATS (do qual o Brasil é signatário), aplicável ao comércio internacional, já que os serviços prestados por residentes nacionais não estão sujeitos à contribuição interventiva;

67. - A contribuição interventiva é um adicional do IRRF, porém inconstitucional já que a sua receita está vinculada a determinado fundo, o que afronta o art. 167, IV, da CF; 
68. - A concessão de licença de uso do programa não requer o fornecimento do códigofonte (tecnologia), pois se assim fosse, não se trataria de mera licença, mas de cessão (integral) de direitos patrimoniais de autor (“compra e venda");

69. - Ainda que os royalties a qualquer título configurem hipótese de incidência da contribuição interventiva (nos termos do art. $2^{\circ}, \S 2^{\circ}$, da Lei $n^{\circ} 10.168 / 00$ ), o legislador fez da remuneração pela licença de uso de software (sem transferência de tecnologia) uma hipótese de não-incidência da norma, quando paga diretamente ao autor da obra;

70. - Por meio da Portaria n ${ }^{\circ}$ 181/89, a União passou a exigir o IRRF, à alíquota de $25 \%$, sobre os pagamentos remetidos ao exterior como contraprestação pela aquisição dos direitos autorais de comercialização, distribuição e de uso de programas de computador. O Decreto-lei $\mathrm{n}^{\circ} 1.418 / 75$ diz respeito à tributação na fonte da contraprestação de determinados serviços (serviços técnicos, de assistência técnica, administrativa e semelhantes), enquanto a Lei $n^{\circ} 9.779 / 99$ grava com o IRRF todas as contraprestações por quaisquer serviços;

71. - Os rendimentos remetidos às pessoas físicas ou jurídicas residentes ou domiciliadas no exterior sofrem a incidência do IRRF da seguinte forma: (i) rendimentos em geral 15\%; (ii) os que remuneram prestação de serviços - 25\% (art. 685, II, “a”, do RIR/99); (iii) os decorrentes de prestação de serviços técnicos e de assistência técnica, administrativa e semelhantes - alíquota de 15\% (nos termos da Lei $\mathrm{n}^{\circ} 10.168 / 00$ ); (iv) os royalties a qualquer título - $15 \%$;

72. - O IRRF não incide sobre a remuneração enviada ao exterior como pagamento por licença de uso de software "de prateleira", pois a SRF entende que se trata de uma compra de mercadoria para revenda;

73. - Em relação ao software desenvolvido "sob encomenda" (em cópia única), a SRF posiciona-se favoravelmente à incidência do IRRF sobre os rendimentos conjugados remetidos ao exterior para pagar pela prestação de serviço e pela respectiva licença de uso (se for o caso), sob o argumento de que se tratam de royalties. A remuneração pelo uso, fruição, exploração de direitos autorais quando percebidos diretamente pelo autor da obra está excluída do conceito de royalty, nos termos do art. 22, da Lei nº 4.506/64; 
74. - A incidência do IR sobre a remuneração enviada ao exterior para pagar a prestação de serviços de elaboração de software "sob encomenda" configura invasão de competência tributária por incidir sobre mesma base de cálculo do ISS (preço do serviço);

75. - Nos termos do art. 43, do CTN, o imposto incide sobre a aquisição da disponibilidade econômica ou jurídica de renda e de proventos de qualquer natureza, assim entendidos como o acréscimo patrimonial ocorrido em um espaço de tempo. A exigência do IRRF sobre os rendimentos enviados ao não residente, prestador de serviços, é ilegal e inconstitucional por não incidir sobre acréscimo patrimonial, mas sobre rendimento bruto;

76. - O acréscimo patrimonial só é aferido mediante a contraposição de todas as receitas e rendimentos e de todos os custos e despesas, auferidos em um determinado período. Assim, a renda tributável ("o lucro") é o resultado algébrico positivo dessa contraposição de receitas e despesas e somente ocorrerá ao final de determinado período e de acordo com as normas do país de residência; e,

77. - A exigência do IRRF sobre o rendimento bruto impede a aplicação do princípio da capacidade contributiva (art. $145, \S 1^{\circ}$, da CF), pois ao proceder-se desta maneira não se prestigia a incidência do imposto sobre signos presuntivos de riqueza, de forma graduada e de acordo com a capacidade econômica do contribuinte, tornando o IR, que deveria ser pessoal, em imposto real. 


\section{REFERÊNCIA BIBLIOGRÁFICA}

ALBUQUERQUE, Roberto Chacon de. A Propriedade Informática. Campinas: Russell, 2006.

ALVES, Anna Emilia Cordelli. ISS - Aspectos Relevantes Decorrentes da Análise do Artigo $1^{\circ}$ da Lei Complementar $n^{\circ} 116$, de 31 de julho de 2003. Revista Dialética de Direito Tributário, no 99. São Paulo: Dialética, 2003.

ARAUJO, Ana Clarissa Masuko dos Santos. ICMS no E-commerce e o Protocolo ICMS 21/2011 - Permanecem as Inconstitucionalidades. Revista Dialética de Direito Tributário, no 193. São Paulo: Dialética, 2011.

ARAÚJO, Gisele Ferreira. A Tutela Internacional do Direito do Autor. In PIMENTA, Eduardo Salles (coord.). Direitos Autorais - Estudos em homenagem a Otávio Afonso dos Santos. São Paulo: RT, 2007.

ASCENSÃO, José de Oliveira. Direito Autoral. Rio de Janeiro: Renovar, 2007.

ATALIBA, Geraldo. Hipótese de Incidência Tributária. São Paulo: Malheiros, 2001. 1968. Sistema Constitucional Tributário Brasileiro. São Paulo: Revista dos Tribunais, ICM sobre a importação de bens de capital para uso do importador. Revista Forense, vol. 250. 1975.

ÁVILA, Humberto. Teoria dos Princípios, da definição à ampliação dos princípios jurídicos. São Paulo: Malheiros, 2010.

Imposto sobre a prestação de serviços de qualquer natureza - Exportação de Serviços - Lei Complementar no 116/03 - Isenção: requisitos e alcance - Conceito de "desenvolvimento" de serviço e "verificação" do seu resultado. Revista Dialética de Direito Tributário, no 134. São Paulo: Dialética, 2006.

Imposto sobre serviços de qualquer natureza - ISS. Normas constitucionais aplicáveis. Precedentes do Supremo Tribunal Federal. Hipótese de Incidência, Base de Cálculo e Local da Prestação, Leasing Financeiro: Análise da Incidência, Revista Dialética de Direito Tributário, no 122. São Paulo: Dialética, 2005.

_. Sistema Constitucional Tributário. São Paulo: Saraiva, 2006.

- Regra-matriz versus princípios. Direito Tributário-Homenagem a Paulo de Barros Carvalho. São Paulo: Quartier Latin, 2008.

BALEEIRO, Aliomar. Direito Tributário Brasileiro. 11 ${ }^{\mathrm{a}}$ ed. Rio de Janeiro: Forense, 2001. 
2006.

Limitações Constitucionais ao Poder de Tributar. Rio de Janeiro: Forense,

BAPTISTA, Marcelo Caron. ISS do texto à norma - Doutrina e jurisprudência da EC 18/65 à LC 116/03. São Paulo: Quartier Latin, 2007.

BARRETO, Aires Fernandino. Regime Jurídico-tributário da Chamada Conectividade. Revista Dialética de Direito Tributário no 160. Dialética: São Paulo, 2009.

ISS na Constituição e na Lei. São Paulo: Dialética, 2009.

ISS - Não incidência sobre atividades desenvolvidas em águas marítimas. Revista Dialética de Direito Tributário, $\mathbf{n}^{0}$ 200. São Paulo: Dialética, 2012.

ISS - Não incidência sobre a importação de serviços. Revista Dialética de Direito Tributário, no 201. São Paulo: Dialética, 2012.

ICMS e ISS - Estremação da Incidência. Revista Dialética de Direito Tributário no 71. São Paulo: Dialética, 2001.

BARRETO, Paulo Ayres. Contribuições - Regime Jurídico, Destinação e Controle. São Paulo: Noeses, 2006.

O Imposto sobre a Renda e os Preços de Transferências. Dissertação de Mestrado apresentada à Faculdade de Direito da Pontifícia Universidade Católica de São Paulo, 1999.

BECKER, Alfredo Augusto. Teoria Geral do Direito Tributário. São Paulo: Noeses, 2007.

BEVILAQUA, Clovis. Direito das Obrigações. Rio de Janeiro: Paulo de Azevedo. $8^{\text {a }}$ Ed., 1954.

BIFANO, Elidie Palma. O Negócio Eletrônico e o Sistema Tributário Brasileiro. São Paulo: Quartier Latin, 2004.

BITTAR, Carlos Alberto (coord.). Contratos de Comercialização de "Software". In Novos Contratos Empresariais. São Paulo: RT, 1990.

BITTAR, Carlos Alberto e Filho; BITTAR, Carlos Alberto. Tutela dos Direitos da Personalidade e dos Direitos Autorais nas Atividades Empresariais. São Paulo: RT, 2002.

BITTAR, Carlos Alberto. Direito de Autor. São Paulo: Forense Universitária, 2004.

BORGES, José Souto Maior. Lei Complementar Tributária. São Paulo: Universidade Católica, 1975.

. O Fato Gerador do I.C.M. e os Estabelecimentos Autônomos. Revista de Direito Administrativo, vol. 103. FGV-Instituto de Documentação: Rio de Janeiro, 1971. 
ICM sobre a importação de bens de capital para uso do importador. Revista Forense, vol. 250. Rio de Janeiro: Forense, 1975.

- Inconstitucionalidade e ilegalidade da cobrança do ISS sobre contratos de assistência médico-hospitalar. Revista de Direito Tributário, $\mathbf{n}^{\mathbf{0}} 38$. São Paulo: RT.

BRANCHER, Paulo Marcos Rodrigues. Contratos de Software. Florianópolis: Visual Books, 2003.

BRITO, Edvaldo, Software: ICMS, ISS ou Imunidade Tributária?. Revista Dialética de Direito Tributário, no 5. São Paulo: Dialética, 1996.

CABRAL, Plinio. A Nova Lei de Direitos Autorais - Comentários. São Paulo: Harbra, 2003.

CANTO, Gilberto de Ulhôa. Causa da Obrigação Tributária. Temas de Direito Tributário. Rio de Janeiro: Alba, 1963.

CARRAZZA, Roque Antonio. Curso de Direito Constitucional Tributário. $16^{\mathrm{a}}$ ed. São Paulo: Malheiros, 2006.

ICMS. São Paulo: Malheiros, 2009.

CARVALHO. Fabio Junqueira; MURGEL, Maria Inês. A Contribuição de Intervenção no Domínio Econômico sobre Royalties e a Análise do Crédito. In ROCHA, Valdir de Oliveira. Contribuições de Intervenção no Domínio Econômico e Figuras Afins. São Paulo: Dialética, 2001.

CARVALHO. Paulo de Barros. Teoria da Norma Tributária. $3^{\text {a }}$ ed. São Paulo: Max Limonad, 1998. 1998.

Direito Tributário - Fundamentos Jurídicos da Incidência. São Paulo: Saraiva,

Curso de Direito Tributário. 12ª ed. São Paulo: Saraiva, 1999.

Direito Tributário Linguagem e Método. São Paulo: Noeses, 2009.

- Regra matriz do ICM. Tese de Livre-Docência em Direito Tributário apresentada à Faculdade de Direito da Pontifícia Universidade Católica de São Paulo, 1981.

CATÃO, Marcos André Vinhas. Incompatibilidade da Contribuição de Intervenção no Domínio Econômico CIDE-Tecnologia (Lei $\mathrm{n}^{\circ}$ 10.168/00), a partir da Instituição do PIS/COFINS - Importação/Serviços (Lei no 10.865/04). Violação das Regras do GATT e GATS. Revista Dialética de Direito Tributário, no 115. São Paulo: Dialética, 2005.

CEZAROTI, Guilherme. A incidência do ICMS sobre as operações internas e interestaduais de vendas de mercadorias realizadas eletronicamente. Dissertação de Mestrado apresentada à Faculdade de Direito da Universidade de São Paulo, 2004. 
Breves considerações a respeito da incidência do ICMS. In SCHOUERI, Luís Eduardo (coord.), Internet - O Direito na Era Virtual. Rio de Janeiro: Forense, 2001. CHIESA, Clélio. Competência para tributar as operações com programas de computador (softwares). Campos, Djalma de (coord.), Revista Tributária e de Finanças Públicas, $\mathbf{n}^{\circ}$ 36. São Paulo: Revista dos Tribunais, 2001.

. Inconstitucionalidades da LC $n^{\circ} 116 / 03$. In Imposto sobre Serviços - ISS na Lei Complementar no 116/03 e na Constituição. São Paulo: Manole, 2004.

COÊLHO, Sacha Calmon Navarro; MOREIRA, André Mendes. Inconstitucionalidades da contribuição de intervenção no domínio econômico ao exterior - CIDE royalties. Revista Dialética de Direito Tributário, no 89. São Paulo: Dialética, 2003.

COÊLHO, Sacha Calmon Navarro. O Controle da Constitucionalidade das Leis e do Poder de Tributar na Constituição de 1988. $3^{\text {a }}$ ed. Belo Horizonte: Del Rey, 1999.

- Venda de refeições a empresas que as fornecem a seus empregados no bojo do programa de alimentação do trabalhador (PAT) - Inexistência de operação de saída de mercadoria - Desnecessidade de recolhimento do ICMS-ST pelo fabricante. Revista Dialética de Direito Tributário, no 129. São Paulo: Dialética, 2006.

CONTI, José Mauricio. Sistema Constitucional Tributário Interpretado pelos Tribunais. São Paulo: Oliveira Mendes, 1997.

COSTA, Alcides Jorge. ICM na Constituição e na Lei Complementar. São Paulo: Resenha Tributária, 1978.

ICM - Estrutura na Constituição e na Lei Complementar, Tese de livre-docência apresentada à Faculdade de Direito da Universidade de São Paulo, 1977.

ICMS - Importação - Máquina para uso em processo produtivo - Transferência para outro estabelecimento da empresa - Significado da expressão "Bem do Ativo Fixo", Revista de Estudos Tributários, vol. 15. Síntese: São Paulo, 2000.

CRIVELLI, Ivana Go. A Regulamentação da Contratação de Direitos Autorais. In PIMENTA, Eduardo Salles (coord.). Direitos Autorais - Estudos em homenagem a Otávio Afonso dos Santos. São Paulo: RT, 2007.

DERZI, Misabel de Abreu Machado. Direito Tributário, Direito Penal e Tipo. São Paulo: Revista dos Tribunais, 1988.

DINIZ, Maria Helena. Código Civil Anotado. 10ª ed. São Paulo: Saraiva, 2004.

FERRAZ, Roberto (coord.). Princípios e Limites da Tributação. São Paulo: Quartier Latin, 2005.

GERMANO, Livia De Carli, A tributação de músicas e vídeos comercializados na internet e entregues via download e streaming. In OLIVEIRA, Ricardo Mariz; SCHOUERI, Luís Eduardo; ZILVETI, Fernando Aurelio (coord.). Revista de Direito Atual, v. 27. São Paulo: Dialética, 2012. 
GOMES, Orlando. Contratos. Rio de Janeiro: Forense, $8^{\text {a }}$ ed. 1986.

GONÇALVES, Renato Lacerda de Lima. A Tributação do Software no Brasil. São Paulo: Quartier Latin, 2005.

GRECCO, Marco Aurélio (coord.). Contribuições de Intervenção no Domínio Econômico e Figuras Afins. São Paulo: Dialética, 2001.

. Contribuições (Uma Figura “Sui Generis”). São Paulo: Dialética, 2000.

Contribuição de Intervenção Econômica sobre Royalties, Revista Dialética de

Direito Tributário, no 99. São Paulo: Dialética, 2003.

Internet e Direito. São Paulo: Dialética, 2000.

JÚNIOR, Helio Alberto Bellintani. Contrato de licenciamento de uso dos programas de computador destinados à gestão empresarial. Dissertação de mestrado apresentada à Pontifícia Universidade Católica de São Paulo, 2003.

JUNIOR, Hugo Orrico. Pirataria de Software. São Paulo: MM Livros, 2004.

JÚNIOR, Tércio Sampaio Ferraz. Livro Eletrônico e Imunidade Tributária, Cadernos de Direito Tributário e de Finanças Públicas, vol. 22. 1998.

KRAKOWIAK, Leo; KRAKOWIAK, Ricardo. Tributação aduaneira e problemas jurídicos decorrentes da informatização do comércio exterior. In GRECO, Marco Aurélio; MARTINS, Ives Gandra da Silva (coord.). Direito e Internet. São Paulo: Revista dos Tribunais, 2001.

LARENZ, Karl. Metodologia da Ciência do Direito. Lisboa: Fundação Calouste Gulbenkian, 2009.

LIMA, José Vieira. IPI - A regra-matriz de incidência - texto e contexto. Curitiba: Juruá, 1993.

LIMA, Sebastião de Oliveira. O fato gerador do imposto de importação no direito brasileiro. São Paulo: Resenha Tributária, 1981.

LINS, Bernardo Felipe Estellita; LOPES, Cristiano Aguiar; NAZARENO, Cláudio (coord.). O Mercado de Software no Brasil: Problemas Institucionais e Fiscais. Brasília: Câmara dos Deputados, Coordenação de Publicações, 2007.

LUNARDELLI, Pedro Guilherme Accorsi. Tributação na internet, Revista Dialética de Direito Tributário, São Paulo, no 59. São Paulo: Dialética, 2000.

MACEDO, Alberto. O critério espacial do ISS nas prestações de serviço intermunicipais. BERGAMINI, Adolpho e BOMFIM, Diego Marcel (coord.). In Comentários à lei complementar no 116/03 - De advogados para advogados. São Paulo: MP Editora, 2009. 
ISS e PIS-COFINS-Importação - Critérios Espacial e Pessoal na Prestação Internacional de Serviços, Revista Dialética de Direito Tributário, $\mathbf{n}^{0}$ 187. São Paulo: Dialética, 2011.

MACHADO, Hugo de Brito. Aspectos fundamentais do ICMS. São Paulo: Dialética, 1997.

In MARTINS, Ives Gandra da Silva (coord.). Tributação na Internet. São Paulo: Revista dos Tribunais, 2001.

Curso de Direito Tributário. São Paulo: Malheiros, 2008.

. O ISS e a Locação ou Cessão de Direito de Uso. In ROCHA, Valdir de Oliveira (coord.), O ISS e a LC 116/03. São Paulo: Dialética, 2003.

MANSO, Eduardo Vieira. Contratos de Direito Autoral. São Paulo: RT, 1989.

MARCHI, Eduardo C. Silveira. Guia da Metodologia Jurídica. $2^{a}$ ed. São Paulo: Saraiva, 2009.

MARTINS, Ives Gandra. O Sistema Tributário na Constituição. $6^{\mathrm{a}}$ ed. São Paulo: Saraiva, 2007.

MARTINS, Ives Gandra da Silva; RODRIGUES, Marilene Talarico Martins. Aspectos relevantes do ISS. Revista Dialética de Direito Tributário, $\mathbf{n}^{\circ}$ 182. São Paulo: Dialética, 2010.

MELLO, José Eduardo Soares de. ICMS, Teoria e Prática. São Paulo: Dialética, 2002.

Inconstitucionalidades da LC $n^{\circ} 116 / 03$. In Imposto sobre Serviços - ISS na Lei Complementar no 116/03 e na Constituição. São Paulo: Manole, 2004.

MENDONÇA, José Xavier Carvalho de. Tratado de Direito Comercial Brasileiro, vol. V, $1^{\text {a }}$ parte. São Paulo: Freitas Bastos, 1946.

MORAES, Bernardo Ribeiro de. Doutrina e Prática do ISS. São Paulo: RT, 1978.

Imposto Sobre Serviços de Qualquer Natureza. in MARTINS, Ives Gandra da Silva (coord.). Curso de Direito Tributário. Belém: CEJUP, 1997.

As operações de leasing diante do ICMS e do ISSQN. In ROCHA, Valdir de Oliveira (coord.). O ICMS, a LC 87/96 e questões jurídicas atuais. São Paulo: Dialética, 1997.

MOSQUERA, Roberto Quiroga. Renda e Proventos de Qualquer Natureza. O Imposto e seu Conceito Constitucional. São Paulo: Dialética, São Paulo: Dialética, 1996.

MOURA, Fabio Clansen de. A relevância da fonte de pagamento em relação à incidência do ISS sobre operações internacionais de serviços, Revista de Direito Tributário Internacional, $\mathbf{n}^{\mathbf{0}}$ 7. Quartier Latin: São Paulo, 2007. 
MOUSSALLEM, Tárek Moysés. Classificação dos Tributos - Uma visão analítica. In IV Congresso Nacional de Estudos Tributários - Tributação e Processo. São Paulo: Noeses, 2007.

NETO, Miguel Hilú. Imposto sobre importações e bens virtuais. In SCHOUERI, Luís Eduardo (coord.). Internet - O Direito na Era Virtual. Rio de Janeiro: Forense, 2001.

NETTO, José Carlos da Costa. Direito Autoral no Brasil. São Paulo: FDT, 2008.

NOGUEIRA, Ruy Barbosa. Direito Financeiro (Curso de Direito Tributário). São Paulo: José Bushatsky Editor, 1964.

Curso de Direito Tributário.São Paulo: Saraiva, 1995.

OLIVEIRA, Ricardo Mariz de. Operações relacionadas com imóveis e empresas construtoras. Revista Dialética de Direito Tributário, nº 6. São Paulo: Dialética, 1996.

. Fundamentos do Imposto de Renda, São Paulo: Quartier Latin, 2008.

PAESANI, Liliana Minardi. Direito de Informática. São Paulo: Atlas, 1999.

PANDOLFO, Rafael. Tributação do Comércio Eletrônico: Análise da Incidência do ICMS. In Revista de Estudos Tributários no 33. Síntese: São Paulo, 2003.

PAUlSEN, Leandro; VELlOSO, Andrei Pitten. Contribuições - Teoria geral Contribuições em espécies. Porto Alegre: Livraria do Advogado, 2010.

PEREIRA, Caio Mário da Silva. Instituições de Direito Civil, v.3. Rio de Janeiro: Forense. 1978, p. 33.

PIMENTA, Paulo Roberto Lyrio. Cofins-importação e PIS/PASEP-importação: Contribuições interventivas inconstitucionais. Revista Dialética de Direito Tributário, $\mathbf{n}^{\mathbf{o}}$ 113. São Paulo: Dialética, 2005.

ROCHA, Sergio André. O resultado do serviço como elemento da regra de incidência do PIS/COFINS-Importação e da regra exonerativa do ISS sobre exportações. Revista Dialética de Direito Tributário, $\mathbf{n}^{0}$ 155. São Paulo: Dialética, 2008.

RONCAGLIA, Marcelo Marques. O ISS e a Importação e Exportação de Serviços. Revista Dialética de Direito Tributário, n 129. São Paulo: Dialética, 2006.

ROTHMANN, Gerd Willi. Tributação Internacional sem Sujeito Passivo: Uma Nova Modalidade de Imposto de Renda sobre Ganhos de Capital?. In ROCHA, Valdir de Oliveira (coord.). Grandes Questões Atuais do Direito Tributário, 10 ${ }^{\circ}$ v. São Paulo: Dialética, 2006.

Problemas de Qualificação na Aplicação das Convenções contra a Bitributação Internacional. Revista Dialética de Direito Tributário, no 76. São Paulo: Dialética, 2002. 
O Princípio da Legalidade Tributária. Revista de Direito Mercantil Industrial Econômico Financeiro, no 8. São Paulo: Revista dos Tribunais, 1972.

. A guerra fiscal dos Estados na (des)ordem tributária e econômica da federação. In CARVALHO, Antonio augusto Silva Pereira de; FERNÁNDEZ, German Alejandro San Martín (coord.). Direito Tributário - Estudos em homenagem a José Eduardo Monteiro de Barros. São Paulo: MP, 2010.

A bitributação internacional. In DÓRIA, Antonio Roberto Sampaio; ROTHMANN, Gerd Willi. Temas Fundamentais do Direito Tributário Atual. Belém: CEJUP, 1983.

- Tributação, Sonegação e Livre Concorrência. In FERRAZ, Roberto (coord.). Princípios e Limites da Tributação 2 - Os Princípios da Ordem Econômica e a Tributação. São Paulo: Quartier Latin, 2009.

Inconstitucionalidade múltipla na tributação da importação de serviços Réquiem ou catarse do sistema tributário nacional?, Tese de Livre-Docência apresentada à Faculdade de Direito da Universidade de São Paulo, 2010.

SANTI, Eurico Marcos Diniz de; PEIXOTO, Daniel Monteiro. PIS e COFINS na importação, competência: entre regras e princípio. Revista Dialética de Direito Tributário, no 121. São Paulo: Dialética, 2005.

SANTOS, Manoel J. Pereira dos. Licença de Software, Revista da Associação Brasileira de Propriedade Intelectual $\mathbf{n}^{0} 25$.

SANTOS, Manuella Silva dos. Direitos autoral na era digital: Impactos, controvérsias e possíveis soluções. Dissertação de Mestrado apresentada à Faculdade de Direito da Pontifícia Universidade Católica de São Paulo, 2008.

SCHOUERI, Luis Eduardo e CEZAROTI, Guilherme. A Cide-royalties e as Remessas por Licença de Distribuição e Comercialização de Programas de Computador. Revista Dialética de Direito Tributário, no 130. São Paulo: Dialética, 2006.

SCHOUERI, Luis Eduardo (coord.). Direito Tributário, Homenagem a Paulo de Barros Carvalho. São Paulo: Quartier Latin, 2008.

Forense, 2005.

Normas Tributárias Indutoras e Intervenção Econômica. Rio de Janeiro: . Discriminação de Competências e Competência Residual. In Direito Tributário: Estudos em Homenagem a Brandão Machado. São Paulo: Dialética, 1998.

ISS sobre a Importação de Serviços do Exterior. Revista Dialética de Direito Tributário, no 100. São Paulo: Dialética, 2004.

SILVA, José Afonso da. Curso de Direito Constitucional Positivo. $34^{\text {a }}$ Ed., São Paulo: Malheiros, 2011. 
SILVA, Sérgio André R. G. da. Considerações acerca da incidência do ISS sobre serviços prestados no exterior. Revista Dialética de Direito Tributário, $n^{0}$ 104. São Paulo: Dialética, 2004.

SIQUEIRA, Ana Paula Cotrim. O direito autoral dos programas de computador. Dissertação de Mestrado apresentada à Faculdade de Direito da Pontifícia Universidade Católica de São Paulo, 2008.

SOUZA, Carlos Fernando Mathias, O Comércio Internacional e os Direitos Conexos: o TRIPS. In PIMENTA, Eduardo Salles (coord.). Direitos Autorais - Estudos em homenagem a Otávio Afonso dos Santos. São Paulo: RT, 2007.

TAVOLARO, Agostinho Toffoli; MACHADO, Brandão; MARTINS, Ives Gandra da Silva (coord.). Princípios Tributários no Direito Brasileiro Comparado, Estudos em Homenagem a Gilberto de Ulhôa Canto. Rio de Janeiro: Forense, 1988.

TÔRRES, Heleno Taveira (coord.). Comércio Internacional e Tributação. São Paulo: Quartier Latin, 2005.

A Hipótese do ICMS sobre Operações Mercantis na Constituição e a Solução dos Conflitos Normativos. In SCHOUERI, Luís Eduardo (coord.). Direito Tributário Homenagem a Paulo de Barros Carvalho, São Paulo: Quartier Latin, 2008.

Prestações de serviços provenientes do exterior ou cuja prestação se tenha iniciado no exterior. In Imposto sobre Serviços - ISS na Lei Complementar no 116/03 e na Constituição. São Paulo: Manole, 2004.

Conceito de estabelecimento como critério de solução de conflitos no ISS. Fiscosoft. http://www.fiscosoft.com.br/a/5tvd/conceito-de-estabelecimento-como-criteriode-solucao-de-conflitos-no-iss-heleno-taveira-torres, acesso em: 09.07.2012.

TORRES, Ricardo Lobo. Curso de Direito Financeiro e Tributário. Rio de Janeiro: Renovar, 2005.

UCKMAR, Victor. Princípios Comuns de Direito Constitucional Tributário. São Paulo: Revista dos Tribunais, 1976.

VELLOSO, Andrei Pitten. Conceitos e competências Tributárias. São Paulo: Dialética, 2005.

VENOSA, Silvio de Salvo. Teoria Geral das Obrigações e Teoria Geral dos Contratos. São Paulo: Atlas, 2003.

Direito Civil: Contratos em Espécie, no 3. São Paulo: Atlas, 2005.

VILANOVA, Lourival. As Estruturas Lógicas e o Sistema do Direito Positivo. São Paulo: Max Limonad, 1997. 
WACHOWICZ, Marcos, Revolução Tecnológica e Propriedade Intelectual. In PIMENTA, Eduardo Salles (coord.), Direitos Autorais - Estudos em homenagem a Otávio Afonso dos Santos. São Paulo: RT, 2007.

WALD, Arnoldo. Base de cálculo para a cobrança do ICM, nas transferências de armazéns para filiais da mesma empresa. Revista de Direito Público, no 19.

WILlington, João; OliVEIRA, Jaury N. de. A Nova Lei Brasileira de Direitos Autorais. Rio de Janeiro: Lumen Juris, 2002.

XAVIER, Alberto. Direito Tributário Internacional do Brasil. $6^{a}$ ed. Rio de Janeiro: Forense, 2005.

. Os Princípios da Legalidade e da Tipicidade da Tributação. São Paulo: Revista dos Tribunais, 1978. 